\title{
Dialectic of Gloom
}

How the press survived the Great Recession of 2008, after slashing its wrists and writing its own obituary

by

Brian Gorman, M.J.

\begin{abstract}
A thesis submitted
to the Faculty of Graduate and Postdoctoral Affairs

in partial fulfillment of the requirements

for the degree of
\end{abstract}

Doctor of Philosophy

in

Communication Studies

Carleton University

Ottawa, Ontario 
Library and Archives

Canada

Published Heritage

Branch

395 Wellington Street

Ottawa ON K1A ON4

Canada
Bibliothèque et

Archives Canada

Direction du

Patrimoine de l'édition

395 , rue Wellington

Ottawa ON K1A ON4

Canada
Your file Votre référence

ISBN: $978-0-494-94220-8$

Our file Notre référence

ISBN: $978-0-494-94220-8$
NOTICE:

The author has granted a nonexclusive license allowing Library and Archives Canada to reproduce, publish, archive, preserve, conserve, communicate to the public by telecommunication or on the Internet, loan, distrbute and sell theses worldwide, for commercial or noncommercial purposes, in microform, paper, electronic and/or any other formats.

The author retains copyright ownership and moral rights in this thesis. Neither the thesis nor substantial extracts from it may be printed or otherwise reproduced without the author's permission.
AVIS:

L'auteur a accordé une licence non exclusive permettant à la Bibliothèque et Archives Canada de reproduire, publier, archiver, sauvegarder, conserver, transmettre au public par télécommunication ou par l'Internet, prêter, distribuer et vendre des thèses partout dans le monde, à des fins commerciales ou autres, sur support microforme, papier, électronique et/ou autres formats.

L'auteur conserve la propriété du droit d'auteur et des droits moraux qui protege cette thèse. $\mathrm{Ni}$ la thèse ni des extraits substantiels de celle-ci ne doivent être imprimés ou autrement reproduits sans son autorisation.
In compliance with the Canadian Privacy Act some supporting forms may have been removed from this thesis.

While these forms may be included in the document page count, their removal does not represent any loss of content from the thesis.
Conformément à la loi canadienne sur la protection de la vie privée, quelques formulaires secondaires ont été enlevés de cette thèse.

Bien que ces formulaires aient inclus dans la pagination, il n'y aura aucun contenu manquant. 


\section{Abstract}

THE 'DEATH of news' panic that began in 2008 has painted a portrait of a business rendered obsolete by digital technology and being forced into extinction by a "broken business model." However, a closer look at the press coverage reveals more complex circumstances, which must be placed in the context of 50 years of media theory to be appreciated. Unfortunately, as several observers have noted, the discourse has been dominated by a point of view that is business-focused and Western-centric. As a result, the conversation has excluded such constituencies, as small-city dailies, community newspapers, alternative publications, and the business in such emerging nations as India, China, Argentina, Brazil and sub-Saharan Africa, where daily journalism is surviving, and in some cases booming.

Another characteristic of the conversation is that it ignores many years of criticism, as if there is an unspoken assumption that the "broken business model" has absolved the industry of such well documented shortcomings as: a tendency to practice 'safe' journalism that appeals to the affluent and provides a pleasant climate for advertising; a preoccupation with the rich and the powerful; the abandonment of investigative reporting. At the same time, the economic situation has, as Tina Brown put it, provided timely "air cover" for an industry that has long been run by corporations that have financed acquisitions with debt, while tying themselves to shareholder expectations of unrealistic profits - to the point that many profitable newspapers were forced by heavily indebted parent companies into rounds of layoffs that undermined the brands that were supposed to carry them into the digital age. 
New technology has presented large challenges for mainstream news businesses - not the least of which is the way the Internet has revolutionized advertising. Yet, the newspaper industry has largely been the author of much, if not most, of it own misfortune.

Finally, because of the focus on industrial imperatives, the conversation about the great promise of the new technology in terms of the practice and craft of journalism has been reduced almost to a sideshow, when it could be argued that it should be at the centre of the discussion. 


\section{Acknowledgements}

FIRST, I have to thank my thesis advisor, Dr. Christopher Dornan, who had to put up with my ramblings and ravings through two theses-a master's and then a doctoral dissertation. If that's not effort above and beyond the call of duty, I don't know what is. I would also like to offer my gratitude to the other two members of my editorial board, Drs. Michel Dorland and André Turcotte, who also taught the two sections of the core seminar of the doctoral program the year I entered it. Their teaching had more to do with my continuing in the program than they could know. Thanks also to Drs. Enn Raudsepp and Peter Hodgins for taking time to sit as examiners at my defence.

If it had not been for my wife, Diane, I never would have started this journey. Her encouragement and support helped me through when I would have gladly turned to something else, and I am eternally grateful. I also thank my children, Patrick, Connor, Sean and Katie, whose tolerance of my weird hobby was almost as strong as their bemusement. A special thank-you goes to Connor for his patience and effort in getting this massive thing through the printer, twice, and to Katie for delivering it.

I'd also like to thank the unsung heroes of the Carleton University School of Journalism and Communication, administrative assistants Frida Ann Choueiri, Carole Craswell, and Coleen Kornelson.

And finally, though it almost seems redundant considering how ruthlessly I have ransacked their works, I need to say thank-you to the giants upon whose shoulders I have tried to stand. 


\section{Table of contents}

Introduction Postmodern times

Chapter 1 Language \& power

25

Chapter 2 Steel, ink, flesh \& money

68

Chapter 3 Cries, criticism, curses \& complaints

Chapter 4 Dialectic of gloom: business

162

Chapter 5 Dialectic of gloom: technology

213

Chapter 6 Dialectic of gloom: craft 260

Conclusion Post-postmodern times 306 


\section{Introduction Postmodern times}

ALTHOUGH I am neither an expert in nor an aficionado of the Frankfurt School, I chose - respectfully and playfully - to name this thesis after Max Horkheimer's and Theodor Adorno's Dialectic of Enlightenment for a number of reasons, not the least of which is that it's a guaranteed attention grabber.

My desktop dictionary defines "dialectic" as "the art of investigating or discussing the truth of opinions." Given the amount of opinion about the newspaper business that has been flowing over the past couple of years, this seems appropriate for an effort to sift through it and make sense of it. Also, the Dialectic of Enlightenment poses the question of whether "enlightenment, in the service of the present, is turning itself into an outright deception of the masses" (2002: 34). That book deals with myth, and how enlightenment has reverted, or been converted, to myth. It asks how it could be that a world so enlightened in science and commerce can be so benighted in ethics, morality, culture and intellectual freedom, and examines how the illusion of intellectual freedom can be employed as a means of enslavement. As we see in the first three chapters of this thesis, these themes play important roles in much media criticism. Also, because it is an exploration of mystification, or gloom, the Dialectic of Enlightenment is a somewhat ironic title. Here, I hope to produce a discussion about gloom that will be as much an exploration of enlightenment. Finally, even the misuse of the word "dialectic" as referring to "dialect" is useful, because much of what follows deals with a specialized 
professional culture and its language of despair.

ONE OF the more dramatic aspects of the economic crisis that began in 2008 was what amounted to a prolonged and very noisy nervous breakdown on the part of the so-called mainstream media. This has yet to subside, though it has quieted down considerably. Often hyperbolic reportage on and analysis of the business has predicted that major cities would find themselves without newspapers, and that the old "gatekeeper" culture of the mainstream media would be swept aside by a new, free, "citizen" journalism. Readers and viewers were abandoning newspapers and television - or, at least, young desirable ones were - so advertisers were turning away from these "dying" media. At one extreme, observers conjured up visions of a democracy seized by a sudden inability to speak clearly to itself, a civil society transformed into a marketing culture, and a politics of polarization, atomization and alienation. At the other, there were utopian predictions that a wired citizenry would rise up and replace the old media with a new, conversational, fully participatory wikijournalism, in which everyone could be reporter, editor and publisher, and information would be collected and shaped by the people who consume it.

As one observer pointed out, there is a distinct "Manichean" tone to most of the conversation (Franklin, 2008): print is dead; long live digital media. Yet even a casual examination of the discourse reveals a maze of contradictions, generalizations and highly suspect conclusions. Many of the stories simply outline the financial struggles of several large media companies and apply that information to the newspaper industry at large - and ignore data in other stories, showing smaller 
newspapers and individual holdings of large media companies turning a profit, and foreign newspaper industries thriving. In some cases, stories contradict their own headlines. For example, one piece describes a generation that has turned away from print and to the Internet, yet contains figures that a) indicate more young people than before are reading newspapers, yet not as many as are getting news online, and b) most are getting news online from newspaper web sites or from newspapers through aggregators (Kawamoto, 2009).

Similarly, as Robert McChesney and John Nichols have pointed out, the debate over the future of the news business "has, for the most part, been presented as a matter of mechanics and ledgers rather than one of turmoil of journalists and danger for democracy" (2010: 19). The commentary and reportage over the four years in question provide considerable support for that, as well as a strange and often solipsistic historical amnesia. The crises of the recession are rarely if ever taken as being part of a longstanding set of financial problems involving overextended parent companies, debt, cost cutting and a consequent erosion of quality. It seems logical that all of this needs to be taken into account if you want to talk about "perfect storms," "broken business models" and fleeing audiences.

By harking back to a tradition of media criticism, and analysing a mass of the news and commentary about the industry that has been published over the past few years, it can be demonstrated that most of the challenges facing journalism predate the Internet by at least a decade, and some by more than 50 years. The current fixation on "mechanics and ledgers" obscures a longstanding and ongoing set of issues, and the story is much more complex, less Manichean and perhaps more hopeful than much of the commentary might lead us to believe. 
At its core, this thesis is an extension of a central discourse about the public and the news media, and their relationship in a functioning democracy, which has crystallized around some of the writings of Walter Lippmann and John Dewey: the questions of how involved in the democratic project we can expect the citizenry to be, and to what extent and in what ways the news media can be expected to advance this cause. By necessity, that involves addressing a set of questions that have dominated the recent study of journalism:

- To what extent is a media company a private enterprise, and to what extent is it a public trust?

- Is journalism an art, a business, a public service, or all of the above?

- Is it realistic to expect the news media to act as an agent for the democratic project?

- Should journalists, as individual craftspeople, be deployed as agents for any political, cultural or financial project?

- Is journalism primarily a cultural activity?

- How can the business, artistic and political aspects of journalism be reconciled?

To this, we could add a question that has become a recurring refrain in the age of online discourse: Are the traditional news media still a necessary component of the Public Sphere?

As well as Lippmann and Dewey, I will be looking for historical context to a variety of 20th century media and culture critics, and a selection of their predecessors, such as John Milton, Thomas Hobbes and Edmund Burke, to map out the concepts of 
free speech and public opinion. In the 20th century, this includes two thinkers who have taken on the roles of direct descendants of Lippmann and Dewey: respectively, Michael Schudson and James Carey. For perspective, I will also survey writings on culture and communication by Raymond Williams, Jurgen Habermas and Antonio Gramsci, as well as a number of recent news-media critics, such as Jay Rosen, Clay Shirky, Mark Deuze, Ben Bagdikian and Doug Underwood. Through them, I will explore the concepts of the newspaper as an instrument of public policy and as a business, and the concepts of public opinion and Public Sphere that have evolved over the decades. Also, through the writing of journalists and commentators - such as G. Stuart Adam, Eric Alterman, Joan Didion, Pippa Norris, and Tom Wolfe-l will look at the proposition that journalism, as G. Stuart Adam wrote, "can be and often is an art form," the study of which "has been dominated too long by the social sciences" (2006: 344-345), and survey some of the main criticisms and commonly perceived problems with journalism at the end of the 20 th century and the beginning of the 21 st.

THERE IS much to suggest that the news business suffers rather then benefits from what Schudson calls "a creeping desire to define journalism normatively, as a field with a mission" (2003: 14). One of the most powerful expressions of that "creeping desire" was the Four Theories of the Press, a surprisingly influential work-given its slimness of size and thought - that took a central place in much postwar thinking about the role of the news media in a modern society. Its most influential section, "The Social Responsibility Theory," was a direct offshoot of the U.S. study, the Hutchins Commission report, a late-1940s survey of the press brought about to study 
ways in which a commercial media could be made accountable to the public good. Nerone et.al. (1995) have pointed out that the Four Theories wasn't so much a set of theories as four expressions of one world view: Western liberal thought. Also, as Nerone and Merrill (2002) have argued, the social responsibility theory can as often be used to justify the suppression of free speech as the promotion of it, and one of the most interesting things about it is that it is often criticized as being good for journalism but bad for business, when, in fact, a strong case can be made for the reverse.

At the same time, over the period covered, there were such developments as objectivity becoming the ruling dogma of journalism and the concurrent explosion of punditry, the rise of ownership by chains and public companies, and a corporatization of newsroom management-outlined by many of the critics writing in the 1990s and 2000s. There is much in the current discourse to suggest that that these things are all still in place, and still holding the press in patterns that keep it from evolving to meet new challenges. A range of commentators-such as Carey, Dewey, Gramsci, Schudson, Williams and Norris - have argued that the press has alienated much of its audience with its limited notions of what is political, what is necessary for a democracy to function and who owns the concept of free speech. There is also the question, again posed by commentators such as Williams and Gramsci, of whether the press is a de facto publicity machine for the state, which frames the public conversation according to the interests of certain, select special interests. This is a point of view found in the earliest writings of Lippmann and echoed by modern 
critics such as Noam Chomsky, Edward S. Herman and Robert W. McChesney, and supported by Nerone et al.(1995).

Placed against the backdrop of the current discourse around the so-called dying old media and rising new media, there are some taken-for-granteds that need to be questioned, among them: the widespread belief that print is a dead or dying medium; the idea that amateur "citizen" journalists can replace the dwindling corps of professionals; the notion that the newspaper-and by extension magazines, film and television-will all be replaced by so-called new media; the drive to constrain journalism by a narrow definition of "professionalism," which would preclude meaningful participation by gifted amateurs, natural talents and autodidacts.

This is by no means a Luddite attack on the satanic mills of the digital age. Rather, the aim is to sift through the material on the crisis, and from it find a coherent narrative, which places the current discourse into a recent historical context.

IN JANUARY 2010, Tina Brown encapsulated much of the recent criticism of the press, when she wrote on her Internet news aggregator The Daily Beast that the claim that digital devices are killing newspapers and ending investigative journalism is "a load of Spam." U.S. dailies are dying, she wrote, because "they were so dull for so long a whole generation gave up on them."

One of the biggest fibs going is that American newspapers are now being forced to give up their commitment to investigative reporting. Most of them gave up long ago as their greedy managements squeezed every cent out of the bottom line and turned their newsrooms into eunuchs (Brown, 2010).

Brown's comments fit into a long history of discontent with what has lately 
come to be derisively called the "mainstream media." Compare her criticism to this quote, taken from the San Francisco underground newspaper Dock of the Bay in 1969:

The daily papers convey a very strong and very indirect message; there's a normal, everyday life which is OK and unexceptional. And then there's "news"; anything which stands out, anything that doesn't happen all the time and is, therefore, of interest. Life is good. That's the realm where things are taken care of. News is when something goes wrong. This is pure bullshit. ... The real news is what happens 24 hours a day all day long everywhere. This is the news we don't read about in the daily papers because the people who control those papers don't want us to know about it and do everything they can to distract our attention from it. Fortunately, they can't succeed. We don't need their papers to tell us the real news. All we have to do is open our eyes (Glessing, 1970: 108).

In their idealistic, stream-of-consciousness, ungrammatical exuberance, those words sound as if they could have been lifted from someone's blog. But we can reach back even further for damning criticism of an inadequate press, to 1920 and Walter Lippmann's Liberty and the News, which also sounds like something that could have been written yesterday, condemning the "gatekeepers" of information in the "MSM."

So long as there is interposed between the ordinary citizen and the facts a news organization determining by entirely private and unexamined standards, no matter how lofty, what he shall know, and hence what he shall believe, no one will be able to say that the substance of democratic government is secure (Lippmann, 1920: 7).

So, an exploration of the current "crisis" in journalism must be framed by a tradition of criticism that reaches back almost a century: from Lippmann and Dewey to Schudson, Carey and John Durham Peters, through exploratory commissions in the United States, Canada and Britain, and a score or so of late 20th-century media critics, and with side trips to visit the likes of Gramsci, Habermas and Williams. From Liberty and the News to Dock of the Bay, to The Daily Beast. 
Today's press also needs to be put into historical perspective for, as Robert McChesney and John Nichols (2010) point out, much of our current discourse on the state of newspapers is rooted in the belief that private ownership of the media always has been the dominant business model, and that its decline therefore must also signal a decline in journalism. Similarly, much of our thinking about the press is fixed to the doctrine of objectivity, "an ideology of distrust in the self" (Schudson, 1978: 71) that has only come into vogue in the news business over the past half-century or so. As we noted earlier, objectivity also is responsible for the separation of fact and opinion, which, as Alterman (1982) and Schudson (1978) have pointed out, gave birth to the punditocracy that seems to rule so much of the current media. Similarly, the Four Theories of the Press (Siebert et al., 1963) can be seen as a straitjacket for journalism and as a political-social shorthand that is far too simplistic to be of any use as a guideline for the craft (Nerone, 1995).

If we are to contemplate a future for journalism, it seems necessary to understand its past, particularly its recent past, through the postwar era of objectivity and social responsibility, through the chains, public companies, convergence, and the notion of news, information or "content," as a resource. And we need to establish that there is a history before that recent past. In acknowledging that journalism has evolved from partisan, state-supported press to popular yellow journalism, to objective media of record, to an amalgam of amateur and professional enterprises, we give ourselves licence to imagine a future that could involve similar evolution.

AS SEVERAL commentators have pointed out, one thing that is striking about the 
current climate of gloom is how the lines have been so blurred between business and craft, economics and aesthetics. As contradictory as this may sound, the recent financial crisis was much more a problem of the chains and conglomerates, than of their individual holdings. Many, if not most, specialty TV stations and newspapersparticularly ones under 100,000 circulation - would have done fine financially, if they hadn't had to service their parent companies' debts. Yet, the inference taken from the economic meltdown largely was that what is bad for owners of newspapers is bad for newspapers, and what is bad for newspapers is bad for journalism and journalists.

Also, as Bob Franklin argues in Journalism Studies, there is an "evident Manichaeism" in the prognoses being presented for newspapers (2008: 631). On one hand, we have the people who profess to have determined with scientific precision the date newspapers will cease to exist -as one did recently, with the prediction that the last daily would roll off the presses in 2022 (The Australian, 2010). Meanwhile, in 2008-09, U.S. dailies lost 10.6 percent of their circulation, and there are those who point out that reducing circulation by 10 percent is actually a good thing, if you raise your cover price by 11 percent, because you cut production costs while maintaining your income (Gross, 2009). And the 2009 year-end figures for the New York Times seemed to bear that out: daily circulation down 7.3 per cent; Sunday circulation down 2.7 percent; revenues up 6.7 percent (ibid.). So, depending on whom your read in 2008 and 2009 , you could draw the conclusion that the end is nigh, or that dailies experienced a small decrease in profitability in the face of the worst economic downturn since the Great Depression - and one for which the executives at General Motors or Chrysler would have been happy to sell their children. Sales and profit 
figures have since indicated that this downturn is no mere dip in the income charts for the newspapers, but a fundamental change in the economics of publishing and advertising. Yet, even now, the tendency persists to interpret bad news for chains and a certain class of daily newspaper as applying equally to all news media.

ERIC ALTERMAN (2008a) has argued that the stresses existing between the network society and the mainstream media are an extension of the so-called Lippmann-Dewey debate: the MSM is the Lippmannian gatekeeper or watchdog, speaking down to the great unwashed; the wilder, less organized and reader-driven Internet fulfils in the virtual world the concept of the conversational society expressed by Dewey and more recently Carey. That comparison is interesting in that it also reflects the Manichean outlook Franklin talked about: it implies that one must side with Lippmann or Dewey, because the former is an anti-democratic Platonist bent on removing the public from the Public Sphere, as Carey (1997c) put it, and the latter is an idealistic dreamer seeking a Great Community in Aristotelian ideals of a great Common Sense, while forgetting that Aristotle warned democracy could only exist within the reach of the human voice. Also, it involves the assumptions that a) print is a dead medium or at least in the final stages of terminal illness, and that $b$ ) news on the Internet is inherently more democratic and less institutional than news in print, and is destined always to remain thus.

Similarly, this black-and-white outlook demands that we choose technologies. We can embrace the Web and give ourselves over to social media, tweet out every banality that comes into our heads and develop the attention spans of fruit flies. Or we 
can become dinosaurs, who sit surrounded by piles of old newspapers, staring at the television and waiting to be carried out to the blue box. Yet, going by the history of how old media adapt to competition from new media, there seems to be considerable probability that digital media is here to stay and will continue to transform our lives, and print will remain the preferred method of delivery for certain types of information or narrative, but not necessarily on paper. As Shirkey (2009) has pointed out, the emergence of bloggers and citizen journalists is probably no more a threat to professional journalism than the fact that we all can drive is a threat to professional auto racing.

There is a distinct possibility everyone in this discourse is right, and no one is - and that is what makes it so interesting.

There always has been enormous middle ground between the contrasting points of view, as Williams (1983) demonstrates in his criticism of "old democrats" such as Dewey and "new skeptics," like Lippmann. He points out that there will always be "cheapjacks"- hucksters and opportunists - who will exploit communication for their own ends, and that we're all susceptible to manipulation by people shrewder and less scrupulous than we. Similarly, Schudson (2008) points out that there is more evident Manichaeism in the way Lippmann is exploited as the embodiment of the elitist gatekeeper and Dewey as the prophet of the conversational society. It was never so cut and dried, and it is as possible to use Dewey and Lippmann to argue one point of view, as it is to set them in opposition.

Meanwhile, more recent commentators, such as Samuel L. Popkin (1991), Underwood (1995), Miller (1999), Bagdikian (1990, 2004), Norris (1999, 2000), 
James A. Stimson (2004) and Joan Didion (2006a) have questioned whether we should be analyzing the press to find the reasons for falling reader interest, rather than blaming the audience, the technology or a "broken business model." As Williams (1983) has pointed out, we should never assume that the crowd is not a public simply because it fails to share the interests of those who govern it, or of those in the media who choose to champion the interests of the powers that be. People are highly political when their interests are involved, and their "inertia and apathy" (ibid.:316) are the only weapons they have to use against those who refuse to address those interests.

THOUGH THE recent recession started in 2007, it wasn't until mid-2008 that the panic of the press began in earnest. It was then that I began collecting daily news reports, magazine articles and commentary on the subject of the "death" of newspapers, or journalism. I followed the narrative, as it unfolded through the economic collapse and bounce-back, hoping that, at some point, some sort of equilibrium might be reached, where we might be able to draw a reasonable conclusion on at least the immediate future of the craft and the business. As of late2012, the so-called crisis had subsided, the flood of predictions, prescriptions and eulogies had slowed to a trickle, and the chains had returned to business as usual -or at least to their focus on broken business models, bottom lines and saviour technologies.

Meet the new order; same as the old order.

Some of that flood of commentary contained the same criticisms and 
complaints highlighted by Brown, and which hark back-at least in terms of the concern about readers turning away - to works such as Miller's Yesterday's News (1998), Underwood's When MBAs Rule The Newsroom (1995) and Bagdikian's The Media Monopoly (1992). This has been obscured by a fog of facts and figures that treat the current downturn in the fortunes of the business as being mostly, if not solely, the fault of a "business model" smashed by the "new media." This wave of gloom has been treated as something entirely separate from the previous 30 years of media history, in which criticism focused on other factors that were perceived to be affecting circulation and alienating readers: blandness created by chain ownership; timid management; unimaginative editorial leadership; too much focus on political gamesmanship over issues; trivia and pseudo-events presented as news; drab, awkward writing; interests too closely aligned with the rich and powerful. Some of those factors have figured prominently in several recent audience surveys conducted in Canada and the United States (The State of the News annual reports, Canadian Media Research Consortium 2004 and '08), as well as in the current criticism that has taken notice of historical precedents.

Meanwhile, a perceived ongoing crisis of management has become something of an obsession for those dedicated journalists who contribute to online forums. A particularly good example of the tone of the comments is this one, from someone who calls him or herself RMP, posted on the Toronto Sun Family website.

I have sat in board meetings where senior executives have been more interested in the quality of the food that was served than in the business being discussed. I have seen exceptional employees tucked into quiet corners and incompetent ass-kissers promoted. I have seen the exodus of talent and witnessed quality newspapers that turned into glorified flyer carriers. ... I am not sure how much longer I can remain 
in an industry that is being systematically cannibalized by delusional management. I can only hope that an industry "leader" finally comes along that is willing to listen to the voices crying out in the wilderness (2010).

Similarly, Alterman has written off most U.S. news executives as "completely off their respective rockers" (2008), and Underwood's When MBAs Rule the Newsroom (1995) is an entire book about management practices that undermine quality journalism. In fact, there has been a steady stream of similar criticism flowing through the pages of trade journals and various books on the industry, such as Bagdikian's New Media Monopoly (2004) and, in Canada, Miller's Yesterday's News (1998).

MOST OF the end-time predictions for the industry fail to take into consideration that virtually all of the injury to the newspaper business model —or, perhaps more accurately, "revenue model" (Picard, 2010: 18) - has been self-inflicted. Newspaper budgets were hobbled by the accumulation of debt resulting from the wave of acquisitions by large media companies over the past two decades and by shareholder demand for return on investment. Meanwhile, there were the decisions to a) give away the daily paper online, and b) not to move classifieds online before competitors, such as Craigslist and Kijiji, could take over the field. Huge debts (for example, Tribune's $\$ 13$ million leviathan, which dragged a mostly profitable collection of daily newspapers and TV stations into bankruptcy protection) have starved many media companies, creating a short-sighted, bottom line-focused management that has consistently sacrificed quality of content for cost of production. 
Also, there are some areas of research that seem obvious but have been underexplored. We know newspaper readership is growing in such countries as China, India, Brazil and Argentina (The Economist, 2008). Why? And how is it that community newspapers in North America are thriving, when dailies are in trouble'. Also, we are hearing the first rumblings of a movement to unplug, at least some of the time, from the Internet, and indications that digital applications for smart phones and tablets, some of which bear a strong resemblance to the printed page, are drawing people away from the Web. All of this could signal a normalization of novel technologies that have their limitations, as do all media.

What I have attempted to do is look at the craft, business and technology of journalism by examining the flood of commentary-mostly in the popular and industry press - over the past couple of years, organizing it and putting it into some kind of historical perspective. I also have tried to sift out the obvious hyperbole, selfinterest and repetition of much of that commentary, highlighting the apparent contradictions and reconciling them where possible, and constructing a balanced narrative of the period, without attempting to "win the case" for one medium or another.

\section{Chapter outline}

\section{1: Language \& power}

This chapter examines the notion of the public, mostly as it has been defined over the last century, looking at the various interpretations of the role, value and reliability of public opinion in the democratic process, and the part the press plays.

\footnotetext{
The first word that comes to mind in all these cases is "relevance."
} 
The focus is on one of the central questions of this debate: To what extent and in what ways can the news media be expected to advance citizen involvement in democracy? This involves examining the concept of the newspaper as an instrument of public policy, and as a business, and the concept of audience in relation to news media: the question of crowd or public, engaged populace or phantom public. I don't pretend to be an expert on philosophy or political thought, so my brief survey of such scholars as Burke, Milton, Habermas, Hobbes, Hume, Rousseau and Locke limits itself to how they deal with popular concepts of public opinion and the Public Sphere over the years.

2: Ink, steel, flesh \& money

This chapter is an admittedly rambling compendium of selected sources on the history of publishing, the media and journalism, ranging from Briggs's and Burke's Social History of the Media, and Paul Starr's The Creation of the Media, to the writings of Schudson (1978, 1995, 2003), Teel, Davies and McPherson (2006) Kesterton (1967), Fetherling 1990) and Sotiron (1997) and a variety of more focused material, such as histories of specific news companies.

The purpose of this chapter is to place the current state of journalism, technology and the news media into a continuum. For example, the abhorrence of Fox News in some quarters and MSNBC in some others might be a little less strident, if we considered that, in earlier times in North America, party-press affiliation was the norm, as U.S. commentators such as Starr and Schudson, Britons Briggs and Burke and such Canadians as Kesterton and Fetherling document.

I also briefly track narrative styles in the press over the years (to set up the 
three final chapters) and contrast the evolution of the Canadian, U.S. and British press, which, if nothing else, may at least further highlight the mythology of permanence that surrounds the corporate news media. I also put the technological developments into some kind of historical perspective by looking briefly at how technologies have transformed narrative and information from the printing press to the modern media conglomerate and the convergence mania of the late 1990s and the 2000 s.

Also striking is the way technology has created opportunities for journalists over the years, from local radio, which freed journalism from the expense of ink and paper, to television, which allowed a sort of passive participatory journalism and citizen involvement as the object of news, to offset printing and photo typesetting in the 1960 s, which opened up the field to smaller players and created the alternative press movement, to desktop publishing, which brought glossy production values to every copy desk and eliminated entire sectors of news workers, to the Internet, which allows anyone with a computer and a Web connection to be a publisher.

\section{3: Cries, curses, criticism \& complaints}

This chapter looks at selective media criticism over the past century or so, from Lippmann (1920) and Dewey (1954) to Bagdikian (1992, 2004), Schudson (1995-2008), Carey (1997) and other late-20th century/early 21 st-century media critics. One of the striking things about the legacy of criticism of the press, and much of the writing on public opinion and mass communication in this time are the recurring themes and the similarity of the criticism of the press in Lippmann's time to what was coming from the underground press in the 1960 s and '70s, to what we've 
been hearing and reading since the Second World War.

This chapter looks at the focus of press criticism over the past 30 years, at consolidation, convergence and control by publicly held companies. The Hutchins Commission, Four Theories of the Press, Canada's Davey and Kent Commissions, and the work of late-century media critics. This will lay the groundwork for the next chapters, which partly examine how the criticism continues into the current discourse. Intertwined with this is recurring pressure from some quarters to establish a set of professional standards, which has always seemed to be more of an attempt by the bureaucratically inclined to erect barriers to the raw talent, courage and imagination that tends to make interesting art-and which is exploding on the Internet.

\section{4: Dialectic of gloom: business}

Over the past few years and mainly since 2008 , there has been a flood of reportage, commentary and debate, in print and online, about the future of newspapers. Commentators such as Shirkey, McChesney, Alterman, Schudson and Rosen have weighed in with everything from dire predictions to prescriptions for renewal, to Internet evangelism, as have many journalists, business writers, bloggers, media critics and casual observers in the popular press and online. Some, notably former Slate media critic Jack Shafer, Columbia Journalism Review's Ryan Chittum, and the New York Times's David Carr, have provided ongoing, informed and thoughtful commentary, which I have found invaluable. Many have jumped in looking for the simplistic and the high-concept and then jumped out. Some have had the slightly hysterical don't-say-we-didn't-warn-you tone of the vested interest. (A $C B C$ News: Sunday item went so far as to announce "The End of News"). And, as 
always, there have been many with an anti-press agenda, whose predictions smack of wish-fulfilment fantasy.

This chapter looks at the debate over the future of the business, whether it belongs to online publications and citizen journalists, or professionals, or a hybrid of old and new. For the most part, this revolves around the "broken business model" mantra that the financial side of the industry has adopted as an all-purpose answer for any question. It also, for the most part, involves a near unquestioning faith in digital delivery as the saviour technology that will see the business into the future. This conversation ranges from those who argue that non-profit, or limited profit Web sites, such as Propublica and Global Post are the answer to preserving a free press that will safeguard democracy, to those who envision a world in which reporters carry cameras, microphones and smart phones and tweet, tape and write their stories for all media, to publishers who gleefully eye a future in which the readers vote on the news, write it themselves, and then buy back their own work-eliminating the need not just for ink, paper and delivery people, but for writers, photographers and editors, too (all of which I will look at more closely in the following chapter).

This chapter surveys a large selection of the commentary and reporting on the business over the past two years to map out the various developments and points of view. Much of this reads like the work of competing prophets. So, I have tried to strain out the hyperbole and proselytizing, and compare and contrast the various points of view and bits of information to sketch out a brief, chronological history of the past two years, in terms of technology and business, in the media industry. 


\section{5: Dialectic of gloom: technology}

This chapter looks at technological developments that affect the business and, therefore, have a trickle-down effect on craft, in terms of manpower and budgets and so on. It also looks at some of the ways technology is transforming the practice of journalism, opening up new audiences and new fields of endeavor.

The ongoing challenge of technology and new media has been how to make it pay. The Internet has proved to be an efficient demolisher of capitalism in terms of deriving from each according to his ability, but has been less effective in delivering to each according to his need. As a result, manpower has been affected by the developments of armies of bloggers and citizen journalists, as well as by sites, such as eHow and Studio 101, that pay writers minimum wage if at all, and Huffington Post, which recruits bloggers who contribute for publicity alone, and no pay. Similarly, freelancers have taken to the Internet as bloggers, often to promote their work elsewhere, sometimes-especially in the case of retired journalists - as unpaying vanity projects, sometimes as profit-making endeavours, and sometimes as a way to build a brand that can be sold to other media. The result is a glut of opinion and analysis, and a predictable devaluing of the writers' and reporters' product.

At the same time, news organizations are wrestling with the problem of getting paid for what they produce. As we saw in the previous chapter, media companies chose to give away the store in the 1900 s, and failed to leverage assets such as classifieds - that could have paid off online. Now, some companies (such as News Corp.) are experimenting with paywalls or are working on making new digital devices, such as smart phones and tablets, work as subscription delivery devices.

At the same time, the Internet is changing the way journalism is practised. A 
survey of such sites as The Daily Beast, Huffington Post, ProPublica and Global Post shows that there are people working on new ways of funding journalism, as well as new ways of telling stories, and displaying graphic elements.

\section{6: The dialectic of gloom: craft}

In tandem with the debate over delivery systems and business models, there has been a quieter conversation going on, which has its roots in media criticism a century old. This conversation revolves around the state of the craft and how it will adapt to new media, with the expectations of a distracted time-pressured audience, and with the stresses being placed on journalism by economic factors. In this chapter, I look at the proposition that journalism, as Adam wrote, "can be and often is an art form" (2006: 344 ) or at least a craft, and that the news media are a form of popular culture. As well, I review a range of Web sites by, for and about the craft, such as Reflections of a Newsosaur, Toronto Sun Family, PressThink and Paper Cuts.

I also look at the stresses being placed on newsworkers by the new "fluid" (Deuze, 2007) work environment, which has thrown masses of people out of work and, at the same time, opened up possibilities for new ways of practising the craft of journalism and, at the same time, for individual journalists to capitalize on their work. On one hand, as we saw in Chapter 5, technology such as Twitter and Facebook have created new tools for reaching audiences and sources, and participatory journalism has extended the reach of journalists and enriched the character of journalism. On the other, journalists are being driven to unethical and even corrupt practices in the effort to make a living, from gotcha journalists who manipulate facts to suit a political agenda to bloggers who accept gifts and favors. 
The idea is to sketch out the landscape of the media and the press from a different perspective from that of Chapter 4: from the viewpoint of journalists and theorists concentrating on the question of how to propel journalism into the future, regardless of whether the media business has one.

\section{Conclusion: Neoprotopostmodern times}

Having mapped the landscape, we can now pick our way through the milestones, contradictions, over-simplifications, generalizations and demonstrable fallacies. The press is useful as a running, day-to-day commentary on the world, but its main weaknesses are that it usually fails to provide context and rarely revisits stories to update them. What emerges is a patchwork of random pieces of information that need to be compared, contrasted, reconciled to one another and stitched together into a whole story.

This thesis doesn't pretend to deliver a prescription for the revitalization of the daily newspaper, or for its perpetuation on the Internet, and that's not what is intended. Rather, the argument appears to have unfolded in favor of the daily newspaper and the Internet, in that there are things the latter can do that few of us would want to give up, and there also things the printed page can do that we would be best not to let get away. A pre-Web world would be a drab and frustrating place for anyone who has come to enjoy the pleasures of instant access to masses of information and entertainment at the touch of a fingertip, and for anyone who relishes a future in which the audience is allowed to contribute to the conversation. However, there is an aesthetic and educational use for print material - on paper or tablet-that the Internet cannot satisfy. The daily paper, and magazine and book, may survive 
simply because some forms of graphic, photographic and literary presentation are more pleasing-or more fun-in print than on a computer or tablet, because people read differently in hand than they do online, and because neither medium can satisfy every informational need or deliver every kind of reading pleasure. For comparisons, one need look no further than video games, film and television. Anyone who ever predicted that video games would replace film or TV forgot-or never experiencedthe pleasure of a story told well, of giving oneself up to the experience, of climbing aboard and enjoying the scenery. Similarly, anyone who says television is dead hasn't been paying attention to the flood of important drama being turned out by the cable networks: The Sopranos, Six Feet Under, Deadwood, Dexter, Slings and Arrows, Breaking Bad, Mad Men, The Killing, Boardwalk Empire, The Borgias. It is not difficult to make a strong argument that the most important drama is on television. The audience may be fragmented and the technology in flux, but, if anything, the medium is more vital than ever. People continue to read novels, though film is more than a century old. Radio and movies continued to flourish, in altered form, after the advent of TV. Further proof of a continuum may be taken from the facts that in 2010 , Atlantic Monthly posted the most profitable month in its 153-year history (Folio, 2010).

Yet, the criticisms of the industry remain, and they remain valid, especially since media management appears to have settled back into a business-as-usual mode. This, unfortunately, doesn't bode well for the industry's will to address these criticisms - or to develop print media that can find useful niches in a radically altered media landscape. 


\section{Language, people \& power}

THE DEBATE over whether a citizenry constitutes a mob or a public is at least as old as democracy, and probably even older is the use of language to mould citizens into a public or to manipulate them as a mob. Since the invention of the printing press, communication technologies have been "central to the practices and organization of politics" (Barney, 2004: 108). And, for as long as there has been politics, language has been used as a tool, or a weapon, to appeal to the intellect or the emotions, to try to guide people in directions that move society forward, to serve special interests, or to trigger the destructive instincts of the crowd. The problem always has been how to ensure that the "conversation of the culture," as James Carey called it, is reliable, impartial and trustworthy, and serves society rather than subverting it. This is particularly acute in democracy, where public opinion raises up and tears down the leadership that steers the state. In a feudal society or other form of tyranny, questions of public opinion can be easily settled with a few heads on pikes; in a democracy, citizens need to be wooed and persuaded with language.

We live in an age in which language includes images and sounds, and an age of mass persuasion in which the conversation of the masses is breaking down into a diffuse and somewhat discordant collection of special interests engaged in semipublic conversations, and in which more and more of the conversation seems to consist of the persuasive monologic discourse that Jurgen Habermas equated with 
violence. This has presented us with a new question to debate: Are we freeing this conversation of the culture from the gatekeepers of mediated information, or dismantling the institutions whose job it is to monitor the reliability, trustworthiness and impartiality of the information that we need to govern ourselves justly and well?

As John Durham Peters points out, there always has been stress between those who trust public opinion and those who fear it. Plato believed in the superiority of epistêmê, the sure, verifiable, scientific knowledge possessed by the few, over doxa, the popular, unconsidered opinion of the masses. Aristotle preferred to put his faith in the public opinion that grows out of common experience, what the pragmatist William James was to call the Common Sense: "the habits of thought handed down through myriad generations and preserved in language" (Peters, 1989: 206).

Against the Sophists, who claimed that doxa was all that was available to human cognition, Plato made a fundamental contrast between the transient and the eternal: doxa was popular belief, unshaped by the rigours of philosophy, and was fickle and fleeting; epistêmê was sure knowledge of the unchanging "Ideas" underlying the visible world. Doxa was the stuff of the untutored many; epistêmê of the few. Plato believed that politics was a technê, or a skill that should be conducted according to scientific principles. Hence the task of ruling should be delegated to philosopher-kings, or experts (who see the universe according to epistêmê) ... (1995: 4).

Although this chapter does not attempt to draw a map from Classical Greece to the 21 st century, it will touch on several key points in the debate over whether the public is a phantom or a body politic, and look at the theories of public discourse and opinion that have grown up around it, particularly as manifest in the so-called "Lippmann-Dewey debate." On one hand, there is the notion that free speech empowers people who are least able to express themselves coherently: the easily led 
and the uninformed, whose participation in their governing would reduce society to paralysis, anarchy, or tyranny. Then, we have the response, that communication converts political inertia into dynamism, creating an informed public and transforming society into a community, with built-in safeguards against deception and manipulation.

AS MICHAEL Schudson (2008) points out, the Lippmann-Dewey discourse is something that has been treated as having its origins in the $1920 \mathrm{~s}$ - when journalist and political theorist Walter Lippmann and philosopher-psychologist-educator John Dewey were writing the works around which the "debate" is constructed. However, it really sprang up over the past quarter-century, as a construct by liberal theorists arguing over the role of media in society. So its establishment as a central dialogue in media studies runs parallel to a large body of criticism during the same period, which focuses on the growing concern over the corporatization and concentration of ownership in the news media.

Thus, it provides a convenient and logical starting point for any journey through the media landscape of the late 20 th and early 21 st centuries.

In the 17th century, Thomas Hobbes took up Plato's position and foreshadowed Lippmann's, when he warned against the "disturbing consequences of unrestrained speech" (Whelan, 1981: 59), and argued that the ruling elite must take it upon themselves to establish strict guidelines for the use of words, even in the case of "a term in scientific dispute ... that may breed controversy detrimental to peace" (ibid.: 61). Like Plato, Hobbes argued for a scientific approach to language, but 
regulated by the "sovereign" (any form of authority), and cleansed of its "abuses"metaphor, equivocation, eloquence and absurdity —-through which, people "devise errors and pass them on" (Whelan, 1981). At the same time, Hobbes warned of the dangers of allowing public opinion to influence policy, and that eloquent language can be used to guide the "assembly of many" in directions that may be against the public interest: "[I]n an assembly of many there cannot choose but be some interests are contrary to that of the public; and these their interests make passionate, and passion eloquent, and eloquence draws others into the same advice" (2001: 578-579). For Hobbes, language used in serious pursuits needs to be serious, and only through unadorned, cold-blooded communication can we avoid confusion, enflamed passions and discord. Thus, speech must be governed by the higher intelligence and more refined sensibilities of the ruling elite.

A century later, Edmund Burke defined the language of the French Revolution as a roar of anarchy that turned communication into "a Black Mass ... where the spilling of ink on pamphlets and proclamations causes real blood to be spilled and shed" (Blakemore, 1984: 291-292). Burke looked to France and saw Babel, a new language defining a new anarchistic European man, with which it was all but impossible to communicate. His fear and longing for stability is expressed in his insight that "history, tradition and reality are essentially linguistic and that the recovery of their presence resides in the recovery of their meaning through the inherited documents of the 'written past' recreated in present and future documents" (Blakemore, 1984: 290). 
Hobbes and Burke - both living in perilous times for ruling elites - saw language as so powerful and potentially dangerous that it needed to be controlled by the clear head of the "sovereign" and kept from the corrupting influence of the rabble'.

Opinion of the public and free speech are not always so bleak. In the Areopagitica, for example, Milton argued that reason would always emerge in a free and open encounter, and reveal truth:

And though all the winds of doctrine were let loose to play upon the earth, so Truth be in the field, we do injuriously, by licensing and prohibiting, to misdoubt her strength. Let her and Falsehood grapple; who ever knew Truth put to the worse, in a free and open encounter? (1644: 18)

MILTON BELIEVED truth was something that grew in the individual conscience, nurtured by the spirit, and that "the two greatest evils in human life [are] tyranny and superstition" (Guss, 1991: 1160). In the Areopagitica, "truth is a meaning within life, not an idea apart from it. It emerges from difference and conflict" (ibid.: 1158).

That can be taken to mean that truth is natural, bred in the bone, and reveals itself through a process of natural selection, or evolution. This places it within the confines of Natural Law, upon which the concept of Social Contract is based. Sir Ernest Barker defines the 11 decades immediately following Milton, from the publication of Hobbes's Leviathan (1651) to Jean-Jacques Rousseau's On the Social Contract (1762), as "the great age of the doctrine of the Social Contract ... the age in which the general background of Natural Law is firmly constructed and

\footnotetext{
'In postwar Britain, Raymond Williams described Burke's misgivings as a fear that the "swinish multitude" might "trample learning" (1983: 327).
} 
systematically illuminated (1948: xi)..." The central belief in all this is that human rights were written by God into the rules of nature and could be observed, understood, explained and defended through those rules, that a higher logic governed all things.

Donald Guss (1991) argues that by making personal conviction the focus of the struggle between truth and falsehood, the Areopagitica foreshadows Habermas's Ideal Speech Situation and Public Sphere, in that it "makes private conviction central to public discourse. ... [and] locates reason in what Platonists sought to overcome: particularity and struggle ..." (ibid.). It creates the so-called marketplace of ideas, in which the true and strong concepts win over the public, while the faulty and weak ones whither away. However, it is worth noting that even Milton placed limits on free speech, and for the same reasons Hobbes and Burke did; he would deny it to Catholics, a perceived threat to the protestant status quo in England in Milton's time (ibid.).

So, free speech is a moral imperative that arises from Natural Law and, thus, reason, which is a facsimile of the intelligence of God. This gives the weight of divine will to the contentions that government is founded "on opinion alone" (Hume, cited in Noelle Neumann, 1984: 133) and that laws are the "authentic acts of the general will" (Rousseau, ibid.). This neatly counters the concept of the divine right of the sovereign. At the same time, however, opinion is volatile and must be handled with care, and, in dangerous circumstances, kept out of the hands and mouths of those who would abuse it, which, as Hobbes argued, puts the balance of power right back into the hands of the ruling elite. 
In the 18th century, Habermas writes, "the debate between Platonist and Aristotelian points of view was being carried on by G.W.F. Hegel," who denounced the "anarchic and antagonistic civil society," and Immanuel Kant, who praised the elevating nature of public discourse (Habermas, 1991: 122). Communication and criticism were central to "Kantian notions of universality, cosmopolitanism, and science ..." (Calhoun, 1992: 18). And Habermas quotes from Kant's Perpetual Peace: "[T]rue politics can never take a step without rendering homage to morality" (ibid., 103). He argues that, in the 18th century, much of the Aristotelian tradition was "reduced ... to moral philosophy... whereby the 'moral' (in any event thought as one with 'nature' and 'reason') also encompassed the emerging sphere of the 'social'..." (1991: 102-103). Similarly, Habermas echoes John Locke's "distinction between persuasion and coercion ... aimed to allow peaceable zones of humane intercourse free of terror or compulsion" (Peters, 2005: 111). In other words, public opinion "can be formed only if a public that engages in rational discussion exists" (Habermas, 1989: 232).

Writing roughly two centuries later and also in a time of social upheavalpost-Industrial Revolution - Marx took the exact opposite approach to what is essentially the same argument as Hobbes. Like Hobbes, Marx argued for unadorned, plain language in political discourse, though his aim was to use language to carry economic and political theory to the streets and put it into the hands of the people. He urged the creation of a common language, which could inspire and empower the masses to rise up, seize control from the bourgeoisie and reorganize society for their benefit. "For Marx, genuine emancipation was possible only if such theory itself 
becomes a practical force ... but to gain this insight, language had to be demystified and translated, so that the 'masses' could understand it" (Cook, 1982: 538). Marx regarded language as "not a work, but an activity" (ibid.: 532). For him, words were tools that had been appropriated by the bourgeoisie and used for their benefit. Yet, unlike Hobbes, Marx saw language as something that could free the masses, were they only to take control of it and bend its meaning to their purposes. "Marx never faltered in his optimism that, once the esoteric quality of language was unmasked, the 'masses' could theorize and learn for themselves, understand their situation, and act on this understanding" (ibid.: 554). Like Hobbes and Burke, Marx wanted to defuse language's destructive power, but he wanted to do so by setting it free, rather than constraining it. Like Dewey later, he had a powerful faith in an educated public's ability to organize and govern itself wisely.

It was Habermas who defined the term "Public Sphere," as "a domain of our social life in which such a thing as public opinion can be formed" and "private persons come together to form a public ... acting neither as business or [sic] professional people ... nor as legal consociates subject to the legal regulations of the state bureaucracy and obligated to obedience. ... without being subject to coercion" (1989: 231). For Habermas, an informed public made up of private individuals, acting independently, without pressure and having the strength of their moral convictions, will hash out the truth in any fair and balanced encounter. Milton sees truth growing out of free speech; Habermas describes it as being manufactured by honesty, openness and tolerance. As Guss points out: "Milton says in a free and open encounter, truth will prevail, Habermas that what does prevail in such an encounter is 
true" (1991: 1164). For Habermas, there "is no breaking forth of light, no divine Word; there is only human discourse" (ibid.: 1160).

AT THE beginning of the 20th century, the conflict between epistêmê and doxa was moved to the centre of the new fields of communication and media studies by "the Platonist Walter Lippmann and the Aristotelian John Dewey" (Peters, 1995: 21). Simonson describes the positions of Lippmann and Dewey as an "intramural debate" (2001: 12) between thinkers who were the intellectual children of pragmatists such as William James and, like Habermas later, direct descendants of the Enlightenment. Again, the difference of opinion was over whether reason and truth would grow out of unfettered and inclusive debate or if the "trampling and the roar of a bewildered herd" (Lippmann, 1993: 145) would drown out the voices of reason and deliver the public into the hands of demagogues.

Dewey and his colleagues at the University of Chicago-George Herbert Mead, Robert Park and Charles Cooley - were fixed on the idea of communication as existence, as a way of being that forges mobs into publics (Park, 1972) and transforms society into a community (Dewey, 1954). Dewey's focus was the search for the Great Community, which had to be forged from the cold machinery of the Great Society. That resonates in Habermas's Public Sphere, Raymond Williams's common culture, and in James Carey's belief in the "conversational public," which he described as "a society of argument, disputation, or debate" (1997b: 217-218). It also informs Jay Rosen's call for a public journalism that sees "its own health is dependent 
on the health of dozens of other agencies which pull people out of their private worlds" (1999: 20).

Lippmann was something of a thwarted idealist, forever looking for the solution to a problem that is probably unsolvable: how to create mechanisms that will ensure democracy's survival in the face of such destructive forces as the tyranny of the majority, the manipulation of special interests and the lack of involvement of much of the public. In his lifetime, Lippmann had been a muckraking reporter, a founding editor of the New Republic, a propagandist, an advisor to presidents, an editorial writer, an influential syndicated columnist, and an author. He had studied with such thinkers as William James, George Santayana and Graham Wallas, and had apprenticed with the investigative journalist Lincoln Steffens. He had served on Woodrow Wilson's propaganda organization, the Creel Committee, which was charged with the job of selling the American public on joining the First World War. For virtually all of his adult life, he exercised political influence at the highest level. As one of his biographers put it: "The first American president to praise Lippmann and then break with him was Theodore Roosevelt; the last was Lyndon Johnson" (Adams, 1977: 9).

Lippmann had seen Europe destroyed by two World Wars and civilization threatened by nuclear annihilation. Much of the worst of it had been triggered by democracies in Germany and Italy, which, as they say, had committed suicide by election. Like Hobbes and Burke, Lippmann was a product of immense political upheaval and, perhaps, that is why, like them, he so abhorred disorder. And he had come to believe that the "rule of majority is the rule of force" (1963a). 
After periods as a socialist and a progressive, Lippmann settled into a theory of limited democracy, controlled behind the scenes by latter-day philosopher kings, a priest-class of technocrats, whose job it would be tend the machinery of the Great Society for the ruling elite (1997). People, he argued, could be expected to be only so well informed that they could be summoned to the polls periodically to choose their leaders.

The private citizen today has come to feel rather like a deaf spectator in the back row, who ought to keep his mind on the mystery off there, but cannot quite manage to keep awake. He knows he is somehow affected by what is going on. Rules and regulations continually, taxes annually and wars occasionally remind him that he is being swept along by great drifts of circumstance. Yet these public affairs are in no way his affairs. They are, for the most part, invisible (1993: 3).

As for the press, it could not be trusted to provide any kind of coherent picture of the world. The best that could be asked of it was that it play watchdog for the public good, and provide enough policy information for voters to make semiinformed choices every four years (1997). "The press," Lippmann writes, "is like the beam of a searchlight that moves restlessly about, bringing one episode and then another out of darkness and into vision. Men cannot do the work of the world by this light alone. They cannot govern society by episodes, incidents and eruptions" (1993: 229).

Though Carey admits that Dewey's ideas of the public are "unusually abstract and regressive," he argues that they comprise a "well-intentioned" attempt to "counter elitist notions of democracy put forth by Walter Lippmann and a subsequent army of social scientists who reduced communication to the transmission of information from 
those who monopolized knowledge to those who needed to be controlled in its name" (1997c: 72).

Carey writes that Lippmann, liberal theory and the Chicago School form a bridge "between the theory of public and freedom typical of the 19th century and the theory of media effects typical of the 20th" (1997a: 24). For example, Lippmann and the members of the Chicago School were united in their rejection of the 19th and early-20th century notions of social Darwinism. The biographer Ronald Steel explains Lippmann's support for William Jennings Bryant's prosecution of the famous Scopes "Monkey" trial of 1925 as a manifestation of Lippmann's revulsion toward the way evolutionary theory was being used to justify racism, bigotry and elitism at the time (1980: 216). The same way, one can read echoes of Natural Law into the thinking of the members of the Chicago School-such as in Mead's argument that "consciousness is social and the objects of our consciousness (including the self) are socially constructed" (Feffer, 1990: 241). For Mead, communication had its origins in the need for social animals to devise means by which they could cooperate and form themselves into a society. "People could not be human in any sense of the term unless $^{2}$ they were social" (ibid.: 239). It is Park who sounds the most like Lippmann, when he argues that, in its natural state, the mass is a crowd, "formed from the lowest, most brutal characteristics of its individuals" and given to acts of "wild cruelty" (1972: 9). Public opinion is "generally nothing more than a naive collection of impulses that can be manipulated by catchwords," and journalism manipulates those impulses to create and control the "collective attention" (ibid.: 57).

\footnotetext{
${ }^{2}$ Author's italics
} 
All of these men saw the public as bewildered by the scale, speed and violence of the new industrial society, and unable to take part in, or even cope with, the social and political changes of the 20th century. And they were united in their ambivalence about whether the press helped create a public, or manipulated a crowd. Where they differed was in the solution. The way Lippmann's biographer Ronald Steel puts it, Lippmann saw the public as "a Great Beast to be tamed," and Dewey a "force that could be educated" (1980: 218$)$.

However, the distance between Dewey and Lippmann was never so great as is often depicted, and there was little in the way of direct exchange between them. Rather, the so-called Lippmann-Dewey debate is something that mainly has been constructed around five pieces of writing: Lippmann's, Public Opinion and The Phantom Public, (two out of more than a dozen books, spanning some four decades), Dewey's mostly positive reviews of those books, and a series of lectures that were collected into The Public and Its Problems, which does answer Lippmann's pessimistic outlook. "What turned the Lippmann-Dewey discourse into a 'debate' were liberal intellectuals in the 1980s and 1990s writing at another moment of democratic disillusion as they sought to take stock and seek hope" (Schudson, 2008: 1032).

Through his life, Lippmann was not so much looking for ways to remove the public from politics, as Carey accuses, but rather to find a way to reconcile the two and to devise systems that might protect the public from the consequences of its decisions. As James Reston wrote in Lippmann's obituary in the New York Times, "The Central question of his life was whether what he defined as liberal democracy- 
an open society governed by law-could survive in a violent world" (1974). Lippmann's concern was that "the problems that vex democracy seem to be unmanageable by democratic methods" (1997: 179-180), and that pandering to the public opinion posed a threat to democracy while pretending to uphold it. "[L]eaders often pretend they have merely uncovered a program that existed in the minds of their public," he writes. This is a lie, because ideas don't emerge from the mass. "[T]hought is the function of an organism, and a mass is not an organism." The mass is "constantly exposed to suggestion" from special interests, who are out to move public opinion in the direction they wish it to go. "Thus the ostensible leader often finds the real leader is a powerful newspaper proprietor" (1997: 155).

Though Lippmann and Dewey agreed on the problem, they differed in the solution. Or, more precisely, Dewey thought he had a solution and Lippmann spent his life looking for one - growing more and more disillusioned as he lost faith in great leaders, technocrats and the media, yet always clinging to rule of law.

In The Public and Its Problems, Dewey argues against democracy being confined to the ruling elite of politicians and business-people, and for the importance of public deliberation in decision-making (1927). Though his review of Public Opinion is for the most part positive, he implies that Lippmann had given up on participatory politics because of a "lack of political imagination and a lack of faith in the powers of progressive education to forge a democratic public" (Schugurensky \& Myers, 2001). Dewey describes Public Opinion as "an experience in illumination" that is so compellingly written that "one finishes the book almost without realizing that it is perhaps the most effective indictment of democracy as currently conceived 
ever penned" (Dewey, 1985: 337). However, as Lippmann's view of democracy became more morose, Dewey became more critical. He described The Phantom Public as "an exaggerated and undisciplined notion of the public and its power" (Steel, 1980: 214).

Dewey didn't disagree with Lippmann's assessment of the public's difficulty in keeping up with events in the Great Society. In fact, he had high praise for "Mr. Lippmann's relentless and realistic analysis of the limitations of the pictures in our head about the environment and his account of the methods by which the privileged few supply a supplement and substitute so skillfully that the mass still thinks its opinions are valid and spontaneous ..." (1985: 339-340). In this world of half-truths and withheld information, he writes, "the Public seems to be lost; it is certainly bewildered" (1954: 116-117). The problem was that the Great Society had "invaded and partially disintegrated the small communities of former times without generating a Great Community" (ibid.: 127). To Dewey, the public wasn't disaffected. It was waiting to be reassembled. Voter apathy, he argued, had been created by the dislocation of the people by this soulless Great Society. Educate people and you eliminate the apathy; eliminate the apathy and you humanize the society. "The prime condition of a democratically organized public is a kind of knowledge and insight which does not yet exist" (ibid.: 166). Dewey argues that only when the old local community grows into the Great Community will the public be brought into existence. To do this, he exhorts communicators to become artists and educators. To create "an organized and articulate Public" the "art of communication must take possession of the physical machinery of transmission and circulation and breathe life 
into it" (ibid.: 184). As Kaufman-Osborne points out, Dewey's thinking borders on the mystical.

In Dewey's political writings, then, one encounters the paradox of a philosophy which praises science for its creations of the conditions necessary to democratic community but which destroys the experiential foundation of community in the process of fulfilling its own logic (1984: 1159).

Dewey argued that education was the key to transforming the populace into a public. Educate the people and stimulate their imagination, and they will enter into the discourse of society and create a Great Community (1954). What was needed to accomplish this was for the forces of communication to come together to educate the masses, something he admitted would be no easy task. "The union of social science, access to facts, and the art of literary presentation is not an easy thing to achieve. But its attainment seems to me the only genuine solution of the problem of an intelligent direction of social life" (1985: 343).

Like Mead, Dewey saw democracy as more than a political system. It was a culture, an "idea of community life itself” (ibid.: 148) and a natural human condition. Dewey defined the yearning for community as the central problem of a Darwinistcapitalist system ${ }^{3}$ and saw the challenge of political communication as being to forge a larger community out of a soulless technocratic society. To create a community, Dewey believed, "requires communication of that which individuals are able to hold in common" (Kaufman-Osborne, 1984: 1151).

\footnotetext{
${ }^{3}$ Something about which the members of the Chicago School all expressed great misgivings, possibly because of their concern with underclasses. Mead and Dewey were involved in labour mediation. One of Park's main preoccupations was race relations. And the University of Chicago sat on the edge of the stockyards and rail yards, providing a handy laboratory in which to study the evils of laissez faire capitalism in the early 20 th century.
} 
Lippmann agreed that people are disengaged from public life, or at least confused by it, and that the media over-simplify, sensationalize and confuse issues, rather than explain them. Unlike Dewey, he had little or no faith in the media or politics to address the problem. In Public Opinion and The Phantom Public, he delivered what Christopher Lasch called "the most sobering assessment of the public's incapacity for critical judgment and self-government" (1991: 363). In the first book, written in 1922, Lippmann described public opinion as constructed from stereotypes (taken from the printers' term for reusable type, set in metal plates) which people use as substitutes for deeper understanding - or as shortcuts to get to conclusions without passing through critical thought. He also expanded an argument, which he developed in Drift and Mastery, that a technical class could educate the masses and advise the elites. The title refers to the inertia of the public (drift) and the purposeful planning of government (mastery).

There is nothing accidental, then, in the fact that democracy in politics is the twin brother of scientific thinking. They had to come together. As absolutism falls, science rises. It $i s^{4}$ self-government. The scientific spirit is the discipline of democracy, the escape from drift, the outlook of a free man. Its direction is to distinguish fact from fancy; its "enthusiasm is for the possible"; its promise is the shaping of fact to a chastened and honest dream (Lippmann, 1978: 151).

When he wrote The Phantom Public, five years after Public Opinion, Lippmann's outlook had become so gloomy that he believed the role of the citizenry should be limited to electing governments to rule it.

There's no mistaking the similarity between Lippmann's comments about the public being made up of "deaf spectators" and these by Dewey: "If a public exists, it

\footnotetext{
${ }^{4}$ Author's italics.
} 
is surely as uncertain about its own whereabouts as philosophers since Hume have been about the residence and make-up of the self' (1954: 116-117). However, Dewey's definition of communication is bound up in James's Common Sense. "The essential need," he wrote, "is the improvement of the methods and conditions of debate, discussion and persuasion" (ibid:: 208). Dewey believed that the Great Society could be forged into a Great Community through communication.

Dewey did not dispute Lippmann's contention regarding journalism's flaws or the public's vulnerability to manipulation. But Dewey thought Lippmann's cure was worse than the disease. While Lippmann viewed public opinion as little more than the sum of the views of each individual, much like a poll, Dewey saw it more as a focus group. The foundation of democracy to Dewey was less information than conversation (Alterman, 2008).

PETERS PUTS Habermas's Structural Transformation of the Public Sphere and Raymond Williams's Culture and Society in this continuum. He also places them among the four "texts that reflect the dawn of common dreams" (along with Aldous Huxley's Brave New World Revisited and Hannah Arendt's The Human Condition). What they have in common is that they are works that "point to a vibrant, democratically engaged politics," and "deal with the threat of mass society, of lonely crowds, and seek ways to rebuild a more vital democracy" (2003: 221).

The Bourgeois Public Sphere, as Habermas defines it, was formed in the 18th century, at a time when feudalism was being replaced by capitalism, and the idea of public power was evolving in tandem with the concept of private property (1991: 231-232). It came into being with the nation state, and was born as "the sphere of bourgeois society which would confront the state as a genuine domain of private 
autonomy ... the sphere of private persons assembled to form a public" (ibid.). The salient feature of the Public Sphere is that it is inclusive. All who live in it are free to take part in it. "Under the pressure of this principle, communication becomes the quintessential Public Good, open to all and considered to be a cornerstone of modernity and democracy" (Winseck \& Cuthbert, 1997: 8).

With his definition of the Ideal Speech Situation, Habermas lays down conditions for pure democratic communication: an open exchange of ideas by people unafraid of persecution, reprisal or censorship and unfettered by bias or preconception, and in which statements are intelligible, verifiable and truthful, and everyone has an equal chance to speak. "Together these conditions specify a norm of communication that can be named that of egalitarian reciprocity" (Benhabib, 1992: 89). With that formula, Habermas-like Milton and Locke before him-tries to define the conditions for pure democratic communication. However, as we have seen, unlike Milton, Habermas argues that truth is external, and that it emerges from discourse. Persuasive monologic speech, which seeks to manipulate or conceal truth, is associated with "violence ... and 'strategic action' ... When discourse seeks control over others, it alienates and colonizes all who use it; when it seeks understanding, it brings freedom" (Guss, 1991: 1160). To Habermas, the question is moral, ethical and political. Truth and rightness are not abstract concepts, but "products and causes of solidarity" defined by the "agreement they evoke within an ideal speech situation" (ibid:: 1161).

Like Dewey and Mead, Habermas believes that the public is called into being by communication-but through a specific type of communication. To Habermas, the 
“bourgeois Public Sphere institutionalized, not just a set of interests and an opposition between state and society, but a practice of rational-critical discourse on political matters" (Calhoun, 1992: 9). Also, like a culture, the Public Sphere is something we inhabit, and is not a conscious construct but something that grew in response to political evolution. It is a state of existence with rules that must be followed if we desire order and civility, and it is not very different from Dewey's Great Community in the benefits it bestows and the demands it makes on citizens. Within it, public opinion comes into existence from the free expression of privately held views, as a consensus arrived at by private individuals "who join in rational-critical debate on an issue" (ibid.: 17). Ideally, this is shaped into policy by democratically elected governments, who are responsive to their constituents' needs and desires. Yet, Habermas is careful not to confuse public opinion with public power. He is not arguing for government by plebiscite, but for a structured, orderly and open system that heeds the voice of the people between, as well as at, election times. "Discourses do not govern. They generate a communicative power that cannot take the place of administration, but can only influence it" (1992: 452).

THIS BRINGS us back to Peters's struggle between doxa and epistêmê, which, as Schudson (2008) has pointed out, is also the difference between representational and direct democracy. In the 1990s, Schudson and Carey picked up that struggle, with Schudson in the role of realist and Carey playing the communitarian-and Peters taking on the role of "Jamesian godfather" championing a "pragmatism open to the uncanny and the practical" (Simonson, 2001: 16). Like Lippmann before him, 
Schudson (1995) argues that it is unrealistic to expect society to be composed of perfect citizens paying careful attention to politics and policy, and equipped with the wherewithal to understand even the most complex issues. As for the news media's ability to inform the citizenry, as we have seen, Lippmann believed that was like expecting a searchlight to illuminate an entire building. All it can do is show fragments, which the audience is never able to piece into a coherent whole. Schudson sees the problem slightly differently but the result the same. He draws our attention to the difference between an informed citizen and an informational citizen, and asks whether we are "disabled by media saturation" and "distracted or deadened, or at least thrown off stride by the avalanche of information" (1995: 170). The act of living in this complex, demanding, maddening society, he argues, takes up most of our time and concentration, and what little is left over is usually directed towards things that interest, entertain and amuse us - and it probably always has been thus.

The public has ever been fictional. It is a democratic fiction par excellence, carried by the imaginations of people in authority who want to get things done or by people without authority who believe a better world can yet be made and sustained in good times and bad by republican institutions-elections, a free press, parties, the rule of law, and the arts of association. It is the fiction that brings self-government to life (1995: 32).

So, the public is a useful fiction or mythology, and there's no point in wishing it were otherwise. Schudson's arguments are supported by political pollsters such as Philip E. Converse, who concluded, after a study in 1964, that only 10 percent of the U.S. population had any coherent set of political beliefs, and the majority who answered questions did so simply because the interviewer expected a response. 
It is hard to overstate the evidence of public ignorance, hard to express the analysts' initial despair at finding out what isn't known by people on the street. ... The gap between what democracy seems to demand of voters and what voters supply is just immense (Stimson, 2004: 14).

To Carey, the public is neither fictional nor dispensable, though he laments that it "has been pretty much evacuated in our time" (1997b: 218). He sees public opinion as manipulated and moulded to be leadership-friendly by polling, and the public replaced as the principal political force by interest groups, which are by their very nature private and hidden from public view (ibid.). In Carey's view, restoring democracy is a matter of restarting the public conversation, which "not only forms opinion, it forms memory" (ibid.: 220). Lippmann, Carey argues, "depoliticized the Public Sphere" (1997a: 23) and, "in effect, took the public out of politics and politics out of public life" (1997c: 245).

The trick Lippmann pulled off was this: he legitimized a democratic politics of publicity and experts while confirming the psychological incompetence of people to participate in it. He tried to show how you could have "democracy without citizens" ... while preserving a valuable role for the mass media (1997a: 24).

Lippmann's so-called anti-democratic tendencies have been consistently overstated, particularly by Carey. For example, as Schudson (2008) has pointed out, Lippmann never called people "incompetent." What he did was argue that the "ideal of the omnicompetent, sovereign citizen is ... a false ideal. It is unattainable" (Lippmann, 1993: 29). As for taking the "public out of politics," that "is what elections do. This is what constitutes representative democracy rather than direct democracy" (Schudson, 2008: 1033). 
Much of Lippmann's concern with democracy is rooted in a desire to make it work despite indifference from below and attempts to manipulate it from above. Charles Wellborn and Henry Steel Commager argue that Lippmann's "main preoccupation with Western thought is the question of how to replace arbitrary power with the rule of law" (Wellborn, 1969: 94). When he witnessed the rise of democratically installed tyranny in Europe in the 1930s, Lippmann saw "the old freedoms inadequate ... the brave new world of planning metamorphosed into totalitarian despotism" (Commager, 1950: 222). Seeing fascism and Nazism installed by popular vote shattered Lippmann's faith in representative democracy forever, and reinforced his fear that it could too easily be replaced by, or evolve into, tyrannyand that the machinery, such as the press, that was entrusted with preserving democracy could be forcibly turned against it, or seduced by anti-democratic forces. So, after he had demolished our notions of public involvement and direct democracy with Public Opinion and The Phantom Public, Lippmann focused, in The Good Society and Essays in the Public Philosophy, on the search for firm ground upon which to stand, and fell back on Higher Law, or Natural Law, and added a Public Philosophy built on tradition and cultural memory. If these ideas seem ethereal and quaint, they are no more so than the "utopian yearning" (Schudson, 2008:1032) represented by Dewey's belief in the Great Community or Carey's faith in the conversation of the culture. Lippmann may have started out "as starry eyed about sophisticated experts as John Dewey would be about small-town democrats" (ibid.: 1034), but by the 1940s he had lost his faith in them, just as he had in great leaders 
after he saw Wilson capitulate to the European victors' greed for reparations after the First World War.

THIS LEAVES us with the question of whether the problem lies with the indifference or inability of the public, as Schudson and Lippmann believe, with the ineffectiveness of the machinery, as Carey and Habermas argue - or with the purpose of the message and the intent of the sender, as Raymond Williams and Antonio Gramsci propose.

Williams saw, in the space between Dewey's and Lippmann's beliefs, an opening for opportunists to exploit-and a public in which no one was too smart or well informed to be fooled by the shrewd and the ambitious. He witnessed the same disruptions Lippmann and the Chicago School had observed in the Great Society of the early 20th century - but from a postwar British working class perspective, and, like Marx, he wanted to see language put to work for the good of the people. At the time, it appeared as if British traditional popular culture had been "if not annihilated, at least fragmented and weakened by the Industrial Revolution" leaving only a trace, "too small to form an alternative culture" (1983: 320). The people had lost their voice, or it had been drowned out by the machinery of industrialization. However, Williams was not inclined to trust in the good will of the ruling elite to address the situation for anything other than their own purpose-or to have faith in the communal intelligence to see through attempts to manipulate it.

To Williams, the word "masses" is a synonym for mob, and the connotation it carries is that the virtues of individuality are in danger of being overwhelmed by mass "gullibility, fickleness, herd-prejudice, lowness of taste and habit" (ibid.: 298). 
Williams would have described Lippmann's version of democracy as class democracy, a political process by which the ruling elite mobilizes the public for the sole purpose of keeping the ruling class in the business of ruling (ibid:: 299). He argues that elitists such as Lippmann fear and marginalize the masses because they represent a conversation the elite would prefer not to have. "It is also from the open record, the declared intention of the working people to alter society, in many of its aspects, in ways which those to whom the franchise was formerly restricted deeply disapprove" (ibid.: 298-299).

Williams is no more trusting of "old democrats" such as Dewey, with their blind faith in the goodness and innate intelligence of the people, than he was of Lippmann's breed of "new skeptics," who see flaws in the system and give up on it (ibid.: 312). Williams sees political indifference as a hostile and quite reasonable response to an agenda-laden message devised by the sender and forced upon the receiver. "What I have called this sullenness ... is now a very prevalent reaction to the dominative kinds of mass-communication. ... Inertia and apathy have always been employed by the governed as a comparatively safe weapon against their governors" (ibid.: 316 ). He sees the solution as being "a different attitude toward transmission" that would, more or less, involve public-access broadcasting operating in Habermas's Ideal Speech Situation (ibid.).

This is important because, in most of the discussions of the public, the assumptions are that people don't have the capacity to participate, or would if only they were invited. It was the outsiders of postwar-era British Cultural Studies, such as Williams - a Marxist, a Welshman and son of a railway worker-and his colleague, 
the Jamaican-born Stuart Hall, who were the first to suggest that there might be a problem with the sender and the message, and not with the receiver. We are all susceptible, Williams argues, to people skilled in fashioning the message to suit their purposes. To believe otherwise blinds us to the possibility that we are being manipulated and makes us even more open to manipulation. As for the uninvolved masses, Williams argues that detachment is what you get when a sullen public is confronted with persuasive monologic discourse designed to make the receiver believe that the sender's purpose is his, too. (ibid.: 316). As Peters points out,

Williams believes that both these attitudes ... communitarians and realists ... leave the door open for con artists and hucksters. ... Williams warns us against the dangers of both realism (cynicism) and blind faith (folly) in democratic attitudes. The standoff between innocence and experience only leaves the door open for exploitation by hard-headed opportunists (2003: 224-225).

Yet, unlike Marxian predecessors Max Horkheimer and Theodor Adorno, Williams never makes the "masses" the object of his discussion. In Williams's writing, the people are treated as a "we" and not a "they," and "masses" is a word used to describe the other. People are not just dupes for the controlling intelligence of the culture industries, which captivate them with "the myth of success" to the point that they demand "the very ideology which enslaves them" (Horkheimer and Adorno, 1972: 134). Rather, Williams points out that the "temptation to make a profit out of ignorance or inexperience is present in most societies. The existence, in our own, of powerful media of persuasion and suggestion make it virtually irresistible" (1983: 311). The "cheapjack," always sees his victims as stupid, and is never lacking for allies among the "old democrat," who is so sure of the nobility of the citizen that he 
never thinks to safeguard it, and the "new skeptic," who always seeks his answers in human baseness (ibid.). "We are all malleable," Williams warns (ibid.: 312), and the most powerful tool for moulding us is the media, which is yoked to a philosophy of communication that involves control and profit. When "we reject this kind of exploitation, we shall reject its ideology, and seek a new definition of communication" (ibid.).

Like Williams and Lippmann, Antonio Gramsci-looking at all this from the perspective of a fascist prison in the 1920 s - had reason to doubt the stability of modern democracy, and to suspect the media was little more than a tool for whomever could find a way to use it. He argues that, in many modern societies, there are no real differences among political parties, but that they amount to one party that has split into factions (1971). He also argues that, through law, "the State renders the ruling group 'homogeneous,' and tends to create a social conformism which is useful to the ruling group's line of development" (1971: 195). He echoes Habermas's Ideal Speech situation, though, when he expresses his faith in the wisdom of the doxa: "The correlation between individual actions and the aims of society are coercive in the sphere of positive law," but they are "spontaneous and free" when persuasion falls under the aegis of public opinion and social mores (ibid.: 196). By suggesting that the aims of the individual fall in line with society in a "spontaneous and free" way, when persuasion comes from public opinion and social mores, Gramsci implies that a social-moral imperative may be as good a way as any to organize a society. This is reflected by Lippmann in his speculation on Higher Law (1963), Carey with his faith in the "conversation of the culture" and Dewey with his Great Community-that the 
public can be persuaded to adhere to a set of social standards, through a sense of tradition and moral duty.

THERE IS yet another point of view in this discourse: that people don't need to be as informed about the issues as pollsters, politicians and journalists believe they do. They can count on the news media, the Internet and their well informed friends, family and neighbours to keep them abreast of the issues and alert them when something merits their attention. This dates back to Paul Lazarsfeld's 1940 Erie County Study, in which researchers found that there was a "two-step" flow of information, in which "a few key individuals called opinion leaders" took the trouble to study and understand issues, and form opinions about them, and then "in turn magnified this effect through interpersonal effects with their followers" (Rogers, 1997: 287).

Samuel L. Popkin takes two-step flow a bit further, to osmosis, and argues that average people are able to absorb enough information through the course of daily living to make reasonably informed voting choices, even if they have no specific knowledge of policies or issues (1991).

[P]olitical information is acquired while making individual economic decisions and navigating daily life: shoppers learn about inflation of retail prices; home buyers find out the trends in mortgage-loan interest rates; owners of stocks follow the Dow-Jones averages; people learn where it is safe to walk; and they learn about health and drugs (1991: 24).

Popkin doesn't argue that this is enough to make the difference between being ignorant and well informed. What he does say, however, is that education appears to 
have failed in deepening people's knowledge of issues, but it has succeeded in broadening the range of issues average people see as being political, and strengthening their ability to make connections between their personal experience and public events (ibid., 36). As well, he argues that voters use "low-information reasoning" to make fairly well informed choices (ibid. 44). In other words, people use "information shortcuts" to make decisions. As well, the two-step flow is working because, when the small percentage of political junkies, who follow issues closely, sound the alarm, the public pays attention (ibid.: 46 ). ${ }^{5}$

James A. Stimson breaks down the two-step flow into three groups of voters: the Passionate, the Uninvolved and the Scorekeepers. The first group consists of people who "make lifetime commitments" and never waiver from party affiliations. The second group is made up of people who mostly don't pay attention, and tend to vote according to personal interests or because someone they trust has influenced them. The final group, the Scorekeepers see political campaigns as job applications and politicians as alternating teams of managers. They carefully study the policies and promises before they vote. They have long memories and hold grudges, and they can shift public opinion over time (2004: 163-165). In this context, politics moves when enough of the Scorekeepers become convinced of an idea's viability or acceptability - the Vietnam War, civil rights, abortion, same-sex marriage-and move the vote in that direction. According to Stimson, it doesn't take very many of them to alter the course of an election. In the 1998 and 2002 U.S. presidential

\footnotetext{
${ }^{5}$ This may go some way towards explaining the popularity among a supposedly uninformed public of such issues-based satire as The Daily Show in the United States or This Hour Has 22 Minutes in Canada.
} 
contests, a change of only 637,500 votes "could have altered who was celebrating and who was vowing to do better ..." (ibid., 160).

This has interesting ramifications for a society in which news media often are more concerned with connecting with a leadership class than the general public, for two reasons: political change happens on the margins of the electorate; public opinion is moved by a small group of people who are dispassionate but well informed (ibid:: 164). Occasionally something happens, like the terrorist attacks of Sept. 11, 2001, that can draw the public into a rare informed majority, which in turn propels politics in a new direction. "[C]risis swells the ranks of those paying attention to government, and the increase comes from those who normally are neither committed nor attentive" (ibid.: 170). However, for the most part, a large part of the public prefers to tune out, and politics is moved exclusively by a small group of "non-ideological pragmatists, who trust or distrust each side equally" (ibid.: 163).

As Stimson points out, "Most people, it turns out, don't think like those who dominate our view of politics: politicians, journalists, academics. ... They don't see politics as a struggle of ideas and world views, don't emotionally commit to one side, and neither know nor care about the issue debates that so move the actors on the stage" (ibid.: 162). However, politics "does not require full time spectators" (ibid:: 15). Stimson points to further U.S. research that has shown government responds to shifts in public opinion. So, in that "change at the margin is enough to move government, democracy works" (ibid:: 171).

Still, even in these scenarios, democracy is dependent upon a free flow of reliable, trustworthy, impartial information, which members of the public - even if 
that means only decision makers or score keepers-need to make their decisions. If there is one question that unites both sides of the Lippmann-Dewey discourse, it is a concern with maintaining that flow of information.

LIKE WILLIAMS, Carey worries that public opinion can be manipulated and moulded to be leadership-friendly by polling, and that the principal forces of public life are interest groups, which are private and hidden from public view (Carey, 1997b). To restore democracy is a matter of restarting the public conversation. Like Dewey, Carey would like the press to be a tool for educating and engaging the public but-again like Williams, and like Gramsci-he regards the media as "antipopulist and antipublic" (Carey, 1997c: 245).

The "founding book of modern American journalism," Carey writes, "is Public Opinion" (ibid.). Over the course of the 20th century, he argues, the press adopted Lippmann's belief that its primary role is as watchdog and whistle blower, dealing in publicity intended to keep the experts and officials honest. This turns members of the public from subjects to objects, and transforms "freedom of speech" into "freedom of the press" (ibid.: 247). This is a concern shared by Habermas, who warns of a decline in the Public Sphere propelled by private control of the media, which makes the channels of communication more regulated and less accessible to public communication and employs strategic communication to mould public opinion to serve special interests. This situation is threatening to "refeudalize" the Public Sphere. 
The public sphere simultaneously prestructured and dominated by the mass media, developed into an arena infiltrated by power in which, by means of topic selection and topical contributions, a battle is fought not only over influence but over control of information flows that affect behavior, while their strategic intentions are kept hidden as much as possible (1992: 437).

Carey's solution is the forerunner of the citizen journalism and blogging that has become such a salient feature of communication on the Internet: public journalism, which he pioneered with Jay Rosen in the 1990s. Rather than playing the role of disinterested spectator, Carey and Rosen argue, the members of the press need to learn how to behave as citizens, and become facilitators and motivators of change in their societies. For example, rather than just writing about the deterioration of the city centre, a newspaper could convene councils involving journalists, businessmen, politicians, planners and citizens to discuss revitalization projects, and then report on the project as it progressed. To critics, this means that journalists dabble in the role of newsmaker and abdicate their role as political watchdogs and cultural mirrors. To proponents like Rosen, this an extension of ideas Dewey put forth in The Public and Its Problems, that the newspaper "must see that its own health is dependent on the health of dozens of other agencies which pull people out of their private worlds ... In theories about the public sphere, in the works of writers like Carey, in the reply that Dewey gave to Lippmann, stood the outlines of another way of thinking about the public duty of the press" (Rosen, 1999: 20).

TO BRING all this into the context of the network society in which we live, Scholars such as Barney (2004), Ronald Deibert (2002) and Pippa Norris (2000-2001) see a 
new form of politics emerging online, one made of instant and temporary associations created by converging interests. This would rise from the rubble of the nation state, which is undergoing a crisis of sovereignty, brought about by deterritorialization. Norris writes that her research indicates that the Internet reinforces globalization by "breaking down the physical barriers of space and national barriers in communication." However, it also has the capacity to act as a force for restoring balance between the various powers and the people by "fostering transnational networks linking social movements and parties in several countries" (2000: 212). The new politics is based on information, and political movements are structured as networks, with groups as nodes connected by a political flow organized and coordinated through information moving over the Internet (Barney, 2004: 120-121). Deibert goes so far as to predict the rise of "a new political species," of agents and interest groups, who will exert power on specific issues, without regard to national boundaries, or concepts of left- and right-wing ideology (2002: 134-135).

Even in the early 1990 s, there were forces on the left and the right with designs on the new politics of globalization. On the left, the push was for "a neoGramscian, postmodern politics based not on a working class party but on a shifting coalition of those fragmented social-interest groups produced, it is argued, by the decentred pluralism (to use Habermas's description) of our new consumer society" (Garnham, 1992: 370). On the right, writers such as Hayek advocated the abolition of politics in favor of "the universal pursuit of self-interest within a market" (ibid.). Now, the powers of the state have been unbundled by the free flow of global capital, and the various trade agreements that limit nations' ability to regulate economic and 
trade activity across their borders, or, in some cases, inside them (Barney, 2004: 114 115). This has created a "democratic crisis" (ibid.: 120), with the state ceding to transnational corporations, and financial and trade organizations its power to control monetary policy, trade and tariffs, and to make and enforce laws on labor and the environment. As the global market "undermines the state's capacity to deliver services, welfare states are being downsized to the lowest common denominator that keeps spiralling downwards, and a fundamental component of the legitimacy and stability of the nation state fades away" (ibid.: 117).

What is worrisome, Barney adds, is that the forces competing with the nation state for sovereignty are undemocratic, remote and unaccountable (ibid.: 118). "Politics," he writes, "has been 'capture[d]' in the space of the media." In the Network Society, politics is "a profession of public relations" in which various powers struggle "over information management and control of the 'space' constructed by prevailing media of communication, as a necessary precondition of more material forms of power" (ibid.: 122-123).

"One of the most persistent myths throughout the development of communication technology is that it would transform politics as we know it by bringing power closer to the people," yet the main use for communication technology is always commercial (Mosco, 2004: 98). The Internet certainly falls into this tradition. As Norris points out, cyber-optimists tend to regard the Internet as Agora, journal of record and Speaker's Corner all rolled into one. Advocates of direct democracy envision an electronic arena that facilitates greater use of referenda and

\footnotetext{
${ }^{6}$ Barney is citing Manuel Castells, The Power of Identity, The Information Age: Economy, Society and Culture Vol. II, 1997: 252-254.
} 
initiatives in the decision-making process and more power vested in citizens' groups and grassroots organizations (2001: 98-99). Yet, studies of Internet use seem to indicate that the levels of the uninvolved are just as high in cyber-space as in the material world. Norris's research shows that very little Internet activity is political, and most people go online for communication, commerce, entertainment and information (2001: 225).

Furthermore, online or off, we still have to contend with the same old tensions over Great Community, Public Sphere and culture. Most Internet activity is of a bonding nature: Groups are aimed at attracting the like-minded, and a visitor is more likely to exit and click on another site than to engage with a disagreeable group. Online, "it's exceptionally easy to find the niche Web site or specific discussion group that reflects one's particular beliefs and interests, avoiding exposure to alternative points of view" (Norris, 2004: 32). Norris cites the theory of a virtuous circle, which indicates that use of the Internet tends to be self-reinforcing. It provides the politically active with tools to be even more active and better informed, but the politically disengaged will be "largely immunized," because they will be the least likely to seek out political information, will likely click through most political messages they do encounter and will be unlikely to trust the messages of political Web sites. As a result, she writes, because of this tendency of Web surfers to bond with like-minded users and information sources, the Internet may increase divisions between the actives and the apathetics (2001: 230-231). It also has implications for the theory of two-step flow: if people on the Internet tend to bond only with likeminded individuals, how can new ideas or unpleasant facts break through this sort of 
self-reinforcing behavior? For example, after receiving an assortment of bizarre

Internet threats over his book on Sarah Palin, author Joe McGinnis wrote:

I sometimes wonder why anyone bothers to blog. Almost nothing anyone writes ever changes anyone's mind. Most people who read a blog already agree with the writer's point of view. The others read so they can write quick, nasty comments in response. The whole blogosphere sometimes seems like one vast game of verbal paintball (2011: 75).

Bruce Bimber, predicts an age of "accelerated pluralism"-a widening of political divisions, further fragmentation of society into special interest groups, and a continuing erosion of political institutions (1998: 134). He also sees advances in technology being "limited by the willingness and capacity of humans to engage in a complex political life" (ibid.). Thus, the level of voter apathy that Converse, Stimson and many others have discovered is likely to extend into cyberspace. "At the individual level, the Web will not alter the fact that most people are highly selective in their attention to political issues and their assimilation of information" (ibid.: 144). Similarly, Norris found, in a study of political party Web sites, the familiar pattern that online resources "mainly reach citizens drawn from political groups which already are most likely to be politically active, interested and engaged" (2003: 10).

THERE IS one, darker possibility for the new politics and the worship of technology, which Habermas pointed out in the late 1980s: that the aim may be the "depoliticization of the mass of the population."

To the extent that practical questions are eliminated, the public realm also loses its political function. ... Its organization continues to be a 
problem of practice linked to communication, not one of technology, no matter how scientifically guided. ... The substitute program, which legitimates power today, leaves unfilled a vital need for legitimation: how will the depolitization of the masses be made plausible to them? ... [B]y having technology and science also take on the role of ideology (1989b: 253).

Eric Alterman (2008) argues that the stresses that exist between the network society and the mainstream media can be interpreted as an extension of the positions of Lippmann and Dewey. The mainstream media deals in epistêmê and plays the role of Lippmannian gatekeeper, speaking down to the mass of society and holding the powerful accountable. Meanwhile, the wild, unorganized, interactive Internet puts the doxa back into democracy, acting out Dewey's and Carey's concept of the conversational society - and creating that "neo-Gramscian" system of public opinion and discourse, with a constantly mutating web of affiliations, alliances and ad hoc power structures.

In this chapter, I have tried to draw a rough map of free speech, public opinion and public responsibility from the past to the present, rooted in the discourse that has grown up around some writings by Lippmann and Dewey, dealing with whether public opinion is unreliable and capricious and needs to be controlled, or represents the struggle of a society to forge itself into a community. I have also attempted to place free speech into this context: that a tradition stretching back hundreds of years connects communication to public life, and that this connection is an essential ingredient of a democratic society. Open debate, Natural Law, the free market of ideas, the Ideal Speech Situation and the concept of a Public Sphere can be taken as representing a striving to define free speech and to place it beyond the reach of the 
opportunists who would subvert it and manipulate it, as well as the tyrants who would silence it. All, more or less, embrace the idea that open communication is a natural state for humanity, and that censorship and repression, despite their omnipresence, are deviant. At the same time, the concern over the ability of special interests to bend communication to their will also stretches back hundreds of years. From Hobbes and Burke to Lippmann and Williams, there has been a legitimate fear that persuasive speakers can combine with an uninformed audience to create tyranny or chaos - that today's majority has the power "to deprive tomorrow's majority of its rights" (Lippmann, 1963: 56).

However, Williams represents a middle ground between Lippmann's cold, elitist vision and Dewey's idealism. He warns that there always will be the opportunists who look for profit at other's expense through what Habermas called "strategic action"- which seeks personal advantage in a situation and uses whatever tools are at hand to gain that advantage.

Williams probably has more in common with Lippmann than he would ever have cared to admit. Though he spent his entire life working at it, Lippmann never did come up with an answer to the problem of how to organize society so that it functions for the good of the citizens and not just to answer their demands, or how to govern by telling the people what they need to know, as opposed to what they want to hear-and to ensure that demagogues do not prosper at the expense of the people, by appealing to their self interest and baser instincts. As Lippmann puts it at his most pessimistic:

The environment is complex. Man's political capacity is simple. Can a bridge be built between them? The question has haunted political 
science ever since Aristotle first formulated it in the seventh book of his Politics. He answered it by saying that the community must be kept simple and small enough to suit the faculties of its citizens. We who live in the Great Society are unable to follow his advice. The orthodox democrats answered Aristotle's question by assuming that a limitless political capacity resides in public opinion. A century of experience compels us to deny this assumption. For us, then, the old question is unanswered; we can neither reject the Great Society as Aristotle did, nor exaggerate the political capacity of the citizen as the democrats did. We are forced to ask whether it is possible for men to find a way of acting effectively upon highly complex affairs by very simple means (1993: 69).

Since Lippmann's time, The Great Society has grown noisier, more violent and more confusing, and it has become easier for individuals to tune it out. Further complicating things is that fact that we and our governments have ceased to define people as citizens. We have become consumers or clients-objects of political power, rather than the subjects of it. Lippmann and Schudson say it is a waste of time to expect involvement from average people, Lippmann out of despair or thwarted idealism, Schudson out of realism. For Lippmann, an uninvolved public is the problem. To Schudson, the trouble is an information overload with which no one could hope to cope - at least no one who wishes to have a life.

Schudson (1995) argues that what is needed is a press that acts as a watchdog, forcing the powerful to behave as if someone is always watching them, and standing ready to bark when something happens that requires the attention of the general public. But he wrote that in 1995 , just before the explosion of Internet information and the breakdown of the mass audience, which has seen the mainstream news media become the main purveyor of reliable information online - yet unable to find a way to earn a profit from it, and thus sliding into financial jeopardy. 
Carey argues that the public must be engaged in the conversation of the culture, that the media needs to use narrative to illuminate, educate and motivate its audience. Like Dewey, he no more believes in an impartial or watchdog press than in a phantom public. Carey argues that the first steps in restoring the power of the press to serve and engage the public are for the public to reclaim free speech from the press and politics from the special interests - that is, make the public voice the people's voice and the political will the people's will.

Williams argues that people naturally become political when their direct interests are involved and, when they perceive irrelevance, they tune out, their sullenness and detachment the only tools they have with which they can express their disapproval. Always, there is the need to defend against the "cheapjacks," who never cease playing the angles and looking for ways to turn the public into a "swinish multitude" that can be driven to market.

There have been many formulas to protect against this, from Hobbes's (2001) warnings against abuses of language to Habermas's Ideal Speech Situation. Even Milton was comfortable with restrictions on free speech when it came to heresy, blasphemy and obscenity (Guss, 1991). In a liberal society, Peters (2005) argues, we have to be willing to tolerate abhorrent ideas if we mean to preserve freedom of speech-but that doesn't mean we have to give them equal time or equal credence. We can't eliminate the darkness and we deny its existence at our peril, but we can't give ourselves over to it. Our best defence is critical thinking. We live in the light and keep a nervous eye on the darkness. Peters calls for a drift to the "radical center," a place where "we can oppose both moral nihilism and capitalist abuse [and] shudder at 
both the pornography industry and the censorship of state or church" (ibid.: 293). "Radical centrists," he writes, "defend liberty and fear for evil" (ibid.: 292). Like Lippmann and Williams, Peters implies that the struggle is unending because any final solution would put an end to that which it sought to defend. If we are to have freedom of speech, we must live with, and in constant opposition to, those who seek to exploit it.

Yet, the problems posed by Lippmann in The Public Opinion and The Phantom Public, and by Dewey in The Public and its Problems, have been growing more acute.

Postwar French thinkers such as Roland Barthes and Henri Lefevre looked at the mass media and declared that, rather than a Great Community, we had conspired to create a mystified society, and that a community can be great and still be dull and acquiescent. In this mystified society, a confluence of political, media, culture industry and marketing messages sell a way of life that "privatizes consciousness and promotes a sense that experience is unique to the individual, and masks the awareness of social context" (Kelly, 2000: 86). So, if free speech is natural, it would appear that the tendency to try to profit from it is, too, and there will always be those who seek to turn the Public Sphere into a supermarket. As Nader put it:

A strong belief in free will often impedes understanding of how lives are changed by cultural practices that are external to the individual and intended to modify individual behavior, for example, through political propaganda or economic marketing. Anthropologists witness and experience the construction of culture for financial gain. We are a marketing society (1995: 721). 
Like Horkheimer and Adorno, Barthes argued that the audience is a participant in the process of mystification (Kelly, 2000), that people willingly fall into a false consciousness by buying into the culture that enslaves them. Marketing involves not just a vendor, but a buyer as well, and this leads to the question of whether media consumers are involved in a great democratic discourse, or are tuning in simply to be entertained and reassured. In Barthes's and Lefevre's eyes, it wasn't George Orwell who proved to be the prophet, but Aldous Huxley, who predicted a rigidly stratified society filled with a population made dimwitted and lazy by drugs and sex. Control can more easily and completely be exerted by the promise of pleasure than the threat of violence.

This raises the question of whether Dewey's Great Community can be reconstructed as a place we go to have our prejudices reinforced and our preconceptions affirmed-and if that is how we form the new Common Sense. Barney asks whether the Network Society is "radically discontinuous or radically continuous" (2004: 39). It is both: radically continuous because it's an extension of the Public Sphere; it is another space we can fill with our culture and in which we can live. It is radically discontinuous because, for the first time, we have an artificial space we can inhabit and tailor to suit our senses and sensibilities. Also, Barney, Norris and Deibert see change in the tendency for people online to coalesce around issues and to shun ideology. Norris's research indicates that the Web is a bonding technology and not a bridging one. If we want to tune out everything except football, comic books or Japanese films, we can. If we want to join a strange little group of like-minded people with whom we can bond, that's our right. However, this does 
indicate a breakdown of the concept of mass audience and perhaps a public as we have come to know it. Whether it means we are becoming a crowd remains to be seen, but it is hard to see how cyberspace will ever lead people to connect with people they don't want to know or things they don't want to think about. In other words, it is unlikely that we'll find Dewey's Great Community online_or that, if we do, there is any guarantee that we will like what we see.

THE NEXT chapter looks at the popular press over the two centuries or so that it has existed as a business, and as a professional occupation: from the rise of the penny press and the spread of literacy through the lower levels of economic society, to the embracing of objectivity as an industry standard and the concurrent evolution of the punditocracy, to the growth of the chains that came to dominate a news media that, through the 20th century, were seen to be growing more beholden to commercial interests and less dedicated to serving the public. 


\section{Steel, ink, flesh \& money}

ONE OF THE more famous quotations on the subject of the press is Thomas Jefferson's statement that he would prefer "newspapers without government" to "government without newspapers" and would legislate that "every man receive those papers and be capable of reading them" (Cited in Nerone et al., 1995: 47). Less often repeated is what Jefferson had to say about the fourth estate after he had spent some time as its target: "The man who reads nothing at all is better educated than the man who reads nothing but newspapers" (Cited in Jones, 2009: 62).

Jefferson's comments serve as a nicely concise model of our mixed feelings about a free press: something necessary to maintaining the free flow of information in a democratic society, yet often irresponsible, aloof and insensitive. Yet, it's important to note that Jefferson was not talking about the press as we know it, but about something that was more like talk radio, the all-news networks or the blogs of today.

What we consider "news" has evolved over the past three centuries, along with the business and technology that make it. Most newspapers in the early days of the press-the 18th and early 19th centuries - were partisan journals of ideas and argument, produced for the social and political elite. Schudson describes them as "histrionic, cheerleading, one-sided, rationalizing, ridiculing and disparaging" (2008: 1037). So, Jefferson was praising, and condemning, "the newspapers' capacity as a forum for debate (and sometimes slander), not exposé" (Shafer, 2009d). And he was 
talking about the conflict of opinions and the marketplace of ideas, not raw information.

This chapter samples selected sources on the history of publishing, the media and journalism with the aim of creating a continuum into which we can place the examination of present-day business, technology and craft of Chapters 4,5 and 6 . It is by no means a comprehensive examination of the history of journalism. Rather, it points to specific milestones to provide a brief compilation of precedents. By exploring the evolution of the Canadian, U.S. and British press, we can establish that journalism has evolved over time through many business models and aesthetic and literary styles, driven by public demand, technology, social conditions and business opportunity. Also, by putting the technological and commercial development into some kind of historical perspective, looking at how technology has repeatedly helped transform business and craft, we can place into context much of the current upheaval in the field.

This narrative is by necessity somewhat rambling, because the parallel technological, financial, literary and aesthetic developments intertwine to form one story, and the threads don't always unravel chronologically. Throughout the history of the news media, evolution in one area has consistently sparked developmental response in another. For example, the spread of literacy in the United States created an audience for a mass media that was enabled by the development of the steam press and financed by mass advertising - and this gave birth to literary and investigative traditions of modern journalism. 
THE FIELD OF journalism is barely three centuries old-and journalism as we know it is a little more than half that age. It has only been in the past 140 years or so that gathering facts and writing about them have come together to form a type of employment. Until the mid-19th century, newspapers in the United States, Britain and Canada were dependent on political patronage and closely associated with specific political parties - and often filled with essays that might have looked more at home in a journal of ideas than a modern newspaper. In the latter part of the 19th century, spurred by the rise in literacy among the general populace, the press evolved into a commercial enterprise built on a unique two-tier manufacturing process: news is moulded into content that is sold to readers, who are collected into an audience, which, in turn, is sold to advertisers.

As several commentators (Kesterton 1967, Schudson 1973, Starr 2004, Teel 2006, McChesney and Nichols 2010) have pointed out, the fortunes of North American journalism over the years have been largely dependent on technology and government support. New technologies and cost-saving developments have repeatedly made for a favorable environment for growth and evolution not just of the business, but of the craft of journalism as well: from postal systems to rotary presses, to steam presses, to the telegraph, to stereotyping, to radio, newsreel and television, to cold type, photo engraving and offset printing, to computer pagination, to online publishing. As well, government support-advertising, postal subsidies, tax breaks and legislative protection-has long helped ensure the financial health of the news media.

As Elizabeth Eisenstein points out, before the 18th century, providing news 
was a function of the Church: "As communion with the Sunday paper has replaced church-going, there is a tendency to forget that sermons had at one time been coupled with news about local and foreign affairs, real estate transactions, and other mundane matters" (1979: 131). Over the course of the century, however, lay printers took over the dissemination of secular news, and became the earliest newspaper publishers: one-man newsrooms for whom "the dictum 'nothing sacred' came to characterize the journalist's career" (ibid.). Thus, the news severed itself from the Church and aligned itself with politics and business, in tandem with what was occurring across Western society at the time. Interestingly, what we see as the birth of the mass media was at the time regarded as a divisive force-much as the Internet is viewed in some quarters today. Early critics argued that the evolution of print media implied a shift in the way people participated in public life, from personal connection as part of a community to detached involvement as a sovereign citizen. "By its very nature, a reading public was not only more dispersed, it was also more atomistic and individualistic than a hearing one" (ibid.: 132).

Over the course of the 18 th century, monthly journals gave birth to weeklies, which in turn gave birth to dailies, and it was along with the introduction of reliable mail service in Europe and the United States that the earliest forms of journalism emerged. Advances in printing, the rise of the nation state, the expansion of commerce and religious conflict had created a sufficiently turbulent environment for "more autonomous forms of communication even before free expression received legal protection" (Starr, 2004: 23). In other words, the conversation of the culture was well under way before printing technology was adapted to provide a medium for it, 
and before governments were pushed to create mechanisms to protect it, such as the First Amendment to the U.S. Constitution.

In the United States, publishers benefited greatly from a federal government mandate established in 1792 , which required the postal service to carry all newspapers that wished to use the system, and to offer them special low rates. This, combined with the absence of a stamp act on ink and paper, created very favorable economic conditions for the rise of newspapers. In the late 18 th and early 19 th centuries, the rapid development of the United States Postal Service created an atmosphere for an equally rapid growth of American newspapers. Starr notes that, between 1790 and 1835, the number of American newspapers grew from 106 to 1,258 (2004: 86). At the same time, the new U.S. government had established an extensive postal system. "By 1820 , for example, there were 443 post offices spread through the state of Massachusetts (which then included Maine)," and by 1830 , the USPS was delivering roughly a quarter of all newspapers consumed in the United States (ibid.: $89-90)$. By 1830 , the postal service was delivering 2 million more newspapers than letters; two years later, 95 percent of the weight of all mail consisted of newspapers, yet accounted for only 15 percent of revenue (ibid.: 90).

MEANWHILE, in Canada, the earliest newspapers "came as a transplant from the New England colonies" (Kesterton, 1967: 1). Canada's first newspaper was the Halifax Gazette, founded by a Boston publisher named Bartholomew Green in 1752. Similarly, in Quebec, the first English paper was the Quebec Gazette, founded by a pair of Philadelphia printers in 1764 , a year after the Treaty of Versailles ceded 
Quebec to Great Britain (ibid.: 2). By the time of the Revolutionary War, a decade later, there were newspapers publishing in all of what would become the six eastern provinces.

However, the Canadian newspaper industry was much slower to develop than its U.S. parent, partly owing to a rudimentary postal system that offered no subsidies for newspapers. As of the 1830 s, between the Ottawa Valley and the Atlantic coast, "there were more than 100,000 people, but only seven post offices ... rates were high, and the volume of postal communication was low" (Starr, 2004: 89). With small populations and low literacy levels in the Canadian colonies, circulation was tiny and advertising spare and primitive. So, early Canadian newspapers were highly dependent on government patronage - in the form of contracts to print various forms, edicts, announcements, pronouncements and proclamations. Kesterton describes the "pioneer papers" as "innocuous" in character, "unremarkable" in appearance and, since they were published in colonies under authoritarian rule, more or less subservient to the wishes of the sovereign (1967: 7-9). Still, the Canadian newspaper business grew, though not as robustly as its American counterpart. There were 20 news sheets published in what were to become Central, Eastern and Atlantic Canada in 1813 ; by 1857 , there were 291 (ibid.: 11).

This is a pattern of development that would persist through the 19th and 20th centuries, with Canada lagging behind and, more or less, echoing developments in the United States. However, there was one key difference, the constant chafing against a larger, dominant culture: first Britain, then the United States. At first, this took the form of a press polarized by foreign rule, and later by a growing demand for 
protectionist policies to keep Canadian media companies from being absorbed or drowned out by their larger, wealthier and stronger neighbors to the south.

The North American press of the 18 th and early 19 th century is routinely described as having been made up of partisan, party-controlled newspapers competing for readers' hearts and minds. The reality was more complex. In the United States, "Is]ome editors still adhered to the old ideal of a neutral, open press, and many others were partisan only in the sense of identifying with a party's viewpoint" (Starr, 2004: 84). In Canada, this was tinged with a growing loathing among many of the colonials - particularly the francophone ones of Lower Canadafor the governors sent from England to run things. As it had done in the United States, a growing movement for responsible government was finding voice in the newspapers of the day-countered by another for the status quo of colonial rule. As a result, by mid-century, Canadian "newspapers were labelled according to the stands they took on the responsible-government issue. As views became increasingly doctrinaire, most of the important journals became known either as Reform or antiReform" (Kesterton, 1967: 14).

The few commentators on the history of Canadian newspapers have pointed out that it was this political polarization that gave birth to the tendency toward chain ownership that has marked the Canadian industry throughout its history. The creation of every anti-Reform publication in an important centre created a need for a Reform journal to counter it. "Early newspapers were powerful weapons in a perpetual battle but they were not necessarily implements of public opinion as later ones were, for they most often preached to the converted" (Fetherling, 1990: 78). Political rivalries 
made for commercial warfare, and the "stronger newspapers gobbled up the weak ones, to the point where only a handful remained to fight for control of the expanding and immensely wealthy markets" (ibid.: 97).

IN THE United States, the 1830 s were a period of revolution in journalism that "led to the triumph of 'news' over editorial, and 'facts' over opinion, a change which was shaped by the expansion of democracy and the market, and which would lead, in time, to the journalist's uneasy alliance with objectivity" (Schudson, 1978: 14). Though by this time the majority of newspapers in the United States were weeklies, the daily newspaper had begun its rise. In 1830, the United States had 650 weeklies and 65 daily newspapers; 10 years later, there were 1,141 weeklies and 138 dailies (ibid.: 13). But it wasn't statistical growth that changed the face of the newspaper business. Rather, it was something born out of technology and demographics: the penny press.

In Canada, the papers were still engaged in debate over responsible government, with the major innovations being that they had begun to report on Parliament and to devote space to local news. However, when it came to publishers aiming their product at newly educated masses, Canada was slow to adapt. Perhaps this was because the country, like Europe, trailed the United States in education, and had yet to experience the kind of huge influx of working-class immigration that was flooding the U.S. Eastern Seaboard. By the 1850 s, the illiteracy rate in the United States was 10.7 percent among white Americans and, in the general population, 22.6 percent. In comparison, approximately 60 percent of the European adult population 
could neither read nor write (Starr, 2004: 105). Though literacy was rising sharply in English Canada, the rate was still lower than in the United States and, in Quebec, illiteracy stood at an appalling 73 percent (ibid.: 106). So, in Canada, newspaper publishing remained a business for gentlemen aimed at influencing other gentlemen. The Canadian newspaper publisher remained grounded in "political passion, rather than commercial desire to attract the eye of potential readers" (Kesterton, 1967: 18).

However, south of the border, a massive change was sweeping the business. In the $1820 \mathrm{~s}$ and ' $30 \mathrm{~s}$, most U.S. states had moved to extend the vote to all adult white males. Thus there was a large new class of citizen, with "new reasons to pay attention to the news, and political parties had new reason to pay attention to them" (Starr, 2004:130). This meant a new clientele for the press, which moved quickly to address this audience, with the founding of the New York Sun in 1833, followed in the next two years by the creation of competing journals in New York and similar ones in Boston, Philadelphia and Baltimore. These were the "penny papers," so called because they sold for one cent a copy, rather than the usual six cents. Their focus was on news, and local news before national and international. They aimed to entertain and agitate as much as to inform and influence, and their target audience was that mass of newly educated middle and lower classes that were swelling the cities of the East.

The objective of the penny papers was to make a profit and, unlike the traditional papers, they relied more on newsstand sales than subscriptions for their circulation-and, since they were priced for shallow pockets, their success depended on their ability to build large circulation. As a result, the penny papers were 
responsible for several innovations that led directly to the modern omnibus daily newspaper-not the least of which was the front page as we know it. From a dull collection of announcements, ads and letters, the front page became, as one Canadian Prairie publisher put it, the "display window of [the] store of news ... filled with good samples" (Cited in Sotiron, 1997: 19). So, ads, editorials and notices vanished from the new front page, to be replaced with pictures, stories and headlines designed to grab and hold a reader's interest. Newspaper editors became more than fixers and style policemen; they also became advertising copywriters, marketing their wares to the masses.

Another thing this new mass audience created in the press was the concept of economies of scale, and this "opened up opportunities for a journalism of a different kind" (Starr, 2004: 131), one that was highly competitive and technologically advanced.

The penny papers aggressively sought out local news, assigning reporters to cover the courts and even "society." They also actively solicited advertising and engaged in vigorous competition to print the very latest news. Their business-minded assertiveness made penny papers the earliest adapters of new technologies. In 1835, already selling twenty thousand copies a day, the New York Sun became the first newspaper in the country to purchase a steam-driven press. Another penny paper, the Baltimore Sun, made early use of the telegraph and helped encourage its public acceptance (Schudson, 2003: 76-77).

When The Sun was founded, in 1833, there were 11 newspapers in New York, with a total circulation of 26,500 (Starr, 2004: 130). Two years after adopting the steam press, The Sun was selling almost that many copies alone. It was the penny press that gave birth to what we think of as modern journalism, and it was a "democratic market society" - the "replacement of gentry rule by mass democracy"- 
that gave birth to the penny press (Schudson, 1978: 57).

AS FOR WHAT we consider modern journalism, that was a bit slower to develop, but it definitely had its roots in the penny papers. Before them, the average newspaper was a small business run by a publisher-editor with a few, usually unpaid, correspondents contributing essays or letters. This gave way to large, more hierarchical organizations, in which reporters, for the first time, were employed to gather and write about news. "As news was more or less 'invented' in the 1830 s, the reporter was a social invention of the 1880s and 1890s" (ibid.: 65). And the interview - the central activity of modern journalism - wasn't introduced until the 1860s.

Interviewing, all but unknown in 1865, was widely practiced by 1900 . By World War I, it was the mainstay of American journalism, although it was still rare in Europe.... It fit effortlessly into a journalism already fact-centered and news-centered, rather than devoted to political commentary or preoccupied with literary aspirations. Interviewing was one of the growing number of practices that identified journalism as a distinct occupation with its own patterns of behavior... By the 1920s, this pattern produced a self-conscious professionalism and ethic of objectivity (Schudson, 2003: 81-82).

Another creation of the penny press was the inverted-pyramid style of writing, in which the facts are presented in declining order of importance, and in which the narrative moves from generalities to specifics-like putting the punch line first in a joke. It also involves punchier, more direct writing: shorter sentences, active verbs, and sparing use of adjectives and adverbs. As a New York Times news executive put it, journalism was coming around to the belief that "stark fact, simply told was more powerful than any purple writing" (Teel, 2006: 45). Two main reasons are commonly 
given for this development: that readers' interest tends to trail off and with this style of writing they could read part of a story and still be reasonably well informed; that it made stories easier to trim to remove overset or to accommodate late ads. However, from a cultural perspective, the inverted pyramid also fit well with "a world of increasingly independent and cocky journalists who were prepared to name on their own authority what aspect of the news could be judged most important" (ibid.: 185).

Investigative reporting also came into style in the late 19th/early-20th century. Known as muckraking, it was the work of zealous and aggressive journalists supported by a new media capitalism run by "wealthy upstarts at odds with respectable society" (Starr, 2004: 258). The term "muckraking" was coined in a speech by U.S. President Theodore Roosevelt, who compared the journalist to the man with the muck rake from John Bunyan's Pilgrim's Progress. This was a man "who could look no way but downward, with the muck rake in his hand ... who in this life consistently refuses to see aught that is lofty, and fixes his eyes with solemn intentness only on that which is vile and debasing" (Roosevelt, 1906).

As a Progressive, Roosevelt had been at first sympathetic to the work of muckraking reporters - but, like Jefferson, he changed his point of view when they started to turn on him. The Progressive movement called upon government to will into being a new order that would wipe out the corrupt political bosses, rein in the trusts and tax the robber barons. The muckraking journalists have been described as being "the watchdogs" of Progressivism (Steel, 1981: 36). However, they also were the main weapon of "a new level _or at least a new form-of power available through the medium of journalism" (Starr, 2004: 258). Muckraking later became a 
mainstay of such magazines as McClure's and Everybody's - where a young Walter Lippmann began his career apprenticing with the investigative journalist Lincoln Steffens ${ }^{1}$. But it got its start in the pages of such Pulitzer and Hearst papers as the New York World and the New York Journal-American. For obvious reasons, this style of reporting had great resonance with the middle and working classes, the main clientele of the penny press.

Exposing the corruption of political machines, detailing the stranglehold of the giant corporations, crying shame on the cities where immigrants and blacks were exploited, these journalists roused the middle-class conscience and made reform a mass movement (Steel, 1981: 36).

IN BRITAIN and Canada, the development of a popular press lagged by roughly half a century. By 1872, the largest newspaper in Canada was the Toronto Globe, with a circulation of around 20,000 (Sotiron, 1997: 5). Owned, published and edited by Reformer and "polemicist" George Brown, the Globe was "required reading among the educated and business elites" (Hayes, 1992: 46-47), and was by no means intended for a mass audience.

It wasn't until the beginning of the 20th century that Canadian newspapers began to reach a public, as opposed to the kind of select constituency the Globe spoke to. Perhaps not coincidentally, by 1891 , the literacy rate in English Canada had reached 85 percent (Sotiron, 1997: 39), and the popular press had begun to emerge. Canada's first penny papers - not surprisingly in the country's largest cities and the main gateways for immigration - were The Montreal Star and Toronto's Telegram

\footnotetext{
' Lippmann quickly broke with the muckrakers, arguing in Drift and Mastery that the job of engineering society should be left to technicians and statesmen who work dispassionately and without appealing to the baser instincts of the public.
} 
and World. The Star was the largest paper in the country, with a circulation of 52,600 in 1899 (ibid.: 5). "With the exception of these dailies in Toronto and Montreal, newspaper content was dominated by political news, verbatim reports of parliamentary debates, dry commercial information and accounts of events in foreign places" (ibid:: 17).

By the 1910 s, the situation had changed drastically. Canada had begun to industrialize, and newspapers finally began to operate as business ventures. However, some 60 years after the birth of the penny press in the United States, most Canadian papers were still organized the way they had been since the late 18 th century.

Until the 1890s newspaper operations were usually modest even in the largest cities, and this was reflected in news coverage and in the number of people they employed. A commentator on the two Vancouver newspapers of the 1890 s noted that "there was a lack of balance about them, a lack of variety and a lack of the features that are considered necessary to-day to attract and maintain reader interest. There was little world news in either of them, and the local news ran quite largely to politics with appallingly long reports of political meetings and sessions of the legislature and quite often of court proceedings, and City Council sessions." In 1884, one account noted, most newspapers only needed "an editor and two or three other men" (ibid.).

The Canadian flag-bearer for the aggressive, sensationalistic style of the penny press wasn't even founded until 1892. That was the Toronto Daily Star. It started life as a strike paper founded by printers who had walked out of the Toronto News, which had billed itself as a "paper for the people" (Harkness, 1963: 28). The Star floundered for the first two decades of its existence, going through four owners and barely amassing a circulation of 7,000 by 1899 (ibid.: 24). "[U]nrespected, uninfluential, and almost unread" (ibid.: 20), it was Toronto's "smallest, poorest and most discredited newspaper" (ibid.: 24). That changed rapidly after, in 1899 , the 
paper was bought by a consortium acting on behalf of Prime Minister Wilfrid Laurier, who wanted a second Liberal newspaper in Toronto-to complement The Globe (ibid: 19). The Star was placed in the editorial hands of Joseph E. Atkinson, who agreed to accept the position on condition that the paper be "conducted solely in its own interest as a newspaper enterprise ... hampered by no other considerations" (ibid.: 21). On the 100th anniversary of this refounding of the paper, Star publisher Beland Honderich credited Atkinson with inventing the Canadian mass-circulation newspaper. When Atkinson took over The Star, Canadian newspapers tended to be serious or popular, and he believed "it would be possible to develop a newspaper that would be soundly popular in its appeal and at the same time find ample room for the presentation of the serious interests of human life" (Honderich, 1999). In the 1930s and '40s, under the guidance of Atkinson, who had risen to the post of publisher, and his editor-in-chief Harry Hindmarsh, The Star grew to become the largest newspaper in Canada, and "the last home of razzle-dazzle journalism."

A penchant for cheesecake, huge headlines, full-page pictures, charitable activities such as the Fresh Air Fund and the Santa Claus Fund, startling newspaper stunts, and off-trail and frequently left-wing causes gave the paper a liveliness and variety that readers could not ignore (Kesterton, 1967: 86).

The Star's blend of serious political commitment, muckraking and sensationalism was copied directly from Joseph Pulitzer's New York World, which, through the 1920 s, matched human interest, crime, social crusading and city news with one of the most respected editorial pages in the United States- - edited by Lippmann, writing "in shades of grey for an audience that wanted black and white" (Steel, 1980: 218). The Pulitzer and Hearst papers in the United States had long since 
discovered that there were extraordinary profits to be made in promoting the social causes of the common person, and in exposing and exploiting the indiscretions of the rich and famous. In the same way, The Star served the needs and interests of Toronto's swelling immigrant population. If The Globe was the paper of the protestant ruling elite, The Star was the daily that spoke to the working class Jewish and Catholic populations, which were growing rapidly (ibid.: 59). Although the New York World folded in 1929, The Star flourished through the 20th century, as "a truly populist paper ... a potent mix of commercialism and piety" (Hayes, 1992: 59).

In such cities as New York, Boston, Philadelphia, Baltimore, Montreal and Toronto, it was not just an act of social conscience to embrace the working class. It was good business. So, because the penny papers in these places sought a working class clientele, they "endorsed policies and political causes that working people believed in. Whether their sympathy for the masses was sincere or not, sponsoring the cases of the relatively powerless served their interests" (Schudson, 1995: 5). The way Pulitzer put it was:

An able, disinterested, public-spirited press, with trained intelligence to know the right and courage to do it, can preserve public virtue without which government is a sham and a mockery (Cited in Teel, 2006: 1).

As in Canada, the British popular press was slower to evolve than it had been in the United States. Asa Briggs and Peter Burke credit its rise to the Education Act of 1870 , which set up schools that brought literacy to "hundreds of thousands of boys and girls," creating "a buoyant demand for reading matter very different from that on offer to an educated public" (2005: 159). And this created what the literary critic Matthew Arnold described as a "feather brained" style of journalism that was aimed 
at attracting the newly enfranchised populace, who were more interested in crime, entertainment and scandal than the issues of the day (ibid:: 160). While the penny press represented the democratizing of information in North America, in Britain, it created a press for the ruling class and another for the lower classes, a schism that persists today, between "quality" journalism and the tabloid press.

Similarly, the most common argument for the rise of the penny press in the United States is expanded education and a high literacy rate, Schudson notes (1978). However, he raises the intriguing possibility that technology may have created literacy through increased printing, in the form of advertising signage, leaflets and publications that people had come to need to help them navigate the Great Society. In other words, "people learn to read when reading becomes important" (ibid.: 36).

WHATEVER the cause, the spread of literacy across class lines might have been expected to at least eventually democratize the press. However, there is another interpretation: that literacy gave rise to a media that herded people into a consumer corral, as "the ideal of an informed public [gave] way to the realities of the market" (Briggs \& Burke, 2005: 159).

Through the commercialization of communication in the late 19th and 20th centuries, Habermas argues, capitalism, which had demolished feudalism, began to "refeudalize" the Public Sphere by reversing the process of public opinion from one that is formed by private citizens acting as a community to one formed when private enterprise frames the discourse, and then - through public relations, advertising and a cooperative news media-impresses that discourse onto the crowd (1991: 195). 
Habermas argues that this has led the press from being a manifestation of culture, a means of education and a transmitter of the public opinion to a seller of entertainment and a manufacturer of a debased consumer culture. This plays into the various theories of hegemony, which, as we saw in Chapter 1 , define modern society as a "marketing culture," in which the aim of all communication is the sale of a product, an idea or a belief, creating what critics on the left have called a state of false consciousness, or "mind colonization" (Nader, 1997: 720).

At the same time, Habermas argues, the newsroom was undergoing a refeudalizing process of its own, in which the roles of editor and publisher changed from one of equals to "one of employer and employee" (1991: 183), placing commerce in the ascendant position and communication in a subordinate one.

The separation of public and private spheres implied that the competition between private interests was in principle left to the market as a regulating force and was kept outside the conflict of opinions. However, in the measure that the public sphere became a field for business advertising, private people as owners of private property had a direct effect on private people as the public. In this process, to be sure, the transformation of the public sphere into a medium of advertising was met halfway by the commercialization of the press (ibid:: 189).

Schudson argues that there is a flaw in Habermas's thinking in the context of journalism: These arguments fail to take into account that the commercialization of the press is only half the story. "Journalism as an occupational field became professionalized at the same time that it became commercialized as a business enterprise" (2003: 69). This professionalism armed journalists with stronger convictions, greater interest in the way their publications and newscasts were run and a more powerful ethical foundation for their demand to have a say in the forming of 
editorial policy. And this, Schudson argues, acted as a counterbalance to commercialization.

On the other hand, it also has been argued that the news workforce never was entirely defeudalized.

As we have seen, the newsroom evolved from "a single entrepreneur, usually flanked by a small coterie of foremen and managers who exercised power personally" to a complex hierarchical organization (Solomon, 1995: 119). The one thing the two organizations have in common is that they are designed to exploit journalists' feelings that their work is a "sacred calling" by claiming "a public service mandate that allowed publishers to submerge their profit motive within an appeal to their newsworkers' sense of duty" (ibid.). Although unionization and a heightened sense of professionalism in the business combined to improve conditions for newsworkers through the 20th century, the pressure on profits created by the Internet has filtered down to a shrinking and beleaguered workforce. "New technologies and media mergers improve newspaper corporations' leverage over newsroom workers" to the extent that their situation is reverting back to that of the 19th century, when newsworkers were poorly paid - often less than so-called "crafts" workers - badly treated and enjoyed no job security:

In the late 19th century, U.S. capitalism's transition to a corporate phase drove the commercial press's development, enlarging newsroom staffs and fuelling an increased division of labour. At the same time, the rising costs of owning a newspaper were moving ownership of the means of production beyond the financial reach of most newsworkers. Underlying these changes in political economy was a long-standing ideological component, one that infused newswork with a thoroughly individualistic, middle-class ethos. Caught between their public service ethic and their self-image on the one hand and their employers' capital accumulation strategies on the other, newsroom workers suffered. 
Today, as corporate capitalism becomes increasingly global, newsroom workers again face worsening work conditions. So, like their counterparts of more than a century ago, today's newsroom workers increasingly are coming to view their work as combining a sacred trust with a temporary job. The consequences for the public sphere-in a country that identifies itself as having a well informed citizenry that is becoming even more so, by moving onto an information superhighwayare unpleasant, at best (ibid:: 131).

As the term "information highway" indicates, that was written in the mid1990s, before the Web was recognized as a three-dimensional space-a new Public Sphere - rather than a linear medium, and long before the "broken business model" that plunged the industry into its current state of despair. As we shall see in subsequent chapters, the consequences of technology on the newsroom workforce have been anything but positive in terms of quality and quantity of employment. However, what Solomon failed to foresee was that the new technology would also provide terrific tools for gathering information and communicating it, and would reduce the cost of publishing to the point that, once again, anyone can found a news organization. In the corporate setting, though, Solomon was tremendously prescient: If anything, it has made the conflict between sacred trust and income more pronounced.

IF THE 19TH century was characterized by the rise of commercialization, the development of professionalism and the adoption of technological innovation, the 20th was marked by: consolidation of ownership; a fixation on objectivity and professionalism; the continuing adoption of technological innovation, and a fear that technology had begun to turn against the print media. In terms of circulation, the 
latter half of the 20th century was a period of long decline, even though it was also a period of constant revenue growth. In Canada and the United States, "the 20th century newspaper story ... is a story of consolidation and centralization. Its inevitable result is the replacement of the multi-newspaper city by the single-newspaper city" (Kesterton, 1967: 97).

In 1900, there were 17 two-newspaper cities in Canada. By 1966, that number had shrunk to nine, and there were 75 cities with only one daily. In 1913 , the Canadian newspaper industry reached its peak in terms of the number of dailies, with 138 , and the move toward concentration of ownership was well under way (ibid.: 78), as publishers began to expand their holdings. "Until World War I the drive toward monopoly at first concentrated on price cutting and combinations to restrain competition. During the war, the purchase and amalgamation of competitors became the preferred strategy" (Sotiron, 1987: 6). By 1980, 74 percent of English-Canadian newspapers, and 90 percent of newspapers in Quebec, were in the hands of chains (Kent, 1981: 2-3).

At the same time, the audience for newspapers was shrinking, under attack by new competing media, a recurring refrain in 20 th and 21 st centuries that began in the 1930 s, with the growth of radio news. Even in the face of the Great Depression, radio exploded across Canada and the United States, creating the second North American national medium, after consumer magazines. For example, in the United States, by 1935 , there were 30 million radio sets in homes, and more than 600 stations broadcasting (ibid.: 171). 
In Canada, there was a growing fear that the national conversation was being dominated by foreign voices, in the form of radio signals crossing the border. This led to the Broadcasting Act of 1932, which brought about the creation of the Canadian Broadcasting Corporation/Radio-Canada in 1936. Though many Canadian newspapers owned and operated private radio stations-such as CJGC, by the London Free Press, and the Toronto Star's CFCA - many "newspaper proprietors grew almost irrational in their fear of radio," a dread that was transferred to television in the 1950s (Fetherling, 1990: 110). As well, radio presented the first opportunity for politicians to appeal directly to a mass audience, without having to subject themselves to mediation. The most famous example of this was U.S. President Franklin D. Roosevelt's famous Fireside Chats of the 1930s. The way politicians today use YouTube, Facebook and Twitter, Roosevelt turned to radio to bypass what he saw as a biased media and to "restore direct contact between the masses and their chosen leaders" (Cited in Teel, 2006: 167).

Interestingly, however, there was evidence that broadcast news actually helped newspaper circulation - if the newspapers delivered the right content. One of the first big TV news events was U.S. Gen. Douglas MacArthur's return to the United States from Korea in 1951, after his firing by President Harry S Truman. TV cameras followed MacArthur from the moment he arrived home to when he gave his famous "Old soldiers never die" speech to Congress. However, one survey showed that, rather than undermining circulation, the coverage drove Americans to their daily papers. "Televised news events seemed to increase readers' curiosity about these events, pushing them to buy the newspaper to read about what they had just seen" 
(Davies, 2006: 52). This implied that people wanted more than the unvarnished facts. Television was whetting the public appetite for nuance, detail and interpretation. The “increasing 'threat' of broadcast news, coupled with inescapable societal conflict, helped propel newspapers into new ways of reporting and presenting news-and prompted what might have been the best and most varied journalism in American history" (McPherson, 2006: 1).

YET, OVERALL, circulation began to slide with the introduction of TV, and continued through the century and into the next. For example, in the mid-1950s, Canadian newspaper companies were selling one copy for every household in the country; by the late 1990 s, the figure had dropped to just over 50 percent. In a late1990s poll, 34 percent of respondents said newspapers were very important to them, down from 45 percent 10 years earlier (Miller, 1998: 11).

While circulation was shrinking, newspapers in Canada and the United States were growing in physical size - driven by increasing demand for advertising. In 1945 , a typical mid-size U.S. daily averaged a 22-page edition on weekdays. By 1962 , this had grown to 50 pages and, though most of that growth was given over to advertising content, the editorial news hole had increased from 12.3 to 19.7 pages (Davies, 2006: 112).

The high-water point for daily newspapers in the United States was 1945, with 1,749 dailies selling 48.4 million copies a day, and $\$ 216$ billion in ad space over the year (ibid:: 3-4). That year also was the point at which people began to turn away from newspapers. To some extent, readers were being drawn away by electronic 
media, particularly television, which quickly and painlessly delivered the headlines that were all many people read anyway. At the same time, as Newsweek magazine put it, radio "stalked the nation like a zombie, long dead but somehow still alive" (ibid: 112.). Forced out of the network entertainment game by television, radio had remade itself as a portable medium for teenagers who wanted to take their music to the beach, and for adults who wanted news on the move, in their car radios. Also, with the disappearance of the national commercial radio networks, the medium concentrated more on local news and discussion, further fragmenting the newspapers' target audience.

Still, the number of U.S. papers remained relatively stable, and circulation continued to climb, reaching its all-time high of 58.9 million in 1960 , a healthy increase of some 21 percent since 1945 . However, the population of the United States had grown from 139.9 million in 1945 to 180.7 million in 1960 , an increase of 29 percent. (U.S, Census Bureau, 1999: 868). So, over those years, readership had actually shrunk by eight percent relative to population.

Still, it wasn't until the late 1970s that newspaper owners and publishers began to respond to the fact that their circulations were flatlining or declining. In Canada and the United States, circulation continued to shrink in relation to the growth of population. In 1970,63 million American households bought 62 million newspapers daily; in 2002, 56 million papers were purchased by 106 million households (Teel, 2006: 115-116). There had been several closures of prominent, mostly afternoon, dailies, such as the Montreal Star (1979), the Ottawa Journal and the Winnipeg Tribune (1980) in Canada, and the Philadelphia Bulletin and 
Washington Star (1981) in the United States. Yet, in the 1980s, newspapers in both countries recorded record profits; the survivors in one-newspaper towns were reaping the harvest of mass advertising.

A drastic drop in household sales of newspapers during a period of record newspaper profits seems paradoxical, but it is a paradox with a number of causes. Disappearance of competitive newspapers always causes losses of sales. When dailies merge, the surviving paper never keeps all the readers from both papers; some readers are interested only in the paper that has disappeared and other readers who used to buy two or more papers a day when they were available can buy only one when there is a monopoly (Bagdikian, 1992: 196).

In Canada, this weeding out was also accelerating a process that would lead in the 1990s to extraordinary levels of concentration of ownership. There are two main factors that contributed to this: geography and law. The main population centres of the country are spread across some 6,500 kilometers along the U.S. frontier. So, in most parts of the country, it's uneconomical to "cluster" newspapers into regional chains, as many are in the U.S. Similarly, because of the distances involved, national newspapers, such as the London dailies that had come to dominate the market in the United Kingdom, were impossible to distribute in North America until the early 1980 s, when satellite technology allowed such papers as the Globe and Mail, the New York Times and the Wall Street Journal to create national editions, and for the Gannett Co. to launch USA Today. The second factor is a rule put in place in 1965 by Parliament that effectively bars nonCanadians from owning Canadian newspapers. Under the Income Tax Act, any company that advertises in a publication held by a private company that is more than 49 percent foreign owned, or a public one more than 25 percent foreign owned, is not permitted to claim advertising expenses as a tax deduction. This means a foreign-owned newspaper would operate with a debilitating handicap in selling advertising in the Canadian marketplace, and it is unlikely any large foreign newspaper company would be attracted 
to investing in an enterprise it couldn't control.

In the United States, as in Canada, the trend towards concentration of ownership began in the first decade of the 20 th century. One model of chain ownership was established by Edward Willis Scripps, whose business strategy was to establish "cheap new dailies for underserved audiences, especially urban workingmen" (Teel, 2006: 5). The other, more enduring, style of expansion was established by Frank Munsey, the "gravedigger," who made a fortune of $\$ 40$ million by purchasing newspapers and finding ways to squeeze greater profits from them, and then used those profits to finance further expansion (ibid.: 29). Chains that followed this style of acquisition and management include the Hearst, Copley and Gannett companies in the United States and Thomson, Southam, FP, Hollinger and Quebecor in Canada.

As the first chains began to gobble up independents, media critics sounded the first alarms. As early as 1928 , the editor of The Nation wrote that chain ownership was causing a decline in the quality and originality of U.S. newspapers. The symptoms of chain dominance were: "a lack of individuality; growing conformism dictated by media magnates; increasing preoccupation with entertainment, comics, and feature stories; and growing influence of advertising departments over editorial and news decisions" (Teel, 2006: 111). Defenders of the industry responded with the argument that the commodification of news, and economies of scale made consolidation of ownership inevitable. As we'll see in Chapter 3, this chorus and counter-chorus remained a salient feature of the discourse about journalism through the 20 th century. 
In the United States, between 1945 and '65, the number of daily papers owned by chains almost doubled, from 365 to 750 (Davies, 2006: 118). The main force driving consolidation was tax law. On one hand, publishers could avoid paying tax on earnings that were reinvested-and buying other newspapers was a way to increase earnings and reduce tax at the same time. On the other hand, inheritance and incomes taxes encouraged heirs to sell family-owned papers they inherited (ibid.: 119). In the early 1980s, there were 50 large U.S. media companies "that dominated American audiences," and 20 dominant newspaper chains. "By 2003, five men controlled all these media once run by the fifty corporations of twenty years earlier" (Bagdikian, 2004: 27).

Critics of chain ownership continued to complain that this was fostering monotony and blandness, a sense that every paper in every city was being stamped out on the same assembly line.

A single owner concentrates energies, skills and managerial and journalistic resources on one newspaper and has the power (and often the economic motivation) to reinvest surplus profits in the long-term strength of that paper and its relationship to that one community. A chain owner does the opposite. With rare exceptions, reinvestment in the long-term health of individual daily papers is a low priority compared to the inexorable demand of its parent firm for maximum profits, often for expansion elsewhere (Bagdikian, 1992: 226).

IN CANADA by the early 1980s, the increasing concentration of ownership had caused enough concern that the federal government created a Royal Commission on Newspapers, chaired by Tom Kent, to investigate. The Kent Commission inquiry was the result of a massive shudder in the business that had been decades in the making. In the 1960s and '70s, the largest newspaper company in Canada, in terms of 
circulation, was FP Publications, which owned such major city dailies as the Winnipeg Free Press, the Vancouver Sun, the Toronto Globe and Mail, the Ottawa Journal and the Montreal Star. In second place was the Southam chain, with such holdings as the Edmonton Journal, the Calgary Herald, the Hamilton Spectator, the Ottawa Citizen and The Gazette in Montreal. In terms of number of dailies owned, the largest chain was Thomson, which began the 1970s with 41 daily newspapers and ended it with 38 (Hallman and Oliphant, 1981: 43). These were exclusively smalltown newspapers with limited circulation, but they were very profitable.

In 1980, FP foundered after expensive strikes in Vancouver, Victoria and Montreal. In Montreal in 1979, the Star fell victim to changes that were sweeping the industry. Afternoon papers had been struggling through the decade and by the early 1980s, were on the verge of extinction across the continent-victims of late-afternoon traffic congestion that delayed delivery and forced earlier and earlier deadlines, making it almost impossible for papers to compete with the evening television news, which had created a new news-consuming habit in the population. In February 1980, less than six months after the Star's demise, FP was bought by Thomson, which almost immediately launched the national edition of the Globe and Mail. Then, on one day in August 1980, Thomson closed its newly acquired FP paper, the Ottawa Journal, and Southam closed its Winnipeg Tribune. This left Thomson with a monopoly in Winnipeg and Southam with one in Ottawa. At the same time, Thomson sold its share of the Vancouver Sun and Montreal Gazette to Southam, giving that chain two additional monopolies, and merged its Victoria dailies into a single paper.

This meant that Thomson and Southam controlled more than threequarters of the total Canadian circulation, and head-to-head 
competition between dailies had disappeared from every city except Toronto and St. John's, Newfoundland. It amounted to a wholesale restructuring of the $\$ 2.5$ billion Canadian newspaper industry (Hayes, 1992: 163).

Thomson and Southam remained the dominant chains until the mid-1990s, when the former began to reorganize itself and discard newspapers, and the latter was acquired by Conrad Black's Hollinger Group. At the time, Black said he foresaw “one more mighty cycle of newspaper profits left, at least” (Miller 1999: 90). In 1995, Black's main newspaper holdings were the Telegraph group in England, the Chicago Sun-Times and the Jerusalem Post. In Canada, he was proprietor of Sterling Newspapers, which ran tiny dailies, mostly in British Columbia, and UniMedia, owner of Quebec City's journal of record, Le Soleil, and the tabloid Le Droit in Ottawa. Within 18 months, Black had acquired 40 papers by swallowing up Southam, most of Thomson's Canadian holdings, and the Armadale group in Saskatchewan. He also founded the National Post, to compete with the Canada-wide Globe and Mail. No one else in Canada was interested in buying daily newspapers, or had the resources to acquire them, and the Income Tax Act kept the big U.S. companies from moving north. So, the number of players had been fixed by circumstance. While many papers were coming up for sale, only one person was in a position to buy them.

The 1990 s closed with an attempted hostile takeover of the Sun chain by Torstar, which failed when Quebecor stepped in with a higher per-share bid. That completed a total realignment of the newspaper business. Two corporationsHollinger Inc. and Quebecor-controlled 66.1 per cent of Canada's newspaper circulation, and two more - Torstar and Thomson - held another 21.3 percent. The total owned by the four companies: 87.4 percent (Wilson-Smith, 1998). 
In 2000-01, the Canadian media companies reorganized themselves yet again. Canwest took over most of Hollinger's Canadian holdings-including 13 major Canadian dailies and the National Post-merging them with its Global Television Network as content providers for print, TV and the Canada.com website. In 2002, they sold off many of the smaller properties, such as the St. Catharines Standard and the Kingston Whig-Standard, to the newly formed Osprey Media. BCE Corp.-which already controlled Bell Telephone, the Sympatico-Lycos Web portal and the satellite TV company Bell-Express Vu-took control of the CTV network and its group of broadcast and cable channels, and formed an alliance with Thomson to jointly operate the Globe and Mail, giving it television and print content providers for the Internet, as well as the means with which to bring the content into homes. Finally, Quebecor won a bidding war with Rogers Cable for control of the Quebec cable provider, Groupe Vidéotron - which included the TVA television network. And that, aside from some minor manoeuvrings, was how things stood until the recession of 2008 , which, as we will see in Chapter 4, destroyed one large media company, realigned the Canadian television landscape, and saw Quebecor acquire Osprey.

THE STAGE had been set for these upheavals by a long, deep recession in the early 1990 s, which sent an industry that had grown accustomed to record profits into shock. In Canada and the United States, the newspaper business was increasingly dominated by publicly owned companies, whose shareholders had grown used to return on investment of 20 to 40 percent of revenue (Fink, 1996: 17). In the United States, the gold standard for this was the Gannett Company, which at least until the mid-1990s, 
demanded 30 to 50 per cent profit margin from its publishers (Underwood, 1995: 98) and went 18 years, from 1967 to 1985 , with each quarterly profit greater than the one before it (Bagdikian, 2004: 184). Another major acquirer of media properties was the Chicago Tribune Co., which, over the course of the decade, bought up a host of TV stations and newspapers - including the Los Angeles Times. The company ran up a debt of $\$ 13$ billion, which, as we will see in Chapter 4 , was to make it one of the most spectacular casualties of the recession of 2008 .

On an international level, the great acquisitive force was Rupert Murdoch who, over three decades acquired and discarded major papers in the United States and Britain, ranging from the News of the World, Sun and Times in the U.K. to the Chicago Sun-Times and the New York Post, and founded TV networks on both sides of the Atlantic, most notably Fox and Fox News in the United States.

Even as all this acquisition activity - propelled by ever increasing corporate debt loads - was going on, display advertising had been dropping off. A 1994 survey done for Canadian publishers by consultant Len Kubas revealed that of the six factors that determine newspaper success, four were in decline: circulation, readership, advertising lineage and public image (Miller, 1998: 11). Between 1990 and 1995, Canadian industry advertising revenues dropped 27 percent, from $\$ 2.2$ billion to $\$ 1.6$ billion, and then plunged another five percent in 1996 (ibid:: 13). This was partly fueled by a foundering retail industry, partly by advertisers focusing on demographic data to target preferred customers, and partly by the combination of high newspaper ad rates and the dwindling audience. 
Yet, even with the recession of the early 1990s, newspaper profits remained high compared to other industries, 12 to 15 percent for many, and still in the 25 to 30 percent range for some-compared to General Motors' 4.3 to 4.4 percent and Exxon's 5.8 to 9.4 percent (Fink, 1996: 17). By the late 1990s, advertising linage and revenue had rebounded, but Canadian dailies were earning only slightly more from ad sales than they had been before the recession.

Some of the new business comes from advertising inserts, a credit not to any renewed faith in newspapers but rather to a vigorous lobbying campaign by the newspaper industry that persuaded the federal government to get Canada Post out of the lucrative door-to-door delivery of flyers. A list of advertisers who by and large ignore newspapers today includes such household names as Procter and Gamble, McDonald's, Seagram's, Ford Motor Company, Coca-Cola, Nissan, Kodak and Campbell's Soup. They are saying something scary to publishers: "You're not worth our money" (Miller, 1998: 11).

The situation was more or less the same in the United States. Carl Sessions

Stepp, senior editor of American Journalism Review, summed it up this way:

Today's editors live ... in an oddly paradoxical age. Newspaper profits are rocketing, but circulation - and confidence - continue to slip. In the most pessimistic circles, something approaching a deathwatch is on, and even the optimists can be caught looking over their shoulders, or, worse, gazing at the backsides of competitors that already seem to have surged past them. In a sober-up-or-else comment at this year's American Society of Newspaper Editors convention, Intel Chairman Andrew Grove warned that newspapers could be three years away from meltdown. "Nothing sharpens the awareness of a situation like the sight of the gallows," he said (1999).

In Canada, Globe and Mail publisher Phillip Crawley pointed out that, although newspaper readership was growing in the developing world, circulation was "down in the U.S. by five percent, the European Union by four percent and in Canada by 10 percent." 
[T The newspaper business in the developed world is a mature business-one with lots of new competition such as the Internet, 24hour TV news and all-news radio ... (O)nce popular afternoon dailies, traditionally read by blue-collar workers, continue to close as the proportion of white-collar workers rises. (S)ince the recession of the early 1990s, many papers have reduced some forms of circulation not required by advertisers" (1998).

AS THIS postwar decline was taking place on the business side, there were important changes happening in the newsroom. In tandem with the rise of the commercial newspaper industry, objectivity had been emerging as the core belief of modern journalism. As well, as Schudson points out, there was a major change in journalists' attitudes toward their work - from a trade to a profession.

The ideal of objectivity in the news is little more than a century old, and when journalism became modern, professional and respectable, the press turned its back on the literary and muckraking traditions of the penny press, and adopted a quasiscientific approach to news-gathering that was designed to bolster its new view of itself. Beginning in the mid-19th century, reporters "began to see themselves, in part, as scientists uncovering the economic and political facts of industrial life more boldly, more clearly and more 'realistically' than anyone had done before" (Schudson, 1978: 71). This could be seen as a triumph of Lippmann's vision of public communication as something that should be governed by professionalism and conducted in a methodical, cold, scientific way.

This was an attitude born of the 19th century, a time of great faith in science to tame nature and impose logic upon the world. In the sense that he had great faith in both scientific process and professionalism, Lippmann was very much a child of the 
19 th century and a shaper of the 20 th. Two of the most important words in the Victorian vocabulary were "authority" and "progress," (Briggs \& Burke, 2007: 96), and this was a time when all fields were finding it necessary to establish, or certify, their credentials and exclusivity. In the 1870 s and 1880s, there were at least 200 "learned societies" founded in the United States, ranging from the American Chemical Society to the Geological Society of America, to the national Statistical Association (Bledstein, 1976: 86). "[I]n the mind of mid-Victorians, professionalism ... embodied a more radical idea of democracy than even Jackson had dared to dream ... a liberated person seeking to free the power of nature within every worldly sphere, a self-governing individual exercising his trained judgment in an open society" (ibid.: 87).

Alterman points out that the growth of professionalism and objectivity can be seen as "the fulfillment of a kind of circular journey for American journalism" (1992: 22). Before the penny press, there had been no division between fact and opinion: the newspaper owner-editor-publisher was a pamphleteer, journalist, pundit and occasionally politician as well. With the invention of the penny press and of the reporter, news and opinion had been severed from each other. If there was an opening shot fired in the battle against the subjective narrative, it came in 1851, with Henry J. Raymond's front-page launching message for the first edition of The New York Times, announcing a separation between "news and views" (Briggs \& Burke 2005, 155): "We do not mean to write as if we were in a passion unless that should really be the case; and we shall make a point to get into a passion as rarely as possible" (Alterman, 1992: 26). Raymond was reacting to the excesses of his former employer, 
Horace Greeley's New York Tribune, which had invented the editorial page, but had not purged its news pages of opinion (ibid.: 25). Compare Raymond's remarks to the inspirational mission statement laid down in 1835 by James Gordon Bennett for his New York Herald, and you get a glimpse of the recurring struggle between Lippmannian realism and Deweyan idealism: "My ambition is to make the newspaper press the great organ and pivot of government, society, commerce, finance, religion, and all human civilization" (Briggs \& Burke, 2005: 155). Bennett also believed that a newspaper could "send more souls to heaven and save more from hell than all the clubs and chapels in New York" (ibid.). In spirit at least, he has much in common with Dewey and the public journalism.

It was The New York Times that set the standard for the modern newspaperand by extension the all-news TV network - in that it was not so much dedicated to objectivity as to the appearance of objectivity (Alterman, 1992: 27). That appearance of objectivity, as many observers have noted, became "the emblem of American journalism ... an improvement over a past of 'sensationalism' and a contrast to party papers of Europe" (Schudson 1978: 9).

It's interesting, then, that along with separating news from views, the penny press helped usher in an age of public opinion. The 19th century British statesman Richard Cobden argues that "the influence of public opinion as exercised through the press" is the "distinguishing feature of modern civilization" (Briggs \& Burke, 2005: 157). And this at a time when the ideal of public service journalism was giving way to "the realities of the market" (ibid.: 159). 
IT WAS also in the mid-20th century that journalists began to aspire to a

Lippmannian sort of refinement. "Pre-Lippmann ... [r]eporting was seen as a job for winos, perverts, and those without sufficient imagination to become successful gangsters" (Alterman, 1992: 22). But, thanks to journalism schools in universities and a growing corps of university-educated reporters and pundits emulating public intellectuals like Lippmann, journalism had become a profession for serious-minded university graduates (Schudson, 2003). Time magazine's description of the sudden transformation of The Toronto Star in 1957 could be taken as a model for the process.

The Toronto Star turned grey one day last week. Banished overnight were the sensation and sudden death once trumpeted in blazing, twoinch headlines. Staffers were forbidden to mention the nude bodies and sanguinary scenes that once covered Page One; crime reporters could no longer identify criminal suspects until they had been formally charged ... young [publisher] Joe [Atkinson] ordered drastic cutbacks, told editors to drop far-flung junkets (Quoted in Harkness, 1963: 383).

In 1961, new Star publisher Beland Honderich put a finer point on it, when he told a group of editors, "The basic function of a newspaper is to inform, to tell the public what is happening in the community, in the nation and in the world. You will notice I did not use the word 'entertain' " (Gerard: 2005).

As a Houston Post executive put it in 1950, journalism was shifting its emphasis "from scoop to scope" (Davies, 2006: 29). In the post-Second World War world, the North American popular newspaper found that its readers were demanding information and analysis that could help them make sense out of international tensions, galloping scientific innovations and a booming economy. So the "old triedand-true formulas for news"-crime, sex and money and politics-were being "crowded by labor, industrial and science news ..." (ibid.: 16). 
So, as the creed of objectivity pushed opinion and interpretation from news writing, the op-ed pages grew fatter and more powerful. "Absent a professionally sacred faith in objective news gathering, there would be no call for political pundits to comment on it" (Alterman, 1992: 28). To put it another way, "Objectivity is an ideology of distrust in the self" (Schudson, 1978: 71). In this atmosphere, journalism abandoned the subjectivity and nuance of literary journalism and the passionate moral imperative of muckraking and replaced them with objectivity. Objectivity provided a new model of journalism for the era of the man in the grey-flannel suit. "The rakish self-image of the urban journalist gave way to a buttoned-down image of the White House correspondent, one who might even give occasional political counsel to an aspiring senator or presidential candidate" (Schudson, 2003: 86-87).

Lippmann was a classic example of this kind of insider/observer. He wielded enormous influence in Washington up to the last decade of his life. An example of his influence is the fact that, as Schlesinger points out, the New Yorker once suggested that, if the U.S. monarchist party were to succeed, Americans would be glad to settle for Walter Lippmann as king (1959: 189). One measure of his reach and influence is that, in 1935 , just four years after he began his nationally syndicated "Today and Tomorrow" column, the New Yorker ran a James Thurber cartoon depicting a woman turning to her husband and saying, "Lippmann scares me today" (1974. Orig. 1935). Over the course of his career, Lippmann won two Pulitzer prizes, a Presidential Medal of Freedom and three Overseas Press Club awards for "interpretation of foreign news" (Whitman, 1974). He was the author of 21 books and the subject of a dozen. When he died, the New York Times declared him "the dean of American 
political journalism in the 20th century" and "a public political thinker of towering eminence whose wisdom was pondered by men in high station and low the world over" (ibid.).

Lippmann believed journalism should aim to be a collaboration of sober factgatherers and thunderbolt-hurling pundits-like Walter Lippmann. Alterman argues that he was the prototype for every newspaper opinion page pundit who came after. Tom Wolfe, who worked in Lippmann's home newsroom, The New York HeraldTribune, calls him "the archetypal newspaper columnist."

For 35 years, Lippmann seemed to do nothing more than ingest the Times every morning, turn it over in his ponderous cud for a few days, and then methodically egest it in the form of a drop of mush on the foreheads of several hundred thousand readers of other newspapers in the days thereafter. The only form of reporting I ever remember Lippmann going for was the occasional red-carpet visit to a head of state, during which he had the opportunity of sitting on braided chairs in wainscotted offices and swallowing the exalted one's official lies in person instead of reading them in The Times (1973: 12).

WHILE LIPPMANN and his descendants were ruling the op-ed pages, Wolfe writes, reporters, who saw themselves as storytellers, were chafing against the "pallid little troll" (ibid.: 17) of understatement and objectivity, who ruled the postwar newsroom. And reporters weren't the only ones who had a problem with objectivity. For example, in a speech at Carleton University in 1989, Toronto Star publisher Beland Honderich stirred up controversy by coming right out and admitting that he thought objectivity was not a desirable characteristic of a newspaper.

No self-respecting newspaper deliberately distorts or slants the news to make it conform to its own point of view. But you cannot publish a newspaper without making value judgments on what news you select 
to publish and how you present it in the paper. And these value judgments reflect a view of society - a point of view if you will-that carries as much weight, if not more, than what is said on the editorial page (Gerard, 2005).

This brings us to the likes of Dewey, Carey and Adam, and their exhortations that communication is culture and journalists should behave as if they are artists. The way Dewey puts it is that a "responsive art of communication must take possession of the physical machinery and circulation and breathe life into it" (1954: 183). Adam's answer to the question of how is that journalists should rediscover their imagination. He means that in two senses. The first and more obvious one is the individual's ability to conceive, explore, understand and form thoughts out of things and experiences (Adam, 2006: 364). The second is in the sense of the Journalistic Imagination: "the primary method of framing experience and forming the public consciousness of the here and now" (ibid.: 365). This is patterned after C. Wright Mills's Sociological Imagination, something that allows the observer to look at the grand picture and not just coldly observe phenomena, but to extrapolate the variety of its meanings and possible effects on the people who may be affected by it. This, Mills wrote, involves a blending of life experience, intellectualism and emotional understanding that creates a sense of craftsmanship, of someone "at work on problems of substance" (ibid.: 195).

In journalism, this involves "the imposition of the narrative line upon disparate images, by the 'idea' with which we have learned to freeze the shifting phantasmagoria which is our actual experience" (Didion, 2006b: 185). Like literature and cinema, Didion writes, journalism can provide a narrative line for us to use to 
interpret the world in which we live. "We look for the sermon in the suicide, for the social or moral lesson in the murder of five" (ibid.). In a similar vein, Schudson defines the news as a product manufactured with the intent of involving the public in a discourse about subjects that are "publicly important." He quotes media scholar John Hartley: that news is "sense-making practice of modernity ... the most important textual system in the world." The news ...

builds expectations of a common, shared world; promotes an emphasis on and a positive valuation of the new; endorses a historical mentality ... and encourages a progressive rather than a cyclical or recursive sense of time. The novel, as literary scholar Ian Watt pointed out, has a very similar resonance, and it is significant that it emerged as a prominent element in the cultural landscape of Europe and colonial North America at the same time the newspaper did - in the eighteenth century (2003: 1-12).

Too often, Adam argues, social scientists, journalism educators and some journalists impose a bland, bureaucratized professionalism on journalism, and refuse to see it as an art form or even popular culture.

Professional practitioners are inclined to define journalism in terms of limited newsroom conceptions and thus jettison any consideration of journalism's poetics or its ambitious forms; sociologists, communicologists, and political scientists are inclined to read journalism functionally rather than intrinsically and thus contribute to the leveling impulse that originates with the practitioners. Neither the practitioners nor the social scientists are sufficiently inclined to lift journalism out of the bureaucratic settings in which journalists are likely to operate and imagine journalism as the best journalists do as they make news judgments, engage in reporting, and compose accounts of the world (2006: 345$)$.

Similarly, Elihu Katz and David Foulkes argue that studying the media "as agents of entertainment," rather than as "agents of persuasion" opens up a "bridge to the theorists of popular culture" and reorients the study from one of what the media is 
doing to people to "what do people do with the media" (2009: 378-379). The concept of news as popular culture may deflate some of the more-self-important views of the news media-journalists as guardians of democracy or teachers-but, again as Katz and Foulkes point out, communication scholars of the radio age saw newspapers as providing "ritualistic activity, orientation to everyday living (and dying), conversation starters and the like" (ibid.: 378). Thus, news culture "becomes the central storehouse for the various national conversations" of the culture (Schudson, 1995: 179).

BRIEFLY, THERE was a movement in the United States that tried to take possession of the machinery and retool it to manufacture popular art based on the literary and muckraking traditions of the penny press. In the 1960 s and ' 70 s, a generation of reporters began to question the creed of objectivity and the trustworthiness of power. Schudson (1978) argues that this grew out of what literary critic Lionel Trilling called the "adversary culture" of modern writing, in which the hero stands at a remove from society, offering a vantage point from which to critique and revise it. Most young journalists, like young people in the society at large, were better educated and more inclined to set themselves up in an adversarial position to a society they had come to distrust. Having grown up on often iconoclastic post-Second World War cinema and literature that was largely concerned with social justice, and having witnessed the empowerment of the working classes in North America and England, these journalists were often contemptuous of "straight" society, and rebellious toward a newsroom culture they saw as grey and unquestioning of authority (ibid.: 176-177).

There were important mainstream pockets of this New Journalism - notably in 
such magazines as Esquire, the Saturday Evening Post and the Herald-Tribune's Sunday magazine, New York ${ }^{2}$. However, this new style of journalism was mainly rising from the underground press - from periodicals such as the Village Voice ${ }^{3}$, the Boston Phoenix, the Los Angeles Free Press, Rolling Stone, Ramparts and New Times.

Similar to the way the Internet is putting the levers of power into the hands of the peasantry today, technological innovation had made it possible for a new generation to create publications that focused on cultural and political subjects that the mainstream press refused to take seriously. Offset printing, photo-engraving and cold type made publishing, easy, fast and cheap. No longer did a publisher need presses, engravers and hot-lead typesetting equipment on premises. Words, pictures and layouts could be delivered to one end of a printing house and a pile of newspapers picked up at the other. The result was a rash of feisty, stylish and often downright weird writing, typography and layout, and a sense of literary and graphic experimentation that influenced a generation of writers, photographers, designers and editors. The Seattle Post-Intelligencer described the field as ranging "all the way from little sheets explaining how to make a Molotov cocktail to large publications that are so serious they are Dullsville" (Cited in McPherson, 2006: 25). This description of New York's East Village Other could be applied to the entire underground press of the 1960s and early '70s: "The Other doesn't separate fact from opinion. Its journalism is unabashedly, militantly, interpretive: pro pot, peace, sex,

\footnotetext{
${ }^{2}$ Which was spun off as a glossy weekly in 1968, a year after the Herald-Tribune folded. It remained an important forum for New Journalism through the 1970s.

${ }^{3}$ Co-founded in 1955 by Norman Mailer, who, through such works as Miami and the Siege of Chicago and The Armies of the Night became one of the most influential New Journalists of the late 1960s.
} 
psychedelics and subversion; anti most of what remains in switched-off American society" (ibid.). Although the one thing these journalists had in common was contempt for the straight media, their call for a more investigative and interpretive style of journalism resonated with many older colleagues, who saw change as a way to deal with the competition of TV news, the "unblinking eye" that was cornering the market on apparent objectivity (Schudson, 1978:181).

The way Wolfe puts it is that, in the mid-60s, there was an awakening of the "lower class" of letters: the "day laborers who dug up slags of raw information for writers of higher 'sensibility' to make better use of" (1973: 25). The revolution came from the lowest social order, the freelancers who wrote for Sunday supplements, slick magazines, and the alternative press.

[A] bunch of these lumpenproles ... with no literary credentials whatsoever in most cases ... they're using all the techniques of the novelist ... and on top of that, they're helping themselves to the insights of the men of letters while they're at it ... and at the same time, they're doing their low-life legwork, their 'digging,' their hustling, their damnable Locker Room Genre reporting ... (ibid.)

Meanwhile, two events in the 1970s placed journalism at odds with a power establishment with which it had formerly identified: the publication by the New York Times and Washington Post of The "Pentagon Papers" in 1971, and the Post's investigation of the Watergate break-in by the Committee to Re-elect the President and subsequent coverup by the Nixon Administration in 1972-73. This changed journalism, in that news organizations "that had once cooperated routinely with government began to see 'national security' as a euphemism for 'stay out of my business because I could be embarrassed by publicity' ..." (Schudson, 2003: 88). As the Internet often does today, the alternative press was, to a certain extent, setting the 
agenda for the mainstream media - in some cases leading the way with investigative work that forced the mainstream dailies to respond by being more aggressive in their work. However, investigative journalism gave the newspapers an alternative to the New Journalism, "a format more palatable to mainstream journalists concerned with objectivity," because the journalist was able to stand apart from the story (McPherson, 2006: 50).

Neither New Journalism nor investigative reporting lasted, except in book form and at some magazines. And the underground press gave way to the alternative newspaper, a self-consciously hip inner-city giveaway that was little more than an excuse to carry display advertising, event listings and racy classifieds. The New Journalism was a little too hard to control for most newspaper editors, investigative journalism was legally risky and expensive to produce, and "adversary journalism passed out of favor almost as soon as editors began to worry about giving readers what they want, and they surely didn't want more bad news" (Miller, 1998: 231). For the mainstream press, the answer was a return to objectivity.

To be fair, owners, publishers and editors had compelling reasons to back away from the concept of journalism as art. There is some reasonable cause for concern about how the idea of journalism as an art, or at least a craft, can be misinterpreted - and there's no question that artists are harder to find, and require a great deal more policing and grooming, than fact-gatherers. In an article revisiting Tom Wolfe's New Journalism classic The Electric Kool-Aid Acid Test, Jack Shafer praises writers such as Wolfe, Didion, Norman Mailer, George Plimpton, Terry Southern and Gay Talese for "restoring strong narrative, detailed reporting, and point 
of view to American feature journalism" (2006). He also laments the fact that so much attention was paid to style and technique that many people forgot that the foundation of all New Journalism narrative was extraordinarily intensive reporting. One unfortunate by-product of the movement was "two generations of boneheads who thought the lesson of the New Journalism was to pound on the exclamation key while writing yourself into the story" (ibid.). Even Hunter Thompson-whose gonzo journalism was probably responsible for giving birth to more of those boneheads than any other form of the genre - had this to say about Wolfe: "The only thing new and unusual about Wolfe's journalism is that he's an abnormally good reporter; he has a fine sense of echo and at least a peripheral understanding of what John Keats was talking about when he said that thing about Truth \& Beauty" (Weingarten, 2005:124).

This type of fact-intensive literary journalism still exists in the pages of such high-end general interest magazines as Atlantic, Harpers, The New Yorker and, in Canada, The Walrus - and online at such sites as Slate and Vancouver's The Tyee. A magnificent example is the three-part series "American Ground," which William Langewiesche wrote in 2002 for Atlantic about the terrorist attacks of Sept. 11, 2001. Fanatical in detail and vivid in presentation, the series answered the main question all the punditry and sober just-the-facts reporting, and even all the pictures and film had failed to. Langewiesche told his readers what it was like: what it was like to be inside the buildings when the planes struck; what it was like to be a fireman rushing against the tide into the doomed towers; what it was like to dig down through the rubble and enter the subterranean city of abandoned shops and flooded subway and PATH train tracks. Langewiesche proves Shafer's argument that "narrative is the finest container 
ever devised to transport ideas, especially transporting ideas over time" (2006), not to mention Thompson's observation that the main thing that distinguishes excellence from mediocrity in journalistic writing is "abnormally good" reporting.

MEANWHILE, that handmaid of old-school politics, the straight, or mainstream, media has been, as Bagdikian puts it, repeatedly pronounced dead over the years of the rise of the Internet (2004: 114)-as it had been by the underground press of the 1960s. To a certain extent, this looks a lot like a self-fulfilling prophecy.

Many media companies are only grudgingly holding onto their paper assets while profit margins shrink, but remain at levels of which many other industriesparticularly manufacturing-can only dream. A Statistics Canada report showed that "[t]he operating profit margin for Canadian newspaper publishers declined for the second straight year in 2005, as growth in operating expenses outpaced revenues. Yet, “the industry's operating profit margin in 2005 was 13.3 per cent, compared with 14.2 per cent in 2004 and 15.1 per cent in 2003" (Canadian Press, 2005). Nevertheless, the daily newspaper is, more or less, seen as a drain by most large media companies, some of whom, as we'll see in Chapter 4, have begun to "harvest" their old-media properties and focus on the new, even though the new media provides a fraction of the profits the old did. Bagdikian argues that this is mainly because news has no reusable value. A media company that owns a novel, can repurpose it as a film, a video game and a television show. "An original news item is dead the day it is printed, while a popular sitcom or detective series can have an impressive life span" (Bagdikian, 2004: 115). Yet, for reasons no one has ever been able to adequately 
outline, in the 1990s, news companies with very few exception made the decision to give away the news for free. And, if they charged for content at all, it was for the worthless archival material, which, for the few researchers who cared, was available to copy at any public library

Newspaper companies have been working on figuring out the Internet since before there was an Internet. "For a century, publishers have dreamed of electronic transmission of the paper into each home, thereby ending presses and hand delivery" (ibid., 118). As early as the mid-1980s, theorists were talking about the day readers would subscribe to a "paperless newspaper." No one was quite sure what this would look like, but nearly everyone was sure it was coming - which should not have been much of a stretch for an industry that had been receiving news electronically from the wire services since the early 1970s. Experiments with "videotext" and "audiotext" in the 1980s and early ' 90 s proved expensive and, in the case of the latter, pointless and stupid. In retrospect, it's not surprising that readers were uninterested in paying good money to endure the frustrating experience of being guided by robot voices through menus that would lead them to someone reading their daily horoscope or to a tinny, unintelligible version of a pop song.

Until recently, the news media appeared to be trying to replicate themselves online in the exact image of their real-world selves. The dominant forms of Internet news delivery remain the newspaper and television Web site. Yet the industry can't find a way to wring the kind of profits from the Internet that print delivers. As we shall see in Chapter 4, Internet advertising revenue delivers nothing like the profits print does. As well, by choosing to give away their product, newspaper owners have 
conditioned a new generation to believe that information is free-while allowing aggregators such as Google, Yahoo and the Huffington Post to reprint their work, and draw income from readers without any outlay in capital investment or personnel.

AS WE HAVE seen, the transmission of news has evolved many times in the past, from an addendum to the Sunday sermon, to the first news sheets, to small weeklies and dailies, published by dedicated editor-publishers determined to contribute to the political and social conversation of the time, to the penny press, to the modern TV newscast, talk-radio station and omnibus newspaper. The technology has evolved from hand press, to rotary press, to steam press, to offset, to Internet. And the craft has evolved from florid, literary musings, to the "razzle-dazzle" and muckraking of the penny press, to cold objectivity, to the intensive research and literary flourishes of the New Journalism, and back to objectivity and punditry. Finally, the business has evolved from cottage industry, to local cash cow, to publically owned chains answerable to a head office that is, in turn, answerable to shareholders. We also have seen that, as circulations were falling through the 20th century, profits were rising, providing an industry in decline with something of a false sense of well being-like the sense of warmth and relaxation that seizes a person on the verge of freezing to death.

Over all, the challenges for the business are apparent: Unless news companies find a way to attract a new generation of readers, and to extract a profit from their online readership, they may be on their way to extinction. There are obvious implications for democratic society in the question of whether they will survive, or 
die out and be replaced by something new.

THE NEXT chapter looks at the criticism of the press that has been rising since the Second World War, as the fortunes of the business have been falling, from the Hutchins Commission in the United States, through the introduction of the Social Responsibility Theory of the Press, to the Davey and Kent Commissions in Canada, to the rising chorus of complaints about press ownership and its effect on quality in the 1990 s and 2000 s. 


\section{Cries, curses, criticism \& complaints}

PIPPA NORRIS posits that political communication comes in three forms: civic engagement, agenda setting and persuasion (1999: 11-19). Each of these presents problems for journalism. Civic engagement implies that the press's role is to be society's information clearing house and political facilitator, something that may be better suited to such organizations as libraries, schools, citizens' movements, policy think tanks, NGOs and political parties. Agenda setting puts the press in the position of telling the members of its audience what they should be thinking and talking about - or what may be good and bad for them. This is a role that traditionally has won the news media few friends among the public or power brokers. Finally, persuasion is a job for advertisers and public relations practitioners, and can be interpreted as being more of a tool for agenda setting than a form of political communication unto itself. Also, such observers as Habermas (1992), Williams (1983) and Nader (1997) have argued that it is a practice that refeudalizes the Public Sphere, and is antithetical to a key institution that sees its mission as the preservation of democracy and free speech.

This chapter builds on the previous two by exploring the central issues in the criticism of the news media of the late 20th and early 21 st centuries, focusing on 1945 2006. This is a period marked by great concern over the impact of the press on the public discourse, from the U.S. Commission on Freedom of the Press, the Hutchins Commission, to just before the economic crisis that brought the media's economic 
structure to the centre of the conversation. As we saw in Chapter 2, those years also comprise an age of contradictions: declining circulation and growing profit; rising professionalism and falling morale; technological advantages and threats. It also is a period of growing concern about the uses and misuses of mass media in a modern society, from Hutchins's attempts to formulate a set of standards and practices and its offspring Four Theories of the Press, through government inquiries in Canada and Great Britain and the works of a horde of pessimistic late-century critics.

This survey of those critics and commentators is intended to pave the final few kilometres of road that leads to the recession of 2008 and its resulting panic. The aim, again, is to create a historical context into which we can place and better understand the current discourse.

TURNING BACK to Norris's three varieties of political communication: Civic engagement involves explaining to the public the issues and the parties' positions, and mobilizing citizens to vote. This implies a public-service role that the public may no longer need, or wish, the press to play. Via the Internet, political parties, interest groups, citizens' movements - as well as various forms of traditional and alternative media - have proved to be quite capable of getting platforms and policies to the people, discussing the issues, and promoting voter involvement. From a business perspective, this places the mainstream news media in the financially suicidal position of selling something everyone else is giving away. From a service perspective, it sets the press up to play the role of "gatekeeper" or educator, and to be seen by the public not as transmitting information but of controlling and interpreting it for what the 
members of the press-or the people who own one-perceive to be the common good. From a professional or craft point of view, it has tended to impose a humorless, pedantic tone, which readers and viewers often find patronizing, off-putting or soporific.

Agenda setting is even more problematic, in that it moves the press uncomfortably close to the machinery of power upon which it is supposed to be keeping watch. This involves a fundamental concern about the media in relation to democracy, and is an idea that brings us back to Lippmann and Public Opinion: that the media can't tell the public how to think, but it can dictate what to think about (1997: 206-207).

The third type of political communication, persuasion, implies that the press can be used to educate and enlighten, or to mobilize and proselytize. As we noted in the previous chapter, in its positive imaginings, this outlook has its foundations in Dewey's vision of journalists, social scientists and politicians coming together to take on the role of educators. Most recently, it found expression in the public journalism movement, which has declined in influence since its heyday at the turn of the 21 st century - perhaps because it never proved to be a cure for waning circulation, turned out to be fairly expensive to implement, and was adopted by online citizen journalists.

One thing all three forms of communication have in common is that they begin with the belief that there is some political state of grace to which we all should or could aspire, and that it is the media's duty to lead us to it (Dewey, Carey)-or at least keep democracy safe for us while we're at the movies or driving the kids to soccer practice (Lippmann, Schudson). Much of the criticism of the press dating back to 
Lippmann's Liberty and the News, Public Opinion and The Phantom Public or Dewey's The Public and Its Problems has revolved around those two points of view on the news media's role in democracy. At the same time, the fortunes of the press, and the concern about it, have run parallel to a similar concern about the health of democracy and the state of the Public Sphere. As we saw in Chapter 1, this led to the formation of this so-called Lippmann-Dewey debate over the relationship between communication and community.

Norris's three forms of political communication-at least as they manifest themselves in public journalism - encourage journalists to be active observers and passive narrators, to think of themselves primarily as citizens, educators, political activists, facilitators. Yet, there are other approaches to communication, political or otherwise, that may be better suited to journalism, such as record-keeping, bearing witness, interpretation, criticism and story telling. And these require a journalist to be a passive, but not necessarily neutral, observer and an active narrator-craftspeople or artists creating a documentary popular culture that explores both the mythology and the truth of their society. That is not to say that journalism is 'simply' story telling but rather that "the transfer of consciousness from one human being to another through a story, any story - from a journalist to an audience, in other words-produces the forms of public consciousness that make collective existence possible" (Adam, 2006:351). Or, to put it another way:

We tell ourselves stories in order to live.... We look for the sermon in the suicide, for the social or moral lesson in the murder of five.... We live entirely, especially if we are writers, by the imposition of the narrative line upon disparate images, by the "idea" with which we have learned to freeze the shifting phantasmagoria which is our actual experience (Didion, 2006b: 185). 
AS ADAM (2006) and Schudson (2003) have pointed out, forces within the craft and outside it-particularly the social sciences-have attempted to impose a formal mission on journalism, to put it to work as a persuasive force for agenda setting, or as a means to rally civic engagement. The most famous case is probably Four Theories of the Press, which was written by a trio of University of Illinois communication scholars in 1963 as a guide to the press and "the social systems in which the press functions" (1963: 2). It is a slim book that presents the idea that the news must always take on the character of the political system under which it lives-thus eliminating from the discussion alternative, underground or dissident press - and lays down the three types of journalism that exist according to political history of the postwar period, as well as a fourth, utopian viewpoint.

In 1995, another group of University of Illinois communication scholars, led by John C. Nerone, gathered to reassess the Four Theories and pose the question of "whether the whole enterprise needs to be rethought" (1995: 30). Nerone et al. argue that the theories are, for the most part, not theories at all, but rather "one theory with four examples."

Its theory, to paraphrase, is that, in its structure, policy, and behavior the communications system reflects the society in which it operates and that society can be categorically defined by a coherent philosophy. That is the basic postulate of the book (ibid.: 18).

This one theory is grounded in liberal tradition and neo-liberal worldview, growing out of a postwar concern about the rise of totalitarian states in the 20th century (Nerone et al., 1995). Three of the examples consist of: an Authoritarian concept of the press, growing from "centuries of authoritarian political thought from 
Plato to Machiavelli," (Siebert et al., 1963: 6); a Soviet Communist theory for the Marxist countries; a Libertarian theory for Western Europe (notably Britain) and North America. Merrill and Nerone (2002) argue that these examples have the virtue of offering a quick, simple survey of 20th century political systems, (for, as the Four Theories itself points out, the Authoritarian Theory can be applied to fascism). As such, the book has survived as a mainstay of journalism programs across North America, because it presents "a wonderful gift for students struggling to understand how a complicated world is supposed ${ }^{1}$ to operate" $(2002: 135)$. But it does so by invoking an "outdated canon of political philosophy" that flattens out differences among liberal thinkers and demonizes or discredits all non-liberal thinkers (ibid.). For example, it defines Marxist theory, more or less as Stalinism. It neglects to define Marxism, communism or the difference between the two, and never considers that "Marxist country \# 1 was different from Marxist country \# 2" (ibid:: 133).

The final and most influential theory, Social Responsibility, is poorly defined and full of contradictions and troubling consequences. It also has a distinctly jingoistic edge to it, arguing that "the U.S. was at least developing [from Libertarian] to Social Responsibility and implying that other systems were irresponsible" (Merrill, 2002: 133). However, the most worrisome aspect of the Social Responsibility Theory is that it can be used to justify the repression of free speech, or to co-opt the press to serve a special interest.

Look at the public journalists in the U.S. and the growing criticism of an "irresponsible press." Look at the meritocratic and paternalistic governments of Southeast Asia, especially Singapore. Look at the

\footnotetext{
'Authors' italics.
} 
socialist states of Vietnam, China and Cuba. Look at theocratic states such as Iran and to a lesser extent Egypt, Look at the paternalistic Arab kingdoms such as Saudi Arabia. Look at the unstable states in most of Africa. Their strict, often draconian press control is always justified by dragging out the concept of "social responsibility" (ibid.: 134).

The central premise of the Social Responsibility Theory is: "Freedom carries concomitant obligations; and the press, which enjoys a privileged position under our government, is obliged to be responsible to society for carrying out certain essential functions of mass communication in contemporary society" (1963: 74). Theodore Peterson, who wrote this section as well as the one on the libertarian press, identifies six tasks of a free press:

Servicing the political system by providing information, discussion, and debate on public affairs; (2) enlightening the public so as to make it capable of self-government; (3) safeguarding the rights of the individual by serving as a watchdog against government; (4), servicing the economic system, primarily by bringing together the buyers and sellers of goods and services through the medium of advertising; (5) providing entertainment; (6) maintaining its own financial selfsufficiency so as to be free from the pressures of special interests (ibid.).

So, the Four Theories of the Press comprise a useful teaching tool and rallying point for well meaning idealists, but they represent just one world view: free-market liberalism. And, rather than being a product of impartial scholarship, they embody the values of that liberal world view, which essentially is the story of Western civilization as told though its "great books and great thinkers" (Nerone et al. 1995: 17). For example, the "Libertarian Theory" - which evolves into the "Social Responsibility Theory"-is derived from Milton, Jefferson and Mill, and the "Authoritarian Theory" is most closely associated with Hobbes and Burke. Yet, as Nerone et al. argue, the 
theories are oversimplified and fail to allow for, or explain, areas of overlap-such as Hobbes, who proves it's possible to "share all the fundamental postulates of 'Libertarian Theory' as presented by Peterson and still call for authoritarian policies" (ibid., 20). Lippmann also could be taken as a case of overlap. His writings wander from Authoritarian to Libertarian, to Social Responsibility and on to a revival of Natural Law $(1978,1995,1955)$, and Dewey lurches from Libertarian in his spirit to Social Responsibility in his objectives (1954). And where does Gramsci's denunciation of the press as a de facto press office for the ruling elite (1971) fall in with the Soviet Communist Theory of state control of the media?

THE "SOCIAL Responsibility Theory" is the direct descendant of $A$ Free and Responsible Press, the 1947 U.S. report on freedom of the press, prepared by the Hutchins Commission, a panel convened at the request of Time-Life publisher Henry Luce and chaired by University of Chicago president Robert Hutchins. This, in turn, was the culmination of two decades of attempts by the news business and its critics among a growing journalism academia to codify a set of standards for the conduct of journalists and their employers. For example, in 1923, the American Society of Newspaper Editors adopted a code of ethics, the Canon of Journalism. Unfortunately, ASNE represented only newspaper editors in cities with more than 50,000 population, and the Canon didn't provide for any means of enforcement. Meanwhile, across the United States, journalists groups were organizing to set ethical and professional standards. The result, H.L. Mencken wrote, was that "the journalist was beginning to think of himself as a professional man" (Teel, 2006: 117). Unlike the other 
professions, however, he was not bound by any recognized, widespread set of professional standards. There were no licensing commissions, bar exams or Hippocratic Oath for reporters and editors.

The Hutchins Commission was, in part a reaction to some severe criticism that had begun to appear in post-World War II U.S. academia, such as Your Newspaper: Blueprint for a Better Press, published by the 1945-46 Neiman class, which accused daily newspapers of serving only "the class interests of their owners" (Davies 2006: 27). Another, even harsher critic was Ralph J. Cosman, director of the journalism program at the University of Colorado, who issued a "10-count indictment" of the press, which foreshadowed the work of Hutchins a year later (ibid.). Similar to the Motion Picture Production Code, the Comics Code or the U.S. TV networks' departments of standards and practices, the aim of the Hutchins Commission was to block government regulation by articulating an industry response to growing criticism of large media companies by the American public and government. As we saw in Chapter 2, those large media companies had been growing in size and power since the First World War. And there was a fear that the press barons presented, at least in potential, a dangerous alternative to democratically elected power, and that sensationalism and trivialization of the news posed a serious threat to democracy. The libertarian approach to the media, the criticism went, had led to "tendencies toward monopolization in the media ... and that commercialization produces a debased culture and a dangerously selfish politics" (Nerone et al, 1995: 77).

Over four years, the commission interviewed 275 observers, including many journalists, and in the end made a number of recommendations for the government, 
press and public, which it boiled down to five "ideal demands of society for the communication of news and ideas ..." (Hutchins et al., 1966: 31). They read like a blueprint for the Social Responsibility Theory of the Press. They dictate that the media should: deliver a truthful, comprehensive and intelligent account of the day's events in a context that gives them meaning; serve as a forum for the exchange of comment and criticism; project a representative picture of the constituent groups in the society; present and clarify the goals and values of the society; provide full access to the day's intelligence (ibid.). Unlike the Social Responsibility Theory, Hutchins did not mandate a role for the media in facilitating and preserving capitalism.

Given that those statements could be taken as points that simply define the best professional practices, one might have expected the industry to issue a collective grunt of approval and carry on. However, even though the report was the work of an industry-created committee, the U.S. media's response was not favorable. Publishers and editorialists denounced it as the beginnings of state control. Journalists accused the commission of being elitist -it consisted of 12 intellectuals and no journalists - and of "inviting government regulation, of unfairly lumping in radio and movies with the press, and of failing to conduct elaborate research" (Davies, 2006: 23).

However, the U.S. press, having a collective interest in enhancing its professional image, ended up adopting most of the commission's recommendations, "in practice (if not in theory)" (Nerone et al.,1995: 78). "Vestiges of social responsibility can be found all along the way, long before the Hutchins Commission. But who is to say this was social responsibility rather than just good business" (ibid.: 83). For example, publishers like Pulitzer and Hearst, and in Canada the Toronto 
Star's Hindmarsh and Atkinson families, had grown very rich and powerful addressing issues of social conscience.

Yet, for all their adoption of the principles of social responsibility, the growth in power and reach of the big media companies has repeatedly tripped alarms for academic theorists, industry critics and government. Acting on similar concerns to those that brought about by Hutchins, the United Kingdom and Canada have assembled several government inquiries to deal with similar issues surrounding the control and operation of the press by big business.

IN BRITAIN, the press tends to take itself quite a bit less seriously as a force for democracy and perhaps a little more seriously as a form of popular culture-or part of the conversation of the culture. At its lower levels, it enthusiastically embraces the idea of news as excitement, titillation and entertainment. As a result, official inquiries there have been highly critical of a press that, at those lower levels, can be almost frighteningly rabid and irresponsible by North American standards, and is more apt to degrade the conversation than contribute to it. Curran and Seaton (1997) note that the postwar press in Britain was faced with two options, neither of which it chose to pursue: follow the American example of social responsibility and journalistic professionalism, or adopt the European model and encourage competition through subsidies, grants and tax concessions to help sustain media outlets and stimulate competition. There are two problems with the first option, the authors argue. The way in which it "seeks to compensate for monopoly and chain ownership is in practice a way of legitimating the market system" (1997: 294), and the "evils" of chain 
ownership are much less apparent in Britain, which still has a healthy range of political points of view, at least among its four main national dailies. That option also "has radical implications in that it celebrates objective journalism and professional autonomy and runs counter to the hierarchical, partisan tradition of the British national press" (ibid.). The latter option, they continue, is difficult to implement because it also clashes with the British tradition of having no press policy (ibid.). Commenting on this condition, Raymond Williams wrote:

There is now no difficulty in agreeing that there is a crisis in the British press ... When it comes to remedies, of course, this unity does not last, and we have a familiar situation of British society over the last twenty years, in which there seems to be an almost functional relation between general recognition of the need for change and a persistent inability to make any real changes. Thus our years are punctuated with deep crises, decisive turning points, in-depth enquiries, radical reorganisations and bold new starts which, as they settle, and as the general problems persist, fade into the angry banalities of cynicism and frustration. This mood, which is now so prevalent, does not exclude, however, the further opportunism of yet newer starts, yet broader turning points, yet in-deeper enquiries. The crisis, at most levels, comes to feed on itself (1978: 15).

WILLIAMS COULD have been describing the situation in Canada, where the hand wringing over concentration of ownership has lasted almost a half-century and the striking of official inquiries has become a periodic make-work project for politicians and bureaucrats. To the media organizations and their allies, the criticism of chain ownership represents the alarmism of old-fashioned thinkers mired in the quaint notion of the locally owned newspaper, which has become an anachronism in a global world. Yet, the feeling persists among many media critics that a "market-driven media system is unlikely to overcome its own biases in favour of affluent consumers, consumerist 
lifestyles, and seemingly apolitical but sometimes socially corrosive entertainment" (Hackett and Zhao, 1998: 158).

There have been three major news-media inquiries in Canada: a Special Committee, chaired by Senator Keith Davey in 1970; a Royal Commission on Newspapers, chaired by Tom Kent, in 1982; a Report on the News Media, by the Standing Senate Committee on Transport and Communications, chaired by Senator Lise Bacon, in 2006. They all investigated the concentration of ownership in the newspaper business with relation to its implications for commerce and democracy, and delivered a number of recommendations, which have been mostly ignored. The notable exception is the system of provincial press councils that grew out of the Davey Committee and to which the public can appeal when it feels itself the victim of media injustice. Onetime Toronto Star ombudsman Borden Spears, who sat on the Kent Commission, might have been writing a conclusion for all the reports with this comment on the effects of chain ownership on the craft of journalism:

The process of corporate growth, by concentration into larger groups within the industry, has been accompanied by a reduction in the diversity of news and comment that is the vital element of a free society. The quality of what remains has not improved, and in some respects has declined. ... Innovation, creativity, even a desirable degree of eccentricity give way to the pressures of uniformity (1984:4).

Compare that to this quote from the report of the Davey Committee, 14 years earlier:

The most insidious effect of journalistic monopolies, however, is the atmosphere they breed. Every reporter soon learns that there are only a few newspapers where excellence is encouraged. If they are lucky or clever, or restless, they will gravitate to those newspapers. If not, they will stay where they are, growing cynical about their work, learning to live with a kind of sour professional despair. Often, you can see it in 
their faces. Most Canadian city rooms are boneyards of broken dreams (1970: 65-66).

And, finally, to the Bacon report, 22 years later:

While the committee recognizes the importance of sustainable news media organizations, it does not agree that the unfettered free market is as optimal or benign as its proponents sometimes argue.... [T] he Committee has seen evidence that there are news media organizations with excessively dominant positions within individual Canadian markets. Such concentration of ownership could have negative consequences for the public interest. The lack of appropriate regulation has led to the present situation (Bacon, 2006: 7).

It's interesting that Davey and Spears highlight how chain control stifles professional and artistic ambition, and how all three warn of its negative effect on social responsibility, and argue for public policy to control it.

The most famous of these, the Kent Commission, came into being to deal with accusations that the Thomson and Southam newspaper companies had colluded to reduce competition. With 77 percent of Canada's dailies in chain hands, the commission recommended that proprietors be limited to no more than five newspapers, the circulation of newspapers owned not exceed five percent of the circulation of all dailies in Canada, and the point of publication of any acquired newspaper not exceed 500 kilometres from any other paper under the same ownership (Kent, 1981: 239). The recommendations resulted in the proposed Canada Newspaper Act of 1983, which was scuttled by newspapers' lobbying, in the name of freedom of speech, and against government controls. In his commission's report, Kent wrote:

In a country that has allowed so many newspapers to be owned by a few conglomerates, freedom of the press means, in itself, only that enormous influence without responsibility is conferred on a handful of people. For the heads of such organizations to justify their positions by 
appealing to the principle of freedom of the press is offensive to intellectual honesty (ibid.: 217).

In the end, Kent wrote, the recommendations "came to nothing except the production of useful material for journalism students" (1996: 22). Still, he argued, "powerful vested interests can be overcome, when the public interest is asserted against them, because there are moments when circumstances temporarily weaken them. That was true of the newspaper industry during the transactions of 1980 " (ibid.), when Thomson and Southam closed competing newspapers and created monopolies in two cities in a single day.

AS OTHER commentators have pointed out, media concentration tends to ebb and flow, and specialty television and the Internet have certainly provided far more diversity than any of the inquiries anticipated. Unfortunately, there has been little discussion of the quality of this diversity, or if there is truly a diversity of content among the diversity of formats. For example, the increasing concentration of ownership of television networks and specialty stations - to the point that virtually all Canadian private English-language television is owned by three corporations-has provided a wonderful opportunity for parent companies to extract more profit from content by reusing programs across platforms. For example in the Bell Media world, a nature show that airs on Discovery Canada can be rerun on Discovery Science, Discovery World, Animal Planet and CTV. Similarly a drama that airs on Global can be repurposed for Showcase, Slice and even History (if there is even the slightest historical content). Yet commentators who simply count channels constantly come to the conclusion that there is more variety than ever on the TV dial, when the 
standardization of programming may, in fact, be producing less. Similarly, newspaper chains that centralize functions such as federal political reporting, editorial writing, analysis, major league sports coverage, and TV and film criticism produce the illusion of plenty while delivering less-as does the proliferation of aggregation sites, which simply repurpose existing news.

Many commentators, especially on the left (Gramsci, Williams, Chomsky, Herman, McChesney, Bagdikian), have concluded that news corporations "influence their audiences' perception of public life, including perceptions of politics and politicians as they appear-or do not appear-in the media" (Bagdikian, 1990: 5-6). This is a long-running complaint. In 1920, in The New Republic, Walter Lippmann and Charles Merz published "A Test of the News," a content analysis of the New York Times' coverage of the Russian Revolution from 1917 to 1919 . The authors analysed "thirty-six months and over one thousand issues" of the Times (2007: 154) and discovered that the paper had been handed most of its information by the U.S. State Department and anti-Bolshevik Russian agencies. The authors accused the paper of filtring that information through the ideology of the paper's owners and managers, to present an unfavorable view of the Bolsheviks. "The chief censor, the chief propagandist," they wrote, "were hope and fear in the minds of reporters and editors" (ibid: 158). Warning that "the reliability of the news is the premise upon which democracy proceeds," (ibid.: 159), they argued that a journalist who readily accepts facts handed down from official sources is about as useful to the public as "an astrologer or an alchemist" (ibid.:172). 
Roughly 70 years later, Edward S. Herman and Noam Chomsky used content analysis to paint a picture of a North American press that designates whether a subject is "worthy" or "unworthy" according to the ruling ideology. For example, in comparing the New York Times' coverage of the Khmer Rouge in Cambodia (a murderous regime that was Maoist, and therefore hostile to the United States, and tended to receive unfavorable coverage) and Indonesia (a U.S. ally, whose brutal treatment of East Timor was almost ignored), they concluded that the close relationship between the people who own the media and those who "fund them as advertisers" plays "a key role in fixing basic principles and dominant ideologies" (1988: xi).

This observation tends to be reinforced by the way mainstream journalism reflects reigning societal values. Daniel Hallin describes the world of journalism as being "divided into three regions, each governed by different journalistic standards." He calls these the spheres of "consensus, legitimate controversy, and deviance." The first is "the region of motherhood and apple pie," and inside it, journalists feel free to act as partisan commentators, upholding the values of their society, and acting "as advocate or celebrant of consensus values." In the second, "balance and objectivity reign as the supreme journalistic values." This is where journalists feel compelled to present the various sides of an issue as being of equal weight and importance. Finally, on the outer fringes, lies the sphere of deviance, a "realm of those political actors and views which journalists and the political mainstream of the society reject as unworthy of being heard" (1989: 116-117). 
Hallin was talking about the way the antiwar movement of the 1960 s moved from the third sphere to the first, but there are many worthwhile topics of discussion that have resided at least for a while in that last zone. Topics in the sphere of deviance, Schudson (1995) points out, are accepted as being so far outside mainstream thought that they can be freely dismissed or ridiculed in print or on the air. The example he uses is the women's movement of the 1960s and early '70s - when newspaper columnists referred to feminists as "women's libbers" or "bra burners," and wrote 'witty' opinion pieces about their place being in the kitchen. A more recent example might be the near-hysterical response to Barack Obama's 2008-presidential-campaign suggestion that Americans "share the wealth." This triggered a discussion in the U.S. media that was entirely about whether Obama's comments were socialist in nature, and never about what socialism is or how it works, an understanding of which seems rather important to the discussion as it was being framed. An example of a story that moved from the sphere of deviance into the sphere of legitimate controversy with uncommon speed might be the Occupy movement of 2011, which was treated at first as the exhibitionism of kooks and political extremists, until the press began to realize that it expressed the feelings and opinions of most of the population and, therefore, most of their readers and viewers.

Without imposing any ideological interpretation, central to Hallin's analysis is that this sort of structure tends to trivialize or isolate eccentric, novel or contrarian positions, limiting or slowing their entry into the public discourse, or keeping them out completely. The way Schudson explains it, "The chain owners are not so much 
politically conservative as risk averse, which generally comes down to the same thing" (1995: 175).

Meanwhile, Bagdikian and Chomsky describe the process that produces ideology in a media organization as being one of indoctrination into that sphere of legitimate controversy, or shared values. This is Chomsky's:

[T] hose who occupy managerial positions in the media, or gain status within them as commentators, belong to the same privileged elites, and might be expected to share the perceptions, aspirations and attitudes of their associates, reflecting their own class interests as well (1989: 8).

BY EXTENSION, one would expect those managers to hire news executives who share their values and, in turn, hire reporters and editors who share theirs. The average media baron, the argument goes, has no time to dictate the editorial policy of each newspaper under his command-much less vet each story that appears in each paper. This argument implies a benign neglect on the part of the top management of newspaper chains: As long as the papers turn a profit, they're free to pursue any editorial policy and practise any management philosophy they choose. However, as David Taras points out, it is not necessary for an owner to have his hand in the daily running of newspapers, because owners hire managers in their "own image" (1999: 213). He quotes David Radler, president of Conrad Black's Hollinger Inc., which controlled dozens of Canadian newspapers in the 1990s—including most English-language big-city dailies outside Toronto: "[I]f editors disagree with us, they should disagree elsewhere" (ibid.). Any media company-like any organization-that wants to enforce a set of standards and practices throughout its operations need only select a handful of 'right-thinking' individuals and place them in key positions. 
In 1999, Taras pointed to three developments that he argued had transformed much of Canadian journalism into a mouthpiece for the new right: the rise of neoconservative pundits such as Diane Francis, William Watson, Peter Worthington, Barbara Amiel, David Frum and Andrew Coyne; the expanding power of Conrad Black and Paul Godfrey, then head of the Sun Media newspaper chain; the emergence of right-wing think tanks such as the Fraser Institute. In fact, Taras was breaking one development down into its components: the control of most of the nation's print media by companies that choose to champion a neoconservative ideology. He went so far as to write that most of the print-media political discourse in Canada was being narrowed to reflect the viewpoints of Godfrey and Black, whom he defined as right-wing corporate ideologues. Thus, Taras argued, "a right-wing agenda dominates public debate" (ibid.: 22). It's interesting to note that the situation is not much altered today, though the players have changed positions. Godfrey is running the Postmedia chain, the remnant of the Southam/Hollinger/Canwest group. Sun Media is now a division of Quebecor, run by the extremely right-wing Pierre-Karl Péladeau, which in 2011 launched the Sun News Network, a Fox-news-type forum for neoconservative ideology. Black is out of the media business.

Political analyst Lawrence Martin has repeatedly pursued this argument that the ideological bent of the Canadian media is out of step with the prevailing views of Canadians. Writing in 2003, after Black had divested himself of his newspaper holdings by selling off to two other companies, Martin echoed what Taras had written in 1999: That almost all of Canada's media — specifically, Canwest, the Sun chain and Quebecor in general, the National Post and the Globe and Mail-were right-leaning and pro-American. And most of the major commentators and pundits "slant right." Yet, "Canadians, as 
opinion samplings suggest, haven't migrated rightward in big numbers. It is a question of balance, and the balance-does the NDP have a chance in this media environment?-is gone. The impact on traditional Canadian values can only be corrosive" (2003).

Conversely, the Fox news network slogan, "Fair and Balanced," is a response to a perception among conservatives that most U.S. media businesses have a liberal bias. By favoring the far-right agenda, the network argues, it balances the debate and creates fairness to what it contends is an under-represented point of view. However, one would be hard-pressed to find anything among the prominent North American media that is as far left as Fox and Canada's Sun News Network are to the right. It's a considerable stretch to argue that poorly financed fringe publications like Mother Jones or Truthdig might present an alternative to Fox News.

All of this harks back to the 1920s, when Lippmann, in Public Opinion, foreshadowed Chomsky by noting that newspaper publishers are businessmen who tend to sympathize with the advertiser and mistrust the loyalty of the reader, and "honestly see the world through the lenses of their associates and friends" (1997: 206). Lippmann's misgivings about the press date back to one of his earliest works, and extend through most of his life. In fact, he produced a defining statement in media criticism in Liberty and the News, his earliest book on the subject.

So long as there is interposed between the ordinary citizen and the facts a news organization determining by entirely private and unexamined standards, no matter how lofty, what he shall know, and hence what he shall believe, no one will be able to say that the substance of democratic government is secure (1920: 7).

It's a shame Lippmann didn't live to meet A. Roy Megarry. As publisher of the Globe and Mail in the late 1980s, Megarry predicted: "By 1990, publishers of mass 
circulation daily newspapers will finally stop kidding themselves that they are in the newspaper business and admit that they are primarily in the business of carrying advertising messages" (Miller, 1998: 30). Megarry's comments describe how owners and publishers of the 1980 s and ' 90 s were fine-tuning the two-tier newspaper manufacturing process, to place the emphasis on the advertiser, rather than the reader. In this world, editorial material is no longer there to sell the newspaper to the reader by providing a service to that reader, but exists as bait, to deliver consumers to commerce. Thus, sections that could provide useful information, criticism, discussion and analysis - such as travel, fashion, food, real estate, automotive, entertainment and business - are turned into congenial environments for advertisers (Bagdikian, 1990, Underwood, 1995).

The fashion section ... is an annual flood of gushy promotion of exotic garments, all in a "news" section. ... The same is true of travel and usually food sections. A survey in 1977 showed that 94 percent of food editors use food company press releases for recipes and 38 percent attend food events at the expense of food companies. The growing trend among newspapers to turn over sections of the "news" to the advertising department usually produces copy that is not marked "advertising" but is full of promotional material under the guise of news (Bagdikian, 1990: 165-66).

It's easy to see how this focus on the ratio of 'eyeballs' to advertising might lead to accounting formulae that focus on minimizing the cost of content as a way to raise the bottom line. Habermas (1991) would describe this as proof of the refeudalizing process, as the embodiment of the information culture transformed into an advertising one. Williams (1983) would dismiss Megarry and his like as cheapjacks. 
THE TENSIONS in the news business of the 1980s and ' 90 s weren't solely between business and editorial, though. There was serious strain among the various players in the newsroom itself. Objectivity had re-emerged as a convenient tool for a new breed of professional editors who wished to tighten their control of the lumpenproles under their command. Many were dedicated, as Spears (1984) noted, to stamping out "[i|nnovation, creativity, even a desirable degree of eccentricity" and replacing it with uniformity. Philip McLeod, then editor of the London, Ont., Free Press, might have been writing a eulogy for the New Journalism, when he said:

Sometime in the early 1970s, newspaper reporters started thinking of themselves as writers. But their job is to dig out information that somebody has asked for. We're in the reporting business. If you want to write, go work for [sic] a book (Underwood, 1995: 173).

McLeod's attitude towards his staff wasn't unusual or notably unenlightened by 1980 s-'$^{\prime} 90$ s standards. Resentment was widespread, to the point that a 1991 U.S. national survey found that "inept managers" were the leading cause journalists gave for leaving the business (McPherson, 2006: 111). Newsrooms that had been accustomed to editor-managers were finding themselves being run by manager-editors. Some were career newsroom managers, who had never been in the field as reporters; some were journalists, who had been co-opted into a management style with an emphasis on budget, graphic design, promotion, and management by objective. The last involved annual contracts in which editors would establish for their publishers annual goals - usually involving things like budget control, circulation growth, personnel deployment, everything but editorial excellence.

Many journalists are finding it tougher to question authority out in the world when they are being pressured to become loyal corporate soldiers inside their organizations. To fit into the newspaper's design and 
packaging needs, preplanning is essential and reporters are expected to fulfill their role within the system dutifully and without complaint. Editors, who need to allot space in the news pages well in advance, prefer stories that are predictable, come in with plenty of lead time, and fit the preconceptions that have already been discussed in editorial meetings ... No matter how fervent their protests, the lives of newsworkers have become increasingly circumscribed by performance standards and management systems designed to insure greater productivity, by bosses trained in the new techniques of scientific management, by readership surveys, and by editors who have joined the marketing team (Underwood, 1995: 63).

Thus, by the mid-1990s, newspapers had begun to turn to the "total newspaper approach" to lure back their readers. In this scenario, the news and business departments of dailies coordinate their activities to market their product, which is "a boon to business-side people, whose influence within the news organization has expanded greatly" (ibid.: 16). One manifestation of this approach was the fact that focus groups, surveys and polling came to play a significant role in editorial leadership. Critics complained that newspaper managers sometimes seemed to expend more energy asking readers what they wanted to read than delivering it. Alison Carper defined this as a particularly self-serving form of false empiricism: It's quite a simple - albeit expensive - matter to hire consultants to carry out content analyses, set up focus groups, design surveys or create study groups, or to redesign the product to make it 'more accessible' or 'youth friendly.' The problem with much - if not mostof this sort of so-called research is that it is not objective. It's client-directed. So, the aim is to satisfy editors' and publishers' hunches and prejudices and not to uncover any objective empirical proof of anything. As a result, the researchers "pretenses to scientific rigor are undermined by their own subsequent pronouncements" (Carper, 1997: 61-62). Even when it is objective, market research gets in the way of solid 
newsroom management by shifting the focus to what readers liked yesterday, rather than what they will like tomorrow. The result is boredom: you give readers what they already have, and never surprise them with something new. New Yorker editor William Shawn argued that the "whole thing begins to be circular. Creativity and originality and spontaneity goes [sic] out of it. The new process is to discourage the creative process and kill originality" (Bagdikian, 1990: 112). As former Philadelphia Inquirer editor Charles Layton wrote:

Over the past 20 years, at their annual conventions, and in their trade magazines and in-house publications, news executives have spoken more and more of the need for journalists to think like marketers. As if it were easy, or possible, to know in advance what people want to read. As if the average citizen, in a brief telephone survey conducted by a part-time, poorly paid, not-very-well trained surveyor, could articulate that. And as if compelling content somehow originated with readers and not in the individual mind of a journalist with interesting things to say (1999).

Not surprisingly, many editorial workers who formerly had been untouched by corporate planning would have preferred it remain that way - as is illustrated by these quotes, about a decade apart, from articles in two trade magazines. First, Bill Gloade's "Stress has significant presence in newsrooms," Editor and Publisher, Nov. 12, 1983:

Fifteen years ago, editors were editors. Today, they are editormanagers. They direct the editing of the newspaper with one hand and, with the other, they are deeply involved in business management. This editor is expected to carry on in the best traditions of journalistic excellence, but also is expected to share the responsibility for the newspaper as a "profit center." Many editors discovered that this dual obligation created unfamiliar stresses (Underwood, 1995: 29).

Second, John McMillan's and Jonathan Kwitny's “The high cost of high profits," Washington Journalism Review, June 1990:

We too often have corrupted the city desk with those "endless imbecilities of high command." Instead of talking to a reporter, the city 
editor audits time cards. Instead of editing copy, the city editor writes a memo about expense accounts. Instead of reading the competition, the city editor goes to a management meeting. ... I submit that we run the risk of alienating our basic resource - reporters (ibid.: 31).

THE FEELING among many observers was that economics was fuelling a poisonous blend of caution and desperation, a constant search for a no-risk editorial panacea and an obsession with managing expenses. In most newsrooms, though profits were high, there was a quiet desperation over sliding circulation. Meanwhile, newspaper chains were creating large debts through acquisition, and leveraging profitability with public stock offerings. The main effect was to place more pressure on companies and individual media holdings to service debt and perform up to the "rising tide of shareholder expectation - a demand for ever-improved return on investment that's relentless whether a newspaper is publicly owned or privately held."

However a family that owns a privately held newspaper often has lived for generations in its town and feels a responsibility to ensure the newspaper serves its town well. Shareholders of publicly owned companies usually have no more commitment to newspapers than to any other investment, and often they live far from towns where their companies' newspapers are published (Fink, 1996: 19).

In 1986, for example, merger banker Christopher Shaw said a daily monopoly newspaper with a 15 percent annual operating profit could, within two years of purchase, be turned into a 40 percent-profit newspaper through cutting costs and raising advertising rates and subscription prices. "No one will buy a 15 percent margin paper without a plan to create a 25 to 40 percent margin" (Bagdikian, 1990: 6).

If long-term profits and stability come from local news and larger portions of detailed and analytical news, why have newspaper publishers gone in the opposite direction? The reason is not irrational if short-term profits are the goal ... Unfortunately, short-term profits are 
now imperative in the major media almost without regard for the future of the media institutions. Newspapers no longer depend solely on their readers. They must satisfy advertisers, Wall Street investors and parent corporations (ibid.: 200).

In 1980, the U.S. Newspaper Research Project delivered the first in what was to be a long line of prescriptions for this ailing industry, in the form of a report called Changing Needs of Changing Readers, a \$4 million undertaking that comprised some 70 research projects conducted over three years. In it, researcher Ruth Clark urged editors to revamp newspapers to help readers cope with their lives - to produce, in the vernacular of the time, "news you can use." She said readers: craved good news; were busy and wanted news in easy-to-digest nuggets; liked newspapers that were well organized, well designed and easy to navigate; wanted predictability, with anchored features and standard placement of articles (Underwood, 1995: 7).

The belief that Clark had found the antidote to TV-bred short attention spans led to a series of trends, that gained momentum when the Gannett newspaper group deployed virtually all of Clark's recommendations in its founding of USA Today in 1982. With its bite-size stories, soft-feature content, chatty reader friendliness, obsession with weather and flashy layout, America's first mass-market national newspaper was "the quintessential product of modern corporate media engineering."

Critics of USA Today complain that the only vision at the heart of the newspaper is a marketer's vision. They condemn the newspaper for its overemphasis on packaging, graphics, brief text, factoids, flashy color, and news summaries in lieu of in-depth reporting. But editors en masse have followed the newspaper's lead in appealing to busy Americans who (their research tells them) aren't taking the time to read. In a report for [the U.S. industry society, the Associated Press Media Editors] in 1983 , more than 100 newspapers reported a variety of changes in news editing, reporting and production as a result of competition from USA Today (ibid:: 96). 
As the New York Times pointed out, USA Today was "loudly mocked and quietly mimicked" (McPherson, 2006: 31), leading to an epidemic of fact boxes, splashy colours and chatty stories in dailies across North America.

Then, in 1984, at a convention of the American Society of Newspaper Editors, Clark fired another shot, and sent the herd stampeding in a different direction. This report was quickly nicknamed Ruth Clark $I I$, and in it she revealed that readers no longer wanted news they could use, but craved material that would help them understand a complex world: hard news, health, science, and technology (ibid:: 11). Meanwhile, Leo Bogart, retired executive vice-president of the U.S. Newspaper Advertising Bureau, released the results of a 1983 survey of 1,310 U.S. newspapers. He had found that two out of three had made substantial changes to editorial content and design, and 71 percent in graphics and layout since 1979. One-third had altered significantly the ratio of hard news to features-opting two-to-one in favor of more "reader-driven" features, as well as more sectionalizing, regional zoning and marketing to upscale readers (ibid.: 10). None of this had turned the tide of declining circulation. Like Clark, by the mid-1980s, Bogart was reporting that readers were craving more substance in their daily newspapers, and less how-to and selfimprovement material. The real pressing issues facing newspaper publishers, he claimed, were pricing, delivery, service and conditions over which newspaper executives had no control, such as the price of newsprint. Bogart argued that newspapers had the best chances for renewal if they concentrated on performing their traditional functions well and forgot about the graphic and marketing gimmicks. He 
wrote, "It's fantasy to believe that a newspaper can be packaged like a bar of soap or a can of dog food, or even like a television news program. Its symbolic texture is too complex for that; its elements are too rich" (ibid.: 11).

THROUGH THE 1980s and '90s, a chorus of critics leveled attack after attack at the news business "for being shallow, confrontational, inaccurate or incoherent" (Bird, 1997: 1). One observer (with an eerie prescience for the kind of sloganeering that would dominate the discourse a decade later) delivered a eulogy titled The End of News, the thesis of which was that news had become "less reliable and less relevant ... destined to occupy a smaller and smaller part of our cultural map. Information is becoming more important than news to those who have money and power" (ibid.). Underpinning much of this conversation was a sense that some ineffable, illdefined characteristic that connected a newspaper with its audience had been lost. In 1999, the U.S. Project for Excellence in Journalism commissioned Carl Sessions Stepp to compare American newspapers from the early 1960s to those of the late ' 90 s. He found the papers of the ' 60 s to be "homely and drab," often badly written, disorganized, "jam-packed with short items, overflowing with local names, places and activities." The average length of a story was six inches and written in the oldfashioned inverted pyramid style, with one or two longer, more reflective pieces being the norm (Stepp: 1999).

Two things stand out, in terms of the trends of Stepp's day. Through the 1980s and '90s, there had been a constant refrain that the modern attention span had shrivelled, and readers wanted information quickly and concisely. The greatest success 
stories in modern North American journalism - the creation of Le Journal de Montréal and the Toronto Sun in Canada in the 1960s and '70s respectively, and of USA Today in the 1980s - would seem to bear that out. Yet, Stepp's research indicates that readers have long expected newspapers to be concise in most stories, and to offer in-depth analysis only for the two or three more important issues of the day. Second, the fact that the old dailies were "overflowing with local names, places and activities" plays to the argument of the proponents of public journalism that dailies had ceased to act as citizens in their communities - though it falls short of supporting the kind of activism for which those promoters of public journalism were calling. Stepp's research showed that the newspapers of the late ' 90 s were more comprehensive, offered more in-depth reporting, were more conscientious in getting the story right, were better organized, and were more attractive in terms of photography and graphic design. Yet, he invokes that sense of loss that permeates so much of the discourse.

Beyond the hard data, a close reading ... yields signs of the newsroom anxieties that have been documented elsewhere in the State of the American Newspaper series, and which I have seen first hand in a decade's worth of editorial consultations. These include increased mistakes in copy (tied to such factors as reduced quality control and overstretched copy desks), demoralization over rising productivity demands in an age of downsizing and cost cutting, and a clash between marketing and public-service mindsets. Forces like these have plunged the industry into a crisis of confidence at a time when many papers are, arguably, at a peak in terms of quality. Yet one wonders at heart if it isn't an intangible that should be an even greater worry: the question of personality and connection - that essential and ephemeral quality that can make the difference between readers speaking fondly of "our paper" or simply "the paper." ... [A] strong perception lingers that some essential local ingredient - be it a fixed sense of region, state, or even state of mind - has been lost (ibid.). 
Stepp is quoting Carey: “ 'My newspaper' of older usage became 'the newspaper'; it had severed its allegiance and contact with the public" (1997d: 249). Carey's fellow proponent of public journalism - and still a harsh critic of modern news media - Jay Rosen has argued that reporters and editors had taken to sitting in the grandstands and "jeering the idiots." This had created "a sorry spectacle, a game of 'who's up and who's down,' a public comedy played by villains and fools, scored by journalists who believe they're above it all" (1999: 224). Rosen complained that newspapers, when they are not preaching to the converted, often are creating readers that "find only further estrangement in the news, which treats politics as a game to be played by insiders and pros" (ibid.). Similarly, in Canada, Miller complained that readers were becoming repelled by the negative tone of daily newspapers:

Traditional journalism follows a script, identifying, decrying and demanding solutions to problems encountered by covering other powerful vested interests in society. Frequently, it adds to society's confusion, hopping from one dose of bad news to another as if it were delivering bodies to what one editor calls the emergency room of the mind (Miller, 1998: 218).

As the 20th century was coming to a close, Rosen wrote, journalists were faced with the question, "Do they want merely to entertain the public or engage it?" $\mathrm{He}$ invoked James Fallows, Washington editor of the Atlantic Monthly, from his book Breaking the News: How the News Media Undermine American Democracy, who predicted that chasing readers would lead to a race to the bottom. Once "people see no point in paying attention, journalism will have to transform itself into something else: entertainment. But the press cannot hope to compete with the entertainment culture, with its lurid diet of celebrity news and sensationalism. In flunking the political test 
before it, the press will fail commercially as well" (Rosen: 1999: 224). This sense of pessimism further resonated at an August 1999 meeting of American journalism educators in New Orleans, where media lawyer Bruce W. Sanford warned attendees that the news business was in "a dangerous new season." The core values of honesty and accuracy were being eroded by the rush to get a juicy story first, and that news was being replaced by argument, commentary, chat and speculation (Meyer: 1999).

ANOTHER CRITICISM of the news media at the turn of the century was that they were interested in an audience made up only of the affluent - which stands to reason for an industry in incipient financial panic. Increasingly, it is only the affluent who are an audience for advertising. Critics complained that this was creating an echo chamber for the rich and powerful, and disenfranchising everyone else.

The media system is linked ever more closely to the capitalist system, both through ownership and through its reliance upon advertising, a function dominated by the largest firms in the economy. Capitalism benefits from having a formally democratic system, but capitalism works best when elites make the most fundamental decisions and the bulk of the population is depoliticized. For a variety of reasons, the media have come to be expert at generating the type of fare that suits, and perpetuates, the status quo (McChesney, 1999: 3),

Many late-century critics described this pursuit of the affluent as a disaster for newspapers, society and democracy, that the process of appealing only to the well off "leads to news content that is less and less relevant to blue-collar citizens who were once reliable newspaper subscribers. The newspaper, in short, in its upscale move, has significantly authored its own irrelevance" (Schudson, 1995: 182). While owners convert their papers into "primarily carriers of advertising, advertisers want affluent 
readers between the ages of 18 and 49" (Bagdikian, 1990: 199). This means newspapers control the readership by gearing their coverage to reflect the audience in affluent neighborhoods, where they promote their circulation. At the same time, they cut back on reporting of neighborhoods without the desired demographics, primarily where low-income people and the elderly live.

The 'unwanted American population' that is systematically discouraged by advertising-supported media is not small. In 1984, families with less than the median combined income, an undesirable income level for major media, constituted 50 percent of all American families (ibid.).

This was an important concern in Canada, too, where the 1990s saw an astonishing level of concentration of ownership. One owner, Conrad Black's Hollinger Inc., controlled the quality broadsheet business outside Toronto, Winnipeg and Halifax, with only the Globe and Mail to offer any competition. Ottawa Citizen editorial page editor Peter Calamai - who was dismissed after the Hollinger takeover in the mid1990s-described Black as a man who "thinks what matters is speaking directly to the people who have influence, speaking directly to the people who have their hands on the levers" (Miller, 1998: 78). Black's wife, newspaper columnist Barbara Amiel went so far as to tell a meeting of the Canadian Association of Journalists that the "newspapers that will survive and prosper are those we take up-market" and that it was "time for newspapers to turn into cultural, literary and public affairs experiences for those large numbers of sophisticated readers who want that experience" (ibid.).

The other side of the debate was that newspapers had no choice but to follow the affluent as they abandoned city cores. This was forcing "dramatic changes" in the structure of newspaper audiences, with cities growing out and annexing affluent 
populations, and with other affluent residents fleeing farther from the city cores.

"Roughly two options are open to a newspaper that is anchored downtown ... adjust to market change and follow the affluent, recapturing them in the suburbs, or ... wither and die" (Fink, 1996: 37).

Either way, the large dailies were cutting a large segment of the population out of the conversation of the culture-and rendering their activities irrelevant to that conversation. The implications of this are obvious, if you consider that many social, commercial and cultural trends in society tend to bubble up from below, and that the upper layers of society have little to gain through innovation and everything to profit from preserving the status quo. As for the newspaper business, it would seem that by alienating this loyal audience of blue-collar readers the dailies were also driving them into the arms of the Internet and the all-news networks.

WHAT WAS less clear was how the owners and publishers could have got the Internet so wrong - especially considering the fact that newsrooms had been receiving material electronically from the wire services since the early 1970s. As we saw in Chapter 2, the newspaper companies did have a knack for misreading the technology, from implementing the baffling audiotext systems to giving away their most valuable resource online, to overlooking the value of online classified advertising. As late as the mid 2000s, the 'content provider' model was more or less the only means of adaptation newspapers were considering-and, even then, often tentatively. In early 2000 , newspaper consultant Christine Urban, of the U.S. company Urban \& Associates, warned that newspapers were being far too slow to adapt new technology to their 
purposes, and to adapt their product to the new technology. She suggested that daily newspapers should: develop different Web sites for different sections; repackage sports news in a weekly online magazine; distribute free, abridged, digest editions for commuters; accelerate their rate of innovation, bringing new projects online within six months of inception. "The concept of having new products designed to cannibalize some sections of newspapers is anathema," she said. "I say being cannibalized is better than being eaten by another species, and at least you still get the protein"(MacAfee, 2000).

At the same time, the newspapers' search for a saviour technology extends back at least to the turn of the 21 st century, when the 'killer app' was supposed to be the portal.

Portals refer to the Internet services that people use to start their trek through cyberspace. They bring order to the Internet experience. More than browser software or the standard ISP, portals organize the entire Web experience and provide a "search" mechanism to bring Internet material to users as painlessly as possible ... the key elements for a portal are to have e-mail, a search engine and easy access to ecommerce. Exclusive or semi-exclusive rights to popular media content does not hurt either ... (McChesney, 1999: 163-164).

The fact that the notion of a portal defies the logic of the Internet appeared to be lost on the media executives who embraced it in the early 2000 s. In the hopeful world of executive Webspeak, terms like "brand," "portal" and "toolbox" were thrown around like incantations, with no regard for the fact that someone surfing the Web has more freedom of choice than a person browsing a magazine or newspaper, or doing laps around the TV dial. Web browsing is active, omnivorous and omnidirectional, and the last thing the average Web browser wanted was someone to "bring order" to it. 
Reading the latest news no longer involved the linear process of receiving and digesting one news package assembled by an editorial team, or even several news packages assembled by several editorial teams, but searching and collecting fragments from a variety of sources, which can span the globe and a variety of political and social viewpoints. As we'll see in the next chapter, the Web sites that are prospering are the ones that have created a loyal following by delivering material that enriches the lives of their readers or viewers. And the fly-by surfers who arrive through search engines - and searchable headlines-generally leave as soon as they get the information they're after, usually never to return.

Even at the time, many observers were less than impressed with the portal strategy. As Jordan Worth, an analyst with International Data Corp. (Canada) Ltd., pointed out, portals don't deliver anything beyond a standard newspaper-style mix of news, business, entertainment and sports content-and editorial excellence is not very high on the list of priorities. "The kinds of things we're seeing in terms of application and content have not been terribly imaginative. That is just not where the battle is being fought" (McArthur, 2000). Similarly, in an article in 2001, Wayne MacPhail, a former director of content for Bell's Sympatico-Lycos, accused Canadian Web sites of serving "the equivalent of airplane food-neither offensive nor exciting to anyone."

Sometimes that desire for blandness blocks content that is not deemed appropriate for family viewing. That's certainly true of Bell Web properties, which appear to be targeted at the mythical Cleaver family despite being in media competition with The Simpsons and Sex and the City. And, in some cases, the desire for blandness censors legitimate voices on the political spectrum. ... Last October, when I was the shortlived director of content for Sympatico-Lycos I launched a feature called "InSite," six columnists from across Canada - all with fresh, lively voices I wanted Canadians to hear. I was forced to kill those 
columns because my superiors, none of whom had any journalism experience, felt that a couple of the writers were too left-wing (2001).

Anyone looking for hard news on any of the service-provider or browser portals today will find that little has changed since McPhail wrote those words. A typical day might bring a survey of bad celebrity fashion sense, the 10 scariest cars to drive, or the five foods you should never eat (portals love list stories), and very little of substance. It would appear that "news you can use" is alive and well on the Internet. On the other hand, newspaper Web sites, as we'll see in Chapter 5, have evolved to do pretty much what newspapers always have: some do dazzling and surprising work online, others offer only a surprising predictability and lack of imagination. As we'll see in Chapter 4, more people than ever are reading newspapers-and fewer people than ever are paying for them. So, the circulation problem has been solved, in a way, by giving the product away online and allowing aggregators to cull the best of what you have, sending droves of fly-by readers to the newspaper sites. What have not been solved are the questions of how to turn a profit from the Web and how to rejuvenate the more profitable print editions. At least from the point of view of the craftspeople in the business, the questions also linger of how to address that perceived slide in quality, how to return the dailies to being "my paper," and how to fund quality journalism when the audience appears still to be turning away from print and has become notoriously resistant to paying for news online.

THE MOST popular villain in most late-20th early 21 st century news-media criticism is economics. Publishers, producers, news directors and proprietors have long 
recognized the need to offer readers and viewers more than the facts one can get in an instant on all-day television or an aggregation site, but are loath or unable to spend very much money on it. Pundits and columnists are cheap; investigative reporters and feature writers are expensive. According to a survey of 105 unionized newspapers performed by the Newspaper Guild (2006) just before the recession, a top reporter's salary can range from $\$ 419$ to $\$ 1,626$ per week. ${ }^{2}$ The median salary is $\$ 900$. At the same papers, starting salaries range from $\$ 304$ weekly to $\$ 1,597$, with a median of $\$ 582$. Taking those two figures and averaging them gives us an overall median of $\$ 741$ a week, not including benefits. In a week, a publisher can use this money to produce roughly three to five columns, 15 to 20 telephone-reported or press-release-based stories, or one or two well researched investigative stories. To editors and publishers who want to deliver cheap content to a dwindling readership - and for chain owners carrying enormous debts, and shareholders expecting a return on their investment - the answer is simple: keep the salaries low and the copy-output high. In the same way, allnews television and talk radio are faced with the quite frightening task of filling 24 hours a day, seven days a week. But there often isn't enough news to fill 168 hours of television multiplied by the three main news networks in the United States and the three in Canada-a staggering 1,008 hours of combined airtime every week.

To fill all this air and paper, there has been an explosion in panels and pundits: analysts, commentators and experts called in to chew over every story that goes to air or print. McNair describes this explosion in opinion as one of the greatest threats to the credibility of modern journalism.

\footnotetext{
${ }^{2}$ All amounts are in US dollars.
} 
[O]ne important aspect of the crisis of public communication is said to be the ascendancy of subjective journalistic interpretation over objective fact-reporting. The normative functions of political news are being undermined by a proliferating commentary industry; a plethora of pundits who, drawing their cultural power from the privileged status of the journalist as licensed truth-teller, increasingly flood the public sphere with speculation and conjecture $(2000,61)$.

Meanwhile, Norris (1997) points out that increased competition from 24-hour TV news is one of the things that have put pressure on newspapers and networks to sensationalize and trivialize, or "tabloidize" the news - and that one of the manifestations of this is "speculation and conjecture" (2000: 70-73). The results of these economic and competitive pressures are newspapers that are more and more filled with wire stories, rewritten press releases, news stories generated by telephone reporting, and columns, fluff and opinion pieces masquerading as news. Often, the journalism ends up as a blend of old-fashioned essays and columns presented as factsin-the-making. ${ }^{3}$

Norris reports that most U.S. journalists complain that the press "pays too little attention to complex issues, blurs the distinction between reporting and commentary, is out of touch with the public and is too cynical" (ibid:: 311 ). She quotes two senior U.S. industry observers as saying a large majority of journalists feel the news culture has been degraded "from one that was steeped in verification and a steadfast respect for the facts, towards one that favours argument, opinion-mongering, haste and infotainment" (ibid.).

Meanwhile, Didion has famously accused journalists of alienating and boring their audience by turning politics into a game of "Insider Baseball," operating at a

\footnotetext{
${ }^{3}$ It would make a very interesting exercise to count all the newspaper headlines in a given day that contain the modal verbs "could," "would," "might" or "may."
} 
great remove from "the actual life of the country" (2006a: 744). Journalists, she complains, focus tightly on the polls and practices, the process of getting elected, and create a narrative "made up of ... tacit agreements, small and large, to overlook the observable in the interest of obtaining a dramatic storyline" (ibid.).

It is understood that this invented narrative will turn on certain familiar elements. There is the continuing storyline of the "horse race," the reliable daily drama of one candidate falling behind as another pulls ahead. There is the surprise of the new poll, the drama of the one-one colloquy on the midnight plane, a plot line (the nation sleeps while the candidate and his confidant hammer out its fate) ... (ibid.: 755).

THERE HAS been evidence that many news consumers have rejected the punditry, or have come to ignore it. Norris's intensive study of the 1997 British election indicated that "all the acres of newsprint which editorial writers devoted to trying to raise voters' concerns had no effect whatever" on the outcome of the election (Norris et al, 1997: 184). Despite editorial writers' and pundits' argument that Britain's relationship with Europe was the decisive issue, the public chose to focus on domestic policiessomething that supports the criticism that the British news media were operating at too far a remove from their readers and viewers. In fact, Norris and her colleagues found no evidence that the press or television news were able to set the public agenda. However, their research showed that the Conservative slide was fuelled largely by media reporting on sex scandals and incompetence, and the Liberal-Democrats' boost in support was propelled by their coherent platform and the fact that they stayed consistently on message. In other words, punditry did not influence the voters; reporting did.

There also is evidence that a large segment of the public also is repelled by the 
trivialization of the news. The U.S. Project for Excellence in Journalism has reported that "since the early 1980s, the public has come to view the news media as less professional, less accurate, less caring, less moral and more inclined to cover up rather than correct mistakes" (2007). Similarly, in a study of 3,012 Canadians, 80 per cent of respondents said they believed reporters' biases influence news; 54 per cent said they thought the news media tried to cover up their mistakes; one in three said they doubted the accuracy of news reports; 79 per cent said the news was often or sometimes unfair or not balanced; 92 per cent accused the news media of being at least sometimes sensational (CMRC, 2004).

There was speculation among observers and in the business itself that the events of Sept. 11, 2001, would return the news media to more sober, serious, issuesoriented reporting-rebounding from what many observers identified as a low point with the coverage of the Bill Clinton-Monica Lewinsky scandal of 1998. Yet, a year and a half after the World Trade Center attacks, Canadian Press was reporting that 62 percent of the respondents to a Leger Marketing survey found "their media were sensationalistic and biased." In the same survey, television news was rated the most credible source of information by 40 percent of respondents, followed by newspapers at 30 percent (Wyatt, 2002). And there was the issue of financial coverage. A more serious U.S. press had begun to pay attention to foreign affairs. Yet it still, for the most part, allowed its business sections to ignore the WorldCom and Enron scandals, and completely miss the high-risk mortgage storm that was drawing the world toward recession. "The securities fraud case of homemaking media maven Martha Stewart affected far fewer Americans than [Enron or WorldCom], yet drew more media 
attention, undoubtedly because of the celebrity aspects involved in her case" (McPherson, 2006: 182).

Yet, significant segments of the news media believe that the public wants more sensationalism and trivia, not less. Another Project for Excellence in Journalism study showed that, between Feb. 8 and March 2, 2007, coverage of the death of actress and nude model Anna Nicole Simpson consumed 15 per cent of CNN's news air time, 21 per cent of MSNBC's news time and 32 per cent of the "news hole" on Fox Newscompared to 17 per cent, 26 per cent, and 10 per cent respectively, for the Iraq War (2007a). So the press tends to fetishize power politics as hard news and trivialize as soft news most other forms of human endeavour. Yet, there is a world of things that people take very seriously and that the press treats as the lighter side of the news: culture (which becomes celebrity coverage), science and medicine (lifestyle and health), human relationships (advice and self-help), spirituality (the Sunday church pages).

SCHUDSON defines the news as a product manufactured with the intent of involving the public in a discourse about subjects that are "publicly important" (2003: 1-12). He quotes media scholar John Hartley: that news is "sense-making practice of modernity ... the most important textual system in the world" (ibid.: 12).

[The news] builds expectations of a common, shared world; promotes an emphasis on and a positive valuation of the new; endorses a historical mentality ... and encourages a progressive rather than a cyclical or recursive sense of time. The novel, as literary scholar Ian Watt pointed out, has a very similar resonance, and it is significant that it emerged as a prominent element in the cultural landscape of Europe and colonial North America at the same time the newspaper did-in the 18th century (ibid.). 
As we have seen from much of this criticism, often the response to crisis in journalism is to take economic, technological or cosmetic measures, or to ask the audience members what they wanted yesterday. Little emphasis is put on being better at telling us the stories we need "in order to live"-perhaps because this is a slow process and almost impossible to measure objectively in terms of progress or effect. Dewey argues that the public is waiting to be called into existence by "a kind of knowledge and insight which does not yet exist" (1954:166). If they want to create "an organized and articulate Public," he urges, the press must learn to think like artists (ibid.: 183).

Artists have always been the real purveyors of news, for it is not the outward happening in itself which is new, but the kindling by it of emotion, perception and appreciation. ... The highest and most difficult kind of inquiry and a subtle, delicate, vivid and responsive art of communication must take possession of the physical machinery and circulation and breathe life into it (ibid.).

Though they disagree on the so-called Lippmann-Dewey debate, Carey (1997c) and Schudson (1967) agree that journalism has turned away from politics and civic institutions, and become "the independent voter writ large" (Carey, 1997c: 245). Carey decries Lippmann's "antipublic and antipopulist" attitudes-raising the question of why public and populism must be connected - and argues that a press that acts as a watchdog and whistle blower turns members of the public from subjects to objects, and transforms "freedom of speech" into "freedom of the press" (ibid.: 247).

Yet, as we have seen, in Liberty and the News, Public Opinion and The Phantom Public, Lippmann anticipated much of the media criticism of the 20th and early 21 st centuries. He complained that journalism was imprecise, transient and often 
trivial, when what it should aim to be is "a servant and guardian of institutions" (1997: 229). Schudson (2008) points out that even Lippmann tended to over-simplify in his criticism. The major flaw in his thinking was that he believed having better educated journalists would solve all the problems of the news media, and he paid "too little attention to ways the state and the market distort the production of news" (ibid.: 1040).

Still, despite his reverence for the institutions of power, Lippmann anticipates Williams's denunciation of the "cheapjack" and the chorus of concern from the left that the corporate media uses its power to advance causes with which it is friendly, and, as Hallin argues, is a force for stasis, rather than dynamism. In the same passage cited above, Lippmann warns that "at its worst, [the press] is a means by which a few exploit disorganization to their own ends" (1997: 229).

Carey (1997c) argues that Lippmann's view of democracy is sterile and elitist-in his rejection of the omnicompetent citizen and his call for experts to advise and guide those we elect to govern us. When Carey charges that Public Opinion is the founding book of modern journalism, he argues that Lippmann's perspective and the contradictions in his thinking have been handed down to a modern journalism that professes to despise tyranny while displaying a profound distrust of democracy, and caters to authority and celebrity but disdains ordinary people. That is not so different from the charges of elitism and aloofness that have been aimed at the mainstream media by the emerging voices of the Internet—or that were hurled at the "straight press" by the underground newspapers of the 1960s and '70s.

As always, we return to the question of how to reconcile the two positions that Dewey and Lippmann have come to embody - or whether reconciliation is possible. 
The debate that has been fashioned around Lippmann and Dewey lives on in the perceived stresses between the mainstream media and the Internet. Alterman argues that mainstream journalism operates "on the basis of a Lippmann-like reverence for inside knowledge and contempt for those who lack it" while the Internet, represents "a Deweyan community trying to seize the reins of democratic authority and information from a Lippmann-like elite" (2008a). One supposes that Alterman isn't including in his definition of the Internet the thousands of newspaper Web sites - which are the predominant sources of news online, and the main suppliers of information to the aggregators and bloggers.

In this chapter, I have attempted to outline some of the stress points and fractures that have developed over roughly a century of declining circulation, financial fortunes and public respect for the press. Arguably, at the centre of the discussion are the works of Walter Lippmann and John Dewey. And the discourse revolves around the stresses created by finances and corporate structure, and the various attempts to impose social responsibility on the press-hinging on the irreconcilable problem that by setting standards or imposing controls, one risks killing the thing one has set out to protect.

THE NEXT chapter tracks the economic implosion of the North American media businesses that took place after the recession of 2008: the suddenly "broken business model," the mass layoffs and the threat that the news business as it has been defined up until now may be on the verge of extinction. 


\section{Dialectic of gloom: business}

IN THE LAST four years, it has begun to look as if the newspaper industry were sinking from the head and taking all passengers with it, and the rhetoric of the coverage has reflected this. Scan the headlines for the period and you see such recurring verbs as "slash," "cut," "plunge," “save," "survive," "shrink," “fall," "freefall," “decline," "tumble," "plummet," "slump" and-a new one for this industry - "outsource." In much of the discourse, "the language of the obituary" has crept in (PEJ, 2009) and the fear has begun to feed on itself, to the point that even positive news comes shrouded in gloom. A content study by Chyi, Lewis \& Zheng looks at how three newspapers covered the crisis: the Wall Street Journal, New York Times and USA Today. The three scholars came up with these four key findings:

First, with regard to media economics data, the coverage overwhelmingly focused on short-term changes (e.g., dramatic yearover-year declines) rather than providing a more historical perspective. Secondly, little contextual data were featured in the coverage, particularly in relation to the state of newspapers around the world and the recession-related struggles of other US industries. Thirdly, sourcing patterns privileged the views of newspaper management over external research or readers by a wide margin. In addition, when attributing the cause of the crisis, the coverage assigned blame to advertisers, readers, the Internet but not newspaper themselves. Finally, the overall tone of the coverage was largely negative, with more than a quarter of all stories including some "death" imagery $(2011,316)$.

It's not difficult to find evidence that the hysteria has distorted the discourse, 
and that, as those authors point out, despite the constant cuts to their product and the obsessive negativity of their self coverage, newspaper companies have been reluctant to consider the possibility that they may be their own worst enemies.

Quarter after quarter, small newspapers have reported profits, as have many newspapers that were being dragged down by the debts accrued by their parent companies. Though advertising lineage has been creeping downward and has not been replaced by online revenues, circulation has been exploding online and, in many cases, holding its own in print. Also, one wonders at the enthusiasm with which the press has been writing its own obituary, and questions the wisdom of screaming "Fire!" in front of a theatre to which you are trying to sell tickets. Dallas Morning News publisher James W. Moroney III put it this way in a letter to staff:

I don't know how the death of newspapers could have been any more exaggerated, especially in stories we in the newspaper business wrote about our own industry ... [W] gave it all we've got. And we did a great job. Everyone bought into the imminent death of newspapers. We managed to convince consumers, sell the notion to advertisers and scare away investors. It's enough to make you wonder why we were writing that newspapers were no longer an effective way to communicate (2010).

Even in its more positive manifestations, there is a tone of desperation and absolutism to the discussion. It's as if an entire industry decided that the gods had turned against it and the only way to salvation was to have a bonfire of the vanities and walk naked, innocent and penniless into the new world. Many of the prophets of the digital age - even the ones who want to preserve journalism - seem to be as keen on killing the print medium as they are on giving birth to a digital one. There are those who argue that non-profit, or limited profit Web sites such as Propublica are the answer to preserving a free press that will safeguard democracy. Others envision a 
world in which reporters carry cameras, microphones and smart phones and tweet, tape and write their stories for all media. Some publishers see a future in which the readers vote on the news, write it themselves and buy back their own workeliminating the need not just for ink, paper and delivery people, but for writers, photographers and editors, as well. And there are those on the other side, who can't imagine "newspaper" without "daily."

THIS CHAPTER and the two that follow survey the reporting and commentary that have taken place over the past four or five years of the so-called crisis in the news media, specifically in the newspaper industry. In the realm of business, the discourse mainly involves the mantra, "broken business model," and a lot of doom prophecy, anguish and reflection on the industry's dependence on advertising to finance the practice of journalism. Much of the conversation revolves around a given: If the newspaper business dies, so goes journalism, and this would be a disaster for democracy. Much of it also centres on a management storyline that strikes me as being rather self-serving: that the Internet has broken the newspaper business model and is forcing owners and publishers to cut back on journalism to keep down the weight of costs, so the ship can stay afloat. As we have seen in the previous chapters, there were a lot of problems with the way newspaper companies did business before the Internet-and there is little evidence emptying newsrooms will fix things.

One thing that colours much of the discussion is an uncompromising technological determinism that predicts a Utopian online society peopled by pure-hearted citizen journalists, with unlimited time and funding, acting tirelessly for the good of society, or 
big media companies colonizing and plundering the Web. Commentators such as Shirkey, McChesney, Alterman, Schudson and Rosen have weighed in with everything from dire predictions to prescriptions for renewal, to Internet evangelism, as have many reporters, analysts, business writers, bloggers, media critics and casual observers in the popular press and online. Some have tried to provide a nuanced ongoing examination of the situation and the discussion surrounding it. Some have jumped in looking for the simplistic and the high-concept and then jumped out, or fastened onto a narrative and stayed with it. Some have had the slightly hysterical don't-say-we-didn't-warn-you tone of the vested interest. (For example, without a note of irony, a CBC News: Sunday item in March 2009 went so far as to announce "The End of News.") As blogger Paul Dailing complains, the situation has given birth to a cottage industry of death-of-newspaper Cassandras:

The point's not to fix anything. It's to describe the problem more dramatically than the next guy. If Steve Outing says newspapers have a "death spiral" and Clay Shirky predicts a "bloodbath," the point goes to Shirky. Basically, I imagine a group of people watching a building burn down and bickering amongst themselves about whether it's a conflagration or an inferno. It's like that, but with consulting fees (2009).

Following the discussion can be a disorienting and bipolar experience, and disheartening as much for the peculiar enthusiasm of some of the end-times prophets as for the information itself. On one hand, we have had a sort of reflexive chanting of "information wants to be free" that neglects to reference the rest of Stewart Brand's legendary statement:

Information also wants to be expensive. Information wants to be free because it has become so cheap to distribute, copy, and recombinetoo cheap to meter. It also wants to be expensive because it can be immeasurably valuable to the recipient. That tension will not go away (Cited in Tofel, 2012: 88). 
The way Brand's words are often taken out of context, they make him sound like a naïve hippie ideologue inviting people to help themselves to all the music, film and text they can cram onto their hard drives. Taken in whole, his comments are a compact assessment of the central problem of the Internet: that it is very good at taking from each according to his or her ability, but terrible when it comes to providing to each according to her or his need. Brand further elaborates the difficulty of monetizing intellectual property once everyone has access to it. He points out that quality is irrelevant, because a bad movie, book or phone call costs the same as a good one-until the source develops a reputation for quality, "because the consistency (reliability) of source makes value somewhat predictable" (ibid.). As Shafer points out, the idea that people will never pay for content has become a salient feature of "Web orthodoxy" (2009c). However, Brand's argument is supported by the fact that news organizations such as the Wall Street Journal, Thomson-Reuters, Bloomberg and the Financial Times consistently turn a profit online, because they have information investors need and a reputation for reliability, and the information they provide has a tangible, financial value. Similarly, services such as Consumer Reports and iTunes have had little trouble getting people to pay for content. The three criteria for success in a paid site, according to Shafer, are: "1) They are so amazing as to be irreplaceable.2) They are beautifully designed and executed and extremely easy to use. 3) They are stupendously authoritative" (ibid.).

ON THE other hand, we have old media companies that appear to be convinced the Web, or the smart phone or tablet, are saviour technologies that will wipe away past financial and professional blunders and return everything to business as usual. Leaving aside for a 
moment the debts accrued through decades of leveraged acquisitions and the dedication to serving shareholders over readers or advertisers, there are two Original Sins, to steal a term coined by newspaper analyst Alan Mutter (2009), that may have done more than anything to create this mess: newspapers' decision to give away their product, their only source of value (Mutter's original Original Sin); and the failure of the industry to compete with online services such as eBay, Craigslist and Kijiji, which drained away a large part of their advertising revenue.

In the first case, the assumption was that the Internet would work the way television does, that a large number of viewers would translate into big advertising revenues. However, as John Morton points out, that didn't work out. "Lots of people came, but lots of advertising didn't. Last year, only 10 percent of newspaper advertising revenue came from online - this after a 10-year effort" (2011). This is the case for two main reasons: newspapers did not foresee the online competition for ad dollars, or how the Internet would expand the ways in which advertisers could reach their clientele. On the Web, ads can be targeted through user groups, search-engine inquiries or tweets; goods can be sold directly to consumers through sites such as Amazon, or special-interest or brand sites; classifieds can be interactive, immediate and free (unless one upgrades to attract more eyeballs, which is where the sites make some of their profit); consumer information can be mined from social media sites; promotional pushes and contests on Facebook attract "likes," which attract views.

In this environment, newspaper ad space becomes discretionary and specialized. For example, in 2009, when Mercedes Benz introduced a new E-class sedan, it ran bold, 3D displays on the home pages of the New York Times, Washington Post and Wall Street 
Journal. The estimated cost was $\$ 100,000$ per site (Clifford, 2009a). However, the car company's strategy was to make a splash with the mainstream media and then immediately move to a cheaper, more focused campaign involving buying from networks: organizations that bundle ad space on Web sites, often selling it at a discount. So, rather than being the main, day-to-day buy for advertisers, newspaper Web sites have become "the patent-leather stilettos of the online world: they get used for special occasions, but other shoes get more daily wear" (ibid).

A third factor was one nobody could have predicted, that the Internet would redefine the value of advertising. Advertisers had always known instinctively that their ads and commercials were reaching as many consumers they didn't want as those they did, but there was no way to tell one group from the other. So, they continued to buy space in newspapers and magazines, and time on television, under the theory that total penetration was better than none. However, online, it became easy to monitor the reach of ads and, therefore, easy to target only consumers who were interested in the product. Advertisers began to see that state of affairs as normal. "IUlser behavior could be carefully tracked; offline it seemed suddenly much more knowable, as advertisers demanded quantification where once anecdotes had sufficed" (Tofel, 2012: 44). And the networks also purchase and discount unsold online ad space - the way travel sites sell discounted airplane seats and hotel roomsreturning a fraction of the value to the newspapers.

As New York Daily News publisher Mort Zuckerman told the House of Lords Select Committee on Communications, the Internet may have expanded the reach of newspapers immeasurably in terms of audience, but in terms of advertising revenue, it 
has substituted "pennies for dollars" (Lords, 2008: 121). For example, the New York Times has roughly 30 million online readers, and a print circulation of just 900,000 on weekdays. Yet it derives 80 percent of its profit from the print edition (Grueskin et al., 2011: 21). Furthermore, the "internet occupied 28 percent of Americans' time spent on media in 2009 , but generated only 13 percent of total advertising spending" (ibid.). In a column in the New Yorker, James Surowiecki argued that it used to be that, when companies fell into the kind of downward spiral in which newspaper businesses find themselves, it was because people had stopped buying their product or service. With newspapers, thanks to the Internet, people are actually using them more - "they've just stopped paying for them, a kind of backhanded compliment to their continued relevance."

The real problem for newspapers, in other words, isn't the Internet; it's us. We want access to everything, we want it now, and we want it for free. That's a consumer's dream, but eventually it's going to collide with reality: if newspapers' profits vanish, so will their product (2008).

One reason it's difficult to monetize the digital product through advertising is that online audiences are wide but not deep. For example, a recent analysis of traffic to the website of a mid-size U.S. newspaper revealed that hard-core "fans" of the site amounted to just 4.3 percent of visitors, and "regulars" another 3.1 percent. Yet, those two groups were responsible for 64.3 percent of the page views. Meanwhile, "flybys"-directed to the site by a search engine or aggregator-amounted to 75.3 percent of visitors, but only 19.7 percent of the page views (ibid:: 24). James Harding, editor of the Times of London, arguing for a paywall, allowed that charging an admission fee would drastically cut down on the 20 million visitors who go to the 
Times's Web site, but dismissed that loss as simply a matter of culling the "window shoppers," the fly-bys who land on a Web site by search engine, read a bit and then flit off to something else (Pfanner, 2010).

In other words, the online audience that publishers and advertisers care about is the same one that matters to the print edition: the readers who browse the front page, and then follow the headlines into the stories, and keep coming back for more. This would imply that search-engine optimization is at best a waste of time and at worst counter-productive. It also goes a long way towards bolstering the newspapers' complaint that aggregators such as the Huffington Post, Yahoo, Google and the Daily Beast are profiting at their expense. Aggregator sites have long argued that they help the newspapers' business by promoting their work through links to the original stories that they collect from the paper's Web sites. The statistics on fans and fly-bys suggest that aggregators steal revenue from newspapers by repurposing material the dailies paid to create, posting it online and sending waves of useless fly-bys to the original site. Meanwhile, the aggregators create the loyal audience the advertisers want, and they build it with material lifted for free from the companies that pay to manufacture it.

All of this has serious implications for the method of pricing online ads by CPM (cost per 1,000 page hits), rather than according to the nature and loyalty of core readership. It's as if print publications tried to include into their circulation the people who pick up the paper at the newsstand, read a headline or one story, and then put it back-or, perhaps more pointedly, it compares directly to 'junk circulation' derived from print copies dumped at airports and hotels. Yet, oddly, advertisers who 
are concerned about wasted exposure-and complain when those dumped copies are folded into circulation figures-are just catching up with the inefficiency of counting CPMs. As media analyst Matt Shanahan writes in his blog:

When people talk about the size of an audience, that's a sham.... The digital world has changed the revenue dynamics for publishers. In the print world, a publisher's shipment of physical media is the basis for revenue. In the digital world, consumption of media is the basis for everything. ... In other words, engagement is the unit of monetization' (cited in Grueskin et al, 2011: 25).

The "economics of attention" is what Richard Lanham (2006), calls it: an assessment of value that is measured in how much fame, for want of a better word, one can create. As the model for success in this new market, Lanham uses Andy Warhol, a painter, filmmaker, and marketing theorist whose one theme was fame, stretched across multiple platforms. Warhol reproduced fame with his Marilyn Monroe and Campbell's soup tin silk-screens; he mocked it as producer and director of movies that celebrated sleaze or sneered at the audience; he wallowed in it with Interview magazine; and he lived it, or behind a facade of it, with his life, his Factory and his entourage. Like so much that enters the current discourse, the Warhol example serves to strengthen the argument that the salient difference between the digital age and what came before is how much easier it is to be a trader in the economics of attention, and how much more difficult to turn a profit.

WHEN YOU add all of the above to the fact that most large newspaper companies trudged into the Great Recession of 2008 dragging huge debts behind them, its easy to see how it

${ }^{1}$ My italics 
all easily blended into a Doomsday narrative. Just at the moment the industry needed to be innovative and daring to meet the challenges of the digital age, most found themselves fighting a rear-guard action against their creditors.

[T] he company has borrowed a lot of money to make acquisitions ... and the company's newspapers, while still profitable, throw off lower profits during a recession. This can mean that a company encounters difficulty meeting debt obligations and meeting lenders' requirements for cash flow coverage of interest payments and the like. A company can respond by renegotiating its debt ... which raises the interest rate; by eliminating or cutting its dividend payments to shareholders ... and by unloading assets ... And, most common, a company can lay off employees, eliminate special features and sections, tighten news space and cut back circulation to reduce newsprint and distribution costs. Those actions, of course, diminish the standing of newspapers in their markets and to some extent undermine efforts to transfer strong brand names and advertising efforts to the Web. The long-term impact of these actions is yet to be learned, but it is unlikely to be beneficial (Morton, 2008).

There were early warnings that things were changing for newspapers' print and online operations. Right on the heels of the dot-com bust of 2000-which coincided with newspapers' most profitable year on record (Tofel, 2012: 9)-there was a steady drop in newspaper advertising. This was from 2001 (following the attacks on the World Trade Center) to 2003, and, when that short slump ended, advertisers didn't follow their usual pattern of returning to their old spending habits. For example, from 1950 to 1990 , newspaper advertising growth in the United States showed a constant rise, from $\$ 2$ billion to approximately $\$ 30$ billion, then a short drop in 1990 , followed by another constant rise, to $\$ 47.4$ billion in 2000 , then another drop, to approximately $\$ 40$ billion. This time, however, instead of an incline, the chart shows a plateau to 2005 , the year advertising revenues began a slump from which they have not recovered (Picard, 2008: 708). Robert Picard explains that 
advertising revenues "typically rose higher than GDP growth in good times and fell further than GDP declines during recessions and downturns ..." However, "advertising did not recover after the 2001 recession, as it had in the past" (ibid.).

Then, with the crash of 2008, the floor disappeared: between 2005 and 2009, U.S. advertising revenue plunged 44.2 percent -and 27.2 percent in 2009 alone (Pérez-Peña, 2010a). What really unnerved newspaper owners and publishers was that online advertising revenue stopped rising, and then began to fall, too. The new income stream upon which they had been banking was drying up with the old one. For example, in 2009, online ad revenue fell 11.8 percent (ibid.). At the time, the expectation was that newspapers had bottomed out, and things would get better in 2010. However, by 2011 , industry-wide profit margins in the United States had fallen by 50 percent over what they had been in 2001: from 28.3 percent to 14.9 percent (Shaw, 2012). "[E]ven though advertising has recovered in magazines, on radio and on TV - where it had weakened during the recession-it never came back for newspapers. In fact, it keeps going down" (Mutter, 2011).

Strangely, much of the reporting and commentary, especially in the popular press, reacted to these statistics as if they were the result of some sudden, unforeseen extranatural catastrophe - as if a giant, radioactive lizard had stomped out of the sea and through their industry, and they were the terrified villagers. However, as with Godzilla, the business conditions that created this "perfect storm"-perhaps the single most overused media metaphor of the period-were neither unforeseen nor unnatural. As we saw in Chapters 2 and 3, in the 1990s, a considerable amount of advertising had begun to look for new outlets: "such household names as Procter and Gamble, McDonald's, Seagram's, 
Ford Motor Company, Coca-Cola, Nissan, Kodak and Campbell's Soup ... are saying something scary to publishers: 'You're not worth our money' "(Miller, 1998: 11).

As for classified advertising, it has all but disappeared. Big-city dailies that once printed entire sections of classifieds now run two or three pages of the announcements that once contributed much of their profits, and have late-coming online ventures that are alsorans to Kijiji and Craigslist. Downie \& Schudson (2009) point out that, as television began to drain away display advertising from newspapers through the 1960 s and ' 70 s, newspapers became more dependent on classifieds, which the electronic medium couldn't do. However, the Internet can do classifieds-much better, in fact, than print newspapers. Classified ads truly are a community talking to itself and, as such, they're more efficient and more attractive when they can change and be updated by the minute, and when the viewer can achieve instant gratification from clicking on a link or sending an email. For example, the way Craigslist and Kijiji display the time an ad was posted-a day, an hour or a minute ago-gives the viewer a sense of being actively involved in a hunt, much the way eBay does with its bidding system. In comparison, by the time a reader gets to a newspaper classified ad, it isn't just dead; it's decomposing. And someone with something to sell can place an ad for free online, while they have to pay for newspaper space.

One legend of the Web is that Craig Newmark pitched his idea for online classifieds to his hometown newspaper, the San Francisco Chronicle and, "only after being summarily rejected did he go on to found Craigslist and singlehandedly decimate the primary revenue source of newspapers everywhere" (Rubenstein et al., 2012). Some might say there's a poetic symmetry to the fact that, in 2009 , the Chronicle came close to being the first big American daily in a single-paper city to fold, as its owner, the Hearst 
Corp., threatened to close it if it couldn't be sold (Liedtke, 2009a), only to give the paper a reprieve and relaunch it with glossy cover pages a few months later (Liedtke, 2009d). So, the "received wisdom is that newspapers succumbed to a stealth attack from Craigslist" (Tofel, 2012: 71-72). In reality, however, newspapers across North America were experimenting with classifieds at around the same time Newmark founded his email notice board, which evolved into what we know today. In Canada, Sun Media, the Globe and Mail and Toronto Star, for example, all had successful automobile-sales and career sites running long before Craigslist became a household word and, in the United States, a consortium of six newspapers, including the Chicago Tribune, also beat Newmark to the Web, "but failed to compete effectively with a single geek working out of his apartment" (ibid: 72).

In Britain the situation was not much different. In 2007, before the full effects of the recession hit, executives from The Guardian told the House of Lords Select Committee on Communications that classifieds were slipping away at a rate of 10 percent per year. Representatives from The Times of London told the committee that "the most dramatic difference for the business model over the past 10 years had been the 'decline of classified advertising' " (Lords, 2008, 16). Back in the United States, in one decade starting in 1999 , classifieds fell from 40 percent to 20 percent of all newspaper advertising (McChesney \& Nichols 2010: 27), dropping 42 percent in 2009 alone. At that rate, "classified advertising will barely exist for newspapers by 2012" (ibid.: 28). Anyone who has picked up a daily newspaper recently will attest to the accuracy of that prediction.

SINCE 2005, and accelerating with the Great Recession of 2008 , the big media companies 
have faced almost nothing but shrinking revenues, and this has greatly exacerbated the strain caused by the debts they carried into this crisis. The financial troubles of those large media companies have contributed greatly to a downward spiral in the fortunes of most North American big-city daily newspapers, as heavily indebted media companies have slashed newsroom budgets in response to the unprecedented slide in classifieds and display advertising, which by mid-2011 had accounted for 20 consecutive quarters of declining advertising across the industry, representing a plunge of 48 percent in revenues (Kaplan, 2011). The loss was so severe in the big dailies that money earned through circulation - which in some chains was actually rising - began to catch up to advertising as a percentage of newspaper revenues (Chittum, 2009a). Traditionally, ad revenue has, on average, accounted for 80 percent of the dailies' earnings (Krashinsky, 2010b), but by mid-2009, the New York Times reported that its advertising-to-circulation ratio of profits had gone from two-to-one to one-to-one in just three years, (Chittum, 2009b). Circulation revenue was predicted to pass advertising for the first time in the paper's history in 2012 (Chittum, 2012a).

The mood in the industry quickly went from nervous to panicky, and the panic led to an unprecedented gutting of newsrooms. Poynter's Rick Edmonds estimates that between 2007 and 2009, the U.S. newspaper business reduced its spending on journalism by $\$ 1.6$ billion annually (2009). And, when it comes to replacing the investment newspapers make in journalism, it "would take roughly 1,600 [non-profit news sites] Minnposts or Voice of San Diegos to replace the spending on journalism that newspapers have cut" (ibid.). The American Society of News Editors recently announced that the level of staffing in American newspapers is at its lowest point since the group began taking an 
annual census in 1978. That is, U.S. dailies employ 40,600 editors and reporters, compared to a peak of 56,900 in 1990 . That's a decline of 28.6 percent (Mutter, 2012a).

In Canada overall, the income-to-debt situation (aside from Postmedia) is not as dire as at many of the large U.S. chains. However, as Kijiji and Craigslist operate in Canada as in the United States, the drop in classified advertising is comparable, as is the shrinkage in display advertising. Circulation remains problematic in most cases. For example, between 1995 and 2010, average daily circulation at the Globe and Mail actually rose by 0.9 percent, from 314,972 to 317,781 , while the paper's crosstown rivals-which do not have national editions - saw sales plunge. The Toronto Star lost 43.7 percent, from 519,070 to 292,003 and the Sun dropped 42.1 percent, from 250,695 to 145,252 . The situation is similar, to varying degrees, across the country, ranging from drops of 43.8 percent and 31.6 percent at the Edmonton Sun and Journal respectively, to 26.6 percent at the Ottawa Citizen and 11.8 percent at le Journal de Montreal. The only place were circulation loss has been minimal is at Montreal's Gazette, which dropped just 1.7 percent. This could be attributable to the fact that the Gazette is the only English paper in the city and also has extensive reach into the francophone and allophone population-people who speak a language other than French or English - and the immigrant community. The only significant increases have been of 9.8 percent at the Halifax Chronicle-Herald and 7.3 percent at the Calgary Herald (Newspapers Canada, 2010, cited in Dornan, 2012). As Christopher Dornan (2012) points out, the anomalous circulation increases in Calgary and Halifax are cases where the larger newspaper has benefited from the misfortunes of the smaller one. In Halifax, the rival Daily News, with a circulation of 20,000 , shut down in 2008 and the Herald's rival Calgary Sun has lost 28,798 circulation. So, though both the 
Herald and Chronicle-Herald showed circulation gains of 9,000, the number of newspapers sold actually dropped by almost 20,000 in Calgary and by 10,000 in Halifax (Dornan, 2012: 55). As at U.S. papers, online editions have picked up large readership but that has failed to translate into sufficient revenue to make up for the losses of the print editions. Though online advertising revenues in Canada for 2010 were $\$ 2.23$ billion, only $\$ 213$ million went to newspapers, less than 10 percent (ibid.: 62). As in the United States, Canadian newspapers were finding stiff competition for online advertising dollars.

In response to the situation, there has been a steady stream of layoff and buyout announcements from Canadian dailies. For example, the 13-year history of Quebecor's Sun Media ownership has been a constant trickle of layoffs and buyouts, peaking with 600 job cuts in 2008 and another 400 in 2012 (Globe and Mail, 2012). There were also two drawn-out labour disputes at the company's flagship newspapers in Quebec-15 months, in 2007-08 at le Journal de Québec (Gazette, 2008) and two years in 2009-2011 at le Journal de Montréal (Séguin, 2011). The latter resulted in a settlement of unprecedented harshness, which called for the rehiring of just 62 of the 227 workers who had been locked out by the company (ibid.). In the past year alone, Postmedia, which took over the Canwest newspapers in 2010, has slashed some $\$ 35$ million worth of jobs (Krashinsky, 201 1a), closed its national news syndicate (Globe and Mail 2012b), discontinued Sunday editions at its Ottawa, Edmonton and Calgary papers (Ladurantaye, 2012c), outsourced much of its newspaper editing and page production to a central newsroom in Hamilton, Ont., (ibid.) and sold off its Toronto headquarters, which also houses the newsroom of the National Post (Canadian Press, 2012). In July of 2012, the company posted a $\$ 12.1$ million loss in its second quarter, a drop of 6.1 percent over the previous year, and 
announced a three-year "cost transformation plan" to "reduce legacy newspaper infrastructure costs" (Financial Post, 2012a). In Late 2009, the Toronto Star announced the "biggest restructuring in the newspaper's history" (Friend, 2009), which ended with the elimination of 78 editing jobs, but backed away from a plan to outsource all its copy editing to an off-site production company (CBC.ca, 2010). Roughly two years later, Canada's largest newspaper announced another round of staff buyouts, and that, after all, it would outsource ad-building, layout and editing work to Pagemasters North America (Reuters, 2011). In Australia, the Fairfax chain has announced plans to eliminate 1,900 jobs and shut its main printing plants, and turn its largest dailies, the Sydney Morning Herald and Melbourne's The Age, into tabloids, in preparation for taking them completely online (Huxley, 2012).

It would take far too much space to produce a shopping list of all the layoffs by such companies as Gannett, Tribune, McClatchy and Hearst, as well as the smaller North American chains and collapsing community papers in the United Kingdom. However, the Paper Cuts blog has kept a running tally of layoffs and buyouts in the U.S. newspaper business that presents a fairly clear overview of the magnitude of the employment catastrophe that has befallen the industry. The worst year was 2008 , with 15,993 lost journalism positions in the United States. The total positions eliminated there between January 2007 and July 2012: 41,344 (newspaperlayoffs.com, 2012).

MOST OF the end-of-news discourse has taken the fortunes of these large, debt-ridden conglomerates and extrapolated from their condition a prognosis for the entire newspaper industry. In all things, the North American news media tend to focus on large, institutional 
North American subjects, and it has been the large institutional North American newspaper company that has suffered the most from the recession. So, the coverage tends to create an impression of a medium no one wants any more, and publications of no value that are bleeding money. "Ordinary troubles become inflated into 'crises' because crises sound somehow more dignified or electrifying" and, though a "problem" sounds manageable, a "crisis" has a dramatic ring of doom about it (Gitlin, 2009).

There's no doubt that there has been bumper crop of headlines involving plunging advertising, slumping circulation and plummeting share prices. Yet, even when the news is good, the language is dire: A story about the Wall Street Journal and New York Times posting 20 percent increases in ad sales comes with the headline "Publishers See End to Freefall ..." (Adams \& Ovide, 2010). Another, dealing with the prospect of advertising growth is called, "Bloodletting in U.S. Industry Slows ..." (A very, 2010). The tone is not that there is bad news and good news, but rather that there is impending bad news, pressing bad news, disastrous bad news, and slightly and temporarily receding bad news. Headline writers doing their jobs with the axe poised over their necks can be forgiven for having such a pessimistic outlook-especially coming off two years like 2008 , which saw the first sudden wave of increasing grim news, and 2009, which has gone down in the books as "the worst year the newspaper business has had in decades." In 2009, U.S. newspaper advertising revenue fell 27.2 percent from the awful 2008 , which was the previous record holder for worst year since the Depression (Pérez-Peña, 2010a). Things have not been improving. At the end of 2011 , newspaper company analyst Alan Mutter reported that 11 major U.S. newspaper companies had seen their stock value drop by an average of 27 percent (Shaw, 2012). Even Gannett, the company that wrote the handbook 
on how to please investors, watched its profits fall by 33 percent (Greenslade, 2012).

Yet individual daily newspapers, on the whole, remained profitable. For example, in the second-worst year, 2008, publicly reported U.S. newspaper companies had an average operating profit margin of 11.3 percent (Morton, 2008). Yet, as we saw, because of debt, it's possible for "a company that owns a collection of profitable newspapers to get into trouble during a recession" (ibid.). Two examples, one each in the United States and Canada, serve to explain how.

If there was a sonic boom in the accelerating financial dive of the big media companies, it was the December 2008 announcement by the giant Tribune Company that it had entered Chapter 11 bankruptcy protection. Tribune was something of a textbook case of a big media company that walked into the recession of 2008 with its eyes shut. An outgrowth of the Chicago Tribune and the product of a 2000 merger with Times Mirror, which owned, among other properties, the Los Angeles Times, Tribune counted among its possessions $50 \mathrm{Web}$ sites, $25 \mathrm{TV}$ stations and eight major newspapers. It also owned the Chicago Cubs baseball team and had real estate holdings that included the Cubs' home stadium, Wrigley Field, and the magnificent neo-Gothic Tribune Tower on Chicago's lakefront (Thornton \& Grover, 2008). Even though it had been slumping, this was a company accustomed to 25 percent profit margins (O'Shea, 2011:2).

The 2008 recession hit a year after Chicago real-estate mogul Sam Zell had pulled off a complicated buyout that involved employee participation and the acquisition of $\$ 8$ billion dollars in debt. This had been piled onto a large debt that the already struggling Tribune Company had been carrying - for a total of roughly $\$ 13$ billion. When the recession hit and the bottom dropped out of the advertising market, the company was 
caught with reduced revenue and crippling debt payments $-\$ 1.4$ billion in June 2008 alone (Thornton \& Grover, 2008).

Like all leveraged buyouts, the Tribune acquisition was supposed to have been financed by advertising profits, inflated by cost cutting. The company eliminated 2,500 jobs in one year, 16 percent of its work force (Greisling, 2008), and began to sell off assets, such as Long Island Newsday, which went to Cablevision for $\$ 632$ million. This went directly to servicing debt (Weisenthal, 2008). However, in December 2008 , after suffering a $\$ 124$ million loss in the third quarter of the year, and with $\$ 1$ billion in debt payments due, the company declared bankruptcy and sought Chapter 11 protection (Foley, 2008). At the time, Zell told the press that "factors beyond our control have created a perfect storm - a precipitous decline in revenue and a tough economy coupled with a credit crisis that makes it extremely difficult to support our debt" (Merced, 2008). However, he told the Los Angeles Times, the company had "a positive cash flow before debt service was taken into account" (Rainey \& Hiltzik, 2008). For example, the L.A. Times had projected a $\$ 100$ million profit for 2008 - down from $\$ 240$ million two years previous, but still well into the black (ibid.).

At the time, Geneva Overholser, director of the school of journalism at the University of Southern California, told the Chicago Tribune that the collapse of its parent company represented "the spectacular failure of an economic model of newspapering" (Greisling, 2008). As of September, 2012, the company had yet to emerge from Chapter 11.

Meanwhile, in Canada, another print and television giant was running into trouble 
servicing its debt. As we saw in Chapter 2, Canwest had purchased most of Conrad Black's newspaper holdings in the early 2000 s, operating under the standard belief that advertising revenue and cost cutting would produce a formula for paying off the debt, servicing shareholders and allowing the company to grow. Much of Canwest's debt was accrued with the purchase of the newspapers, for $\$ 3.5$ billion, which was exacerbated by the company's 2007 purchase for $\$ 2.7$ billion of Alliance-Atlantis Communications Inc.owner of a stable of cable channels, such as History Television, Showcase and Slice (Robertson, 2009a). Canwest's revenues had been rising year after year, from $\$ 2.9$ billion in 2007 , to $\$ 3.1$ billion in 2008 , but its share value had dropped from $\$ 20$ in 2000 to 60 cents in eight years (Hood, 2008). And the company was the most advertiser-dependent media firm in Canada, with 77 percent of its revenue coming from ads and commercials (ibid.). So, when the recession hit and companies cut advertising budgets, Canwest-like Tribune but on a smaller scale - found itself with a stable of less-profitable TV stations and newspapers, and not enough cash flow to service debt. Finally, in October 2009, a little less than a year after Tribune went under, Canwest asked for protection under the Companies' Creditor Arrangement Act, Canada's equivalent of Chapter 11.

Unlike Tribune - which appears to be a mess too large for anyone to deal withCanwest was sold off in fairly short order. In May 2010, the U.S. investment banks JPMorgan Chase \& Co. and Morgan Stanley provided $\$ 700$-million in loans to back unsecured creditors' purchase of the company's newspaper holdings for \$1.1-billion (Willis, Krashinsky \& Grant, 2010), placing former Sun Media CEO, and current president and CEO of the National Post Paul Godfrey in charge of the new company, called Postmedia, which announced that it would be a "digital first" publisher (Robertson 
\& Krashinsky, 2010). As one Toronto media buyer told Canadian Business magazine at the time, the shortage of details gave no comfort to investors and advertisers. "It's hard to get excited about Godfrey's vague new strategy" (Watson, 2010).

As of June 2012, Postmedia was carrying \$516 million in debt (Ladurantaye, 2012a). So, one failed leveraged buyout has led to another teetering one, although there had been an alternative. Several potential buyers and buyer-groups had popped up across Canada - including one that wanted the Ottawa Citizen, The National Post and The Gazette in Montreal, another that wanted the B.C. dailies, and a third that was interested in the Calgary Herald and Edmonton Journal. However, Canwest refused to consider a "piecemeal" sale, because the company needed to raise $\$ 935$ million to cover debt, and was afraid of falling short and being left with unsalable properties (Robertson, 2010). As for the company's TV holdings, Calgary based cable company Shaw Communications picked up the Global Television Network and all its specialty channels (Flavelle \& Spears, 2010).

For the most part, the remaining Canadian newspaper companies managed to struggle through the recession, cutting staff, reducing the size of their publications and outsourcing or centralizing some of their work. Across the United States, however, many companies were in much worse shape. In April 2008, Madison Wisconsin's Capital Times stopped printing and turned itself into an online publication (Cohen, 2008). A year later, the Hearst Corporation did the same with the 146-year-old Seattle Post-Intelligencer, slashing staff and turning it into an online community paper (Oppmann, 2009). In 2009, the Minneapolis Star-Tribune declared bankruptcy and went into Chapter 11 (Phelps, 2009). The same year, in Chicago, the Sun-Times joined the Tribune in bankruptcy 
(Roeder, 2009), and Denver's Rocky Mountain News folded (Adams, Ovid \& Simon, 2009). In 2010, Affiliated Media, owner of the Denver Post, Salt Lake Tribune and the San Jose Mercury, went into Chapter 11 (Tsai, 2010).

As we shall see in the next chapter, Apple's 2010 unveiling of the iPad saw a return to the saviour technology narrative. "The newspaper industry enters 2012 neither dying nor assured of a stable future. The industry has rallied around a story about itself that year-by year it is developing new digital products and new revenue streams to transition from dependence on print advertising" (PEJ, 2012). However, there doesn't seem to be very much relief in sight for the short run at least, as online gains fail to live up to expectations. As of 2011, print advertising was down $\$ .1$ billion and online was up \$207 million over the previous year. In other words, print losses were 10 times greater than online gains - down from the seven-to-one ratio of 2010 (ibid.).

THERE IS so much bad news that it becomes wearying and confusing just to keep track of it. Yet, the situation is more complex than the rush of Doomsday headlines would lead us to believe. For example, the Project for Excellence in Journalism in its 2011 year-end report paints a picture of an industry that is profitable but only marginally so. It is also one that has long been unable to improvise, innovate and experiment, but may finally be finding its way out of the wilderness.

Most U.S. dallies are profitable, even if debt and one-time charges (such as buyouts and layoffs) have made profit "razor thin." On the negative side, many are profitable because of cost cutting; and some have chosen to take a loss rather than cut quality. 
- Audiences are holding up, though they're not producing revenue. Print circulation continued to decline, while digital audiences grew. The problem is that no one can figure out how to put a reliable value on those audiences, so they can be sold to advertisers.

- Stock values are mostly still in a slump.

- U.S. newspapers began changing hands again late in the year, with perhaps the most promising sign being the emergence of some hometown buyers.

- As in Canada, newsrooms continued to shrink.

- The only print publications that showed growth in the United States, in terms of audience and profit, were the big Sunday newspapers, which now represent 33 percent to 50 percent of revenue at some papers. And some companies are considering abandoning daily publication in favour of select-day circulation.

- Again as in Canada, the industry finally began to implement strategies for drawing revenue from consumers, ranging from digital subscriptions to paywalls, to forming licensing organizations (PEJ, 2012).

Unfortunately, in Canada, we have no organization like the Project for Excellence in Journalism, but a survey of the business pages reveals a similar situation, without the rash of bankruptcies and newspaper closings that the United States has seen over the past four years. Without question the biggest developments took place in 2010: the breakup of Canwest, and the acquisition of CTV and its broadcast properties by BCE Inc.-involving the return of control of the Globe and Mail to the Thomson family's Woodbridge Co. In the first instance, this meant major daily newspapers in Vancouver, Calgary, Edmonton, Saskatoon, Regina, Windsor, 
Ottawa and Montreal, and the National Post were into their third owner, and second leveraged buyout, in a little more than 10 years - a company trying to implement a digital-first strategy, while being forced to constantly fight costs. As of fall 2011 , digital sales accounted for only eight percent of the company's total revenue (McNish \& Krashinsky, 2011). In the case of the Globe and Mail, the newspaper was returned to the Thomson family, which had owned it from 1981, when it acquired the old F.P. Publications, to 2001, when BCE originally acquired it along with CTV. The story of the BCE company between then and now is an extremely convoluted tale of changing strategies on the part of $\mathrm{BCE}$, and the coming and going of minority investors, including Torstar, the parent company of the Toronto Star, and the Ontario Teacher's Pension Fun. In the end, BCE returned to its original vision of a blended delivery and content company, buying up CTV and all its specialty stations and spinning off the Globe and Mail to Woodbridge, owner of the Thomson-Reuters news service.

In the end, almost all of English Canada's private television stations and networks were in the hands of three delivery companies, BCE, owners of Bell telephone, Internet and satellite services, and the Rogers and Shaw cable companies (Marlow, 2010). The Globe, however, had become a single-paper entity. By divesting itself of its stake in CTV and increasing its percentage of the Globe and Mail to 85 percent, Thomson had placed a powerful vote of confidence in the paper, and its future. In an editorial heralding the deal, Globe editors quoted the company's founder, Toronto-born Roy Thomson, Lord Thomson of Fleet: "We believe a newspaper should be financially sound to be healthy ... sometimes it isn't necessary to publish a good newspaper to make money-but it is necessary to make money to 
publish a good newspaper." The editorial went on to say, perhaps somewhat smugly, that "economic cycles come and go. Social fads can emerge and fade. Even technological revolutions can take their toll. But strong principles, they endure" (Globe and Mail, 2010).

So, even in the gloom of big-city dailies, there were scattered rays of sunlight, such as the Globe going into the future with an owner who believes in newspapers, and circulation rising or holding its own in the United States with the big Sunday editions, arguably the most important ones of the week in terms of the public discourse.

However, if one looks away from the chains, and the big North American metro papers, to include smaller papers and foreign markets in the formula, the picture becomes, if not bright, certainly a lot less grim, and a great deal more complex.

IN LATE 2011, billionaire investor Warren Buffett sent a ripple through the newspaper business by purchasing his hometown newspaper, the Omaha World Herald. Buffett wasn't new to the business; he had owned the Buffalo News since 1977 and, through his investment firm, Berkshire Hathaway, held a "substantial minority interest" in the Washington Post and a seat on the Post's board (Wemple, 2012). Yet, less than two years earlier, Buffett had told the Wall Street Journal: "For most newspapers in the United States, we would not buy them at any price. They have the possibility of going to just unending losses" (2009). The reason, he went on to say, was that newspapers had ceased to be essential to readers and, therefore, to 
advertisers.

In some quarters, Buffett's purchase was written of as a sentimental bid to keep the hometown paper alive. But then, in May, 2012, Berkshire Hathaway paid $\$ 142$ million to Media General to buy 62 small dailies in the U.S. southeast, forming a subsidiary, BH Media Group, to run its newspaper holdings (Segar, 2012). Shortly after taking over the World Herald, Buffett had made it clear that he was not acting out of sentimentality. He told shareholders in Omaha that newspapers have "a decent future" if they solve at least one of the "three big problems they face": the fact that they have lost the monopoly on information that made them an essential service; they have an extremely high-cost form of manufacturing and distribution; they give away for free what they spend a fortune producing (Bundy, 2011). "So far, I would say the evidence is there will be many papers who can deal with these problems.... The great majority of newspapers are making money" (ibid.). Specifically, Buffett was talking about small-market newspapers. "In towns and cities where there is a strong sense of community," he said, "there is no more important institution than the local paper" (Roberts, 2012). Media observer Jack Shafer took perhaps the least charitable view of Buffett's purchases, saying that it was as if "an old cow that's still a milker has been moved to a neighboring farm's pasture, where it will be squeezed until it can give no more and will then be ground into pet food" (2012a). Still, he continued, the purchase of the 62 papers - and the titles Buffett chose to buy - was an indication of the continued value of small, local newspapers.

Aside from Richmond, Va., and Winston-Salem, N.C., most of the towns where Buffett is now the press lord are backwaters - places like Hickory, N.C., Bristol, Va., and Eufaula, Ala. These small dailies and weeklies still retain franchise status because they cover local issues 
nobody else does, and they make money. It's worth noting that Buffett did not purchase Media General's Tampa Tribune, an unprofitable paper in competition with the Tampa Bay Times (née St.Petersburg Times) with no franchise value on the horizon (ibid.).

This highlights the fact that, while the narrative of the failing large-market North American newspaper had dominated the discourse, there were several less-told stories of areas in which the business is surviving and in some cases thriving - and that print is not necessarily dead.

Even among the large papers, there have been glimmers of good news. For example, in 2009, New York Daily News owner Mort Zuckerman invested \$200 million on new presses that allow the paper to be printed entirely in colour (WAN, 2009). A year later, the Globe and Mail committed $\$ 2$ billion over 18 years to new printing presses. Though the Globe is a leader with online and other digital publishing, the paper's publisher announced that print "is where the future of newspapers is" (Austen, 2010). In the cases of both the Daily News and the Globe and Mail, the publishers said they were upgrading mainly to attract high-end advertisers. Interestingly, media buyer and news business analyst Ken Doctor endorsed the long-term commitment to print, which he describes as "a niche for an older, monied demographic" (Watson, 2010). In November 2010, the Atlantic Monthly - which considers itself a "digital-first" company - announced the highestearning issue in its history, and one that represented a 95 percent gain in ad revenue over November 2009 (Kinsman, 2010). In August 2011 , the New York Times repaid a $\$ 250$ million loan to Mexican billionaire, and minority Times Company shareholder Carlos Slim Helú, 31/2 years ahead of schedule (Peters, 2011a). The company had borrowed the money to see it through the "worst year" of 2009. In 2011 , the Toronto 
Star reported that its earnings were up $\$ 65$ million over 2010 (Yew, 2012). Though it later resorted to job cuts, the Dallas Morning News in 2009 announced it was raising its cover price, hiring staff and experimenting with a "premium product" approach to reduce dependency on ad revenue (Bailly, 2009). The Economist and Financial Times - both British publications with a world reach-consistently reported profits through the recession by delivering high-quality, premium content online and in print (Fell, 2009; Flamm, 2010). Though it did experience layoffs, the Winnipeg Free Press-Canada's largest independent daily ${ }^{2}$ - was able to maintain positions such as movie critic, TV columnist and Ottawa correspondent, which chains had long since centralized (Cornies, 2009). Though the Free Press suffered along with the rest of the industry, it still reported net earnings of $\$ 10.7$ million for the last quarter of $2011-$ down slightly from 11.1 million in the same period of 2010. Digital operations, meanwhile, grew by 17 percent over the same year (Winnipeg Free Press, 2011). In March 2009, Seattle was a city in danger of becoming a no-newspaper town, with the Post-Intelligencer gone web-only and the Times "holding on by our fingertips," according to the paper's publisher, Frank Blethen (Johnson, 2009). By August, the New York Times was heralding the Times as "resurgent as a solo act." The paper, an independent owned by the Blethen family, had begun to operate in the black and its daily circulation had risen 30 percent (Pérez-Peña, 2009). In the previous year, the paper had cut some 165 editorial staff, and that combined with increased revenue owing to lack of competition and being released from its Joint Operating Agreement with the $P-I$ had pushed the Times into the black. It also helped that it was an

\footnotetext{
${ }^{2}$ Technically, it is part of chain, its owner, F.P. Publications, also owns the nearby Brandon, Man. Sun.
} 
independent daily with an ownership, the Blethen family, willing to carry it through the bad times (ibid.), and proud not to be a party to the "inexorable, greed-fueled feast" of the highly leveraged, publicly-traded corporations (Blethen, 2009). One thing all of these corporations have in common - as Blethen so colourfully pointed out - is that they're not owned by large, heavily indebted media conglomerates, and they entered the recession in stable financial shape. By having further to fall and being under the stewardship of owners with a strong commitment to their survival, they mostly rode out the slump in better shape than papers owned by big media companies.

However, it's in the smaller communities in the United States and Canada that dailies and community papers have been more than holding their own. Being the sole source of news in their communities has not only slowed their decline, but also bought more time for them to move online (ibid.). Also, in most small communities, the daily newspaper remains the most important source of classified and retail advertising.

In 2009, while the newspaper business was suffering its worst year in history, advertising revenue fell just 3.6 percent for dailies with circulation under 100,000 (Ovide \& Adams, 2009). As small-town Georgia newspaper editor Robert Williams Jr., told Reuters: "CNN is not coming to my town to cover the news and there aren't a whole lot of bloggers here either. Community newspapers are still a great investment because we provide something you can't get anywhere else" (Liedtke, 2009b). Another editor suggested that big papers took their readers for granted: "Too many newspapers have been operating in an ivory tower for too long. I answer my own 
phone. Some newspapers are just now trying to develop a relationship with the local communities they cover. Ours has been going on for 14 years" (ibid.). Downey \& Schudson summed the situation up with:

Many of those less battered by the economic downturn are situated in smaller cities and towns where there is no newspaper competition, no locally based television station, and, as is the case for now in many communities, no Craigslist. Those papers' reporting staffs, which never grew very large, remain about the same size they have been for years, and they still concentrate on local news. A number of them have sought to limit the loss of paid circulation and advertising in their print papers by charging nonsubscribers for access to most of their Web content. They are scattered across the country from Albuquerque, New Mexico, and Bend, Oregon, to Lawrence, Kansas, and Little Rock, Arkansas, to Schenectady, New York, and Newport, Rhode Island. Although they have not attracted many paid Web-only subscribers, their publishers say they have so far protected much of their print circulation and advertising (2009: 18).

As Los Angeles Times reporter Judy Muller put it: "Some 8,000 weekly papers still hit the front porches and mailboxes in small towns across America every week and, for some reason, they've been left out of the conversation" (2011). The reason these papers still do well in their markets is that they deliver information people want and need: "the births, deaths, crimes, sports and local shenanigans that only matter to the 5,000 or so souls in their circulation area" (ibid.) Even on the big-city level, we can see that, when something happens that matters deeply to people, they still turn to their daily newspaper. For example, when the New Orleans Saints won the Superbowl in 2010, the TimesPicayune had more than 500,000 single-copy sales $-300,000$ more than the paper had allowed for with its first run (Fitzgerald, 2010a). A year earlier, the election of the first black U.S. president, Barack Obama, "produced a clamor for newspapers that publishers said they had never seen" (Pérez-Peña, 2008). For example, the New York Times printed an extra 225,000 copies of its Nov. 5, 2008, edition, and the Washington Post sold 
350,000 special editions, priced at $\$ 1.50$ a copy (ibid.).

In Canada, some of the newspapers that did the best through the recession also were the smaller ones. The 2011 Newspaper Audience Databank (NADbank) figures showed that the communities with the highest per capita total newspaper readership were Charlottetown, P.E.I. (metro population, 64,487), Cape Breton Island, N.S. (pop. 135,974), Brandon, Man. (56,219), and Peterborough, Ont. $(173,400)$. Ninety-one percent of the population in Charlottetown and Cape Breton read the print or Web edition of a newspaper on a weekly basis. For Brandon, the figure was 89 percent, and for Peterborough, 88 percent. By comparison Canada's three biggest cities lagged with 80 percent for Vancouver, 76 percent for Montreal and 75 percent for Toronto (Houpt, 2012). The interesting thing about those figures is that the larger the city is, the smaller the percentage of people reading newspapers, from tiny Charlottetown and Brandon to the largest city in the country, Toronto. This is reinforced by the fact that 90 percent of respondents told NADBank they read their papers for local coverage. Torontonians can go to a variety of sources for news about their sports, businesses or municipal politics. In Brandon, people only have "one source of in-depth news about the Royal Manitoba Winter Fair" (ibid.).

As in the United States, while the big dailies were suffering through 2009-and Canwest teetered on the brink of collapse-some of Canada's smaller publishers were turning a profit. An example is Black Press Ltd., owners of a string of tiny dailies in British Columbia and Washington State with a total circulation of around 2.8 million and annual revenue of about $\$ 500$ million. Like his U.S. counterparts, the owner of the company, David Black, says that his small dailies benefit from a closer relationship with 
their communities and are better insulated from the effects of the Internet on advertising revenue. "Community newspapers are still the best place for retailers to advertise.... For the big metros, it's different. They were living off their classifieds. They have to reinvent themselves" (Ebner, 2009). Even more impressive is Vancouver-based Glacier Media, publisher of a chain of daily and weekly community newspapers from B.C. to Quebec, and such trade publications as the Western Producer. In 2009, the company posted a net income of $\$ 28.3$ million (Smith, 2009). The company was doing well enough that, when Postmedia started selling off properties to pay down debt, Glacier was able to pay $\$ 86.5$ million for a collection of B.C. papers that include the Victoria Times-Colonist, the Nanaimo Free Press and 20 community weeklies (Krashinsky, 2011 b).

There also is evidence that Canadian dailies are doing better than their U.S. counterparts in holding onto readers. Audit Bureau of Circulation figures for 2010 show virtually no decline in circulation among the newspapers that report to that agency, which assesses circulation for roughly half the dailies in Canada (Krashinsky, 2010a).

NADBank, which covers the other half, released figures for 2011 that showed the newsreading habit was still strong among Canadians-particularly in print. The agency's annual report showed that three-quarters of Canadian adults read a print or online edition of a newspaper every week, and print readership was on average three times higher than online (NADbank, 2011).

ONCE YOU include the rest of the world in the story, it becomes even more complicated. In the United Kingdom, the aggregate figures have presented a similarly depressing image of an industry in decline. From a total circulation of 38.5 million in 1965, British 
newspaper readership had dropped to 22.7 million by 2007 .

But if the detail in this broad canvas is examined closely, a different picture emerges. The Sunday tabloid/mid-market tabloid newspapers illustrate the most striking decline (20.9 million copies in 1965, 15.1 million in 1985 but only 8.7 million in 2007), with weekday tabloids faring slightly better but still losing 28.9 per cent of their market since 1985 (12.5 million to 8.8 million), despite the circulation success of the highly popular mid-market Daily Mail. By contrast, across the same period (1965-2007) the "quality" dailies have enjoyed 27.5 per cent circulation growth from 2.03 million in 1965 to 2.6 million in 2007 and even in the Sunday market, quality newspaper readerships have declined only 8 per cent across the last four decades; the Sunday popular market has declined by 58 per cent across the same period (Franklin, 2008: 632).

This raises a number of questions: whether this is reflective of a decline in newspaper readership or an improvement in the education level of the reader; whether the down-market papers are suffering greater competition from other media; both of the above. Also, in stark contrast to the situation in North America, the British community press has collapsed, with some losing as much as 77 percent of their circulation (Robins, 20). As Bob Franklin writes, the national dailies hold on, still selling some 10 million copies a day among them-but they're feeling the same pressures to monetize the Internet, and their conditions and solutions are complex and diverse. While the Murdoch-owned Times of London installed a paywall around its Web site in 2010 (Sweney, 2010b), the Scott Trust-owned Guardian has remained a steadfast champion of free information. The paper's editor, Alan Rusbridger, has said he believes free content is not only good business but that paywalls mean "turning away from a world of openly shared content" (Pfanner, 2010). Meanwhile, the Independent, more or less, paid "Russian oligarch" and former KGB agent Alexader Lebedev to take the Evening Standard off its hands (Schweizer \& Thiel, 2009), while 
one of its rivals, the middle-brow Daily Mail, boasts a print circulation of 1.9 million and online readership of 40.5 million -26.3 million outside the U.K. It runs its online and print operations as completely separate entities (Preston, 2010), and even though its income was down by 15 per cent in 2011 , it still declared a profit of $£ 125 \mathrm{~m}$ (Clark, 2011).

Focusing on the scholarly literature, Franklin complains of "an evident Manichaeism in the different futures which unravel for newspapers" (2008: 631). However, as we have seen, his comments are just as applicable - if not more so-to the ways in which the business has covered its own alleged demise. There is a widespread tendency among pundits to "make unrealistic extrapolations based on declining circulations to predict, with a curiously bizarre precision, the exact date on which the last newspaper reader will vanish" (ibid.). Frank Gurry is one example. Last year, the UN official told the Swiss newspaper La Tribune de Geneve: "There are studies showing that [newspapers] will all disappear by 2040. In the United States it will end in 2017" (Agence France-Presse, 2011). This could be taken as more hopeful than the forecast from "futurist Frank Dawson," who predicted "journalism will be increasingly crowdsourced [to] hordes of amateurs overseen by professionals" and that the newspaper would cease to exist in 2022 (The Australian, 2010). As Franklin put it:

[T The precocious pessimism and unwarranted hyperbole of those who wish to proclaim the imminent demise of the newspaper is clearly unsustainable. It articulates a curiously North American and Eurocentric view of the press which seems blinkered to the explosion of new titles and readerships in other parts of the world; the future of newspapers is more open and considerably more nuanced than some observers imagine (2008: 631). 
Likewise, Picard argues that the "crisis" in journalism is particular to "some countries" of the West and that "journalism is in a growth stage" elsewhere in the world, particularly Africa and Latin America $(2010,17)$. In 2008, while the bottom was dropping out of the market in North America, The Economist was citing figures released by the World Association of Newspapers that showed circulation increases of seven percent in Argentina, 12 percent in Brazil, 20 percent in China, and 11 percent in India-for a five-year increase of 35 percent. And there is evidence that the growth is even greater in countries where "Iglovernments with limited resources are ill-equipped to monitor a profusion of local and regional newspapers," WAN reported. "In Mali, for example, newspapers are popping up 'like mushrooms' " (Economist, 2008). Also, at a time when advertising was dropping in North America, global newspaper advertising spending was expected to increase from $\$ 125$ billion in 2007 , to $\$ 130$ billion by 2010 (Timmons, 2008).

In India, the industry is exploding, to the point that Indian companies are stealing work from North American journalists. The Times of India, with a circulation of around 3 million and a readership of more than 7 million daily, is the largest English-speaking newspaper in the world (Shirley, 2012). The Hindi newspaper NaiDunia has gone from 500,000 circulation to 800,000 in two years and is projecting a readership of 15 million by 2016 (Nolen, 2011). Rolling Stone, Vogue, FHM and Maxim have all launched Indian editions. Tina Brown and Tom Brokaw have advised aspiring North American journalists to go to India for work (New York, 2010). And there even has been an exchange program of sorts in which Columbia University students served apprenticeships at Indian dailies (Venugopal, 2008). 
Perhaps most telling, Indian companies have begun to capitalize on the situation in North America, by drawing work overseas, cashing in on the wealth of highly trained, English-speaking Indian journalists who are happy to work for a fraction of what North Americans earn. One example of such a company is Mindworks of New Delhi, which advertises itself on its Web site as a provider of "a range of editorial services for print and online including copy editing, design, layout, content aggregation, and website content management" (mindworksglobal.com, 2012). The company has provided services for a variety of North American clients, including California's Orange County Register (Lakshman, 2008) and the Miami Herald (Bridge, 2009). In the same way, the Chicago-based company, Journatic, farms out work to freelancers around the world, who make $\$ 10$ or $\$ 12$ an hour, roughly minimum wage, grinding out "local" stories - everything from amateur sports to garbage collection schedules - for newspapers across the United States. Understandably, American journalists are concerned about being replaced by such content farms, and the development has been interpreted as one more sign that the business of journalism is in deep trouble and is dragging the craft down with it (more on that in Chapter 6). Stories from Journatic have appeared in such papers as the Chicago Sun-Times, the San Francisco Chronicle and the Houston Chronicle (Shafer, $2012 b)$.

In Europe, where there is less reliance on advertising revenue and circulation has been falling more slowly than in North America, there has been a range in both the levels of crisis - from non-existent to menacing - and in the measures to deal with the situation. In 2009, while the sky was said to be falling in North America, the 62 - 
year-old German newspaper Bild reported its highest profit, and the Oslo publisher Schibstad was recording that a quarter of its profits were coming from online activities (Pfanner, 2009a).

At the same time, Europeans proved to be more willing to take measures to help their newspaper industries. To try to bolster its ailing dailies, the French government unveiled a plan to provide one-year free newspaper subscriptions to 18 24-year-olds (Pfanner, 2009b). In the 2000s, the Dutch newspaper NRC Handelsblad, a national institution, found its circulation dropping by 5,000 to 10,000 per year, and that young people weren't reading it. Its response was to launch, in 2006, a splashy digest of the paper's sexiest items, aimed at young readers. By 2008 , the paper's publisher claimed $N R C$ Next had made a profit of $\$ 3.3$ million on sales of $\$ 25$ million (Levine, 2009). In Belgium, a group of francophone newspapers calling themselves Copiepresse took Google to court and won a ruling that ordered the Internet company to remove their content from its aggregation site. The aim was not so much to protect or enhance profits, said the group's secretary-general, but to avoid "having giants killing us" (Pfanner, 2010).

IT TOOK a long time for the "Original Sin" lesson to sink in with newspaper publishers, but it appears that by 2011 the lesson finally had got through. It was then that, "after years of talk and no action, the industry began to embrace paywalls for digital content" and began to make the first moves towards wringing some money from aggregators (PEJ, 2102).

As we have seen, in choosing to give away their content, newspapers had 
gambled that advertising income would outweigh loss of circulation revenue, and had lost. As well, by making their content free, they provided a bonanza for aggregators, such as the Huffington Post, Daily Beast, Yahoo and Google, which could cherry pick the best material from a variety of sources and run it, often in digest form, on their sites for free. It also was something of a gold mine for bloggers, such as the famous Matt Drudge, who could, in effect, create op-ed pages that gathered and dissected the news produced by the papers-often while adopting an anti-mainstream media pose. In short, everyone but the newspapers seemed to be profiting from the newspapers' investment in news.

At the same time, by giving away the product, the newspapers had devalued it. Throughout the modern history of the publishing business, there had been a sharp divide between publications for which a consumer was willing to pay and the 'advertising rags' that were given away for free. The former carried with them a stamp of quality in the sense that they had a market value and the fact that they continued to exist validated that value. The give-away, on the other hand, was expected to be filled with promotional bumpf that was there mainly to create a raison d'etre for the ads. Strangely, when the newspaper publishers decided to give away their content, it never seemed to occur to them that, in appearance at least, they might be pushing themselves towards the realm of the latter. As James Harding, editor of the Times of London put it: "Saying our journalism is worthless and dumping it free online is not a viable economic model" (Pfanner, 2010). So, an important subtext to the discourse about broken business models, debt crises and dwindling share prices was the question of who was going to fund quality journalism if the newspapers killed 
themselves with their generosity. The issue had become, as Bill Gates had once put it in a protest letter to software pirates, "Who can afford to do professional work for nothing?" (Isaacson, 2009). So, for once, the business and editorial sides of the newspaper industry had a cause in common; where they often parted company was in the solutions they suggested.

IT WAS in 2008 that the U.S. audience tipped over and more people began to get their news online than in print (Pew, 2008), and it was then that newspapers began to talk seriously about finding a way to monetize the huge audiences they were building online. Attempts to establish subscription or pay-as-you-go systems date back to 1996 , when Slate magazine debuted with the idea of eventually putting up a $\$ 19.95$ per-year paywall, which it did in 1998, only to take it down a year later (The Week, 2010).

As noted earlier, the most successful paywalls have been ones created by specialty organizations, such as the Wall Street Journal's, set up in 1997, because they deliver information that has an established value to an audience with no other way to get it. When there are alternatives, it's a bit trickier. For example, in 2003, the Los Angeles Times put up a $\$ 4.95$ paywall around its online arts and entertainment section, and took it down two years later, after experiencing a 97 percent drop in readership (ibid.). Not surprisingly, there was no shortage of alternative coverage of the entertainment industry in Hollywood. In 2005, the New York Times put its archives and columnists behind a $\$ 50$-per-year paywall, but aggregators still found a way to link and it came down two years later (ibid.). In 2007, the Financial Times 
invented the metered paywall - where readers get so many stories for free before having to pay - which is shaping up to be the favoured model for the paywalls being introduced in 2011 and 2012 (ibid.).

The conversation about paywalls has taken the form of an argument between two points of view: attracting a percentage of the audience that is willing to pay has always been what newspapers do and the only way they can remain solvent is to do it online; news has always been free, because advertising always paid for it, and asking readers to pay will just force them to go elsewhere, reduce the size of the audienceand reach of the newspaper-and make the site less attractive to advertisers. Besides, the latter group argues, for a very small fee, aggregators will be able to take the content and make it available to everyone on the Web. It has been a hard argument for anyone to win, because all the data seem to have a dual application.

For example, a Harris poll conducted in 2010 showed that 77 per cent of Americans would stop reading newspapers online if they had to pay for them (Chittum, 2010a). A first glance this appears to be a resounding denunciation of paid content. However, as the Columbia Journalism Review's Ryan Chittum points out, that also means that 22 percent of Americans are willing to pay-compared to the 19 percent who buy newspapers (ibid.). In other words, the Internet has created a new mindset not just on the part of the audience member, who expects everything for free, but also on the part of the publisher, who expects to be able to talk to a worldwide audience of millions where, in print, a few hundred thousand would suffice. Meanwhile, in Canada, the reaction against paying for content is slightly stronger, with 81 percent saying they definitely would not pay for content, and 92 percent 
saying they'd find another free site if their favorite site began charging (CMRC, 2011). It's not clear how to interpret those numbers - perhaps that readers of Canadian newspaper Web sites find the information useful but not so compelling as to be worth paying for. Further, using Chittum's logic, 81 percent who won't pay leaves a pool of 19 percent who would. And finally, in both cases there is a large hole in the research. Why did no one think to ask respondents whether they read a newspaper as well as reading news online, and whether they'd give up the print version for digital at the same or a lower price?

Newspapers are beginning the process of finding out, the way they always do: late, reluctantly and through trial and error. After some four years of waiting for business to return to normal, the newspaper business is finally doing what radio and movies did before them, reinvent themselves for a new reality. And, as always, it has been the little guy who took the initiative-while no one noticed. In 2011 , shortly after the New York Times finally rolled out its pay model, the University of Missouri School of Journalism conducted a study that found 46 percent of U.S. papers with a circulation less than 25,000 were already charging for at least some online contentand only 24 percent of larger newspapers were doing the same. The study also revealed that another 35 percent of smaller papers said they had plans to start charging. "There was so much build-up to the New York Times pay model, and when they finally rolled it out, a lot of people were watching that. But it wasn't like the smaller newspapers were waiting for the Times to get its act together ... Small papers are more nimble" (Levine, 2011).

As for the larger papers, Long Island's Newsday was the first to erect its 
paywall, in October 2009. It allowed full access for subscribers to the print edition of the paper or the parent company Cablevision, or for people willing to pay $\$ 5$ per week. For everyone else, all that was available was a headline and a summary of selected stories; classifieds, listings, weather and obituaries remained free (Strupp, 2009a). By 2010, Newsday had reportedly signed up only 35 online subscribers. But more important, according to the publishers, is the fact that Newsday readership in the New York area had declined by only two percent, meaning that putting up a paywall had served only to drive away "the junk traffic from outside New York," about whom neither the publisher nor the advertisers cared (Chittum, 2010). In July 2010, the Times and Sunday Times of London put up a rigid, subscriber-only paywall around their Web site, and watched as circulation evaporated; only 14 percent of Web readers were converted to subscribers (Bercovici, 2010). A year later, the circulation of the Times print edition fell another 13.3 percent, the largest drop of any non-tabloid British daily (Taylor, 2011), and its U.K. Web traffic (the audience that matters to advertisers ) was down 42 percent (Chittum, 2012b). Then, in March 2011, the New York Times launched a metered paywall whereby readers would be allowed a to read 20 stories a month for free and only be charged if they wanted to dig deeper into the site. The system also has a range of subscription rates for online, smart phones and tablets, or all-access. It is also a flexible system that allows for Times editors to set the meter to zero in the event of a big news story, like $9 / 11$, in which the demands of public service supersede business (Peters, 2011 b). Basically, the plan punishes the fans for being loyal and rewards the fly-bys for being flighty - but it works. The paper has retained its trophy audience of 30 million worldwide, while finding a way 
to get the 14 percent of the readers who are responsible for 75 percent of the page views to pay for their habit.

The paper has calculated, correctly, that it can keep the ad revenue while adding tens of millions of dollars from subscriptions. Traffic (unique visitors) is actually $u p^{3} 2$ percent at nytimes.com since the meter went up and it took in 6 percent more in digital advertising in the third quarter than it did a year ago without a meter (Chittum, 2012b).

So, mow that the Times has shown that it is possible to be profitable in the digital age, the race is on to launch paywalls. Newspapers across the United States are looking at the Times model. In Canada, the Globe and Mail has put up a paywall and Postmedia has announced that it will follow suit. In May 2011, Postmedia announced a pilot project to test the Times model on some of its newspaper Web sites (Krashinsky, 2011), and a year later, the Globe and Mail announced it would launch a metered pay wall patterned after the one at the Times (Ladurantaye, 2012b). In August 2011, Media News, owner of the Denver Post, announced an online subscription system for two-dozen of its papers in five states (Harden, 2011). In September, the New York Times-owned Boston Globe put up a paywall, which allowed only subscribers to read the full contents of the paper online (Pulley, 2011). In October, the Minneapolis Star-Tribune created a paywall (Owen, 2011), and Gannett announced plans to put paywalls around all of its 80 dailies - everything but USA Today (Bercovicic, 2012). In April 2012, Postmedia announced its pilot project had become a project, with a metered paywall going up around big city dailies over the course of the year (Financial Post, 2012b).

And the newspapers also are finally addressing the issue of aggregation. The

\footnotetext{
${ }^{3}$ His italics.
} 
Times, along with the Washington Post and Gannett, launched Ongo in early 2011, a subscription service that delivers news from a variety of sources; sort of a subscription aggregator (Reuters, 2011). And U.S. newspapers are finally looking for ways to get second-party publishers to pay for the content they take. In 2011, Associated Press and 28 other news organizations launched NewsRight, a rights agency that will attempt to get aggregators and others who poach news content to pay licensing fees for it (PEJ, 2012).

THE PAYWALL isn't the only idea anyone has had, but so far it appears to be the most effective way to keep the model of journalism functioning as a business, an art and a public service, and as a separate entity from government. In the United States, commentators such as Downie \& Schudson (2009) have suggested alternative models ranging from the setting up of partial tax-exempt status for news companies, in the form of corporations that would be able to receive tax-deductible donations and foundation grants, a push for foundations to fund journalism, university involvement in news gathering and dissemination, and government subsidies for local news. McChesney and Nichols (2010) make some of the same recommendations, along with advancing the concept of community ownership-like the Green Bay Packers or Saskatchewan Roughriders football teams - and the novel concept of a "Citizenship News Voucher," a $\$ 200$ credit every American would get from the federal government, which she or he could donate to the news outlet of his or her choice" (ibid:: 201). New York Daily News publisher Mort Zuckerman has even suggested that newspapers be allowed to subsidize themselves by offering sports betting on their 
sites (Smillie, 2009).

There are non-profit organizations such as Minneapolis's Minnpost and the Voice of San Diego, and the "robust, well funded ProPublica," that had a budget of $\$ 9$ million in 2009 , just two years after its founding (Carr, 2009c). Each aims to provide high quality online journalism that relies on foundation and donor funding (more about this in the next chapters).

There have been experiments with hyperlocal Web sites, in which large news organizations tried to behave like community papers, without actually being part of the community, and one interesting experiment at the Journal Register company, owners of a chain of small dailies and community papers in the U.S. northeast. The brainchild of its Canadian-born CEO John Paton and called the "Ben Franklin Project," it involved putting out all the publications in the chain with alternative online tools and freeware such as Google Docs, YouTube, the photo-editing tool GIMP and the layout program Scribus. It also involved using as much user-generated content as journalists could lay hands on (Kirchner, 2011: 45). And there are even papers that have come to question what may be the core belief of daily newspaper orthodoxy: that a newspaper must be daily. In 2009, the Detroit Free Press cut back home delivery to three days, although it still publishes every day for newsstand sales (Salter, 2009). And, in 2012, the New Orleans Times-Picayune announced plans to cut back its print product to three days a week, publishing only online on the other four days (Farhi, 2012).

IT WOULD be premature to declare the crisis past. Newspapers are still cutting jobs 
and chains are still carrying large debts. Tribune is still in Chapter 11 , and there are companies, such as Quebecor, that seem determined to harvest their print properties, without having much of an idea of what to put in their place once they've stripped them of their value. Some newspapers, such as the New York Times have seen the value in maintaining their news staff and, as a result, have something valuable that they can sell online. Others may have cut too close to the bone to be able ever to produce anything valuable enough to be worth even the fees presented by a metered paywall. As Morton says, with its cost cutting, the newspaper industry has sacrificed "the one attribute that has protected it against all previous competitive threats - the overall quality of its journalism" (2011). There likely will be newspapers-such as the Globe and Mail and Daily News-that will stick with print, and it's likely there will at least be a niche market for print, at least some days of the week, notably Sundays.

As Picard has pointed out, there never was a problem with the business model, but rather the problem was with the "revenue model" $(2010,18)$. At the heart of the industry's troubles, he argues, are financial pressures built up over years of focusing on short-term gains and ignoring long-term trends, a reluctance to accept new media consumption patterns, and an unwillingness to let go of ways of conducting business that were built up-with large media organizations-in good times (ibid.). The business - in terms of manufacturing the product and getting it to the audienceworks fine; the problem is in getting paid for it, a familiar refrain.

Finally, there has been the, perhaps unfair, question of management, and the role it has played in the crisis. Would Tribune have fared better without Zell? Should 
Gannett be paying its executives bonuses while it forces staff to take unpaid furloughs? (Carr, 201 la). Daily Beast founder Tina Brown (2008) has gone so far as to call the heads of media chains "feckless zombies ... who cared only about the next quarter's numbers ..." And Todd Gitlin has compared relying on the "myopic, inept, greedy, unlucky, and floundering managers of the nation's newspapers to rescue journalism" to "leaving it to the investment wizards .... to create a workable and just global credit system ..." (2009). Alterman warns that the state of the news business "is far too important to be left in the hands of a few clueless media moguls and their 'chief innovation officers' " (2009b).

The crisis has been a long time coming. I recall sitting in Ben Bradlee's office nearly twenty years ago and listening to the legendary editor bemoan the fact that it was all but impossible to get young people to pick up a copy of the paper. And that was before we had ever heard of the Internet, much less Craigslist. Twenty years is a long time to watch your business model die. To believe in the notion that, in the midst of the cost-cutting mania that is sweeping the business, we are likely to stumble onto a new source of profit sufficient to sustain the size of the news gathering and dissemination operations we've enjoyed in the past is akin to placing one's faith in divine intervention (ibid.).

So, it is perhaps no surprise that the debate over the future of the news business "has for the most part, been presented as a matter of mechanics and ledgers rather than one of turmoil of journalists and danger for democracy" (McChesney \& Nichols, 2010: 19). Over the years, we have come to link journalism so tightly to those media companies that much of the current discourse has taken it for granted that what is bad for the big media companies must also be bad for journalism. This may not necessarily be the case-despite the carnage on the labour front. As Guardian editor Alan Rusbridger points out: "If you think about journalism, not business models, you can become rather excited about the 
future. If you think only about business models you can scare yourself into total paralysis" (2010).

Finally, perhaps the most hopeful sign of all is that the innovations and successes seem to mostly be coming from non-chain papers like the Guardian and Telegraph in Britain and the New York Times, the Globe and Mail, the Daily News, the Seattle Times and the Winnipeg Free Press, and the hordes of little papers that operate under the radar, talking to their communities and making a profit, without anyone in the big leagues ever noticing them.

On the negative side, none have come up with a business plan that answers the question of how to make a consistent profit in the Internet age. Even the New York Times, which has been among the most aggressive companies in exploring ways to use the Internet for technology and journalism, is struggling to maintain income. The Times Company reported a net loss of $\$ 88$ million for the second quarter of 2012 , blaming a write-down in the value of its About.com subsidiary and declines in print and online advertising. At first glance, that compares favourably to the net loss of $\$ 119.7$ million the company posted in the second quarter of 2011 - until you factor in the fact that there was an operating profit of $\$ 31.5$ million, offset by a write-down in the value of the company's regional papers, which it has since sold. This year, the company posted an operating loss of \$143.6 million. Advertising at the company's News Media Group (which includes the Boston Globe and the International Herald-Tribune) was down in both print (eight percent) and online (1.6 percent), while circulation revenue was up 8.3 percent, owing to an increase in the price of the Times print product and a rise in online subscriptions (Chozick, 2012). If you take the Times as a microcosm of the big-city North American 
omnibus daily, this is a strong indication that the normal state of affairs for much of the business, in the foreseeable future at least, will be unreliable advertising income and an increased dependence on circulation, online subscriptions and other revue to make up the difference.

THE NEXT chapter looks at the digital revolution strictly from the technical side and asks, What does this mean for journalists and journalism, as well as for the media business? 


\section{The dialectic of gloom: technology}

THIS THESIS could be written without current technology, but I'd rather someone else tried it. Research has been mostly a matter of plugging in, following the links, and waiting for the stories to unfold, thanks to: aggregators such as iCurrent, Media Bistro, J-Source and Daily Planet; blogs such as PRESSthink, Reflections of a Newsosaur and Paper Cuts; the extensive archives of organizations such as the Poynter Institute, the Pew Research Centre and Neiman Labs; as well as various pdfs, and RSS and email feeds of trusted and favourite journals, newspapers and magazines. Of course, there were books as well-but one was available just on smart phone or tablet. And, with Instapaper, you can file away massive amounts of material without printing or worrying about expiring bookmarks. If anything, the challenge is in sifting through the volume of information spat out over time by the communications technology - not to mention the cold, nagging fear of waste that seems to go hand-in-hand with being on the receiving end of so much knowledge.

Spot research and verification are almost embarrassingly easy: a few keystrokes and the answer to virtually any question pops up on the screen. "What is the largest English-language newspaper in the world?" Hit "enter," and dozens of pages on the Times of India appear, with circulation and readership figures. All one needs is to be patient enough to read enough of the material to discern the most recent, verifiable figures. Writing, editing, revising and citing are all one fluid process, thanks to Word. And the Cloud keeps finished work safely backed up on a hard drive in Belgium, Switzerland, or 
Cupertino, Calif.

These are tools anyone can use. For someone with the time and inclination to become adept at computer-assisted reporting and data-base building, the Internet has constructed the most massive library of record that has ever existed, and it grows exponentially by the day. This enables a whole new style of journalism that can turn statistics into everything from accountability research, to narrative, to elaborate, interactive mapping projects.

However, Internet research is just the largest and most obvious benefit of technology. Computer pagination has turned every copy editor with a sense of composition and perspective into a graphic designer. New and simpler Internet design applications have turned every graphics person into a Web designer. Pocket digital cameras and Photoshop have made every reporter a reasonably competent photographer. Digital slide-show technology has made every photographer a writer, filmmaker and storyteller. Smart phones have made every citizen a witness, and potentially a journalist. Web sites enable newspapers to be repositories for audio, video, interactive graphics and even primitive games, and allow every television network to turn its reports into text. The New York Times and the Guardian become audio-visual feasts, and the Canadian and the British Broadcasting Corporations, and National Public Radio become journals of record. Technology enables participatory journalism that takes old standbys like the "streeter" interview, the tip line and the letter to the editor and turns them into new forms of communication and research: crowd-sourcing, citizen journalism and comments fields. "[W]e now have a platform that creates both expressive power and audience size. Every new user is a potential creator and consumer, and an audience whose members can 
cooperate directly with one another, many to many, is a former audience" (Shirky: 2008, 106). The technology can be dizzying, confusing and sometimes terrifying, but it is never boring, and the discussion around it is rarely gloomy -although it does come with its share of moral panic, evangelizing, nitpicking, and societal worries and complications.

For the most part, technology has revolutionized and enriched the practice of journalism in ways we probably won't come to appreciate for years. The modern postal system helped create the press; mass literacy and the steam press enabled modern massmarket journalism; the radio brought about the intimacy of the spoken newscast and the direct democracy of the Fireside Chat; television put the audience at the scene of the event as it happened. The new technology works with a speed that leaves even television and radio at the side of the road choking on dust. It allows events to be photographed, videorecorded, written, tweeted, emailed and posted as quickly as they happen, and it is so rife with opinion that it has created a world in which truth is often relative to when it is told and how it is interpreted. As Robert Darnton put it, "News is not what happened, but a story about what happened" (2009: 25). With its waves of images, text and opinions, the Internet puts a very fine point on that. And, perhaps most important, it puts what Jay Rosen calls "the people formerly known as the audience" (2006) into the conversation, and not just as sources and hecklers, but as auditors, analysts, commentators and reporters. The objects of the news have become its subjects.

There have been two conversations going on about journalism and technology over the past four or five years that are like the light and dark sides of the moon. On the dark side, this technology has been feared as the destroyer of big media, or worshipped as the machine that would save it - and is used repeatedly as "air cover," to steal a line from 
Tina Brown (2008), for big media's inability to manage a budget, plan for contingencies and adapt to changing times. "The Internet broke our business model" has become the "dog ate my homework" of news executives everywhere.

On the light side, however, unyoked from the dismal machinery of business, the talk has been about a revolution not just in the practice of journalism, but in its philosophy as well. In the shadows of the depressing discourse about debt, falling revenue, bankruptcy protection and "broken business models," a conversation has been going on about the new technology that involves an "irreversible trend in society."

It's a trend about how people are expressing themselves, about how societies will choose to organize themselves, about a new democracy of ideas and information, about changing notions of authority, about releasing individual creativity and an ability to hear previously unheard voices; about respecting, including and harnessing the views of others. About resisting the people who want to close down free speech (Rusbridger, 2010).

It also represents a continuation of the stresses and tensions over which theorists have been arguing since Dewey and Lippmann: whether we're creating a Great Community of universal discourse on the Web, or just a larger, louder, more loutish and even more atomized Great Society that, immersed in its noise and distractions, has become easy pickings for the opportunists and manipulators, who would have us vote away our rights and lapse into the sleep of media dreamers, so lost to the real world that we no longer bother to deal with it.

THAT SAID, this chapter is a fairly straight-forward examination of the technological innovations that have moved into the news industry over the past four or five years. No doubt some - as with videotext, fax-delivery and audiotext-will prove to be 
evolutionary dead ends, and others will transform the ways in which we use media. This chapter also has a place for so-called "old" technology, the printing press, because there are many who believe it still has a role to play in the new world-and the continuing success of the British "quality" dailies and U.S. Sunday editions indicates that there may be areas where ink-on-paper is still the most advanced technology.

There are some areas of overlap with the previous chapter and the next. Hyperlocal journalism, for example, is something some major dailies have put in place basically to try to emulate the success of community papers. For the most part, technology has enabled it by making it inexpensive, and it represents a change in how journalists aspire to do their work. So it merited a mention in Chapter 4, and will pop up in this chapter. The same is true of participatory and citizen journalism, and crowdsourcing; technology has allowed these things to develop as they have, but they have a powerful bearing on how journalists see their craft and how-or indeed whether--they will do their jobs in the future. Similarly, theories of the ways in which media companies organize the structuration, commodification and spacialization of journalists' work have been greatly affected by the new liquid work environment, as have the notions of employment in relation to the media crafts (Mosco, 1996; Deuze, 2007). All this has been enabled and expanded by technology as well as the global economy, and they affect the craft of journalism.

IN JANUARY 2009, New York magazine ran an article by Emily Nussbaum, under the cheeky title, "Goosing the Gray Lady." It was about "a group of developers-slashjournalists, or journalists-slash-developers" (Nussbaum, 2009), who were inventing the 
newsroom of the future inside the traditional workings of one of the world's most respected journals of record, the New York Times. The story began with a description of an online election poll, called "The Word Train." It asked readers, "What simple word would describe your current state of mind?" From a menu below the question, participants could choose from a list of adjectives and say whether they supported Barack Obama or John McCain for U.S. president. The results ran in six rows of words, in Republican red or Democrat blue and descending point sizes. "The larger the word, the more people felt that way. All day long, the answers flowed by, a river of emotion. ... It was a kind of poll. It was a kind of art piece. It was a kind of journalism, but what kind?" (ibid.)

The glib answer to that question is, An imaginative, fun and thought-provoking kind. And it is really not surprising that the Times was doing it before most. Despite its reputation for being the "gray lady," the Times has long been one of the more interesting products in the daily newspaper business, in terms of creativity. Around the time the Web was being born - and shortly after it pried itself away from the antiquated black-andwhite vertical layout that gave the Times its reputation for clinging to tradition-the paper was using its big Sunday edition as a graphic design and story-telling laboratory. The Huffington Post didn't invent "mullet journalism" (business in the front, party in the back); the Times did. The "A" section may have been sombre and predictable, but "Arts \& Leisure," "The Week in Review," "Style" and the Sunday magazine supplement were where you could find the stories that were good just for being good: a day with Jerry Seinfeld as he re-invented himself as a stand-up comic; how Steinway builds a piano; a feature on the funeral industry, with the type set in the shape of a coffin, against a 
background of blue sky and puffy clouds; a glossy black magazine cover with the first paragraph of a story set in large white type, and the headline in small red type at dead centre of the paragraph. To anyone who was paying attention, it was clear the Times understood the balance between public service and creativity.

Yet, what is most telling about the story of the online team is that it was unfolding as the newspaper industry, and the Times company, were going through their worst financial crisis in history. Shares were plunging, advertising was dissolving, and circulation was shrinking. Even the mighty Times was forced to borrow $\$ 250$ million from one of its investors, Mexican billionaire Carlos Slim Helú. Things were so dire that Atlantic Monthly ran an article speculating that the paper might be on the verge of closing down entirely (Hirschorn, 2009). Yet, while the best ideas of many other newspapers consisted of laying off employees and cutting back on the product, the Times was looking for ways to expand its reach and voice. Times media reporter David Carr told New York, 'This notion of 'Let's give it a whirl,' that's not how we act in our analog iteration. In our digital iteration, there's a willingness to make big bets and shoot them down if they don't work. And yet it's all very deadly serious. Other print websites can innovate because nobody's watching. Here, everybody's watching" (Nussbaum, 2009).

That blend of creative freedom and management pressure appears to get results. In 2008, the Times Web team was producing features such as: "Casualties of War," an interactive map showing the home towns of U.S. military killed abroad; "Lourdes of Twang," a fascinating audio-slide show that takes viewers inside the Martin guitar factory; "The Collapse Sequence," a multi-page interactive graphic reproduction of the collapse of a massive construction crane in midtown Manhattan (nytimes.com, 2008). 
Perhaps the most impressive recent effort-and one that showcases all the strengths of the Times's online team-is "The Reckoning," a magnificent, beautifully designed compendium of text, audio, video and interactive features commemorating the 10th anniversary of the World Trade Center attacks (nytimes.com, 2011). If the Times wasn't exactly writing the manual on online journalism, it was contributing a very interesting chapter.

It wasn't just at the Times that publishers were aggressively experimenting with the Internet. In Britain, The Guardian was in the process of another reinvention. Founded by the Scott family and, since 1936, owned and operated by the Scott Trust set up by the last surviving heir of the family, the Manchester Guardian had by the mid-20th century established itself as Britain's only non-London national daily - until, in 1976, it moved south to the nation's capital and became simply the Guardian. So, it was with a history of outsized ambitions that the paper took itself online in 1995. Four years later, it became the Guardian Unlimited network of Web sites. Today, the Guardian News \& Media Website Network claims to have more than 69 million unique monthly viewers (guardian.co.uk, 2011). Guardian editor Alan Rusbridger describes the paper's online philosophy as to be "of the web, not simply be on the web..."

Journalists have never before been able to tell stories so effectively, bouncing off each other, linking to each other (as the most generous and open-minded do), linking out, citing sources, allowing responseharnessing the best qualities of text, print, data, sound, and visual media. If ever there was a route to building audience trust and relevance, it is by embracing all the capabilities of this new world, not walling yourself away from them (2010).

It's interesting that the best of the traditional media companies have been the most adventurous online. A list of Webby award nominees and winners over the past five years 
for "best news" and "best newspaper" (a category discontinued in 2010) is dominated by traditional media companies: For the three years of "best newspaper," the Guardian and Times have three nominations each, with the Guardian winning twice and the Times once. For "best news" site, the Times has three nominations and two wins, the BBC three nominations and two wins and National Public Radio three nominations and one win. Other nominees in the "news" category include the aggregators Huffington Post and Daily Beast (two each), online magazine Salon (with three), and news sites the Guardian, Truthdig, Reuters, CNN, Discovery News, Wired, MSNBC, and the Wall Street Journal (one each) (webbyawards.com). Two things stand out about the "news" category: aggregators and originators, and broadcasting and print, compete on the same playing field. This implies that a) presentation is more important than source and b) the Internet is not a medium; it is a space, in which all media, as Rusbridger said, merge, meld and compete for attention. As the Guardian's then managing editor (now reader's editor) Chris Elliott said in 2010, one of the most powerful forces promoting quality journalism online in Britain is the BBC. "We have to be more aggressive and cover more things in more creative ways because we aren't just competing with other newspapers, we are competing with a BBC that is serious about journalism" (McChesney \& Nichols, 2010: 163).

THERE IS a wave of technological experimentation going on at news companies that ranges from ways to utilize freeware to involving readers in research and development. One of the more interesting of these was the Journal Register Company's "Ben Franklin Project." On July 4, 2010, all of the company's 18 small-market dailies in the 
U.S. East and Midwest "declareld] independence from expensive proprietary software" (Kirchner, 2011: 45). That is, in place of such pricey applications as Photoshop and Quark or InDesign, they put out their papers using such downloadable free software as GIMP and Scribus, as well as more familiar tools, such as YouTube, Google Docs and CoverItLive. Journal Register CEO John Paton told the Columbia Journalism Review he had calculated that upgrading technology for the company would have cost $\$ 25$ million. The freeware experiment helped him get that budget down to $\$ 12$ million (ibid.). At the same time, Paton said, the project "allowed audience members to help shape editorial story budgets through crowd sourcing" (Fitzgerald, 2010b). Other Journal Register innovations include: giving the reporters flip cameras to record video, and the institution of IdeaLab, which gives editorial employees Web tools and the time to tinker with them (Kirchner, 2011: 45-46). Unfortunately, the experimentation has yet to translate into profit. In September 2012, the chain's Digital First parent company went into Chapter 11 bankruptcy protection for the second time in three years-after refusing to join the movement towards paid online content (Digital First, 2012).

And then there are the papers that have chosen to reinvent themselves online, such as the Christian Science Monitor and The Seattle Post-Intelligencer. The Monitor, a well respected, 100-year-old, limited-profit daily dedicated to quality journalism, has evolved from broadsheet to tabloid, to a print and online publication consisting of a constantly updating Web site, a daily pdf e-edition and a weekly print edition. In effect, in 2009 , it transformed itself from a newspaper to a brand, comprising a Web site, a daily newspaper and a weekly news magazine - and saved millions in operating costs at the same time (Moozakis, 2009). 
The 146-year-old Post-Intelligencer, on the other hand, was the loser of an oldfashioned newspaper war, as was the Rocky Mountain News. Both were artifacts of the days when cities regularly had competing dailies. As David Olive has written, "The real story of the Seattle Post-Intelligencer and Denver's Rocky Mountain News is that they hung on as long as they did" (2009). However, whereas the owners of the News took the old route and simply shut the paper, the Hearst Corp., which owns the $P$-I, transformed it into something new: a news-and-opinion aggregator with "a robust community news and information Web site at its core" (Moozakis: 2009). The paper has since launched apps for smart phones and tablets, and from a quick tour of its Internet offerings, appears to have settled into life as a fairly typical mid-market site, with a focus on local news, sports, entertainment and news you can use. On the day l accessed it, the focus was a rotating box, alternating between a photo gallery illustrating bike laws, and the " 10 Seahawks to Watch." The news headlines dealt with a car accident, Seahawks' running back Marshawn Lynch being arrested for driving under the influence, and film of a bobcat that tried to break into a prison. There was a story on Mitt Romney's presidential campaign, an account of a rape and a short item about an embarrassing tweet from a local candidate's aide. The last was from KOMO TV; the film was a found item; and the rest were done by seattlepi reporters. Below that first screen, the site could have been any aggregator. The closest thing to a user-involvement element on the home page was a box listing the "most read," "most commented" and "most tweeted" items. Finally, of course, the stories all featured comment fields. In other words, the site looks like what it is: something done on a shoestring budget with a tiny staff, and following all the conventions of a site geared to collecting an audience for advertisers (seattlepi.com, July 
17, 2012).

The Web site of the surviving print daily, the Seattle Times, on the other hand, ran under a traditional masthead heralding the fact that the paper was "Winner of the 2012 Pulitzer Prize for Investigative Reporting." It was organized like a typical newspaper Web page, with a first screen of two news stories, a sports photo, a "This Just In" list of bulletins and three photo-promos throwing to other "sections" of the site. The one offbeat item was a very strange, unlabelled, interactive maze at top right, where the reader could guide an electronic "pencil" to the finish and be automatically linked to a "celebrity quiz." Directly below this unexplained oddity, as one scrolled down, was the item "Trending with Readers" (seattletimes.nwsource.com, 2012). The difference between the two sites appeared to be strictly a matter of resources; there was nothing terribly imaginative or interactive going on at either. The Times's site read like a good, print, mid-size city daily, and the $P-I$ looked like the poor cousin that was losing the circulation war. Neither is revolutionizing online journalism.

Other initiatives range from the New York Times's research-and-development group, which plays around with program and application prototypes for the paper's content (Strupp, 2009b) to the paper's launch of BETA620, a public beta-testing site for the new products the paper's R\&D people dream up (Advertising Age, 2011). One of the things it offers is a Browser plugin called "Test Drive" that allows Times readers to test out new products as they are unveiled (beta620.nytimes.com). Some newspapers, including the Tribune-strapped Los Angeles Times, are experimenting with an application called Visual DNA, which allows readers to create a personalized news page based on demonstrated interests, much the way Amazon compiles data on users' tastes from 
previous purchases, and then suggests new book, movie and recording releases (Behling, 2010). There are even experiments going on with news-producing algorithms, and prototypes have been tested with sports and finance stories. Developed by the Medill School of Journalism and the Engineering school at Northwestern University, the algorithm is called Statsmonkey and it can use the running score and other statistics of a football game to construct a story of the game. Though the copy it produces is mechanical and predictable, there's nothing in it to give away the fact that it was produced by a non-human. In fact, the target is that 90 percent of readers should be unaware the stories are machine-made (Bunz, 2010).

ASIDE from BETA620 and the "Ben Franklin Project," none of the above addresses what may be the most pressing issue: how to use the new technology to involve an audience that is coming to think of itself more as a public and less as a crowd. More and more members of this audience are demanding to be part of the conversation of the culture. This presents news media, particularly newspapers, with the challenge of not only reinventing the way they do business and deliver news, but how they think about and practice their craft. The transition to participatory journalism demands as great an effort of the performers as it does of the audience - if, in fact, there will be any division left between the two.

Freedom of the press, the old saying goes, belongs to those who own one. Now, thanks to the Internet, that includes all of us. This has led to an explosion in blogs, alternative news sites, online magazines, citizen journalism and sites such as YouTube that specialize almost entirely in user-generated content. From the Drudge Report to 
Talking Points Memo, to Truthdig, the Web is host to an explosion of alternatives to the mainstream press, the likes of which have not been seen since the flowering of underground newspapers in the late 1960s. As in the '60s, much of it is bred of discontent with the press and its definition of Hallin's three regions of journalism. And, as then, a lot of it has to do with redefining the spheres of consensus, legitimate controversy and deviance (Hallin, 1989: 116-117). So what if the New York Times and the Wall Street Journal place the Occupy Wall Street movement in the Sphere of Deviance? At Truthdig, former Times correspondent Chris Hedges has it firmly in the Sphere of Consensus. Unlike the 1960s, however, everyone can have a say in this conversation, even if it is simply by contributing to the comments field at the end of a news story. As a result, more and more newspapers are demanding that their employees pay attention to what matters to their readers. They have to; their financial lives depend on it.

Two years ago, Canadian journalist Wilf Dinnick told the Globe and Mail that he was on a mission to take "the traditional model of reporting" and turn it upside down. His "ultimate journalistic wish list," he told the Globe, included "total transparency, a story that never dies, and crowd sourcing" (McLaren, 2009). So, he founded OpenFile, a 'chain' of Internet news sites that, as of September 2012, serves the Canadian cities of Vancouver, Calgary, Toronto, Ottawa, Montreal and Halifax. The first thing you see when you open the OpenFile home page is this headline: "OpenFile is Community Powered News: You (the readers) tell us what is important and a professional journalist does the rest." In Vancouver, the stories are about a competition to build public housing, an indie comic-book publisher and smokers violating a ban on lighting up in parks. In Calgary, they are about protests over the closure of an access ramp at an LRT station and 
a service report on saving money. In Toronto, there are two pieces about a shootout at a block party and a couple of stories about cab driving in the city. In Ottawa, there's a poll on people's favorite outdoor space; in Montreal, a mother is deported against the wishes of her doctor; in Halifax, the lead is a sentimental piece about a historic pub being torn down for a supermarket. This is not like a typical chain of newspapers, where groupthink and pack journalism produce cookie-cutter reproductions with only slight variance from city to city. Each city page has its own flavor and set of priorities. And on every city page, there are two features: "Suggested Stories," in which readers get to vote for the ones they'd like to see written, and "Suggest a Story" (OpenFile.ca). At the average newspaper Web site, readers usually get involved after the fact, as critics and analysts; at OpenFile, they are active before the fact, as assignment editors.

A similar story is that of Rachel Sterne, who founded GroundReport in 2005, with the idea that she could create a Web site that would be open source and linked to citizen journalists around the world, and edited by experienced volunteers. With Sterne's vision, the first thing to go is objectivity. "Bias is what citizen journalists do well," she told the New York Review of Ideas. "It puts a more human face on things" (Iquateman, 2009). The site bills itself as "a not-for-profit open news platform providing amateur, apprentice and professional journalists with the digital tools required to reach a local or global audience" (groundreport.com). Its home page features two tabs: "Get News" and "Post." Stories are wikis, organic collections of tweets, quotes, addendums and updates from multiple authors, and can make for some compelling reading. For example, a report of an Israeli Tour bus coming under attack in Bulgaria, reads, in part, as:

Bulgaria: Israeli Tourist Bus Attacked 
by Global Voices July 19, 2012

By Gilad Lotan

At least seven people were killed in an attack against Israeli youth ${ }^{[1]}$ on a tour bus in Burgus Airport in Bulgaria.

UPDATE: @BarakRavid ${ }^{[3]}$.

Bulgarian FM spoke with FM Lieberman and told him the investigation found the explosion was caused by a bomb hidden in the trunk of the bus

Israeli Prime Minister Bibi Netanyahu stated that "all signs point to Iran" ${ }^{[4]}$ and that Israel will respond fiercely.

Shoshi, Israeli who witnessed the blast said ${ }^{[5]}$.

We passed immigration and got onto bus \#4 outside the airport. We placed our bags, and after two minutes bus \#2 went up in flames. We were evacuated into a secure room. (groundreport.com, 2012)

The result is that the audience is reading a story as it is being assembled. This can be rough, sometimes barely coherent and not entirely trustworthy. But the idea is that the audience is in on the process and, therefore, understands that the truth will unfold as errors are corrected and contradictions resolved. This form of story telling, by the way, is something anyone can do, thanks to an application called Storify. It allows anyone to pull together news-story excerpts, photos, tweets, even videos, and incorporate them with links into their own running commentary (storify.com).

Newspapers have always tried to feature some sort of reader involvement, at least since the 18 th century, when British papers would leave a blank fourth page, where a reader could write comments before folding the paper and mailing it on like a letter (Wiles, 1965, cited in Hermida, 2011: 13). Every modern newspaper has a "Letters to the Editor" section of its op-ed page. Many welcome contributions from readers, and have 
spaces set aside for personal essays, opinion pieces and reminiscences. In the 1970s, there was even a publication that was mostly written by its readers: Harper's Weekly: A Journal of Civilization. It was an offshoot of Harper's magazine and it took its title from a political weekly that was published from 1857 to 1916 . It came out biweekly, and it was not a success. In those days, a reader had to sit at a typewriter, compose a story, put it in the mail with a cover letter, wait to see if it would be accepted, and then wait weeks to see it in print. With the Internet, you bang out a few paragraphs, hit "send" and wait a day or so for it to pass the moderator, if there is one.

So, the challenge for newspapers today, is to engage "a user who is at once switched $[s i c]$ and switched off, engaged and complacent, informed and ignorant, increasingly reliant on journalism and inclined to bypass journalism altogether. No small task indeed" (Deuze, 2004: 147). As with all the new applications of communication technology, there are evangelists and skeptics, and not a lot in between. And this brings us back, as always, to Dewey and Lippmann. The evangelists imagine an audience of politically aware citizens just dying to involve themselves in the public discourse, while the skeptics argue that online living has, if anything, left us even less time to be omnicompetent citizens.

One phenomenon points to the ways in which this delusion of universally involved citizenry might open the door to the cheapjack and the opportunist: the Internet troll and its various mutations. Almost any story, video or comment that goes up on the Web that allows for user involvement is subject to remarks ranging from the stupid and juvenile to the hateful and the vicious. "The protective force field of anonymity - or pseudonymity - brings out the worst in some people. They say things they would never 
say in the presence of flesh-and-blood human beings" (Seitz, 2010). Even in this case, there are those that argue that there is value to even the lowest form of contribution, because it shows us the human subconscious "in all its snaggletoothed, pustulent glory, with a transparency that didn't exist before the Internet. And in a rather twisted way, that's a public service" (ibid.). In other words, it's better that the poison be out steaming in the sun than festering in the dark. And there are others who argue that, unpredictable and potentially destructive as it is, the protective shield of anonymity may be necessary, because it also allows people to make comments that might get them in trouble with people in authority. Therefore, online, it may be even more important to "court the abyss," and tolerate the loathsome to protect free speech, (Peters, 2005). Suffering the vile and the stupid are the price we must pay for protecting the unnamed source and, when you consider that some very big stories have been pried loose with the help of unnamed sources - Watergate being the most famous - it is easy to understand why some journalists are unwilling to take anonymity away from their readers.

The popularity of comments can highlight the characteristics of successful journalist-audience collaboration. For users, they offer the immediate satisfaction of getting published and having a part in the day's agenda, without demanding a lot of involvement or creativity to produce; users posting a comment do not even have the burden of finding their own topic. From the journalist's perspective, comments can be ego-gratifying. Unlike other user contributions, comments leave the journalist in the traditional position of the lead singer, while the audience members generally play the minor, faceless and reactive role of the chorus (Reich, 2011: 98).

There are good reasons newspapers keep, and many journalists like, comments fields. As Reich points out, they do little to challenge the traditional roles of the reporter and editor while giving the illusion of a discourse, and they occasionally provide useful 
leads and trains of thought for reporters and editors - at least the open-minded ones - to follow, or bounce off. Comments fields also absorb resources, because they need to be vetted by a moderator before publication, to deal with issues of profanity, libel, slander and malice. Other areas of contention "include their low quality, uncertain origins and frequently dubious contribution to the public discourse" (ibid.). As well as using moderators to vet comments, some newspapers are moving away from a totally anonymous free-for-all. For example, most newspaper sites require users to set up a profile and sign in before posting a comment - thus allowing the user anonymity to the public, but having a name and address for the moderator. In Canada, for example, the Postmedia papers, the Globe and Mail and Toronto Star all require users to sign in before posting comments or suggestions (canada.com, thestar.com, theglobeandmail.com). "If anonymity has what academics call a 'disinhibition effect,' registration goes a long way to counter it ... in essence creating what might be termed a 'reinhibition effect' " (Reich, 2011: 109).

Moderation also allows newspapers sites to keep track of people who are responsible for multiple postings - and that brings us back to Raymond Williams's cheapjacks. One thing that was quickly discovered about the Internet and its anonymity is how easy it can be to skew or hijack polls and conversations. It's not difficult to create the illusion of controversy or even consensus online simply by stacking an online poll, debate or comments field with the kinds of results you wish to see. There's even a word for it: "freeping." The Ethics Scoreboard Web site defines freeping as "coordinating efforts to overwhelm online polls with thousands of silly, obscene, irrelevant or politically pointed responses. The name comes from Free Republic, a politically 
conservative activist website that has a readership especially responsive to poll sabotage requests" (ethicsscoreboard.com /list/freeping.html). CBC News Network found itself on the receiving end of an organized freep in 2008, when it connected itself to Facebook and the youth group Student Vote, to ask the question: "What is your wish for Canada in the coming years?" The network's Paul Hambleton told a BBC seminar that it was only about a week before "two interest groups began freeping the site" one pro- and the other anti-abortion.

Our idealistic and motivated contributors lasted but a few minutes in the sea of abortion rhetoric. In the end, the top two wishes for a better Canada were a nation that supports abortion and one that opposes it. Other more genuine ideas wound up buried in the vitriol of the abortion debate. Why? Because without moderation the wisdom of the masses naturally descends to a common denominator that is determined by those with the most time on their hands. Free expression is not terribly compassionate (Hambleton, 2009: 36).

And that raises an economic point: publishers who believe that "digital first" is a way to cut costs by unloading work onto the readers haven't thought things through. It takes constant attention to keep comments threads, forums and polls from turning into the playthings of the nuts and obsessives, and those with an agenda. Plus, many of the more interesting possibilities of participatory journalism may actually create work. First, there's the obvious point that it is futile and perhaps legally suicidal to allow readers' comments to go up without moderation, and a simple software filter for objectionable language won't do the job. Second, the more interesting participatory journalism experiments require participation on both ends.

THERE IS a tendency for journalists to cling to their roles as "gatekeepers." And to a large extent, buttons for "emailing," "tweeting and "liking" create the illusion of 
participation, as do the quotes from readers (little more than a glorified person-in-thestreet column) and the boxes listing the most liked, commented and tweeted stories. Even user-comment fields are little more than "symbolic participatory spaces" (Reich, 2011: 99), because they are "adopted more widely as listening devices than as devices for dialogue between journalists and audiences" (Hermida, 2011: 181). If the news sites aren't reading them, responding to them and acting on them, they're little more than window dressing. And, often, when user participation is applied in a more active sense, it is because publishers have dollar signs flashing in their eyes. Invitations to "be the reporter" or "send us your pictures" are a come-on to "a highly exploitive use of the medium" in which newspapers "entice citizens wearing their 'website users' hats to contribute unpaid labor ..." (Vujnovic, 201 1: 146). However, in its more serious manifestations, user participation should demand a higher level of involvement from journalists. If readers are simply supplying cute pictures of cats or pretty, snow-laden backyard decks, or reminiscences of their 10th birthday, little professional involvement is required, beyond cropping a picture or straightening out some grammar and syntax. At the same time, little is accomplished that couldn't have been done with old technology. Understandably, many journalists, having seen waves of layoffs and cutbacks, regard participatory journalism mainly as another threat to their jobs. Typical is Paul Carr's reaction to a plan by Forbes magazine to turn editors into "curators of talent" for reader contributions: "My conclusion was that, in the Internet world, quality, originality and exclusivity are fast becoming irrelevant. Instead, online publications increasingly treat content as low-paid, illiterate swill, commissioned by the ton to provide SEO [search-engine optimization] and inventory" 
(2010).

Done ambitiously and with an eye to enhancing the scope and reach of journalism, user participation should mean more staff, not less, and better reporting, not "illiterate swill." As Shirky put it, "The current change, in one sentence, is this: most of the barriers to group action have collapsed, and without those barriers, we are free to explore new ways of gathering together and getting things done" (2008: 22). Thus, some newspapers are experimenting with training sessions for readers who want to get involved, to familiarize them with some of the journalistic conventions and legalities of contributing to a site (Singer, 2011: 136). Others have taken to assigning community editors, coordinators or coaches to work with readers' comments, neighbourhood reporting and blogs linked to their sites; in some cases, user-generated comment is contained in a subsidiary site, and connected to the professional site (Paulussen, 2011; Domingo, 2011). For a little less than two years, the New York Times partnered with the City University of New York to create "collaborative, citizen-based, local journalism" in which two professors and 10 students from CUNY set out to find a way in which Brooklyn could "report on itself" (Myers, 2010). It organized a similar plan with New York University to cover the East Village of Manhattan (Pompeo: 2012). The Times discontinued the two programs in June 2012: "The sites ceased to be a priority for a news organization with no shortage of priorities, including a growing list of new web initiatives that have been rolling out as readers continue to adapt to the paid digital model implemented by the Times last year" (ibid.). The Times statement indicated that the paper had learned what it could from the experiment and was moving on to new projects (ibid.). 
At the Guardian, there is a permanent "head of communities," a job that is "primarily regarded as a strategic role ...

"It's quite a senior position," one of the editors explained. The person not only oversees a team of in-house moderators but also develops strategies for creating a "much greater sense of communities across the site" and looks for partnerships and technological solutions to keep on top of the flood of user generated content (Paulussen, 2011: 67).

It's clear that there is a role for readers to play in contributing hyper-local content, blogging, creating and maintaining a conversation about the culture, and simply prompting journalists to ask the questions that matter to their audience. And, in a world where journalists are becoming more and more desk-bound by the demands placed on them by reduced staffing, widening responsibilities and more emphasis on computer-assisted reporting, there is obvious value to having eyes and ears on the street.

This means journalists have to be open to the idea of crowd-sourcing, which uses the Internet, Twitter and social media to expand and accelerate the reach of reporters beyond anything they could have imagined a decade ago. In a talk at TED in 2011, Guardian reporter (and now special projects editor) Paul Lewis explained how he used Twitter to research two pieces of accountability journalism: the first dealt with allegations that news vendor Ian Tomlinson had been killed by London Police in an unprovoked attack during the protests at the 2009 G-20 summit; the second involved Jimmy Mubenga, a political refugee who died while being deported from Britain to Angola. In the latter case, the official story was that Mubenga had suddenly taken ill on the flight. The true story was that three security guards more or less suffocated him while trying to restrain him. In both instances, the official version of 
the story was debunked by citizens who came forward after Guardian journalists put out calls, via Twitter and the Internet, for witnesses. In the first case, the calls produced cell phone video that showed London Police shoving Tomlinson to the ground and attacking him. In the second, the Guardian posted highly speculative stories designed to provoke controversy and comment, and put out a call via Twitter, which produced an American working on an Angolan oilfield, who was on the flight with Mubenga and witnessed his death (Lewis, 2011). In neither case would the stories have been reported without citizen involvement. Lewis says this sort of story cannot be written without journalists accepting that they "can't know everything, and allowing other people through technology to be your eyes and your ears. And ... for other members of the public, it can mean not just being the passive consumers of news but also co-producing news" (ibid.).

As Deuze points out, this is, perhaps, the culmination of the civic (or public) journalism movement of the 1990s and early 2000s, and that Public Journalism was an idea in need of technology to make it work.

Civic journalism as such is sometimes characterized by three steps: it reformulates the relationship between the press and the people, it emphasizes establishing connections and contacts between journalists and the communities they cover trying to address the audience as equal partners instead of 'just' consumers, and finally it emphasizes a focus on issues instead of institutions (summery from Dahlgren, 1998). Although this last item may not be typical of online journalism, the first two points could come straight out of a handbook of 'how to do online journalism' $(1999,385-386)$.

IT IS A short step from civic journalism to citizen journalism, and from the press involving the user to the user involving the press. A lot of modern reporting-both 
spot and investigative-is being done by people with no professional training, who simply feel the need to bear witness. The Arab Spring uprisings of 2011, and the ensuing civil wars in Libya and Syria were, to a large extent, reported with cell phone, Twitter and Skype. Sometimes, citizens were taking pictures with cell phones alongside professional photographers and videographers with expensive equipment. Sometimes, there were only people with cell phones to record a tragedy, or atrocity. Occasionally, the people with the cell phones have even found themselves covering the deaths of the journalists with whom they have been working.

Citizens have been providing images and bearing witness for journalists as long as there have been pads, pencils and cameras, and some iconic works of photojournalism are the work of amateurs. The famous shot of a woman grieving over the body of a dead protestor at Kent State University in 1970 was shot by a photography student taking a break from his work; the horrific photos of the crash of an American Airlines DC-10 after losing an engine in Chicago in 1979 were taken by a bystander at O'Hare Airport; the video of Rodney King being beaten by Los Angeles Police in 1991 was captured by someone with a home video camera on a nearby balcony. Perhaps most famously, the most powerful footage of the John F. Kennedy assassination was taken on a home-movie camera by Abraham Zapruder, a Dallas citizen who happened to be in the right place at the right time, filming Kennedy's motorcade as it passed through Dealey Plaza on Nov. 22, 1963. All are pre-Internet, and pre-digital. Yet, the revelation that police at the University of California at Davis pepper sprayed peaceful protestors in 2011 fits into this continuum: onlookers filmed the event with their cell phone cameras. However, 
rather than go to the media, the footage was posted on YouTube, where it contradicted the University's version of events: that the police had been forced to use pepper spray. Then, the media picked up on it and eventually the university president was forced to apologize. The situation highlights the fact that "police and government ... seemingly cannot get their heads around a simple enough concept that wherever one is, someone is watching and recording" (Whittaker, 2011). What digital technology and the Internet have enabled people to do is go directly to the audience without passing through the media, and to do it with a speed the news media can rarely match.

For example, there hasn't been a U.S. war covered by a completely independent media since Vietnam. During the Gulf War, reporters covered combat from a distance, getting their information from daily military briefings, and the situation has been, more or less, the same in Afghanistan, though reporters have been allowed to accompany military on patrols. Similarly, the War in Iraq started out to be perhaps the most heavily mediated and controlled military adventure in U.S. history, with reporters going into action "embedded" with military, who were responsible for them, and to whom they were responsible. But, once the United Sates was in control of the country, bloggers inside the military almost immediately began to use the Internet to circumvent military censorship. The abuses at Abu Ghraib prison were reported largely because a group of U.S. soldiers took pictures with digital cameras and then posted them on the Internet. In the same way, a few dozen military personnel with laptops went online and created an instant Iraqi War literature. Wired magazine describes this "oddball online Greek chorus narrating the conflict in Iraq." 
It includes a core group of about 100 regulars and hundreds more loosely organized activists, angry contrarians, jolly testosterone fuckups, self-appointed pundits, and would-be poets who call themselves milbloggers, as in military bloggers. Whether posting from inside Iraq on active duty, from noncombat bases around the world, or even from their neighborhoods back home after being dischargedwhere they can still follow events closely and deliver their often blunt opinions-milbloggers offer an unprecedented real-time real-life window on war and the people who wage it. Their collective voice competes with and occasionally undermines the DOD's elaborate message machine and the much-loathed mainstream media, usually dismissed as MSM (Hockenberry, 2005).

It was only a matter of time before an organization sprang up to facilitate this sort of information-leak reporting. (Calling it "investigative" is misleading, because there is very little investigation involved. Rather, what Wikileaks does-and indeed what much "investigative" reporting involves - is to receive information and pass it along.) Wikileaks was founded in 2007 and, since then, "has published scores of documents never intended for public view, and its professed ability to safeguard the security of those who wish to publicize such documents has meant that the site has become an important destination both for leakers and interested citizens. It has also become a destination for journalists, who have covered newsworthy leaks ..." (Lynch, 2010: 309). That involved such things as leaking Sarah Palin's email, revealing the inner workings of Scientology, and publishing protocols from Guantánamo Bay. In 2010, however, Wikileaks' went high-tech, and high profile, when it took possession of a massive, encrypted video file, and then put out a call for a super-computer to decrypt it. What it found under the encryption was a sensational video of U.S. helicopter troops firing at civilians on the ground in Baghdad. The video ran 38 minutes and ended with 12 people dead, including two employees of 
Reuters. Wikileaks also posted an edited 17-minute version of the video, which was more widely seen because it was posted on YouTube, and was criticized for not explaining that the attack took place as part of a series of skirmishes and that one of the targets had been carrying a rocket-propelled grenade (Cohen \& Stelter, 2010). As for the process of decrypting the video, the organization was simply doing what the news media should be, said Wikileaks co-founder Julian Assange: "That's arguably what spy agencies do-high-tech investigative journalism. It's time the media upgraded its capabilities along those lines" (ibid.). Wikileaks has been criticized as often as it has been praised, mainly for its attitude towards the ethics and morality of its actions - that is, it has none. Wikileaks' approach is not to ask questions about the origins of its material, and then to publish and be damned.

Wikileaks comes up only infrequently in conversations about innovative efforts to reinvigorate journalism. Though one can make the claim that Wikileaks' pushing of legal and ethical norms makes it marginal to such conversations, it is equally true to say that Wikileaks is unsettling to journalists because it represents a radical shift in the way information is collected and distributed in the media landscape. The site is one of the best existing examples of a phenomenon described by Yoachi Benkler in The Wealth of Networks (2006) - the emergence of a critical information media that is indebted neither to states nor markets (Lynch, 2010: 310).

Perhaps the most vivid recent examples of how citizen journalism can fill in the gaps in our experience come from the civil wars in Syria and Libya. Almost daily, the Western news networks carry images of bombing, strafing and shelling, and of shattered buildings, broken bodies and grieving, enraged or victorious civilians. This sort of information flow belongs entirely to insurgents - since official sources have official ways of disseminating information - and is, therefore, understandably biased 
and one-sided. Often, however, the setting of a story may be so dangerous or remote that the only way to get information is to pick it off the Internet, to which it has been uploaded by citizens with cell phones and cameras who are living the story as they report it. For example, though there have been professional reporters covering the insurrection in Syria, they have mostly been working beside citizen journalists, sometimes to tragic and surreal effect. Take the instance of U.S. reporter Marie Colvin and French photographer Rémi Ocklik, who were killed in the Syrian government shelling of Baba Amr in February 2012. They had been working alongside Syrian Khaled Abu Salah, the spokesman for the Revolution Leadership Council of Homs. Just a few days earlier, they had reported on him. After the shelling, he was reporting their deaths, via cell phone camera:

Within an hour, his video report would be posted on YouTube, and then picked up by networks around the world. "They were killed because of the random shelling of the Baba Amr neighborhood," Mr. Salah said, angrily shaking the forefinger of one good hand at the camera; his other hand, wounded by shrapnel, was bandaged. "This is a call to save the remaining residents while they are still alive" (Nordland, 2012).

Citizen journalism has proved particularly effective and valuable in times of natural disaster, too. When an earthquake rocked the city of Christchurch, N.Z., in February 2011, much of the public service communication and the news reporting came via user-generated content, helping people locate loved ones, publicizing distribution points for supplies, and getting out the story of what was happening. Similarly, most of the close-up video of the catastrophic tsunami that followed the Tohoku earthquake in Japan, a month later, came from people on the ground who felt compelled to record what they were trying to survive. 
In a disaster UGC [user-generated content] is not here for your entertainment. It is not competing with network news for ad dollars. It does not care whether it should be pitted against professionals or win a journalism award. It is a way for people experiencing the most significant event of their lives to bear witness, to cry out their pain and their suffering and their need, to connect with people close by who are sharing their experience and to connect with people far away who, but for their voices, might mistake these events for a blockbuster movie on a soundstage (Colbin, 2011).

There's even an app for that. As well as providing organizing and communication tools for civil resistance, such as the anti-globalization protests and the Arab Spring uprisings, social networks like Twitter and Facebook keep us up to date on local and world events. This kind of citizen journalism is what inspired Mark Malkoun, of Lebanon, to create an app called Signal (Ortiz, 2012). The app has been renamed Completure and promises to enable anyone to "[c/reate a mini-story in seconds using photos, geo-location, and a short title about real-world events" (Completure.com). As of July 2012, it was extremely hard to get a look at, because it was only available in beta form, and one had to request an invitation to try it out (ibid.).

Of course, there are dangers to the amount of information being gathered, and the speed with which it becomes part of the public discourse. For example, the gruesome footage of the murder of deposed Libyan leader Muammar Gaddafi was splashed across the Internet by Libyans with cell phones almost as fast as it was taken, disproving reports that he had died in combat. Whether we should take such images at face value, however, is doubtful. As the Poynter Institute's Regina McCoombs told Global Post: "I don't think they answer any questions, but they raise questions and cast doubt on things people say. It's good to have them, but to say they 
prove or disprove anything is a stretch" (Lodish, 2011). With the Gadaffi killing, the truth suited the citizen journalists' agenda, so they were disseminating it to counter false reports. Sometimes, doctoring the truth can take an innocent form, as with the case of a Syrian citizen journalist in Homs, who added smoke to a backdrop of a report to increase its dramatic effect (Flock, 2012). However, it does imply a willingness to bend the facts to fit the agenda. And there are citizen journalists who see nothing wrong with breaking the law or practising entrapment to forward their agenda: for example, "conservative gotcha artist" (Meek, 2010) James O'Keefefamous for posing as a pimp to ensnare ACORN officials by filming them advising a "prostitute" to game the system. In January, 2010, he was arrested for tapping the phones of Louisiana Democrat Mary Landrieu (ibid.). As Rachel Sterne said, "bias is what citizen journalists do well."

With YouTube, they have a worldwide arena for their work, though it's one that is just beginning to feel its strength. The Pew Center's Project for Excellence in Journalism took a tally of the most popular YouTube videos in 2011 and not surprisingly, music dominated seven of the months, with Lady Gaga taking two months, and the other five belonging to Drake, Katy Perry, Rock in Rio, Taylor Swift and Amy Winehouse (the "Rehab" video spiked after her death). Three others belonged to a video game, the death of motorcycle racer Marco Simoncelli, and a homeless man with a powerful voice. Only two months were dominated by news: March, with the Japanese Tsunami, and May, with the death of Osama bin Laden (PEJ, 2012). However, the popularity of the 30-minute video "Kony 2012," about the Ugandan warlord Joseph Kony, indicates that there is an appetite for current events 
among young people. It was viewed an average 7.6 million times a day for the first 10 days after it was posted on YouTube, and 125,00 times a day over the following four months (ibid.). Another Pew Center study showed that the Kony video revealed that younger people tend to get more news from You Tube than older people do. Those aged 18 to 29 were much more likely than older adults to have heard about Kony and his Lords Resistance Army through the video, and to have learned about it through social media such as Facebook and Twitter (Rainie et al., 2012)-which has interesting implications for the site as a future news source. Amy Mitchell of Pew's Project for Excellence in Journalism told the Globe and Mail:

There's a new form of video journalism on this platform. It's a form in which the relationship between news organizations and citizens is more dynamic and more multiverse than we've seen in most other platforms before (Coyle, 2012).

These are manifestation of what may evolve into an entirely new way of collecting, processing and disseminating journalism that involves an ever mutating and shifting network of connections and affiliations partially dependent on media such as Twitter and Facebook to call attention to itself. That also would imply that the most important role of traditional media might be to play moderator, facilitator, truth detector and publicist for this organic newsgathering network. In the future, the major duty of journalism may come to be watching the flow of information and opinion, harvesting the best of it, and trying to assure something important doesn't go unnoticed and that lies don't permeate the public record. As Lewis pointed out, this involves journalists admitting that they can't be everywhere, and allowing their sources to take on a much more active role in bearing witness to the world around them. Again, the difference lies in the timing. Traditionally, sources came in after the 
fact, and were sought out by journalists asking, "What happened?" Sources today witness something and put it out for the world to see, and the journalist comes by after the fact to try to verify and make sense of what happened.

By way of comparison to the old way of getting out stories that need to be told, the New York Times talked to Daniel Elsberg, a RAND corporation analyst, who in 1971 gave the Times the Pentagon Papers, a secret report calling into question the U.S. involvement in Vietnam. How would he handle the documents today? the Times asked.

"I would have gotten a scanner and put them on the Internet," Elsberg replied (Cohen, 2010).

THE MAINSTREAM news media are more than aware of the existence and uses of social media, but the compulsion of some broadcasters to mention it at least twice in every news report they air indicates little more than a slightly sad need to appear cool for the youngsters. In 2009, Forbes described the role of "social media director" as "journalism's hottest job," and talked about tweets being the "gold standard of scoops" (Smilie, 2009c). As the article mentioned, there's one small problem with this type of thinking: it accomplishes nothing for the news organization, beyond awarding bragging rights for being first with the least. Since then, many news organizations have come to understand that Twitter is an extremely effective tool for promotion and information gathering but, for story-telling, it leaves something to be desired. However, matched with a good editor, tweets can be collected into something compelling, and in the hands of a skilled headline writer they can be used as a 
powerful draw to the main event, both as a brand builder and as a driver of traffic. A $2011 \mathrm{HP}$ labs study revealed that mainstream news outlets, and not bloggers, are the main drivers of Twitter trends. It also revealed that Twitter trends usually don't last longer than 40 minutes. What kept an issue alive was the incidence of retweets; it was the more substantial topics that tended to generate the most conversation, and these came from news outlets (Diana, 2011). And, as we saw with Paul Lewis's case studies and the incidence of citizen journalists tweeting events as they happen, the other and probably more important use for Twitter is as a way to gather information and to tap into the public discourse.

One of the fascinating things about Twitter is the pattern of flow of information is unlike anything we've ever seen before. We don't really understand it. But once you let go of a piece of information, it travels like wind. You can't determine where it ends up but, strangely, tweets have an uncanny ability to reach their intended destination (Lewis, 2011).

That other social media monolith, Facebook, is also coming into focus as a tool to promote journalism. A 2011 Pew Research Centre study revealed that Facebook was the second or third most important driver of traffic to news sites such as the New York Times, the Washington Post, ABC, CBS and Fox news, CNN and the Huffington Post (Pew, 2011). This ties in with studies showing that search engine optimization-throwing every keyword you can think of into a headline to get it to pop up on Google-is much less useful than brand building. Many newspapers are finding Facebook a valuable brandbuilding tool and that, when it drives traffic, it brings in readers who "tend to view more articles and stay around a site longer" (Grueskin et. al., 2011: 32). For example, Mashable.com found that Facebook and Twitter visitors spent 29 percent more time at the 
site and viewed 20 percent more material than visitors arriving by search engine (ibid).

With roughly 500 million users worldwide, Facebook's audience is vastly larger than any single news organization. Its role has evolved from a network for friends to share personal information to a way for people to share, recommend and link together all kinds of information, including news. If searching for news was the most important development of the last decade, sharing news may be among the most important of the next (Pew, 2011).

IF THERE is one technological bane of the newspapers it is-at least in their minds-the aggregator. And if there is one technological tool that carries most of the hopes and dreams of newspapers publishers, it would have to be the tablet.

Aggregators have been called parasites, thieves and opportunists. When Michael Wolff told Rupert Murdoch that he helped found the aggregator Newser, Murdoch's response was, "So you steal from me" (Wolff, 2009). Former Washington Post executive editor Leonard Downie described aggregators as "parasites living off journalism produced by others" (Robinson, 2010). Internet billionaire Mark Cuban told Newsweek that the newspapers sites should "kill off these parasites" by using a few lines of media code that blocks incoming links from aggregators, so they lose their Internet news-guide status (Lyons, 2009). Even Comedy Central's fake TV pundit Stephen Colbert got into the discussion in 2011 by striking back at the Huffington Post for cannibalizing his Web site. He did this by launching the "Colbuffington Re-Post," a reposting of HuffPo's reposting of Colbert's original material (McGlynn, 2011). In a further dig at Arianna Huffington-who sold her site to AOL for $\$ 315$ million in 2011 (Adams, 2011)-Colbert immediately put his "site" up for sale for $\$ 316$ million (McGlynn, 2011), and then had Huffington onto his show to talk about it. There's no doubt Huffington Post is the King Kong of aggregators. Founded by Huffington, Kenneth Lerer, Andrew Breitbart and 
Johnah Peretti in 2005, this thing came from nowhere to more or less dominate the world of aggregation in less than five years. Today, it "boasts 68 sections, three international editions (with more to come), 1.2 billion monthly page views and 54 million comments in the past year alone" (Shapiro, 2012). Huffington has been criticized for doing it on the backs of news-gathering organizations and a stable of bloggers who write for her, for free. "Our bloggers come and go," she says. "They write when the spirit moves them, and they do it because they want to be part of the conversation" (Dumenco, 2009). To be fair to Huffington, that's exactly the kind of reasoning newspapers have used for years to rationalize things like unpaid internships and freelance "opportunities" that pay less than the cost of lunch at McDonald's. To further sharpen the point that journalists really hate aggregators, the Washington Post's Ian Shapiro compared the time he put in on a story, roughly two days, and the time a Gawker writer put in to scalp it: "Probably took me, you know ... a half an hour to an hour" (Shapiro, 2009). The aggregators reply that they're friends to the newspapers, that by driving traffic to the newspapers sites they boost the profile of the originators, which is hard to prove without asking the readers of every newspaper how they came to their level of brand consciousness.

In a perfect world, the tablet would have been invented before the Worldwide Web, and newspaper publishers would have had their dreams come true in one neat, paper-thin, eight-by-11-inch package of plastic, aluminum, glass and magic. The allure of the tablet is obvious: it appears to offer newspaper publishers the chance to achieve their dreams of a newspaper without the cost of ink, paper or distribution, and without giving up the proprietary information that enables them to gather customers for advertisers. "I think it's a case of when you are a drowning man, everything looks like a lifesaver," is 
the way New York Times media critic David Carr put it when he was moderating a panel on tablets and newspapers (Jackson, 2010). However, there's no denying the allure of the device, and there are those that hail it as the real saviour technology. The apps that it runs (or run it) have more in common with software or video games than with a Web site, in that they are non-physical objects that carry the consumer appeal of a physical ones. You have to buy an app and load it onto your device and, once it is there, the company that sold it to you can use it as a conduit to more delights for the consumer and, hopefully, more income for the seller. "The experience of reading a magazine-or a newspaperon one of these mobile devices is in many ways superior to the experience of reading the printed product. ... Advertisers can only exult in the visual quality of the ads, as well as the touch-through capabilities to route interested readers to more detailed formation on products" (Dornan, 2012: 74).

When Newsday unveiled its iPad app in the Fall of 2010, it did so with a commercial that could have been titled "Happy Days Are Here Again." It showed a man having breakfast with his family, and reading Newsday on his iPad. "The new Newsday app is better than paper in all kinds of ways," the announcer says, while the man looks up from his paper at a fly buzzing around the table. Then, "SMASH!" the man flattens the fly, leaving pieces of glass all over the table, and scaring the daylights out of his family. "Except for one. Get Newsday, in a whole new way. Every day," the announcer says, as the man picks up pieces of glass.

(youtube.com/watch?v=Rtdq87nX6EA\&feature=-related, 2010).

The message is clear: we can forget about that troublesome, disorganized Internet, and throw away our newspapers, but we can still go back to the way things 
used to be. Even the close-ups of the iPad as the man reads it make it clear that this is an enhanced newspaper experience. He scrolls. He turns the thing from portrait to landscape perspective. He enlarges pictures. In other words, he does exactly the kinds of things people do with newspapers. And, to hammer home the point, he gets so immersed in the experience, he tries to swat a fly with it: "the same pages turning, the same staffing structures, the same reporting remit and revenue routines, but this time on a screen in your briefcase or handbag" (Preston, 2011).

If you need further proof of the newspaper business's enthusiasm for tablets, consider that even Rupert Murdoch likes them. In fact, he liked them before they existed. In May 2009, in an interview with his Fox News network, he predicted that inside two years, "you may get [the newspaper] on a panel which would be mobile, which will receive the whole newspaper over the air, be updated every hour or two. You'll be able to get the guts or the main headlines and alerts and everything on your Blackberry, on your Palm or whatever, all day long" (Agence France-Presse, 2009). Roughly a year later, after Apple had finally unveiled its iPad, and companies such as Samsung, Sony and RIM were scrambling to catch up, Murdoch announced plans to start a new newspaper dedicated to the device. Nothing you could swat a fly with; just glass, aluminum and magic. Rumors were circulating about high-priced talent being hired and big-name freelancers being contacted. Murdoch told his news network that his "No. 1 most exciting project" was the Daily (Pompeo, 2010c). Murdoch launched the Daily, in February 2011 , with the declaration that the news business had "to completely reimagine our craft" (Gustin, 2011). It was unveiled at a press conference with Apple's vice-president of Internet services, and part of the announcement 
included a detailed description of its terms of service, and the fact that it would allow one-click subscriptions, and was available for either $\$ 1$ a week or $\$ 40$ a year (ibid.).

Six months later, Apple announced the licensing of app No. 500,000-roughly 14 months after the company had launched the iPad itself. At that time, only three percent of the apps were news, compared to 15 percent games, 14 percent books and 11 percent general entertainment (Preston, 2011), implying that the Phantom Public is alive and well, and haunting the digital world. One of the top U.S. app designers complained that the mistake publishers were making was to try to replicate the newspaper experience digitally. "They have to reinvent, not redesign," he said" (ibid.). By the summer of 2012 , the Daily was losing $\$ 30$ million per year, and had reportedly been put "on watch"- that its continued existence would be re-evaluated after the U.S. presidential election in November (Stoeffel, 2012). That's not to say there is no future for newspapers with tablets and e-readers such as Kindle, Skiff and Kobo. But the belief that aggregators wouldn't colonize these devices was a bit naive. It took a little more than four months for Flipboard to come along. Advertised as "the world's first personalized, social magazine," it culls information from a variety of sources and, as $P C$ World puts it, combines them "into an attractive, remarkably intuitive layout that closely duplicates the look and feel of a print publication'." The magazine also calls the app "Rupert Murdoch's nightmare" (Wilson, 2010).

Two years later, the Top 10 titles available through Apple's Newsstand app are: The New York Times, The Daily, New Yorker, Men's Health, National Geographic, Cosmopolitan, GQ, O The Oprah Magazine, Popular Science and

\footnotetext{
${ }^{1} \mathrm{My}$ italics.
} 
Consumer Reports. Only two are newspaper (in fact, they're the only two in the Top 20 ), and one of these is losing $\$ 30$ million per year. Of the rest of the Top 20 , 10 deal with health, fitness, beauty or other forms of self-help, three are general interest magazines, two are science magazines, one is the always indispensible Consumer Reports and one is a high-tech magazine (Botelho, 2012). To be fair, local newspapers are never going to register on surveys such as this and will probably take years to make the transition from print to tablet. One positive sign is that, in 2011 , the Pew Centre's Project for Excellence in Journalism found: 27 percent of Americans were getting their news on smart phones and tablets; traditional news companies were holding their ground, and still providing most of the news being read digitally; unique visits to online news sites were continuing to grow, up 17 percent over 2010 (Bauder, 2012). In response to the report, there was a note of caution. "I fear the iPad is a siren call to news organizations, seducing them into thinking they can maintain their old models and old controls, not just maintain, but regain them" (ibid.). Unfortunately, as Alan Mutter points out, the newspapers are or the most part staying true to form in their inability to fully exploit handheld devices, by ignoring the potential for using readership data to implement location-targeted local advertising, which could link readers to nearby stores or services as they read the paper on the go. By 2016, advertising sales on the gadgets are expected to rise to some $\$ 7.7$ billion, roughly equal to a third of all ad sales on U.S. newspapers in 2011.

Their efforts are a major threat to newspapers hoping to capitalize on the enviable power of their local franchises to become significant players in the vigorously growing mobile space. Unfortunately, newspapers are woefully behind (Mutter, 2012). 
IF YOU say almost anything good about print, you're made to feel as if you're hollering, "Get a horse" at a passing steam buggy. As Franklin argued, there is a crazy, absolutism in the discourse. It has been defined as print-vs.-Internet and, if you in any way admit there are things about print that you like, you're a bunion on the big toe of progress and likely to start smashing Retina displays if we don't keep an eye on you. Yet, there are all kinds of very technical-minded people who actually like print. For example, Vancouver digital communication strategist and $\mathrm{CBC}$ high-tech commentator Tod Maffin once told me that, as often as he can, he unplugs. He sends out an email telling all his contacts that he'll be out of touch, puts on a pair of pajamas and goes to bed with a book (Interview, 2011). Bill Gates once said in a speech:

Reading off the screen is still vastly inferior to reading off of paper. Even I, who have these expensive screens and fancy myself a pioneer of the Web Lifestyle, when it comes to something over about four or five pages, I print it out and I like to carry it around with me and annotate. And it's quite a hurdle for technology to achieve to match that level of usability (Darnton, 2009: 69)

Neither Gates nor Maffin are preoccupied with appearing cool, and neither has to worry about being in step with the times, because they're generally ahead of them. So, both can freely admit to enjoying the pleasures of print on paper. As Darnton says, our digital fascination appears to have passed through three stages: utopian enthusiasm, in which we expect the world of new technology to accomplish all things; disillusionment when we find out it cannot accomplish all things; pragmatism, when we accept that, even with its limitations, the new technology is still pretty good after all (ibid.). He further talks about past technologies that were expected to be a 
radical improvement over print, such as microfilm and microfiche, which degrade at a much more rapid rate than print and, in some cases, actually make people seasick when they try to read them (a library in Toronto keeps airsickness bags near its readers). And, when we moved material from print to microfilm, we destroyed the print, abandoning a technology that has proved tremendously adaptable and durable for one that was a total flop (2009:112-114).

This is not to say that print will always offer a superior reading experience. Though backlit screens tend to be harsh and hard on the eyes, readers such as Kobo and Kindle are remarkably similar to books and, from an aesthetic standpoint, are easily the equal of a paperback. They will never, however, replace the attraction of a leather-and-gold bound first edition, are unlikely to reproduce the visual splendor of a beautifully printed coffee table book filled with photographs and illustrations, and are, at best, a second-rate way to read a graphic novel. Also, I would venture to add, no tablet is ever going to replace a big, thick Saturday (in Canada) or Sunday (in the United States) newspaper, with its pile of special sections waiting to be spread out on the living room floor and passed around from family member to family member. The New York Times daily edition can be reproduced on iPad, the Sunday Times cannotand if it could, it could not be shared. The thing that makes print "such a perfect delivery vehicle for news" is its graphic design (Manjoo, 2009). One thing we forget in our rush to digital delivery is that there aesthetic sensibilities and conventions that make the newspaper-and magazine and book - valuable as popular culture. Print products are friendly to the eye, comfortable to hold and combine words, pictures and graphic design in ways that are satisfying, occasionally dazzling and often just plain 
fun. And print is a faster technology, when it comes to the way the eye can scan and gather information.

Paper is portable, easy to find, easy to use, and, best of all, skimmable - it lets you glance at several stories at once and read as much or as little as you'd like without getting lost in the weeds (Manjoo, 2009).

In 2009, for example, a San Francisco writer named David Eggers and a "tribe of like-minded San Franciscans" created a 320-page one-shot newspaper called Panorama. It was an old fashioned horse-blanket broadsheet (15 by 22 inches) and sold for $\$ 16$ a copy. It sold out immediately, "foretelling a time when a printed newspaper will be a luxury item, a mass-niche product that many people will pay a great deal of money to get their hands on" (Carr, 2009c). That's likely what the Globe and Mail and New York's Daily News are counting on to cover the costs of their new presses (see Chapter 4). And you can take Maffin and Gates as proof that it is possible for an audience to embrace new technology, and still have a place in its heart for print. Also, it is important to remember that the public is not always fascinated or enthusiastic about the things people in the media are.

We in the media are quick to peddle the newest ideas or technologies, and we forget that our audiences can't or don't want to move that fast. While $96 \%$ of the CBC staff felt that internet news consumption would sky rocket, only $59 \%$ of our audience felt that way. Newspapers? Seventy-six per cent inside our industry felt the print medium is a dying breed, while only $26 \%$ of our audience felt that way. Don't argue with the customer (Hambleton, 2009: 37).

Paper is also quite a bit harder to censor than the Internet. There's no switch you can flick that will shut down all the presses in a country; yet you can do just that with the Internet, as Chinese leadership does with its "Great Firewall." We may find 
that the old-fashioned samizdat may be the best way for dissidents in China and Russia to get around their countries' censorship of the Web.

IN A revolution, "[t]he old stuff gets broken faster than the new stuff is put in its place," and the value, or even the uses of the new stuff aren't always readily apparent (Shirky, 2009a). Consequently, during every major paradigm shift, there is a beginning, where everything is stable and static, and an end point were everything has changed. In between, there is a period in which the old and new coexist even while one is in the process of smashing the other. As Clay Shirky has pointed out in his blog, Elizabeth Eisenstein's examination of The Printing Press as an Agent of Change could almost be used as a guidebook for what we're living through today.

"I venture to say that all great discoveries, all so-called new movements, harbor the same contrasting elements, continuity and radical change" (Eisenstein, 1979: 34). That was written years before the Worldwide Web, and about an upheaval that took place in the 16th century, a period in which the manuscript and the printed book coexisted, while the latter was in the process of demolishing the former. The parallels between the effects of moveable type and of the Internet are as striking as they are obvious:

[P]rinters initially contributed to "advancement of disciplines" less by marketing so-called "new" works than by providing individual readers with access to more ${ }^{2}$ works. The sheer increase in the quantity of copies in circulation was actually of immense significance. Augmented book production altered patterns of consumption; increased output changed the nature of individual intake. The literary diet of a given sixteenthcentury reader ... had been enriched and intellectual ferment had been encouraged, whether he consulted living authors or dead ones, "new" books or "old" ones (ibid.: 169).

\footnotetext{
${ }^{2}$ Her italics.
} 
Eisenstein writes that there was a sense the "swinish multitude" had snatched the implements of enlightenment from the Church, which had perpetuated a "deliberate cultivation of mystery, an insistence on withholding pearls of wisdom" ... (ibid.: 344). There was resistance. Commentators argued that a reading society was less cohesive than a hearing one, that the common person was ill equipped to penetrate the mysteries of the great books, especially in religion, where the learned had a responsibility to unravel the truths for the ignorant. There was fear that a debased literature would erode morals. Now that they could read the "authorities" for themselves, people found ideas often clashed. This undermined trust in institutions, which tried to reassert their control, even though they could no longer contain the flow of information. And, in another parallel with the Internet, erotic novels were among the earliest non-Biblical print output, further shaking the foundations of authority. Lippmann's phantom public and Dewey's Great Community were clashing even then, and in remarkably similar ways to how they clash over gatekeeper and participatory journalism, and "walled garden" vs. Open Web today. As Shirky points out, we mostly look back at the 16 th century and see before and after the printing press, when the really interesting question is, "How did we get from the world before the printing press to the world after it?" (2009a)

At the same time, there are strong precedents for a sort of continuity that, for some reason, the evangelists of the digital age refuse to even consider. Perhaps that is to be expected. As Darnton argues, we always have a tendency to overpraise new technologies and imagine that they will do more to shake the world than they actually do. Every new technology comes with both extravagant promise and moral panic. The printing press, telegraph, telephone, analog television, digital television. All were expected to either 
reduce the populace to a mindless, orgiastic mob, or to enlighten and elevate the masses. As Mosco points out, all were expected, to one degree or another, to bring us to "the end of history, the end of geography and the end of politics" (2003:13). In the end, what we usually get, along with a smattering of social service, is colonization by commerce and a retail mindset in which the most marketable commodities are the fastest to grow-and that often boils down to new ways of delivering distractions and material comforts, such as sex, sports, merchandise and gossip. It's safe to say no medium has ever, on its own, undermined society, or created a new and better species of human.

Darnton writes, "The marvels of communication technology in the present have produced a false consciousness about the past-even a sense that communication has no history, or had nothing of importance to consider before the days of television and the Internet" (2010: 1). That quote comes at the beginning of a book that traces the circulation of anti-royalty poems through 18 th century Paris, by word of mouth and recitals-the social networks of the time. Writing in the New Yorker, Malcolm Gladwell picks up on the parallel between that and the so-called Twitter Revolution in Moldova in 2009 and the strange phenomenon of Iranians tweeting mainly in English about election protests in the same year. Complaining about an "outsized enthusiasm for social media," Gladwell argues: "Innovators tend to be solipsists. They try to cram every stray fact and experience into their new model" (2010). And we can see the evidence of this everywhere, even in the old media, where every tweet or Facebook utterance can be given a weight that seems to ignore the very nature of social media-that it is social. It is informal and doesn't aim to be reliable or even coherent. We confuse chatter with conversation, and cleverness with intelligence. It seems as if commentators are 
competing to see who can come up with the most extreme predictions, from the predictable "print is dead" pronunciations to the sheer craziness of saying that people will stop going to movie theatres because they can watch films on their smart phones.

At the same time, there is a side to the argument-equally predictable and equally limited in its usefulness - that sees every form of new technology as a passing fad that just serves to get in the way of the true mission of the news media, which is to deliver carefully researched, crafted and presented information to a silent, well behaved, waiting audience. Twitter is merely a way for the brainless to tell us what they ate for breakfast; Facebook is a drug for narcissists who want to remain the most popular girl in high school; the Internet breeds short attention spans. In the end, there is a futility in this part of the conversation that is perhaps the only depressing thing about the discourse, a sense that some commentators see it as a campaign to be won or lost, rather than an exchange of ideas. Yet, two things history has taught us is that no new means of communication has ever been put back on the shelf after being unwrapped-and that old ones don't always disappear just because new ones come along.

THE LAST chapter of this thesis looks at the discourse around the subject of craft, taken to include professionalism and art. While the technology has been developing and the business has been shrinking, there has been a fairly vigorous discussion going on about what it means to be in a journalist in this world, and how not just to survive the technological and financial onslaught, but how to make it work for newer and better forms of journalism, as well as how to perpetuate some of the old ways that are worth holding onto. 
ONE OF the recurring themes of the current conversation about the newspaper industry has been the way so much of it has been framed as a battle between light and darkness. The business discussion deals with the "broken business model," the "end of news" or the "death of newspapers." When we talk of technology, it's about old media and new media, sweeping away the gatekeepers and empowering the public - and that is partly where the discussion of the craft of journalism rests: "Throw the bums out!" The converse theme to that is: without newspapers, we lose journalism and, without journalism, we lose democracy. Surrounding all of this, there is an intensity that borders on hysteria, which seems to diminish only slightly as anticipated crises in the craft fail to materialize. For example, at least so far, citizen journalism appears to have failed to deliver the anticipated surge in propaganda and false information. Those things have come, in the form of online activists, flacks, shills and self-styled "gotcha" journalists. However, all those things were there in different forms before the digital age and, if Libya and Syria are any indication, the most noticeable effect of citizen journalism has been to increase the flow of raw information to mainstream journalism and, through crowd-sourcing, to give journalists a reach that is literally thousands of kilometres beyond what they had. Finally, it often seems that these themes have so dominated the conversation that the quieter discourse about the state of the craft, which has been going on since long before there was an Internet, has simply gone away - save for a few atavistic souls who cling to the idea that 
one of the things that might save the news business is better journalism.

Yet, that conversation hasn't gone away. In fact, in some quarters, it has become more urgent. The old complaints remain-about editorial blandness and timidity, creativity-squelching, penny-wise management, and dollar-foolish ownership-like bass notes buried down beneath the piercing highs of financial insolvency and technological determinism. For example, Todd Gitlin argues that there are "five wolves" at the door of U.S. journalism, not just three. Concern about falling circulation, dwindling advertising lineage and increased competition for the public's attention overshadow a severe "crisis of authority" and "journalism's inability or unwillingness to penetrate the veil of obfuscation behind which power conducts its risky business" (2009). Former Vanity Fair and New Yorker editor, and founder of the Daily Beast Tina Brown puts it in earthier terms. At the depths of the recession, when all the focus was on the "broken business model," she wrote:

American newspapers are dying mostly because they were so dull for so long a whole generation gave up on them. They needed to innovate back in the Fax Age of the 1980s but were too self-important and making too much money with their monopolies to acknowledge it. ... It's one of the biggest fibs going that American newspapers are now being forced to give up their commitment to investigative reporting. Most of them gave up long ago as their greedy managements squeezed every cent out of the bottom line and turned their newsrooms into eunuchs. As for the Internet thieving the bona fide reporters' hardworked news stories, "Back at ya!" is all I can say. Online writers for years have had their stories ripped off by newspapers with no credit. At least the Internet links to the things it steals.... (2010).

Brown also points out that "furrow browed" British quality dailies, such as the Times and the Guardian, long ago redesigned themselves to be more colourful and reader friendly, and that they manage to blend " 'sexy' culture coverage and hip 
fashion stories as well as foreign reporting and brainiac columnists that make them a guilty pleasure to read" (ibid).

Canadians - or at least Torontonians - will have some idea of what Brown is talking about: In 1998, Conrad Black founded the right-wing daily the National Post, and gave the paper an almost unlimited budget with which to cause trouble. The editors of the new daily - many of whom had been imported from Britain, where Black owned the Telegraph at the time-brought with them a taste for literary journalism, irreverence, meanness and fun, and a hard-nosed competitive instinct that, for a time, revitalized the national newspaper scene. At about the same time the Post was being founded, in fall of 1998 , the entrenched competition, the staid old Globe and Mail, hired a British publisher named Phillip Crawley, who in turn hired several British journalists, including editor Richard Addis, to brighten up the paper and make it more competitive with the Post-to fight fire with fire. The Post was "|bleautifully laid out and fun to read ... with big, striking photographs, gorgeous women and an airy, modern design ... Silly and smart-ass stories ran on the front page alongside alarmist headlines and columns that boiled the blood of left-leaning readers" (Bell, 2000). The Globe, meanwhile, was a typical, earnest North American newspaper, an "icon of Canadian journalism ... boring and stuffy, which earned it the nickname "the old grey Globe" " (ibid.). By most accounts, the Globe and Mail's British imports antagonized almost everyone-co-workers, readers, even the competition-but they succeeded in moving the paper slightly further to the left, to counter the National Post's rabid right-wing biases, and they made the paper livelier, more interesting and occasionally even surprising, and one that gave as good as it got in the newspaper 
war. There's no doubt that, at that time, the two papers were exactly the kind of lively, thought-provoking "guilty pleasures" Brown wrote about, but it's debatable whether jazzing up the product would have made a difference to Globe circulation absent the competition. One thing is certain: with the dull, responsible Toronto Star and the two battling British clone-papers, for a few short years - until Canwest bought the Post and began slashing the budget-Toronto was arguably the best served newspaper city in North America. Newspaper readers and journalists who remember that time remember it fondly.

THIS CHAPTER looks at the recent crisis in newspapers from a perspective that is gloomy and hopeful. As the business has been bludgeoned by falling circulation and advertising lineage, newspapers have shrunk in page size and number, sections have been cut, bureaus closed, beats shut down and journalists laid off in droves. Only an insane person would think of this as being good for the craft of journalism - though many newspaper publishers have attempted to sell the cutbacks to readers as improvements in the product. All the cutting and firing "have made a difference, eroding the quality, the essentiality, and certainly the uniqueness of what [newspapers] have to offer" (Tofel, 2012: 109). As we have seen, however, at the same time, technology has allowed journalists to employ exciting new research and story-telling tools, to take agency over their work and careers, to launch alternative publications, even to use new forms of communication as branding exercises that increase their worth in the information economy. As Deuze says, the news workplace is offering a stable, salaried work week for fewer people. More are finding 
themselves in the "portfolio workshop of the self-employed 'cultural entrepreneur" " who is "living in a state of constant change, while at the same time seemingly enjoying a sense of control over one's career" (2007: 23). That's an ideal state and may be the case for some, who move from job to job, project to project and team to team. For many others, however, it has meant unemployment or under-employment and a scramble just to make a subsistence living.

In North America, there has been a hollowing out of the mid-market, especially in the United States. However, that has been somewhat balanced by a rise in national dailies-such as the Guardian, Telegraph, Wall Street Journal, New York Times and, in Canada, Globe and Mail. There also is some hopefulness in the new interest in hyper-local journalism and the resiliency of the small-market dailies and community papers-but less so in Canada, where Quebecor's cutbacks have gutted dozens of small-market dailies, which it acquired through the Bowes and Osprey chains.

So, if the story of the business is one of crisis and the story of technology is one of hope, the story of the craft of journalism blends the two, into one of a very painful rebirth made necessary by business and aided by technology. Some of the more zealous advocates of public journalism - the hard-core Deweyans - see the future as one in which the conversation of the culture has been turned from a recital to a revival meeting, with the entire congregation on its feet: drilling down, bearing witness, photographing, tweeting, blogging, and shouting their opinions. Journalists, if they have a role, simply mediate the comments, so each can be heard. Others, the descendants of Lippmann, are horrified by the idea of the ignorant many replacing the 
educated few, and fear a future in which the facts cannot be heard above the din of bias and emotion. If Raymond Williams were around, he would doubtless continue to warn that the two extremes would open the door for opportunists-and, if the Web's extremist bloggers, political and corporate shills, and amoral propagandists are any indication, we should take heed. So, it is probably unlikely, and certainly undesirable, for either side to prevail entirely. However, we could, as Alan Rusbridger argues, keep both, and produce a new kind of journalism, in which "uniquely knowledgeable and insightful" professionalism is married to the "experience, range, opinions, expertise and passions of the people who read us" (2010).

CONRAD BLACK is a convicted white-collar criminal, and a businessman and press lord who once owned a chain of newspapers that more or less dominated English Canada. So, when he is asked about the state of the news media, one might expect him to deliver the party line about the recession, the Internet and the "broken business model." But Black is also a rogue, a pot-stirrer, a writer, a journalist and that very rare breed of newspaper proprietor, who cares deeply about the product-to the point that he once founded a daily as much for the fun of it as for the potential profit (see above). He is also a newspaper reader, and he doesn't mince words. Like a lot of readers, he is brutally blunt in his assessment of the state of the news business: "It's slowly collapsing under the weight of its own substandards." As for the blame: "The buck stops with the proprietor" (Kirby, 2010). Or, as movie mogul Samuel Goldwyn is reputed to have said: "A fish rots from the head." 
As we saw towards the end of Chapter 4, critics of newspaper management who were harsh in the 1990 s and 2000 s have become brutal in recent years, with much justification. News proprietors and executives have consistently cut the quality and standards of their product, and slashed their work forces while often rewarding themselves with handsome bonuses. For example, the Gannett chain, long associated with low-cost, low-quality journalism, big profits and shareholder satisfaction, has been identified as a premier example of "bonus excess despite miserable operations" (Carr, 2011). In 2011, a week before its flagship newspaper USA Today published an editorial attacking Wall Street bonuses, the company paid outgoing CEO Craig A. Dubow " $\$ 37.1$ million in retirement, health and disability benefits ... on top of a combined $\$ 16$ million in salary and bonuses in the last two years" (ibid.). As New York Times media critic David Carr reports, this was a newspaper chain that saw its stock tumble from $\$ 75$ to $\$ 10$ a share and its staff cut by 10,000 , a company that "strip-mined its newspapers in search of earnings, leaving many communities with far less original, serious reporting" (ibid.).

An even more appalling example of mismanagement is that of the Tribune Company under real estate mogul Sam Zell. Following the populist wisdom that the best way to deal with underperformance is to replace people who know what they're doing with people who don't, Zell brought in a whole layer of top management drawn from his radio holdings, led by former shock jock and Clear Channel executive Randy Michaels. Michaels's plan for revitalizing Tribune included identifying "change leaders and resisters ... promot[ing] and eliminat[ing] as appropriate" and "identifying people in the company he could 'get to drink the Kool-Aid.' " (O'Shea, 
2011: 289-290). Longtime Tribune news executive and onetime editor-in-chief of the Los Angeles Times, James O'Shea describes Michaels as someone who had a reputation for being a brilliant radio man, as well as a "boor" and serial sexual harasser, and whose plan for the newspapers was to emulate Matt Drudge and Fox news. One new section he proposed would have held "news up to a funhouse mirror: 'Knuckleheads in the News' " (ibid: 323-324). In a lengthy investigative feature for the New York Times (2010), Carr describes the "sexual innuendo, poisonous workplace banter and profane invective" of the company under Michaels and his associates. "They threw out what Tribune had stood for, quality journalism and a real brand integrity, and in just a year pushed it down into mud and bankruptcy," media analyst Ken Doctor said of the Zell regime (ibid.). Michaels was in charge from January 2008, a year before the company went into Chapter 11 bankruptcy protection (ibid.), to Oct. 2010 (Adams \& Lublin, 2010). Between May 2009 and February $2010, \$ 57.3$ million in bonuses were paid to Tribune managers, "with the approval of the judge overseeing the bankruptcy" (Carr, 2010).

In Canada, the situation is nowhere near as profligate, though that doesn't mean Canadian business executives aren't profiting while journalism suffers. When Canwest filed for bankruptcy protection, bonuses of $\$ 9.8$ million were approved for its executives (Gatehouse, 2009). Meanwhile, at Quebecor, the record has been one of cutbacks and consolidation, which is particularly confusing when you figure that the company owns 28 small-market daily newspapers and 165 community newspapers (Newspapers Canada, 2012)-exactly the products that have been shown to thrive in the era of Internet competition and hyper-local news coverage. Yet, the 
conversational thread among employees of the small papers at the Toronto Sun

Family blog (torontosunfamily.blogspot.ca) has focused almost exclusively on layoffs, cutbacks, closing of offices, and centralization of editorial production and advertising sales. The impression one gets reading these posts is that Quebecor has completely given up the primary market advantage of these papers: their closeness to their communities. A sample of the anonymous employee comments:

There was a time when industry "leaders" listened to the voice in the wilderness, because it was their job to do so. Now, industry "leaders" are only interested in bonuses and pay packages. ... I have sat at board meetings where senior executives have been more interested in the quality of the food that was served than the business being discussed. I have seen exceptional employees tucked into quiet corners and incompetent ass-kissers promoted. I have seen the exodus of talent and witnessed quality newspapers turned into glorified flyer carriers.... I'm not sure I can remain in an industry that is being systematically cannibalized by delusional management (RMP, 2010).

One wonders if Quebecor is not in the process of harvesting these operations to finance future growth in other areas. It's a procedure of which some U.S. companies have been accused, and the bonuses some are paying out certainly lends credence to the claim. Alex $\mathrm{S}$. Jones writes that harvesting is ...

... a business euphemism for stripping the carcass of every bit of flesh and then abandoning the pile of bones. It is a strategy designed for businesses for which there is no prospect of salvation, and it is nasty. ... For newspapers, harvesting would work this way. In the first five years, the industry-standard 20 percent profit margin might be greatly increased through cutting news staff-especially the most experienced people, who would likely be the highest paid. You would shrink the space for news, get rid of health insurance and other perks, and narrow the size to save on paper. You could save money by forbidding travel to cover news, require the remaining reporters to do multiple stories to make up for those who were laid off, cram the paper with syndicated material and wire services, avoid coverage that might anger advertisers or readers, and squeeze every dime you can out of the operating budget. The newspaper would still be produced. Its news columns 
would still be filled with words on paper that would look like news. But the enterprise that had been a living thing would essentially be a zombie (2009: 162).

He goes on to describe a spiral in which readers and advertisers turn away, but the momentum of the newspaper carries it for a few years, while the company milks the final profits out of it before finally discarding the husk: one long, going-out-ofbusiness sale and party.

All of this, Richard Tofel writes, is the product of an industry that was able to attract the best and brightest to the ranks of its craft, but not to the business side. "The best young reporters and editors aspired to go to work at precisely the companies where the young executives with the highest potential did not" (2012: 62-62). As a result, as we saw in Chapter 3, as early as the 1970s, the craft side had begun to feel strangled by a business side that lacked vision, daring and even "basic selfconfidence, [and] tended to employ rafts of consultants, often placed minimal emphasis on innovation and frequently knew little about technologies in their embryonic stages" (ibid.: 65-66). If there is a measure of how far down the business has dragged the craft, it may be in a letter former USA Today publisher and onetime Gannett chairman of the board Allen Neuharth sent to current USA Today publisher David L. Hunke in 2010. Neuharth, the architect of Gannett's method of driving up profit margins to satisfy shareholder expectations, was outraged that the paper had given over its front page to a wrap-around advertisement for Jeep. In the letter, he described it as "the low point in any decision any USA Today publisher has ever made." If it had happened during his tenure as publisher, Neuharth wrote, he would have led the staff in a walkout "that would leave those who apparently don't 
understand what a newspaper is to try to put one out without a news staff' (Peters, 2010b).

THERE IS something at the same time depressing and reassuring about the criticisms being levelled at the craft of journalism. It's depressing in that we're hearing the same complaints we've been hearing since the likes of Bagdikian, Underhill and Miller in the late 1990s: uninspired caretaker management; timid editorial leadership; too little concern for, or identification with, the interests and needs of the reader; a fascination with the lives of the rich and powerful, and too close identification with the same; a predictable agenda that puts readers to sleep with its sameness and blandness; overreliance on pundits to "explain" the world for us; objectivity misinterpreted as false 'balance' that sees only two sides to a story; too little focus on issues and too much on process. It's reassuring because the fact that people are still talking about these things indicates there is hope.

As we saw in Chapter 3, journalists often fare poorly in surveys of the public opinion of professions. To a certain extent this can be written off to a 'shoot the messenger' syndrome, and people within the craft have long assumed that making people angry is one sign that journalists are doing their jobs. However, through the recession, public opinion of journalism has continued to slide - not a positive sign for a field trying to convince people of its value to society. In Canada, however, the most recent poll shows public trust in the mainstream media improving, despite the gutting of many newsrooms and the multiplicity of online news sources. The following is by no means a complete or scientific survey of public opinion over the past three years, 
but I do believe it provides an accurate snapshot of North Americans' feelings about their news media.

In May 2008, the Canadian Media Research Consortium released a report on Canadians' opinion of their media that updated a similar study conducted in 2003. The "two main problem areas" identified were "declining interest and increasing cynicism." Of those surveyed, roughly a third aged 19-34 and around half the respondents of all ages expressed an interest in the news. When it came to trust, however, the response across all ages was roughly the same: a little more than half believed news organizations got their facts straight, between a quarter (19-34) and a third (all ages) said news organizations were willing to admit their mistakes, and a bit more than half believed news organizations were careful to check their facts. Finally, "nearly two-thirds of Canadians said they believed the news media cover up their mistakes" (CMRC, 2008). A survey done the following year by Ipsos Reid showed Canadians' trust in institutions was flagging in general, but journalists had actually gained a percentage point over 2003 , with 32 percent of the respondents saying they trusted people in the news business (Minsky, 2010). Similarly, the periodic Reader's Digest poll of "The Professions We Trust Most" for 2011 placed journalists near the bottom, in 30th place out of 41 , just behind financial advisors, domestic cleaners and lawyers, and just ahead of taxi drivers, mechanics and home building contractors (Reader's Digest, 2011). But, then, something very odd turns up. A survey by Angus Reid, released a month after the Digest poll, in May 2011, comes with the headline, "Even in the Digital Era, Canadians Have Confidence in Mainstream Media" (CMRC, 2011). In this poll, 90 percent of respondents of all ages and 88 percent aged 
19-34 rated the information in newspapers as "very reliable" or "reliable." For television news, the rating was 90 percent and 86 percent respectively and, for online news, 89 percent and 86 percent. The lowest rating went to social networks and blogs, with 26 percent and 33 percent (ibid.). Two key findings of the study were: "Professional editing inspires more confidence than 'crowd editing' on wikis and similar sites; most Canadians believe professional journalism is better at performing critical democratic functions than citizen journalism" (ibid.). Apparently we may not like journalists very much, but we have come to trust them.

In the United States, public opinion has followed a consistent downward trajectory. In March 2009, the New Republic published an article titled "MSM, RIP," that revealed 36 percent of Americans believed that the press "hurts democracy." Predictably the harshest critics were found on either end of the political spectrum, with left and right slamming "the same villain: the hypocritical biased elite media" (New Republic, 2009). Some of the criticism, the magazine reported, was creating a "poisonous atmosphere" that destroys the press's "authority in the culture." An example of typical rhetoric was this screed from the Huffington Post: "Beltway media really makes no effort to do anything other than parrot totally out-of-touch conventional wisdom - no matter how inane, stupid and ridiculous it is" (ibid.). The same month, the Pew Research Center released a report that showed only 43 percent of Americans believed that losing their newspaper would hurt local civic life, and only 33 percent said they would miss the daily paper if it were gone (Pew, 2011). This was followed in September of 2009 with an Associated Press story that ran in the Chicago Tribune under the headline "Survey Finds America's Crumbling Trust in 
the News Media's Accuracy Hits a 24-Year Low" (Liedtke, 2009). This poll, also from Pew, revealed that almost 63 percent of Americans "think the news stories they read, hear and watch are frequently inaccurate." That was up 10 percent over the results of a similar 2007 survey (ibid.). A year later, Gallup's annual Confidence in Institutions poll revealed that Americans were continuing to "express near-record-low confidence in newspapers and television news." This study claimed that "no more than 25 percent" of respondents said they had "a great deal" or "quite a lot" of confidence in print and broadcast journalism. The poll also revealed that Americans trusted newspapers about as much as they did banks and slightly more than Health Management Organizations (HMOs) and big business (Morales, 2010). In 2011, there was a slight rebound in the U.S. press's public image, followed by another punch in the gut. In June, Gallup's Confidence in Institutions poll showed the press up slightly: 28 percent of respondents said they had a "great deal" or "quite a lot" of confidence in newspapers, up from 25 percent in 2010; and TV news jumped from 22 percent to 27 percent (Meares, 2011). Sometimes, it seemed as if pollsters were working overtime to find new words the public could use to express disdain for the news media. In September 2011, the Pew Center released a poll in which 42 percent of the respondents described American journalism as "immoral," compared to 38 percent who considered the business "moral." The public was evenly split-42 percent each-over whether the press helped or hurt democracy, and two-thirds believed news stories were often inaccurate, compared to roughly a third in 1985 . Finally, only 25 percent of respondents said they thought news media get their facts straight, and 72 percent said journalists try to cover up their mistakes (Mak, 2011). A year later, 
Gallup released poll results under the headline "U.S. Distrust in Media Hits New High," and reported that 60 percent of respondents said "they have little or no trust in the mass media to report the news fully, accurately, and fairly" (Gallup, 2012).

In view of all this, it's not surprising that a 2010 Pew Center survey found a fairly strong sense of doom among U.S. editors in both print and broadcast news. Of the 353 respondents from the American Society of News Editors and the Radio Television Digital News Association: 48 percent said their organizations could not remain in business for more than 10 years, unless new revenue streams were found; 58 percent said journalism standards were slipping; 62 percent blamed the Internet (Pérez-Peña, 2010b). After all this, it's probably small comfort that yet another survey showed Americans overwhelmingly supported the idea of a watchdog press and the practices it uses to investigate public affairs: $\mathbf{7 5}$ percent said journalists should not have to reveal sources (Shahid, 2011). It appears Americans like the idea of journalism, but are not very happy with the practice.

Beyond that, it's pretty well anyone's guess what these figures meanespecially the ones in Canada, where everyone seems to have suddenly fallen in love with the news media after years of ranking them with used-car salesmen and financial advisers. There is probably little question that the polarized state of U.S. politics has something to do with Americans' dim view of their news media and, as the New Republic argues, it is very likely that the constant attacks on the "lamestream media" have poisoned the waters. As for whether trivialization of the news has lessened Americans' respect for their press, even that is highly doubtful. As the Columbia Journalism Review points out, the 2011 survey, which showed confidence in the press 
up slightly, was conducted during the full frenzy of "Weinergate"-the scandal about Rep. Anthony Weiner tweeting pictures of himself wearing only jockey shorts. At the peak of the scandal "when many of us had our heads buried in our hands sobbing about the state of the media, those interviewed expressed an increased level of confidence in this institution" (Meares, 2011).

IF THE public's opinion of the craft was in the dumps, so was that of many people in the profession. In the United States, where soul-searching and breast-beating are almost considered journalism skills, the craft was being reshaped and refashionedsome might say torn down-as it was being deconstructed and analysed. Even in Canada, where the culture of self-criticism is weak even at the worst of times, prominent journalists began to complain about a craft that seemed to have lost its drive. A lot of the criticism had a familiar ring.

Anyone labouring under the idea that political journalism had evolved since the 1990 s - that the insider baseball and horse-race coverage had given way to issuesdriven journalism - got a bucket of cold water in the face from Andrew Coyne in 2008. At the time writing for Maclean's magazine, Coyne fired a devastating barrage of criticism at the Canadian federal election coverage. Members of the Canadian parliamentary press corps, he wrote, were in "mortal peril of disappearing up our own backsides" (2008). Accusing the Ottawa press corps of "hurting democracy," Coyne described the coverage as being more of everything critics had been complaining about for years: mindless recycling of the parties' daily press briefings; chasing the polls; the "gotcha question" and "silly photo op"; the search for "defining moments" 
and "turning points" (ibid.). The question that never gets answered, he wrote, was the only one about which voters care: "Who are these people and what are they going to do to us?" (ibid.) If anyone in the press was listening, it wasn't reflected in the coverage of the 2011 federal election, about which Globe and Mail columnist Lawrence Martin was almost as scathing. The members of the Ottawa press corps, he wrote, had become old and passive, and got "co-opted" by the establishment they were supposed to cover. "Much wonderment has been expressed recently on why stories of abuse of power don't seem to hurt Stephen Harper's government. The stories don't stick ... because we in the media don't stick to them. It's episodic journalism" (Martin, 2011).

In the United States, the criticism was more extensive, sometimes to the point that it was hard to keep track of the complaints, but the ills identified were mostly the familiar ones: a tendency to blow up small stories and overlook big ones; short attention span; too little focus on the readers' interests; an alliance with the rich and powerful; a deep desire not to offend anyone.

Yet, most of the discourse remained focused on the "broken business model," and it seemed at times as if we had forgotten that the journalism model had been broken at least since the 1990 s. To a certain extent, this was owing to a widespread conviction that better journalism would never make for a return to profitability, so there was little point discussing it. As we saw in the first part of this chapter, there was a prevailing belief that many, if not most, proprietors and publishers "are not serious about the future of journalism; they are serious about cashing in as many chips as possible before closing time" (McChesney \& Nichols, 2010: 14). And the 
craft of journalism is unlikely to flourish in organizations that are in the process of harvesting, or believe that the future lies in a drastically reduced form of online journalism - “the creation of 'content,' meaning whatever will draw eyeballs" (Jones, 2009: 171). However, that only tells part of the story. To perhaps a greater extent, the craft of journalism has developed very bad habits - some based in business dictates and some not - that are making it difficult to adapt to the new realities.

For one thing, there is a timidity in news organizations about alienating readers, offending authority and threatening the status quo. Culture critic Bill Wyman argues that very few newspapers live up to their role as democracy's watchdogs because they crave advertisers, and to get the advertisers, they need circulation. "The real tyrant the papers served was the delicate sensibilities of their readers" (2009). The result is a product determined to be as uncontroversial and inoffensive as possible. This, as we saw in Chapter 3 , leads to a proliferation of bland service sections designed to create a comfortable home for advertising: gardening, travel, automotive and homes sections. Parts of the paper that traditionally blended hard news and criticism, such as entertainment and business, become boosterish and soft. Even in the news sections, it has been argued, North American newspapers became "far too polite to be subversive," unlike their "fierce, more anarchic, less obedient" British cousins (Lewis, 2007). Former British prime minister Tony Blair once described the British press as "feral" (ibid.). North American news media, on the other hand, have become "mindless amplifiers of government claims" (McChesney \& Nichols, 2010: 43).

McChesney \& Nichols go so far as to say that "the practice of journalism was 
anathema to most publishers," because "a healthy professional journalism is incompatible with corporate culture" (2010: 44-45). And, when it comes to stating the case for a more "feral" journalism, there is very little business argument to make. Newspapers that had won the circulation wars in their cities had a captive audience and it was that audience that had value, in terms of advertising revenue. Because the reader had never been made to bear more than a token part of the cost of collecting and publishing news, the content was worthless. Unfortunately, "newspapers that sought to retain readers by investing in their newsrooms have not been able to show that this strategy pays off with a surge in circulation" (Jones, 2009: 25). So, as we saw in Chapter 3, the strategy was to build and retain circulation with the advertising sections, special features such as comics pages, crossword puzzles, contests and chess and bird-watching columns, and a type of news that could titillate without offending or challenging authority. "[S]tories about sex scandals and celebrities have become more legitimate, because they make commercial sense: they are inexpensive to cover, attract audiences and give the illusion of controversy without ever threatening anyone in power" (McChesney \& Nichols, 2010: 47).

Also, as we saw in Chapter 3, as newspapers had moved away from serving a blue-collar audience and towards an upper-middle class one, they had moved closer to authority. In moving closer to authority, North American newspapers came to identify with the powers that be. That has led to some regrettable lapses, the largest and most disastrous of which are the U.S. press's inability to question the invasion of Iraq, and its blindness to the sub-prime mortgage bubble. "The main reason mainstream media is under siege is because on major story after major story, they got 
it wrong," Jeff Cohen of Fairness \& Accuracy told the Christian Science Monitor.

"It's because of the botched reporting in the run-up to the Iraq invasion and the totally missed financial crisis. The independent new voices have blossomed because of their content failures" (Goodale, 2010). Similarly, in Canada, Prime Minister Stephen Harper prorogued government for three months in 2008-09 to avoid a confidence vote and the near-certainty of being toppled by an NDP-Liberal-Bloc Québécois coalition. The Canadian press did very little to challenge the Conservative Party line that a coalition was illegitimate and anti-democratic-despite a wealth of national and international precedents that prove otherwise. "When the Governor-General made her decision to sustain the Conservative government in office, she gave no explanation. Instead of demanding one, our media folded like deck chairs” (Martin, 2009).

North American journalism has created a culture of caution and subservience that has made it predictable, bland and conformist-and that makes it ill-equipped to compete with the unpredictable, daring and diverse Web.

Today, mainstream print and electronic media want to be neutral, presenting both or all sides as if they were refereeing a game in which only the players - the government or its opponents - can participate. They have increasingly become common carriers, transmitters of other people's ideas and thoughts, irrespective of import, relevance and at times even accuracy.... At a time when it is most needed, the media, and particularly newspapers, have lost their voice (Pincus, 2009).

When the press is perceived to have fallen down on the job, people look for alternatives - as they did in the 1960s and early '70s with the underground press and the New Journalism. The various bloggers, pundits, independent journalists and aggregators on the Internet have provided the equivalent of a fairly powerful alternative press. Sites such as Talking Points Memo, Truthdig, Voice of San Diego, 
Minnpost, Politico and Global Post in the United States have all stepped in to provide alternatives where there was perceived to be a vacuum. In Canada, there are the six OpenFile sites, the left-wing aggregator Rabble.ca, and a few local alternative sites, such as Torontoist and the excellent Tyee. The last may be Canada's most consistently interesting news site, a blend of original reporting, columns and opinion that was founded by journalist David Beers as an antidote to the blandness and boosterism of Vancouver's Pacific Press monopoly, owned by Postmedia. However, as Compton and Benedetti argue, the existence of an alternative media is cold comfort unless there is a fully functional mainstream media for it to influence:

A model of journalism that is reliant on the serendipity of wellmeaning, cell phone equipped citizens is no substitute for the day-today grind of reporting and fact checking required to cover state institutions, such as the court system, or the financialization of the securities industry that contributed to meltdowns in the North American and UK housing markets. The fact that traditional news organizations failed to provide sufficient coverage of financial ponzi schemes or for that matter government war propaganda in the run up to the invasion of Iraq does not provide much comfort unless it can be demonstrated that citizen journalism can replace this unfulfilled labour (2010: 493).

It says something very bad about U.S. journalism that one of the most powerful and intelligent alternative voices belongs to a comedian. In 2009 , Jon Stewart, of The Daily Show, was voted "America's most trusted newsman" in an online poll conducted by Time magazine, beating out ABC's Charlie Gibson, NBC's Brian Williams and CBS's Katie Couric (Linkins, 2009). Psychology Today compared Stewart to Ralph Nader, as an advocate for the people, and explained that 
Stewart's appeal lies in the fact that he tries to give his viewers the "REAL' story behind the media spin and perceived (and actual) media bias" (Riggio, 2009). As well, Stewart and his fake-pundit partner-in-crime Stephen Colbert fill a vacuum left by the absent counterculture voices from the left, the "traditional sources of opposition to corporate rule," which have become old and tired and have ceded the media to neo-conservatism (Martin, 2009). Though Stewart has always been adamant that he is an entertainer and not a journalist, his power-and by extension the unexploited power of the press-is evident in the pressure he put on the U.S. Congress to pass a bill pledging health-care funds for $9 / 11$ first responders. In a Daily Show episode that featured several New York fire, police and emergency personnel, Stewart singled out two groups for attack: Republicans who filibustered the bill, and the news media that had ignored the issue. Stewart sarcastically pointed out that the TV networks had been forced to choose between covering the Beatles arrival on iTunes or the first-responders. Shortly after the show, the bill passed. Syracuse University television professor Robert Thompson rated Stewart's performance as one of the three great moments of advocacy journalism on TV: along with Edward R. Murrow's exposing of Senator Joseph McCarthy in the 1950s and Walter Cronkite's editorial about the Vietnam stalemate in 1968 (Carter \& Stelter, 2010). The disturbing thing is that a satirist had to take the lead in the story, and no one in network news followed. Basically, it was TV's answer to the editorial-page cartoonist who was left to show the power of the press.

At the same time, the mainstream media have allowed the new media, and

\footnotetext{
${ }^{1}$ His emphasis.
} 
some of their most extreme elements, to dictate the agenda. As Paul Starr has pointed out (2010) U.S. politicians today are facing the most partisan media since the 19th century. As the political culture has become more polarized, the pundit culture has become more extreme. Talk radio and news network commentators have amped up the rhetoric to levels of incivility that once would have got them banned from the airwaves. Washington Post columnist Howard Kurtz calls it "journalism as blood sport, performed for the masses.... The toxic atmosphere that many media outlets tolerate, and sometimes foster, is slowly poisoning the discourse" (2010a). The danger in this - when "the world of Walter Cronkite gives way to the world of Glenn Beck and Keith Olbermannn"-is that society loses a vital political tool, a trusted, impartial press that is "a resource for building consensus" (Starr, 2010).

Further driving the public agenda is the speed with which the news moves, combined with the fact that, as Lawrence Martin pointed out, the media have developed such a short attention span. For example, there's the case of U.S. Department of Agriculture employee Shirley Sherrod, who was more or less crucified in the mainstream press after an out-of-context video was run by online neoconservative propagandist Andrew Breitbart. The video had been maliciously edited to present Sherrod as an anti-white racist and, when the TV networks got hold of it, they ran it without further investigation. Sherrod was fired. Then she was vindicated when someone bothered to look at the whole clip, and realized that the socalled racist comments had been created by removing context. "The herd ... moves so quickly that snap judgments prevail and nuance gets lost" (Kurtz, 2010b).

It is most often, but not exclusively, the conservative new media that is 
driving the agenda, operating with a game plan that dictates that anything is fair, as long as it advances the cause. So, we live in an age of truth and, to use Stephen Colbert's brilliant term, "truthiness," a belief that something need only have the ring of reality to it to be useable in the public sphere. For example, around the time of the invasion of Iraq, a "presidential aide" was quoted in the New York Times Magazine as sneering at the "reality based community" of journalism and saying of the George W. Bush administration: "We're an empire now, and when we act, we create our own reality. ... We're history's actors and you ... all of you, will be left to just study what we do" (Cited in Rich, 2006: 3).

Driven by the need to appear objective, the mainstream media plays into the hands of those who seek to create their own reality, and gain by manipulating the message.

In many quarters of the Old Media, there is concern about not appearing liberally biased, so stories emanating from the right are given more weight and less scrutiny. Additionally, the conservative New Media, particularly Fox News Channel and talk radio, are commercially successful, so the implicit logic followed by decision makers in the Old Media is that, if something is gaining currency in those precincts, it is a phenomenon that must be given attention. Most dangerously, conservative New Media will often produce content that is so provocative and incendiary that the Old Media finds $[s i c]$ it irresistible (Halperin, 2010).

This is a further indictment of the cult of objectivity. As in the 1950s, when the news media allowed Communist witch-hunter Joseph McCarthy to run amok by objectively reporting everything he said without investigating or questioning it, today the news media allow propagandists such as Breitbart and James O'Keefe (see Chapter 5), to place their agendas in front of the people unchallenged. The stupidity of objectivity as it is practised has been repeatedly attacked. Often it takes the form of 
a mindless striving for balance, a "phony objectivity in which the reporter quotes advocates of both sides ${ }^{2}$ of a controversy without any independent probing to discover the facts" (Jones, 2009: 84). This can mean that the findings of research scientists can be cast in doubt by industry shills, put forward to simply muddy the stream of discourse and make consensus impossible. "If Joe says the sky is blue and Jack, who is widely known to be a delusional psychotic who has just taken two tabs of acid, says it's purple with pink polka-dots, is it really necessary to report what Jack says?" (Kamiya, 2009). Objectivity can be an excuse for abdicating the prime responsibility of the journalist (or of any artist or communications craftsperson, for that matter): to discern the truth. Simply parroting the controversy and leaving it for the audience to decide is an act of professional irresponsibility, and journalism, to a certain extent, has interpreted it as a virtue. As Starr says, "Democracy needs a passion and partisanship provides it. Journalism needs passion, too, though the passion should be for the truth" (2010). Indian investigative journalist Palagummi Sainath proudly admits to being an advocacy journalist, and one of his specialties is advocating for the poor, often at the expense of government credibility. He is famous for dismissing as stenography journalism that fails to question authority. As he told documentary filmmaker Joe Moulins:

I believe what we call value-free or neutral journalism is essentially the journalism of the advertiser and the monopoly house. The journalism of status quo always provides as being neutral, because it wants neutrality. Because it defends and protects, and influences the status quo. The status quo may be a very good thing, but I don't believe in India that it is. It's a very reactionary and very bad thingas I believe it is in most societies in the world (2002).

\footnotetext{
${ }^{2}$ As opposed to all perspectives.
} 
THAT BRINGS us to another recurring theme: that journalists need to redefine what they do so they can adapt to an audience that has lost patience with the "journalism of the advertiser and the monopoly house." As always, very close to the centre of the discussion is the question of objectivity, whether it needs to be redefined or abandoned altogether.

Typically, the argument to abandon it centres on the need to draw the audience away from the breeziness of the aggregators, and the fiery, opinionated writing of the blogosphere. Often, this is interpreted as meaning journalists need to do both: be informative and breezy while liberally spicing their reporting with opinion. This is a blend Stephens (2007) calls "wisdom reporting." With the Internet delivering more facts than we could ever need, he argues, newspapers need to offer readers a more thoughtful experience. Reporters need to do more than just gather facts; they have to analyse and interpret the news.

[O]utside of the small patch of the paper that has been roped off for opinion, the chances of coming upon something that might qualify as wisdom are not great. Most reporters have spent too long pursuing and writing "just the facts" to move easily into drawing conclusions based on facts. Their editors have spent too long resisting the encroachment of anything that is not carefully sourced, that might be perceived as less than objective, to easily welcome such analyses now (ibid.).

It's hard to see how that would be a formula for drawing people away from the "wisdom" that grows like Kudzu all over the Internet. Also, the main question Stephens raises is, Why is opinion the opposite of objectivity? It could as easily be argued that the opposites of objectivity are skepticism and curiosity. If someone makes a comment, don't just print it. Investigate it and, if it is false, report that. When Jon Stewart did his show about the first-responders, he used news video, and testimony from the first responders to 
present an argument built on a very strong set of facts: the mainstream press was ignoring the issue; Republicans were cynically stalling the bill; first responders were getting sick and dying. It was for the audience to conclude that there's something rotten about a system that waits for heroes to die so they don't have to pay for the injuries they sustained being heroes. As Arianna Huffington says, "Very often, truth is on one side or the other. That's not partisanship" (McChesney \& Nichols, 2010: 95). The reason people are turning away from newspapers is that the audience understands this, and is not "buying their pious pronouncements about maintaining objectivity" (ibid.). He said/she said reporting is not "authentic" objectivity; it is the "discredited face of objectivity" (Jones, 2009: 83).

As we have seen, critics such as Bagdikian (1990, 2004), Carey (1997d), Hallin (1989), McChesney (1999, 2010), Nerone (1995), Rosen (1999) and Schudson (1995) have pointed out that there is a set of shared values implicit in journalistic discourse that renders objectivity impossible. "For instance, the articles that appear in mainstream newspapers are written with the undeclared assumptions that capitalism isn't inherently evil and freedom of speech is a virtue" (Jones, 2009: 83). As Rosen says, part of the problem with objectivity is that journalists routinely place issues and information into the spheres of legitimate controversy, consensus or deviance, but rarely think very much about it and almost never question the process. "Which means they often do it badly. ${ }^{3}$ Their 'sphere placement' decisions can be arbitrary, automatic, inflected with fear, or excessively narrow-minded" (Rosen, 2009).

The liberal blogger Atrios, probably giving away his age, has a term he uses for thinkers who lie in the sphere of deviance: "dirty fucking hippies"

\footnotetext{
${ }^{3}$ His italics.
} 
(www.eschatonblog.com). It's the way he refers to himself and it harks back to the days when people like Richard Nixon and Spiro Agnew could dismiss antiwar protesters as dirty, longhaired bums who needed to get a job, and then see their words in headlines across the United States. The modern equivalent is "the out-of-power or online left and the way this group is marginalized by the Washington journalists ..." (Rosen, 2009).

Unfortunately, as we saw with the later years of the Vietnam War, occasionally "the people the press thinks of as deviant types are closer to the sphere of consensus than the journalists who are classifying those same people as 'fringe'" (ibid.).

As we saw in Chapter 2, there was a time when newspapers found it was in their interests to align themselves with the fringe, when magnates such as Hearst, Pulitzer and Atkinson saw profit and power in courting the burgeoning immigrant and working classes. Also, in the late 19 th and early 20 th centuries, many journalists had come from those classes and made small enough salaries that they remained there through their working lives. Today's journalist, more often than not, has little experience outside the uppermiddle class. Children of privilege, trained in the best universities and working in glass towers or suburban bunkers, they often aspire more to be confidantes of the rich and powerful than advocates for the helpless. CNN pundit David Gergen has decried the fact that most journalists are "upper income, living in this rarified world, and we are more and more removed from the problems of working-day people" (Houpt, 2012a). He says he urged one young woman on his staff to leave Washington and take a job on a small-town New England paper, so she could "really understand what's going on, and the lives of people who are making $\$ 30,000, \$ 40,000$ a year ... And we need people who can do that" 
(ibid.).

As we saw in Chapter 3, newspapers long ago shifted their attention away from their loyal blue-collar readership to become products aimed at the well heeled readers their advertisers desire. It seems hard to believe, but there was a time when almost every daily newspaper had a labour reporter. Now, there are almost none.

[E]very daily newspaper in North America came to include a business section-filled with news for the investor, the manager, the executive and the employer, and flush with advertising. But not one included a labour section that addressed the employee, was attentive to working conditions, and chronicled the experience of the unemployed. There was no commercial base, no advertising constituency ... (Dornan, 2012: 57).

To the press of today, "Iploor and working-class people are, for all intents and purposes, only newsworthy to the extent they get in the way of rich people" (McChesney \& Nichols, 2010: 51). As such, they are reported as criminals and victims, or the collateral damage of economic necessity. Normally, there is one day each year that the American media admit the existence of the poor, the Huffington Post wrote in 2009: the day the U.S. Census Bureau releases its annual report on poverty (Linkins, 2010).

Similarly, critics of the press coverage of the Occupy Wall Street movement focused on the reporting and commentary as being disparaging and one-sided, or too narrowly focused on horse-race coverage, like an election. Alicia Shepard of National Public Radio complained that most of the coverage "hasn't been about the issues, it's been about who's up and who's down" (Stelter 2011). Fox News felt free to denounce the protesters as "nuts, lunatics and fascists" and "demonic loons," while MSNBC mythologized them as "what working people are talking about" (ibid.). In both cases, the discourse was safer than discussing the images they were broadcasting, some of which 
involved people who had plunged the world economy into anarchy jeering those whose lives they had destroyed. Columbia Journalism School professor Dale Maharidge explains this as just another manifestation of journalists' isolation from "real people." "Right now, there's too much emphasis on talking heads ... Too many reporters want to focus on the sound bytes. Some are just lazy. But most have this default position where they're going to repeat the official line" (Linkins, 2010). Perhaps the best argument for covering the working class and others who fall into the sphere of deviance is that they're simply more interesting than the contented suburbanites the newspapers are trying to reach with their stories about minivans, tofu recipes and retirement investments.

BUT, THEN, North American journalists long ago came to think of themselves as part of the professional class and this, in the view of their British counterparts, has made their work "self-reverential, long-winded, over-edited and stuffy.... The British sometimes argue that, because American journalists have joined the establishment they are easily duped by senior sources" (Rachman, 2008). British journalists, on the other hand, cherish their status as social outsiders and "like to quote the adage of the late Nicholas Tomalin that: 'The only qualities essential for real success in journalism are rat-like cunning, a plausible manner and a little literary ability" " (ibid.). This has a positive side and a sinister one. On the positive side, most British journalists find North American pomposity either insufferable or hilarious, and see North American journalists as being far too cautious for the good of their craft. On the sinister side, many British journalists particularly the 'Fleet Street reptiles' of the tabloid press-are possessed of a cynicism that their North American colleagues find unnerving. A prime example is the recent 
phone-hacking scandal that brought down News Corp.'s Sunday tabloid, News of The World, and landed its proprietor, Rupert Murdoch, in front of a public inquiry into press ethics. As of mid-2012, there had been 19 charges brought against eight senior News Corp. editors and journalists - including former News International CEO Rebekah Brooks and former communications director to Prime Minister David Cameron Andy Coulson; both are onetime News of the World editors (Evans, 2012). Among the most unsavoury charges is that News of the World reporters hacked into the cell phone of a murdered girl and deleted messages, so that the phone could accept more-giving her parents false hope that she was alive. In a symbolic gesture of good will, Murdoch shut down the News of the World-but replaced it with a Sunday edition of his equally rabid Sun tabloid.

On the other hand, the British press has a history of thumbing its nose at authority that is healthy and refreshing by our standards. For example, Ryan Perry, a reporter for the Daily Mirror, once landed a job as a footman in Buckingham Palace, and wrote a fascinating series of insider accounts of life among the Royals, which was totally unauthorized. As U.S. journalist James Geary put it, British tabloid journalism has a "certain gaudy brilliance" that harks back to the muckraking of the penny press (2006). At the same time, the quality papers, the Times, Guardian, Independent and Telegraph, showcase some of the most literate, stylish and intelligent writing in the world, which succeeds, as Tina Brown pointed out, in also being sexy, entertaining, thought-provoking and fun. And it is difficult for anyone exposed to the steady ooze of bile and pablum on the North American news networks not to be envious of Britons whose main TV diet consists of the BBC. In the run-up to the Iraq war, a common criticism among British journalists was that their American counterparts tended to be far too polite and deferential 
to authority, to the point that many Britons considered their U.S. colleagues "incredibly soft" and "patsy-like" (Hansen, 2007).

Unlike in the U.S., where journalists generally strive for at least the appearance of neutrality and balance, British papers have a long tradition of openly allying with political parties and flouting [sic] their partisan passions. Some veteran British media watchers ... say that this has a liberating effect, which, combined with the fact that Britain still has a dozen or so national dailies battling it out for readers, makes the British press (high-end papers and tabloids alike) edgier and more fun to read (ibid.).

As Jack Shafer says, it might be a welcome change if some of our newspapers took a cue from the British and "contained a little more blood" (2009). To a lot of commentators, the newspapers' verbosity and self-indulgence has contributed to the information glut and the noise without bringing much perspective to it. Somewhere along the line, newspaper reporters got the idea that the best way to kill the inverted pyramid was to develop a style that teased, and mystified the reader. One hallmark of this is the anecdotal lead, used even when unnecessary or inappropriate: "those you'll-never-guesswhat-this-is-about faux mystery narrative leads" (Bates, 2010). Evaluation is smuggled into a story in the guise of expert quotes that "magically turn an opinionated story into an objective one" (ibid.). And words are piled upon words in a style that makes "consumers feel bad about themselves" because they "just can't handle that much information" (Dumenco, 2009). Perhaps the best arguments for newspapers that don't publish daily are the pages and pages of punditry, repetition, speculation, argument and, mostly, recycling of predictable "generic" stories, which seem to be pulled from a data-base of tired allpurpose headlines that substitute for the more difficult "good stories begging to be told" (Shafer, 2010b). Copies of these newspapers "pile up, often largely unread.... time and 
time again you probably find yourself quitting pieces after the first few paragraphs, or somehow getting all the way through them and thinking, 'That wasn't worth my time'" (Dumenco, 2009). Shafer argues that one way to cure the condition would be to return to the values of the penny press. It's time, he argues, that newspapers "[t]ook a position without being partisan, yelled a tad more, and brushed some yellow from the palette while painting their stories" (2009c). With all its sensationalism, social conscience, combativeness and disrespect for authority, "yellow journalism possessed an effervescence, a visceral and essential appeal that newspapers 100 years later seem desperate to recapture" (ibid.).

SO, WITH the daily newspaper on its way to being a niche product for an affluent audience, and the Internet a collection of chambers in which people can confine themselves to talking only to the like-minded, we are "about to enter a fractured, chaotic world of news, characterized by superior conversation but a decidedly diminished level of first-rate journalism" (Alterman, 2008). That raises the question of who in this world of endless conversation is a journalist and what is journalism - and whether we should even need, or dare, to define those things.

To begin, perhaps we should deal with the proposition that journalists are "professionals," who can be accredited like lawyers and doctors-as has been suggested in some quarters, such as in Quebec by the Fédération professionnelle des journalists with their call for news people to be licensed (Neil, 2011). The argument against this kind of accreditation is that it is exclusive, elitist and protects lazy, insider journalism - that the "huffing and puffing about interloping amateurs all too often conceals the fact that these 
amateurs know as much or more about the subject as the professionals, and are not subject to being bamboozled by 'insiders' with an agenda" (Kamiya, 2009). Proponents of a stricter professionalism generally cite the propagandists who masquerade as journalists, bloggers who are unaware of or unconcerned with ethical and legal issues, and well meaning citizen journalists who get themselves into trouble. Take for example these comments from Andrew Cohen, a Carleton University journalism professor and columnist for the Ottawa Citizen: "And so it is with journalism today. Like politics and novels, it is open to anyone, which is why the unfiltred, unregulated, unedited Internet is full of trivia, scandal, prejudice and falsehood, and why a generation thinks the Daily Show (however clever) is the news and advertising flyers are newspapers" (2009). Cohen is decrying the coverage a rookie reporter named Amanda Lindhout received after she had spent 15 months in captivity in Somalia, where she had gone to file freelance stories for a small Alberta paper. He describes her as a "dilettante, a gutsy, friendly, chirpy naif" and seems to take particular offence to the fact that reporting for state-controlled Iranian TV news and the Red Deer Advocate were "the limit of her influence" (ibid.). Representing the opposing point of view - that journalism is a field whose only standard is performance-a National Post columnist wrote that it is disturbing to see "one journalist attack another for excessive initiative, independence and bravado ..." (Selley, 2009).

Meanwhile, a proposal similar to that of the Quebec journalists federation, put forward by Daily Mail editor Paul Dacre, has touched off a debate about professionalism in Great Britain. Dacre suggests that British journalists be accredited by and answerable to a professional body charged with upholding press principles (Ball, 2012). Perhaps it is understandable that there would be some support for the idea of stricter controls on an 
industry that, in light of the phone-hacking scandal, appears to be out of control. And some media outlets have supported Dacre in principle, including the daily Independent, which argues that one of the functions of the regulating body "might be the issuing of a press card which could be suspended or withdrawn from individuals who gravely breach those standards" (ibid.). Not surprisingly, the online world rose up to denounce the idea, and there were several expressions of concern that such a system would "kill off local voices holding power to account" (Geary, 2012). It is somewhat disturbing to think an occupation dedicated to free speech would ever consider adopting a licensing apparatus or any other form of professional accreditation that could be used to bar people with points of view that are unpopular with government or corporate interests-or with other journalists. One can easily see a parallel to Nerone's criticism of the Social Responsibility Theory of the press. Just as "strict, often draconian press control is always justified by dragging out the concept of 'social responsibility' " (1995: 134), it is easy to see how professionalism could be used as a club to beat bloggers, citizen journalists and other members of the alternative press.

Yet, Cohen, Dacre and the Quebec journalists' federation are just three examples of a rising chorus of voices urging some kind of professional definition of journalism. For example, there's the case of Oregon "investigative blogger" Crystal Cox, who was ordered to pay $\$ 2.5$ million in damages to a Portland financial company because, in one of her blog postings, she accused one of its officers of tax fraud (McCann, 2011). The electronic Frontier Foundation asked U.S. District Judge Marco A. Hernandez to overturn the jury award, "as a threat to free speech, excessive [sic], and based on the wrong standard of defamation law" (ibid). As it turns out, Cox's standards of journalism were very loose. 
Her reporting has been revealed to be a collection of unsubstantiated claims and personal attacks, and the plaintiffs had good reason to sue and Hernandez good reason to uphold the award. As David Carr wrote, in times past, she would have been someone who pestered city editors with her theories. "The Web has allowed Ms. Cox to cut out the middleman; various blogs give voice to her every theory, and search algorithms give her work prominence" (2011c).

What makes the case noteworthy is Hernandez's response to the issue of whether Cox, as a blogger, could expect the same legal protection as a "professional journalist" under U.S. law. On Page 9 of his 13-page ruling, Hernandez set out seven requirements for journalistic professionalism:

Defendant fails to bring forth any evidence suggestive of her status as a journalist. For example, there is no evidence of (1) any education in journalism; (2) any credentials or proof of any affiliation with any recognized news entity; (3) proof of adherence to journalistic standards such as editing, fact-checking, or disclosures of conflicts of interest; (4) keeping notes of conversations and interviews conducted; (5) mutual understanding or agreement of confidentiality between the defendant and his/her sources; (6) creation of an independent product rather than assembling writings and postings of others; or (7) contacting "the other side" to get both sides of a story. Without evidence of this nature, defendant is not "media" (Hernandez, 2011).

Carr calls this "a MacGuffin" (ibid.) as in Alfred Hitchcock's name for a meaningless device that moves the plot forward, and that may be true as far as the specifics of Cox's case are concerned. However, in terms of setting a precedent, there is some reasonable cause for concern in that it gives litigators a weapon they can use to discredit almost anyone who practises the craft of journalism-and one wonders why Hernandez even felt the need to write it into his opinion, since no legal shields protect journalists from the consequences of slander. As Forbes blogger David 
Coursey points out, most of the people working in city rooms couldn't produce the credentials necessary to meet Hernandez's criteria, but they have the protection of large media organizations. The issue of "who is and who isn't a journalist may come down to just one thing: money. Who has it (typically the person who says you aren't a journalist) and who doesn't (typically the freelance journalist, even if working for a big name publication)" (Coursey, 2012). Even with the support of a big news organization, investigative journalism can be a very expensive game, largely because civil law is the most powerful weapon people who are being investigated can use against those doing the investigating. As for the rest of us, not many have the resources "to play very long" (ibid.).

There are privileges that journalists enjoy that could be a bit more problematic, such as the right to protect sources and the argument of fair comment. Clay Shirky argues that, when anyone can become a journalist and journalists enjoy "certain latitude to avoid cooperating with the law ... journalistic privilege suddenly becomes a loophole too large to be borne by society" (2008: 71). The problem lies in limiting it so that the law maintains its "ability to uncover and prosecute wrongdoing while allowing a safety valve for investigative reporting" (ibid.). So, where does society draw the line? Options such as the ones suggested by the Quebec journalists federation or Paul Dacre could have the effect of shutting down the citizen reporters who have stepped in to fill voids left by a retreating professional journalism. For example, the collapse of the community press in Great Britain has left dozens of town councils with no journalists to watch over them. Volunteers who cover council meetings already "tell tales of obstructive council representatives and exclusion from 
meetings because they are not considered 'proper journalists' " (Geary, 2012). The institution of some kind of press card would make it much easier for public institutions and corporations to simply ostracize people like them.

As Shirky writes, the "definition of journalism is not internally consistent but is rather tied to ownership of communications machinery" (2008: 72). When it comes to offering a definition for journalist or journalism, however, he skirts the issue with predictions of a future in which everyone is a publisher. Coursey jokingly compares journalism to pornography, invoking U.S. Supreme Court Justice Potter Stewart's famous line: "I know it when I see it" (2012). But he may be on the mark. It took years for courts to deal with laws governing obscenity, profanity and pornography, case by case. Some of the most famous, such as the various prosecutions of comedian Lenny Bruce, the attempt to ban Allen Ginsberg's poem "Howl," and the 1960 trial of Penguin books for publishing Lady Chatterley's Lover, involved long days of expert testimony to establish the social and artistic values of the works in question. We could be in for a long series of debates like those as we struggle to define which bloggers and citizens are journalists and deserving of protection under the law. Once again, we may be called upon to court the abyss, and deal with questionable practices, one by one, as they come up, so we can protect the free speech that is valuable. "[D]efining the line between them is tricky and is best decided giving the benefit of the doubt to the journalist" (Coursey, 2012).

AS WE saw in Chapter 4, there have been more than 40,000 layoffs in the U.S. newspaper business alone since January 2007. That has made for a lot fewer 
journalists and a lot more bloggers, citizen reporters and public relations workers. And, when there are a lot fewer eyes on politics, culture, business and all the forces shaping our lives, and a lot more hands fashioning the message those agencies would like us to hear, "It the bad guys get away with stuff" (Reporter Tom Dubocq, quoted in Walton, 2010). The current situation in journalism is having the dual effect of making it more difficult to keep an eye on the bad guys and making it easier for bad guys to look like good guys.

This is not to say that everyone who works in public relations or employs someone in PR is a bad guy, just that it's probably not desirable for the people advancing an agenda to have all the tools. "The muscles of journalism are weakening and the muscles of public relations are bulking up-as if they are on steroids," New York Times reporter David Barstow recently told the Columbia Journalism Review (Sullivan, 2011). Journalists have always been outnumbered, but the imbalance has grown mightily. For example, in the United States, in the 1980s, there were about .45 PR workers and .36 journalists for every 100,000 population; by 2008 , that ratio had changed to .90 PR workers and .25 journalists, and between 1997 and 2007 , revenues at U.S. public relations agencies went from $\$ 3.5$ billion to $\$ 8.7$ billion - figures that only take private agencies into account, and not advertising agencies, corporate PR departments or lobbyists (ibid.).

As Shirky has pointed out, the Web is breaking things faster than new things can be built. And until those new things can be built, or the old ones adapted to the new situation, more and more of our public life "will occur in the shadows. We won't know what we won't know" (Tom Rosenstiel, quoted by Starr, 2009). But we will know what some people want us to know. 
Starr speculates that the omnibus, metropolitan daily that we all grew up with may be a construct that is peculiar to a specific set of conditions and, thus, to a certain moment in history. "We may be approaching not the end of newspapers, but the end of the age of newspapers" (2009). As a central form of communication in cities around the world, newspapers gave us "a powerful means of leverage over the state, and this leverage is now at risk" (ibid.). The central question, from a social and political point of view, is what will replace the newspapers, if anything. Starr warns of a "new era of corruption" (ibid.) brought about by corporate and government organizations and agencies that find themselves suddenly able to operate without supervision.

This is obvious cause for concern, although, as we have seen, many critics consider the point irrelevant, arguing that most North American dailies Iong ago abdicated their watchdog role in favor of soft news, entertainment, and consumer advice. Also, there are organizations popping up to fill the void. Groups such as California Watch, the Center for Public Integrity, Politico and the Pulitzer-prize winning ProPublica are responsible for "an emerging ecosystem of investigative reporting" (Drew, 2010). Relying on foundation funding and public donations, they publish on their own Web sites and offer their material, often free of charge, to newspapers and TV news organizations. Often, they do big, splashy investigations in partnership with other news outfits, as ProPublica did with "Law \& Disorder," an investigative series on the conduct of the New Orleans police department after Hurricane Katrina, which was done with the Times-Picayune newspaper and PBS's current events series Frontline (Saba, 2010). The new non-profits have to produce to survive; they "can only hope to get their next round of donor cash if they produce something tangible" (ibid.). That means they need to get attention, which, in turn, means 
they prefer to go after sexy stories. The emergence of these organizations has been met with less than universal acclaim by newspaper editors such as Los Angeles Times deputy managing editor Marc Duvoisin, who fears investigative reporting is becoming like opera, once universally popular with the masses and now an acquired taste for the select few (Drew, 2010). Toronto Star columnist Kelly Toughill, also chair of the journalism department at Halifax's University of King's College, worries that "news has become a charity case. ... lumped in with housing the homeless, preserving wetlands and advancing cancer research" (2008). The concern is that, while the high-profile journalism "charities" scoop up funds for the big, prestigious stories, the day-to-day investigations that protect and serve people and institutions on a local level will be left undone. There are local initiatives, such as San Francisco's Spot.Us, which solicits public donations by posting story ideas and asking readers to contribute, and its imitator, GoJournalism, which was set up by Ottawa's Algonquin College (Spot.us, GoJournalism.ca). But, again, it's likely the sexy stories will get funded, while the necessary, workaday, ones will be left to the dwindling supply of full-time journalists. As blogger and industry analyst Alan D. Mutter put it, nonprofits are "boutique operations that are picking certain stories and certain subject matter, and they're not going to replace feet-on-the-street beat reporting, peering into all the little nooks and crannies in the communities of this country the way the commercial, traditional press has done." Sometimes, the mainstream press "has done an awful job" and the nonprofits "are going to do some good, but they're not replacing that which has been lost" (Walton, 2010).

Perhaps of even greater concern is the old fear that the idealists and the realists may be leaving a very large opening for the opportunists and the manipulators to exploit. 
It seems fairly obvious that the combination of a diminished press and a hungry, underpaid or unpaid amateur press corps will be ripe for exploitation by the growing and ever more powerful public relations industry.

"What's sailing away into the 21 st century is the common conception that writing is a profession -or at least a skilled craft that should come not only with psychic rewards but with something resembling a living wage" (Rainey, 2010). As journalists have been thrown out of work, alternative means of employment have been getting more and more meagre. Magazines are paying lower rates, newspapers are using fewer stringers, and "content farms," such as Demand Media, have flourished paying writers as little as five cents for a short piece designed for search engine optimization, on topics such as "How to Wear a Sweater Vest" or "How to Massage a Dog that Is Emotionally Stressed" (Hiar, 2010). As we saw in Chapter 5, aggregators such as the Huffington Post are largely built on low-cost or free content, and social networks are built for free, by offering a service that collects an audience that is sold to advertisers - the same principle as the newspaper, but with the greatest expense, salaries, eliminated. As Reuters project manager Anthony De Rosa told the New York Times's David Carr, Habermas's fear of refeudalization has come to pass. "The land many live on is owned by someone else, be it Facebook or Twitter or Tumblr, or some other service that offers up free land and the content provided by the renter of that land essentially becomes owned by the platform that owns the land" (Carr, 2011). With the growth of the ranks of underemployed professionals and hobbyists who will work for free, professional freelancers have seen their annual incomes slip by as much as 50 percent. One California freelancer told the Los Angeles Times that she once earned $\$ 70,000$ a year and now has to hustle to earn half that (Rainey, 2010). Mutter says 
he worries about "journocide," that an entire generation may be lost, as journalists turn to other jobs (ibid.).

With newspapers and TV news outlets being strapped for cash, this has led to an opening for government and business to tell their own stories, unfiltered, under the guise of real journalism. Newspapers have long known that a cheap way to fill an op-ed page was with commentary from politicians and leaders of industry - usually written by communications staffers. For example, government departments regularly provide video "news" bits promoting their activities. A lot of it is harmless - pieces on drug policy or agriculture research, for example - and simply promotional material that, were it labelled as such, could be taken by the viewer as one facet of the story. However, as local TV news finds itself with fewer staff and often growing airtime, the pressure has increased to fill the air with something that at least looks like a local newscast. As a result, even items that come with identification are edited to "simply identify the government 'reporter' as one of their own" (Barstow \& Stein, 2005).

In Canada, there have been several complaints about the way the government of Stephen Harper has exercised control over the media by limiting access and centralizing communication in the hands of a few top-ranked ministers - to the point that Ottawa Citizen science writer Tom Spears wrote that, when an earthquake struck western Quebec in 2010 , he had to go to U.S. Geological Survey for comment, because "no one at Natural Resources Canada, which runs the earthquake office, was answering." In the end, days later, he filed a Access to Information request for information, and received "a big heavy box" filled with email printouts (Spears, 2010). If Natural Resources Canada is that fearful of commenting on a routine act of God, we can only imagine to what else 
Canadians are being denied access.

The Prime Minister's Office has even taken to controlling the flow of photographs, and this has preyed upon understaffed newspaper photo desks. For example, in October 2009, a picture of Stephen Harper playing piano in rehearsal for a National Arts Centre gala was sent out, mislabelled as being from the performance that took place later in the day, and run as such by newspapers across the country. Earlier that year, photographers were kept at such a distance from the prime minister when he was on a tour of the Arctic that the national wire service had to rely on handouts from the PMO to send to Canadian newspapers (Chase, 2009). News organizations have charged that "the PMO has effectively set up its own picture service," and is marketing publicity shots as news photos (ibid.). The situation was so tense at one point that Canadian news organizations published an open letter complaining that "transparency is replaced by slick propaganda and spin designed to manipulate public opinion" (Banerjee, 2010).

It's easy to see where all this is headed if newsroom staffs continue to shrink and freelancers find themselves getting more desperate to earn a living. For one thing "a journalist who is fearful that he can't get another job is in a weaker position to refuse to do something ethically questionable ..." (Jones, 2009: 105). For another, it will become harder for news organizations to demand high ethical standards of writers they're refusing to pay. "Lower standards are cheaper than high standards" and, if writers have to hustle for a living, "don't blame them for getting bought" (Poniewozik, 2009). Huffington Post blogger Michelle Haimoff once put up a posting that suggested bloggers could make money by promoting the products of advertisers (Carr, 2009). Jessica Smith, who once ran a consumer-advice blog called JessicaKnows.com was known for accepting favors from 
the people she reviewed, like the Ford motor company, which gave her use of a Flex after she reviewed the vehicle. "I prefer not to be critical," she told the New York Times (ibid.). There are numerous examples of consumer advocates-some of whom appear on national talk shows reviewing children's products - who are shilling for corporate interests. But where things get more worrisome is in the area of political blogging and activism. As we have seen with James O'Keefe and ACORN and Andrew Breitbart and Shirley Sherrod, even political activists who believe they're fighting for a good cause can be responsible for misinformation and broken lives. When news organizations are eager for cheap, easy, sensational items, the combination can be frightening. For example, when President Barack Obama nominated Sonia Sotomayor for the U.S. Supreme Court, almost instantly, identical highly contentious - and as it later turned out highly edited-footage of the candidate surfaced on all the TV newscasts. The footage was not the work of newspeople, but of "political hit men."

With journalists being laid off in droves, savvy political operatives have stepped eagerly into the breach. What's troubling is not that TVnews producers mistake their work for journalism, which is bad enough, but that young people drawn to journalism increasingly see no distinction between disinterested reporting and hit-jobbery. The very smart and capable young men ... who actually dug up and initially posted the Sotomayor clips both originally described themselves to me as part-time aspiring journalists (Bowden, 2009).

There is also a distinct possibility that the best quality impartial news may become an elite resource. In some cases specialty publications and newsletters with narrow focus and/or an agenda are stepping in to fill the gap left in political coverage by newspapers. As of 2009, Climate Wire had more staffers covering Washington than Hearst newspapers (Kurtz, 2009). And the business press, such as the Wall Street Journal, Bloomberg and Reuters, are "news organizations that not only are healthy 
but are on a hiring spree" (Moses, 2012). Bloomberg employs some 2,400 editorial staff, an increase of 300 hundred since 2009 , and Thomson-Reuters has hired 600 journalists in four years (ibid.). As Adweek pointed out, the growth of organizations that make most of their money from subscription-only financial information, raises some troubling questions. These companies do not produce "public-interest journalism" but rather news that "is geared to making, as one critic puts it, 'a handful of people even richer" " (lbid.).

Finally, there is the question of how we can be sure a political blogger who has attracted a following may not decide to cash in by selling that following to corporate or political sponsors. In the spring of 2012 , a California government commission proposed a bill that would force political bloggers to reveal their funding. "Bloggers say they develop a contract with readers based on what they write, and it doesn't matter who is funding their speech" but "it's fair for all of us to wonder what they're hiding" (Houpt, 2012b).

For the foreseeable future, at least, it looks as if it is going to get progressively more difficult to discern who is telling us what, and why. 


\section{Conclusion Post-postmodern times}

IN 2000, when he was touring to promote his book, What Are Journalists For? Jay Rosen began a guest lecture at Carleton University by saying that the single biggest threat to journalism was the big media company. That was the prevailing sentiment among many, if not most, media critics at the time. The feeling was that: journalism would have a hard time surviving the business practices of the big conglomerates; it would be much better for the craft if the chains were to be broken up, and the business put back into the hands of people who cared-specifically, journalists, their audiences and local owners. Clear out the empire builders. Pay down debt. Lower profit expectations to reasonable levels. Stop working for short-term monetary gain and build a business for the future. To a sub-group of these critics, which included Rosen, the call for reform also involved doing something about the remove from society at which journalists operate. To proponents of civic journalism, the business needed to re-establish itself as part of the conversation of the culture. To again invoke Dahlgreen's summary, cited by Deuze in Chapter 5, this means: "reformulating the relationship between the press and the people ... establishing connections and contacts between journalists and the communities they cover trying to address the audience as equal partners instead of 'just' consumers ... a focus on issues instead of institutions." As Deuze points out, this also could be taken as a formula for effective online journalism (1999: 385-386).

At the time of writing it is $12 \frac{1}{2}$ years later, and most of those big media companies continue to hold on, for the most part to the detriment of journalists and 
their audiences, but to the great economic benefit of a few, highly paid executives. They also have tended to dominate the discussion about the state of the business since the Great Recession that began in 2008 , and that has severely limited the scope of the conversation, at least in terms of real, practical measures to bring the industry into the 21 st century.

One of the few hopes that the recession held out was that the big newspaper chains would collapse and shatter into a host of small, local publishing companies, while also leaving holes for new enterprises to fill. This almost happened in Canada, with Canwest. Unfortunately, instead of being broken up into several regional newspaper clusters - as investors in British Columbia, the Prairies and Ontario tried to make happen - the newspaper part of the company went into yet another leveraged buyout, and another corporate name: Postmedia. As for Postmedia's "digital-first" slogan, so far, this appears simply to mean business as usual: more debt payments, more layoffs, thinner products, more readers turning away, and the hope that digital journalism will reveal a new revenue model-involving little physical infrastructure and fewer salaried employees. In the United States a similar but more desperate scenario has played out with the Tribune company. At the time of writing, Tribune has been in Chapter 11 bankruptcy protection for $3 \frac{1}{2}$ years and, if there is an exit strategy, it has yet to be revealed. There, too, it has been business as usual, but with much larger bonuses.

At the same time, big media conglomerates continue to converge, controlling more and more of the market share. In Canada almost all private English television is controlled by three companies, Rogers, Shaw and Bell, which are also satellite and 
cable delivery companies. In New Brunswick, the print media is nearly 100 percent run by one company. In its home province, Quebecor dominates the medianewspapers, magazines, cable, mobile phones, the largest independent TV station. Through its Sun Media subsidiary, it is the largest newspaper publisher by title in Canada. This is a company that has ruthlessly slashed jobs at Sun Media, reduced its flagship Quebec dailies to ghosts of their former selves and is clearly in the process of harvesting small newspapers across Canada, leaving dozens of small communities with little in the way of community information. In the United States, some newspaper chains are "strip-mining" their properties, to use David Carr's term (2011), and drawing obscene executive bonuses (ibid.). More than anything, the behaviour of many of these companies resembles looting. Yet, to the detriment of craft and community, they hang on, like Rasputin. You can poison them, stab them and shoot them, and they stay on their feet drinking until there is nothing left to consume. The worst thing about this is that they occupy valuable space in the public sphere that might be better used by organizations with some kind of journalistic vision, as opposed to nothing more than a profit strategy that doesn't work.

One of the more pernicious and overlooked effects of the chains' trouble has been the way it has fashioned the conversation. As Franklin (2008), Picard (2010) and Chyi, Lewis \& Zheng (2011) have pointed out, the discourse has been "Manichaean" (Franklin), Western-focused (Picard), and short-term, lacking in context, and too closely aligned with the views of newspaper management (Chyi, Lewis \& Zheng). The lengthy history of concern about chain ownership, the growing chasm in outlook, interest and priorities between journalist and audience, the crisis in management, the 
fact that circulation had been falling since the mid 1940s and young people had turned away, the focus on personalities, institutions and the rich and powerful: these all had been identified as problems within the industry long before the "broken business model" and the "perfect storm." In some cases, the concern stretched back as far as 60 years, and through inquiries in the United States, Canada and Britain that had identified serious problems in the business. At least one, Canada's Kent Commission, had proved tremendously prescient in its identification of the dangers of concentration of ownership. Another, the Hutchins Commission in the United States, had helped define both the role of a newspaper in society and the terms of discussion for the fulfillment of that role.

As for the stress between the desires of the powerful and the needs of the people, that conversation has been going on since Plato and Aristotle. And, as Gramsci (1971) Williams (1978) and Habermas (1989) have warned, there will always be forces fashioning the message to make the receivers more docile and amenable to the interests of the sender. The question always has been how to control those stresses without stifling a free press, as with government control, or handing strategic communicators and opportunists another tool, as with formulae such as the Social Responsibility Theory of the press. Until now, a libertarian philosophy of news has proved to be the least of all available evils in that it produces a reasonably diverse media that plays by a set of rules that, though they tend to reinforce the status quo, never actually present a threat to public security, personal freedom or free speech. As Gitlin says, there are "five wolves" at journalism's door. Three of them have been at the centre of the recent discussion: falling circulation, dwindling 
advertising revenue and increased competition for the public's attention. The other two have been all but forgotten: a severe "crisis of authority" and "journalism's inability or unwillingness to penetrate the veil of obfuscation behind which power conducts its risky business" (2009). All five of those wolves have been scratching to get in for a very long time.

THE PART of the business that has been hit hardest by the recession in North America has been the local mid- to large-city omnibus daily. These newspapers have traditionally relied on three streams of revenue-display advertising, classifieds and circulation - and they have made disastrous decisions that have undermined the last two. Their display advertising base had been eroded by old media, such as television and its various offshoot specialty and cable channels. Now, it is under attack by new media. Newspapers went online believing that the Internet would work for them the way broadcasting worked for radio and television: they would be able to spend little to attract a large audience and then they could sell that audience for large advertising dollars. However, they overlooked an important detail: on the Web, there are no broadcast licences and no set number of frequencies, so competition is unlimited. The Internet has spawned new ways for sellers to reach customers, ranging from direct sales sites such as Amazon and the various book chains, to embedded messages in search-engine results, to Facebook and Twitter campaigns, to buying discounted unsold ad space for a fraction of its original value. Data mining also has enabled advertisers to target their messages to special classes of customer, often to the individual, and can even direct consumers to the nearest places where they can buy 
what they need or want. All of this has limited the appeal of addressing commercial messages to a mass audience. As we saw in Chapter 4, newspapers advertisements have become "the patent-leather stilettos of the online world: they get used for special occasions ..." (Clifford, 2009a). That, more or less, means national advertisers will use traditional outlets for brand building, for institutional advertising. However, for the big retail campaigns, where the results add up at the cash register, they aim their money very carefully. Also, as Mutter (2012b) points out, the big newspaper companies are running true to their history of misreading technology, in their inability to apply new advertising technology to their readers.

At the same time, newspapers have lost-some would say, "have given away"- their advantage in classified advertising. Television was not at all adaptable to transmitting classifieds, so newspapers had long had that highly lucrative area of the business to themselves, and that had helped sustain revenue. When they overlooked such services as Craigslist and Kijiji, and failed to reimagine classifieds for the online world, they gave away the store.

Finally, though its importance has been minimized in recent years, circulation revenue provided a third stream of income that had one virtue display and classified advertising did not. So long as a newspaper was able to hold onto its readers, this was money that could be counted on regardless of the state of the economy. By choosing to give away their product online, newspaper owners created the weird situation that the more popular they were, the less profitable they became. At the same time, newspapers failed to see the quite obvious fact that if you follow the belief that information is free, people are going to feel free to take it. As we have seen, that is 
exactly what aggregators have done, often to great profit for the aggregator and zero income for the newspapers. Also, since aggregators have had the liberty to pick and choose their content, they usually have been able to put together more interesting products than individual dailies could.

The consequences of all these actions have been that, of the newspapers' three revenue streams, one, display advertising, is coming under increasing competition, as well as increasing pressure to lower value; the second, classified advertising, has almost completely dissipated; and the third, circulation, has been cannibalized by aggregators and the papers' own online product.

DESPITE ALL this, there have, in fact, been several bright spots in the business: small community papers and chains who run them as if they matter, such as Warren Buffett's new Berkshire Hathaway publishing group in the United States, and Glacier and Black in Canada; newspapers that are independent or close to it, such as the Globe and Mail, the New York Times, the Seattle Times, the Dallas Morning News, the Winnipeg Free Press and Brandon Sun and the Halifax Chronicle-Herald; the British national papers, especially the Guardian, Telegraph and Daily Mail; the U.S. newspapers' Sunday editions, which comprise the one area of growth in mid-size to large markets and are responsible for a third to half of some papers' revenue (PEJ, 2012); and almost everywhere outside the English-speaking world.

Smaller North American dailies have benefited from their closeness to their communities, the lack of competitors like Craigslist or alternative news sites, and in many cases, the fact that they charge for their online content. For the most part, the 
small dailies and community newspapers have managed to secure all three areas of revenue.

The large, national newspapers, such as the Wall Street Journal and New York Times in the United States, the Globe and Mail in Canada and the Guardian, the Telegraph, and the Daily Mail in the U.K. have used the Internet to create national and in some cases international reach that has extended their brands almost immeasurably. Some are losing money at an alarming rate, and whether they will be able to monetize these large audiences remains to be seen. However, the fact that they are experimenting with news-gathering and presentation and, in some cases, storytelling, as well as new ways to make money, indicates that they have long-range vision.

In Britain, there is no doubt the stronger competition and more fiery brand of journalism have helped keep the national dailies alive, but that doesn't mean that the British papers are immune to the factors affecting newspapers elsewhere in the English-speaking world. Like their counterparts in North American, British papers have lost classified advertising and paid circulation to the Internet. The Times group was among the first large papers to go behind a paywall, and it was a disaster. The Guardian, supported by its Scott Trust-ownership, is focused strongly on an open Internet strategy, and has a powerful interest in developing technology for new forms of story-telling and fact-gathering. Although it has more than 9 million readers in print and online (Halliday, 2012), it has reported losses some $£ 44.2$ million for 2012 (Sabbagh, 2012b). Meanwhile, the Telegraph and Daily Mail have strong print and Internet strategies that have kept them competitive, but they, too, have reported 
dropping profits.

Newspaper readership has been growing in such countries as China, India, Brazil and Argentina. One argument is that increased literacy is fueling readership, and that may apply to India, but it falls apart when you try to apply it to a developed country like Argentina, or to China, where the middle class is the prime driver of the move toward free expression. Similarly, to say that people read newspapers because they lack the Internet is to ignore the fact that the Internet is well established in large segments of Chinese, Brazilian and Argentine societies. In fact, due to technological leapfrogging, many developing countries have superior infrastructure to the older, established ones in developed nations.

Finally, the success of the Sunday papers indicates that there is still a market for print, if it is handled properly. One thing that always seems non-negotiable in discussions about the state of newspapers is the word "daily." Yet, it seems newspapers that claim they want to rebrand themselves as news companies should be making selective use of all available platforms. Again, there is an either-or attitude at work: online or print. Why not online and print? Some newspapers are looking at publishing just online on days of the week when all they have to sell is breaking news, and printing on days when they have big advertising sections, or specialty products for which print is better suited. For example, the big Sunday (in Canada, Saturday) papers are an aesthetic and tactile experience that would never translate very well to digital media - and they need to be shared, which you can't do with a tablet. Similarly, the Thursday city tabloid, with its reviews, features, city news and listings is something you can fold or roll up and stuff in a pocket, and then spread out on a restaurant table, so you can argue with friends about what to do for the evening. One overlooked virtue of print is that it is disposable. It is also more difficult to censor and control than the Internet and may prove to be the answer to government attempts to control information flow, such as China's Great Firewall. 
In North America, the business is being hollowed out. The mid- to largemarket omnibus dailies have very limited appeal outside their market areas and face increased competition at home from online blogs and news sites, city weeklies, tabloid give-aways and myriad alternative options for advertisers. They also have been hobbled by the demands of servicing their parent companies' debts and meeting shareholder expectations for high profit margins. This has led to severe cutbacks in staff and the quality of the product. So, whether they have the resources, or even the will and imagination to recreate themselves for various platforms is highly debatable.

SINCE the struggles of the chains and their properties have mainly dominated the discourse over the past four years or so, their point of view has defined much of the discussion about technology. As we have seen, technology has been a powerful driver in the development of both the business and the craft of journalism over the ages. The invention of moveable type brought the news from the church pulpit to the living rooms and coffee houses of the world, and transformed oral culture into a literate one. The postal system allowed mass delivery of newsletters and newspapers. The better postal systems got, the greater the frequency of delivery and the wider the reach. The rise of literacy and the invention of the steam press created a mass audience and a means of mass production, and the working and living conditions of the immigrant classes created a need for populist and muckraking reporting. The telegraph allowed papers to print overnight news. Radio created a medium in which the powerful could talk directly to the powerless, and news could be transmitted almost instantaneously. TV added pictures, putting the viewer on the scene of great events. Cold type, photo 
engraving and offset printing made production easy, cheap and simple, and enabled the explosion of the underground press in the late ' 60 s, leading indirectly to the brief return to literary journalism and muckraking in the 1970 s, and opening up a world of graphic design ideas that is still unfolding today.

Because of the focus on "broken business models" and "perfect storms" a great deal of the current conversation has revolved around technology as the destroyer of worlds or the saviour that will wash away all corporate sins. So, the largest part of the conversation has been devoted to debating subscription vs. metered paywalls or pondering whether the digital tablet will bring people back to buying the daily paper. However, as we have seen, technology is once again shaping the way we gather information, tell stories and deliver them. Television news and Newspaper Web sites are experimenting with audio, video, slide shows, interactive graphics, even adapting video-game technology to news reporting; almost all sites are using comment fields to both involve readers in the conversation of the culture and to tap into public opinion, and some are finding ways to incorporate user-generated content into their news package, especially at the "hyper-local" level; sites such as Open.File (which has, unfortunately, under severe financial pressure, closed down to reorganize) and GroundReport are dependent on their readers for either story ideas and raw information or even wiki-reporting; wikileaks has created a new outlet for whistle blowers and leakers; the blog has opened up the conversation to anyone with an axe to grind or a cause to fight for.

This has created a cacophony of opinion, fact and manufactured "truthiness" that has made the public landscape more difficult than ever to navigate. Observers 
such as Barney (2004), Deibert (2002) and Norris (2000-2001) have talked about the Internet as more of a "bonding" than "bridging" technology, about its ability to draw like-minded people together around topics of mutual interest, and the fact that, online, people are no more likely to be engaged or unengaged than they are in real life. There is some evidence that bonding behavior is combining with talk radio and partisan allnews television to help create a highly polarized style of politics. This somewhat undermines the Utopian view that the online world is a Deweyan ideal of public discourse, and print is Lippmann's intelligence service. A popular theory of the two spaces has the Internet as Milton's free market of ideas, in which the strongest and best ideas will survive, and print as a Hobbesian agent of the sovereign, purifying the conversation so that it is washed clean of all metaphor, equivocation, eloquence and absurdity.

As it turns out, that's a highly simplistic idea. As Williams and Habermas have warned, idealism and cynicism have the effect of leaving the door wide open for the manipulators and opportunists who would use communication strategically and for personal gain. And there is probably more strategic communication on the Internet than Ideal Speech Situation. We have seen this with such incidents as the ACORN sting and the subsequent phone-tapping attempt, and partisan attacks on government officials that use video out of context to manufacture controversy. As Bowden (2009) points out in Chapter 6, the frightening thing about the acceptance of this use of technology is that for many young people going into journalism, this kind of ideological crusading has become something to which they aspire.

In the end, it would appear that there definitely is a place on the Internet for 
the daily newspaper, but not necessarily in its current form, and that journalists have more to gain by embracing crowd sourcing, user-generated content and aggregation than by fighting them or pretending they don't exist. With the masses of information, opinion and misinformation filling the Internet, the mainstream media could provide a useful function by monitoring, mapping and moderating this organic network of communication - but newspapers are unlikely to be successful if they continue with their current practices of talking at their readers rather than with them.

WITH ALL the focus on the "broken business model," the conversation about a broken journalism model has been obscured. As a consequence, the solutions all seem to focus on the question, " 'How do we get money for what we've always done?' rather than, 'How do we provide something worth paying for?' " (Schaffer, 2009) Most of the plans to revitalize journalism have looked at finding new ways to fund the same old sins. For example, it's not surprising that Schudson would concentrate on preserving the functions of the press regardless of whether it has an audience. He has long argued that Lippmann was right about the public's limited ability to comprehend public affairs, and that the press serves a valuable function in simply being ready to bark when the powers that be get out of line (1995). It's predictable that McChesney would argue for a government-sponsored press, when much of his past criticism has involved the evils of chain ownership (1999). We expect Rosen to push the online Deweyan ideal, because of his association with Carey and his history with civic journalism (1999).

In this, Rosen has a bit of an edge because, as Deuze points out, the principles of civic journalism are most easily transferred to the Web. However, there is a disconcerting 
tendency among most commentators to wipe away decades of press criticism, when they buy into one side or the other of the argument surrounding online and mainstream journalism. There's a "Next year in Jerusalem" fantasy connected to much Internet theorizing. All the sins will be forgiven; all financial problems will sort themselves out; all the underemployed will get raises and the unemployed will find jobs; all humans will be equal; we'll raise up the temple and the conversation of the culture will ring out through the land.

But the conversation on the Internet is unlikely to be much improved over the one we've been having in print, at least not as long as the same, stuffy editorial judgment, near-sightedness and rigid definitions of the spheres of consensus, controversy and deviance continue to be applied by journalists with little or no empathy for their readers. Similarly, newspapers that have cut newsrooms to the bone and filled their products with safe, advertiser-friendly news are unlikely to be able to compete, or to build desirable brands online, where the competition is much more rough and tumble, aggressive and entertaining. As Tofel (2012) pointed out by invoking Stewart Brand, bad information is initially as valuable as good information. It is only when a source has proved itself to be reliable, trustworthy and worth our time that it gains value over other sources of information. If newspapers are to survive, they are not going to be able to do it by following current practices, and they are going to have to invest in journalism.

This brings us back to Gitlin's five wolves. In the end, the most destructive will likely prove to have been the crisis in authority. Though there have been wonderful examples of newspapers that are evolving to survive, there are more of chain-bound dailies that are suffering cutback after cutback, shackled to servicing parent companies' 
debts, or in the hands of myopic or cynical owners who are "only serious about cashing in as many chips as possible before closing time" (McChesney \& Nichols, 2010: 14).

One thing that should be self-evident is that creating bureaucracy to issue journalists' cards and restrict access to the craft to so-called "professionals" represents just another facet of the panic prose that has dominated much of this discourse. What may be the most interesting thing about Andrew Cohen's attack on Amanda Lindhout (Chapter 6) is the fact that, like so many other commentators, he completely misses the point on his three main issues: Novels and politics are open to anyone who wants to prove she has the talent to tackle them, as is journalism. In all three fields, performance is the only measure of success and all three pursuits are the better for it. As we have seen, much of the criticism of daily newspapers is that there often isn't a lot of difference between them and advertising flyers. And young people know the Daily Show isn't news, because it doesn't talk down to them, it mostly deals with issues, and it ridicules the people they think are ridiculous.

However, the resentment towards the Daily Show is predictable coming from a member of a press that feels it does not get the respect or reverence it deserves, and blames its audience. That last point may be the most telling weakness revealed by the discussion about the business: too much of it centres on whether the audience has a short attention span, a disinterest in civic life or is too drawn to entertainment, and not enough on whether the mainstream media is speaking a language its audience understands, or cares to. As Williams (1983) pointed out, the best weapon the masses have to use against the powerful is their sullenness. We are powerless to tear down what we don't like, but we can tune it out - with a vengeance. It is probably safe to say that the news industry is in no 
position to preach to its audience, when it has managed to mess up such major stories as the sale of the war in Iraq to the American people, the financial manipulations that toppled the world economy or, in Canada, the erosion of democracy by a government with little respect for free speech.

It cannot be stressed enough that the conversation needs to avoid tripping into the extreme of condemning the "lamestream press." Almost all the criticism going back to Lippmann has been made within the belief that there is a strong need in a free society for some kind of fourth estate. Perhaps there may be more need now than ever for a neutral public meeting place, an Agora, where society can come together not just for politics, but to celebrate culture, share knowledge and understanding and try to create that elusive Great Community. This demands bridging technology and, when most of the Internet is about bonding, newspapers are in a position to fill a need.

We have a long tradition in believing that open communication is a natural state for humanity, and that censorship and repression, despite their omnipresence, are deviant. At the same time, the concern over the ability of special interests to bend communication to their will also stretches back hundreds of years. From Hobbes and Burke to Lippmann, Habermas and Williams, there has been a legitimate fear that persuasive speakers can combine with an uninformed audience to create tyranny or chaos-that today's majority has the power "to deprive tomorrow's majority of its rights" (Lippmann, 1963: 56). At the moment, a free press is the best tool we have to protect against this, but it needs to evolve. As Alan Rusbridger (2010) pointed out, there is a middle ground. We can have highly skilled and dedicated professional journalists working with passionate, intelligent and well informed readers to create something new and exciting and, in all likelihood, stronger than 
what we had before. And the sooner the big media companies get out of the way and let it happen, the better.

Lest that last note be interpreted as the typical cold-hearted dismissal of the Internet enthusiast for the thousands of professional journalists being thrown out of work, we should remember that what is bad for big media isn't necessarily bad for journalism. Many journalists who have lost their jobs are underemployed, struggling to earn a freelance living in a market where the value of their work is plummeting. Many are downgraded to reduced or part-time wages, or out of the business altogether. However, even in this there are bright spots. Non-profit organizations dedicated to investigative journalism are being formed; alternative news sites are springing up in many cities and some, like the underground papers of the 1960s and '70s, are doing more interesting and harder hitting journalism than dailies with which they are competing; and the concept of hyper-local journalism has created thousands of entrepreneurial opportunities for journalists who want to be their own bosses and give a voice to their communities. Organizations such as Gannett and Quebecor are busily working on creating the need. And recent research (Grueskin et al., 2011) has indicated that the Internet may finally be cracking open to reveal some treasures that are available to the average businessperson. Despite its reputation for shortening attention spans, digital technology is even proving a boon for literary journalism, as some storytellers have discovered they can market long investigative features directly to their audience, via electronic readers and tablets. A recent example is Paula Todd's Finding Karla, a 46-page e-book the Toronto journalist wrote about tracking down serial killer Karla Homolka, which she marketed through the Internet. 
Perhaps the one thing that has been most overlooked in the conversation of the crisis in newspapers is that journalists may have let themselves down by being too little involved in the business of their business. If executives who don't understand the craft comprise the biggest threat to journalism, it may be fair to say Threat No. 2 is made up of journalists who don't understand the business side of their industry. A good part of the future will belong to entrepreneurial journalists who find a way to make their craft work across media, and can demand a fair price for it. 


\section{Bibliography}

Adam, G. Stuart. 2006. "Notes Towards a Definition of Journalism." Journalism: The Democratic Craft. G. Stuart Adam and Roy Peter Clark eds. New York and Oxford. Oxford University Press.

Adams, Larry L. 1977. Walter Lippmann. Boston, Twayne Publishers.

Adams, Richard. 2011: "Huffington Post Sold to AOL for $\$ 315 \mathrm{~m} . ”$ The Guardian. Feb. 7 .

Adams, Russell \& Lublin, Joann S. 2010. “Michaels Resigns as Tribune CEO.” Wall Street Journal. Oct. 23.

Adams, Russell and Ovide, Shira. 2009. "Publishers See End of Freefall in U.S. Ad Sales." Globe and Mail. Jan. 4.

Adams, Russell, Ovid, Shira \& Simon, Stephanie. 2009. "Rocky Mountain News Folds Amid Ad Slump." Wall Street Journal. Feb. 27.

Advertising Age. 2011. "New York Times Introduces BETA620, a Public Site for Its Experimental Projects." Aug. 7.

Agence France-Presse. 2009. "Future of Newspapers is Digital: Murdoch.” May 28.

- 2011. "Newspapers to Disappear by 2040: UN Agency Chief." Oct. 3.

Alterman, Eric. 1982. Sound \& Fury: The Washington Punditocracy and the Collapse of American Politics. New York. Harper Collins.

- 2008a. "Out of Print: The Death and Life of the American Newspaper." New Yorker. March 31.

- 2008b. "I Read the News Today ... Oh Boy." The Nation. Aug. 4.

- 2009a. "Save the News, Not the Newspaper." The Nation. Feb. 11.

- 2009b. "Lose the 'Business'; Save the 'News.'" The Nation. April 27.

Altheide, David L. 1984. "Media Hegemony: A Failure of Perspective." Public Opinion Quarterly, 48 no. 2: 476-490.

Andrews, Robert. 2011. "Case Study: Newspapers Writing for Search Trends." paidContent.org. 2011.

Armstrong, Paul. 2009. "Behind the Incredible Shrinking Media." Businessweek. March 10.

Associated Press and Context-Based Research Group. 2008. A New Model for News: Studying the Deep Structure of Young-Adult News Consumption. A Research Report.

Atrios. www .eschatonblog.com. Accessed July 28, 2012.

Austen, Ian. 2010. "Globe and Mail Uses Old Weapons in Press War." New York 
Times. Oct. 24.

Australian, The. 2010. "Newspapers Gone by 2022, Says Futurist.” Aug. 24.

Avery, Sinom. 2010. "Bloodletting in U.S. Newspaper Industry Slows to a Trickle."

Globe and Mail. July 26.

Bagdikian, Ben. 1990. The Media Monopoly. Fourth Edition. Boston. Beacon Press.

- 2004. The New Media Monopoly. Boston, Beacon Press.

Bailly, Nestor. 2009. "Dallas Morning News 'Draws a Line in the Sand' Regarding Cuts, Fights Back with Quality.” editorsweblog.org. (World Editors Forum).

Oct. 12.

Baker, Sir Ernest. 1948. Social Contract, Essays by Locke, Hume and Rousseau. New York and London. Oxford University Press.

Ball, James. 2012: "Paul Dacre's Press Accreditation Plan Should Be Struck Off." The Guardian. Feb. 8

Banerjee, Sidhartha. 2010. “Journalists Decry Harper Gov't PR Control.” Canadian Press. June 10.

Barney, Darin. 2004. The Network Society. Cambridge, Polity Press.

Barstow, David \& Stein, Robin. 2005. "Under Bush, a New Era of Prepackaged News." New York Times. March 13.

Bates, George. 2010. "Cut This Story!" Atlantic Monthly. January-February.

Bauder, 2012). "Tablets Drawing More People to News, but News Industry May Not Profit from It." Toronto Star. March 19.

Behling, Ellie. 2010. "How Publishers Are Making News More Personal." eMedia Vitals. Sept. 2

Bell, Jocyln. 2000. "The British Are Coming, the British Are Coming: How Fleet Street Stormed Front Street and Colonized the Globe and Mail." Ryerson Review of Journalism. Summer.

Benhabib, Seyla. 1989. “Models of Public Space: Hannah Arendt, the Liberal Tradition and Jurgen Habermas." Habermas and the Public Sphere. Craig Calhoun ed. Cambridge, Mass., and London, MIT Press.

Bercovici, Jeff. 2010. Times of London Paywall Paying Off Already*." Forbes. Dec. 3.

- 2012. "Gannett Building Paywalls Around all Its Papers Except USA Today." Forbes. Feb. 22.

BETA620.nytimes.com.m Accessed July 17, 2012.

Bimber, Bruce. 1998. "The Internet and Policy Transformation: Populism, Community and Accelerated Pluralism." Polity 41, no. 1: 133-160.

Bird, Roger. 1997. The End of News. Toronto, Irwin. 
Birmingham Post. 2009. "Midland Newspapers Group Collapse Signals Bleak Times Ahead." March 16.

Blakemore, Steven. 1984. "Burke and the Fall of Language: The French Revolution as a Linguistic Event." Eighteenth-Century Studies 17, no. 3: 284-307.

Bledstein, Burton J. 1976. The Culture of Professionalism: The Middle Class and the Development of Higher Education in America. New York, W.W. Norton \& Co.

Blethan, Ryan. 2009. "Recession Could Fuel New Era of Local Newspaper Ownership." Seattle Times. June 12.

Botelho, Stephanie. 2012. "The New York Times, The Daily and New Yorker Top Performing Titles on Apple's Newsstand." Folio. Jan. 13.

Bowden, Mark. 2009. "The Story Behind the Story." Atlantic Monthly. October.

Bridge, Sarah. 2009. "Pasages to India: If Outsourcing Copy Editing Saves the Odd Daily, Is It so Bad." Ryerson Review of Journalism. June.

Briggs, Asa, and Burke, Peter. 2005. A Social History of the Media: From Gutenberg to the Internet. Second edition. Cambridge. Polity.

Brown, Tina. 2008. "Kill the Media Zombies." Daily Beast. Dec. 8.

- 2010. "Things to Stop Bitching About in 2010." Daily Beast. Jan. 3.

Bundy, Jeff, 2011. "Buffett on Newspapers: 'Enormously Useful Product." Omaha World-Herald. Dec. 4.

Bunz, Mercedes. 2010. "In the U.S., Algorithms Are Already Reporting the News." The Guardian. March 30.

Calhoun, Craig. Ed. 1992. Habermas and the Public Sphere. Cambridge, Mass, and London, MIT Press.

canada.com. Accessed July 18, 2012.

Canadian Media Research Consortium (CMRC). 2004. Report Card on Canadian News Media, www.cmrcccrm.ca/english/index.html.

- 2008. The Credibility Gap: Canadians and Their News Media Five Years Later. cmrcccrm.ca/english/index.html.

- 2011, "Canadian Consumers Unwilling to Pay for News Online." cmrccrm.ca/english/index.html.

- 2011. "Even in the Digital Era, Canadians Have Confidence in Mainstream Media." cmrcccrm.ca/en/projects/documents/CMRC_Trust_Report_11May.pdf.

Canadian Press. 2000. Hollinger Profit Jumps 24 Percent," Feb. 18.

- 2005. "Newspaper Profit Margins Declined in 2005." Dec. 6

- 2011. "Readers Migrate Between Newspapers, Online Sources, NADbank Study Finds." Sept. 28.

Carey, James. 1997a. "The Chicago School and the History of Mass Communication 
Research." James Carey, a Critical Reader. Eve Stryker Munson and Catherine A Warren eds. Minneapolis, University of Minnesota Press.

- 1997b. "A Republic, if You Can Keep It: Liberty and Public Life in the Age of Glasnost." James Carey, a Critical Reader. Eve Stryker Munson and Catherine A Warren eds. Minneapolis, University of Minnesota Press.

- 1997c. "Communications and Economics." James Carey, a Critical Reader. Eve Stryker Munson and Catherine A Warren eds. Minneapolis, University of Minnesota Press.

- 1997d. "The Press, Public Opinion and Public Discourse." James Carey, a Critical Reader. Eve Stryker Munson and Catherine A Warren eds. Minneapolis, University of Minnesota Press.

Carper, Alison, 1997. "Marketing News." Politics and the Press: The News Media and Their Influences. Pippa Norris ed. Boulder and London, Lynn Rienner.

Carr, David. 2009a. "Nonprofit Journalism: Not Necessarily on the Cheap." New York Times. Sept. 30.

- 2009b. "Newspapers Essential Strengths." New York Times. May 4.

- 2009c. “After a Year of Ruin, Some Hope." New York Times. Dec. 21.

- 2010. “At Flagging Tribune, Tales of a Bankrupt Culture." New York Times. Oct. 5

- 2011a. "At Media Companies, a Nation of Serfs." New York Times. Feb. 13.

- 2011 b. "At Gannett, Furloughs but Nice Paydays for Brass." New York Times. April 10.

- 2011b. "Why Not Occupy Newsrooms." New York Times. Oct. 23

- 2011d. “When Truth Survives Free Speech.” New York Times. Dec. 11.

Carr, Paul. 2010. "A Death of a Thousand Hacks: New Forbes Editorial Genius in Bold Plan to Kill Forbes." Techcrunch.com. June 14.

Carter, Bill \& Stelter, Brian. 2010. "In 'Daily Show' Role on 9/11 Bill, Echoes of Murrow." New York Times. Dec. 26.

CBC.ca. 2010. “Toronto Star, Union Strike Deal.” Jan. 18.

- 2011. "Canadians Prefer News Online, but Only for Free." April 13.

Chase, Stephen. 2009. "What's Wrong with These Pictures." Globe and Mail. Nov. 7.

Chittum, Ryan. 2009a. "Circulation Revenue Only Thing Growing at Newspapers. Columbia Journalism Review. July 23.

- 2009b. "NYT Now Gets as Much Money from Circulation as from Ads." Columbia Journalism Review. July 23.

- 2010a. "Parsing the Latest Online-Charging Poll." Columbia Journalism Review. Jan. 14. 
- 2010b. "Newsday Paywall Is Barely Affecting Local Traffic." Columbia Journalism Review. Jan. 28.

- 2012a. "The New York Times Company in 2015." Columbia Journalism Review. April 18.

- 2012b. "Paywalls: Maybe Not So Complicated After All." Columbia Journalism Review. Jan. 17.

Chomsky, Noam. 1989. Necessary Illusions, Thought Control in Democratic Societies. Boston, South End Press.

Chozick, Amy. 2012. "New York Times Co. Posts $\$ 88$ Million Loss, Citing About.com Write-Down." New York Times. July 6.

Chyi , Hsiang Iris, Lewis, Seth C. and Zheng, Nan. 2011. "A Matter of Life and Death?" Journalism Studies. Vol. 13 no. 3.

Clark, Nick. 2011. "Daily Mail Profits Fall 15 Per Cent as Papers Come Under Pressure." The Independent. Nov. 24.

Clifford, Stephanie. 2009a. "Online Rally May Sidestep Newspapers." New York Times. Oct. 26.

Cohen, Noam and Stelter, Brian. 2010. "Iraq Video Brings Notice to a Web Site." New York Times. April 6.

Cohen, Noam. 2008. "Reluctantly, a Daily Stops Its Presses, Living Online." New York Times. April 28.

- 2010. "What Would Daniel Ellsberg Do with the Pentagon Papers Today?" New York Times. April 18.

Cohen, Andrew. 2009. "Journalism's Amateur Hour." National Post. Dec. 3.

Colbin, Kaila. 2011. "Shoptalk: The Value of User-Generated Content." Editor \& Publisher. May 31.

Commager, Henry Steel. 1950. The American Mind: An Interpretation of American Thought and Character Since the 1880's. New Haven, Yale University Press.

completure.com. Accessed July 20.

Compton, James R., \& Benedetti, Paul. 2010: "Labour, New Media and the Institutional Restructuring of Journalism." Journalism Studies. Vol. 11, no. 4.

Cook, Daniel J. 1982. "Marx's Critique of Philosophical Language," Philosophy and Phenomenological Research, 42 (no. 4, June), 530-54.

Cornies, Larry. 2009. "Why the Free Press Still Stands Tall." J-Source.ca. April 11.

Coyne, Andrew. 2008. "How Journalists Got in the Way of the Election." Maclean's. Sept. 29.

Coursey, David. 2012. "You Be the Judge: Are Bloggers Journalists?" Forbes. Jan. 2

Coyle, Jake. 2012 "More than Just Cat Videos: Viewers Now Turning to YouTube for News." Globe and Mail. July 16. 
Craig, Susanne. 1999. "Big papers all Proclaim Survey Victory," Globe and Mail. Oct. 30.

Crawley, Phillip. 1998. "What it takes to Survive: Ever-Tougher Competition Demands an Ever-Stronger Push for Quality Journalism," Marketing, Nov. 16, 1998.

Curran, James and Seaton, Jean. 1997. Power Without Responsibility: The Press and Broadcasting in Britain. Fifth edition. London \& New York, Routledge.

Dailing, Paul. 2009. "How to Become a 'Death of Newspapers' Blogger." Huffington Post. March 25.

Darnton, Robert. 2009. The Case for Books. New York. Public Affairs.

- 2010. Poetry and the Police: Communication Networks in Eighteenth Century Paris. Cambridge, Mass., London. Belknap,

Davey, Keith et. al.1970. The Uncertain Mirror: Report of the Special Committee on Mass Media. Vol. 1. Ottawa, Information Canada.

Davies, David R. 2006. The History of American Journalism: The Postwar Decline of American Newspapers, 1945-65. Westport, Conn., London. Praeger.

Deibert, Ronald, J. 2002. "Circuits of Power: Security and the Internet Environment." Information Technologies and Global Politics. Albany, SUNY.

Deuze, Mark. 1999. "Journalism and the Web: An Analysis of Skills and Standards in an Online Environment." International Communication Gazette. Volume 61, no. 5: 373-90.

- 2004. "What Is Multimedia Journalism?' Journalism Studies. Volume 5, no. 2: 139-52.

- 2007. Media Work. Cambridge: Polity.

Dewey, John.1954. The Public and Its Problems. Athens, Ohio, Swallow Press/University of Ohio Press.

- 1985. "Review of Public Opinion by Walter Lippmann." John Dewey: The Middle Works 1899-1924. Vol. 13, 1921-22, 337-344. Edited by Jo Ann Boydston, Carbondale, Il. Southern Illinois University Press. Orig. 1925.

Diana, Alison. 2011. "Twitter Trends Driven by Mainstream Media." InformationWeek. Feb. 16.

Didion, Joan. 2006a. "Insider Baseball." Political Fictions. We Tell Ourselves Stories In Order to Live, Collected Nonfiction. New York, London \& Toronto, Everyman's Library. Orig. 2001.

- 2006b. "The White Album." The White Album. We Tell Ourselves Stories In Order to Live, Collected Nonfiction. New York, London, Toronto, Everyman's Library. Orig. 1979.

- 2006c. "A Preface." Slouching Towards Bethlehem. We Tell Ourselves Stories In Order to Live, Collected Nonfiction. New York \& London, Toronto, Everyman's 
Library. Orig. 1968.

- 2006d. "Why I Write." Journalism: The Democratic Craft. G. Stuart Adam, Roy Peter Clark eds. New York, Oxford, Oxford University Press.

Dornan, Christopher. 2006 "Big Media, Bad Thing." Literary Review of Canada. December.

- 2012: "Newspapers and Magazines: Of Crows and Finches." Cultural Industries.ca: Making Sense of Canadian Media in the Digital Age. Ira Wagman and Peter Urquhart eds. Toronto, Lorimer.

Domingo, David. 2011. "Managing Audience Participation: Practices, Workflows and Strategies." Participatory Journalism: Guarding Open Gates at Online Newspapers. Malden, Mass \& Oxford, Wiley-Blackwell.

Downie Jr., Leonard and Schudson, Michael. 2009. The Reconstruction of American Journalism. Columbia Journalism Review. Oct. 20. www.cjr.org

Drew, Jill. 2010. "The New Investigators." Columbia Journalism Review. May-June.

Duffy, Andrew. 2010. "Algonquin Launches GoJournalism.ca." Ottawa Citizen. Sept. 25.

Dumenco, Simon. 2009. "Trashy Parasitism as a Get-Rich-Quick Scheme? Hi HuffPo." Advertising Age. June 22.

- 2009b. "How the Big Gulp Approach to News Makes Readers Scram: What Happens When the Product You Produce Literally Makes People Feel Bad About Themselves." Advertising Age. Jan. 19.

Ebner, David. 2009. "Hope on the Horizon." Globe and Mail. July 27.

Economist, The. 2008. "Not All Bad News: Newspapers Are Thriving in Many Developing Countries" July 24.

Edmonton Sun. 2000. "Record earnings posted at Quebecor," Feb. 9.

Editors, The. 2008. "Our Lapdog Media." The Nation. May 19.

Edmonds, Rick. 2009. “Shrinking Newspapers Have Created \$1.6 Billion News Deficit." Poynter Online. Oct. 10.

- 2010. "Seven Reasons Newspapers Are Not Rebounding Financially." Poynter Online. Nov. 15.

Eisenstein, Elizabeth. 1979. The Printing Press as an Agent of Change. Cambridge, New York, Melbourne. Cambridge University Press.

ethicsscoreboard.com/list/freeping.html. Accessed July 18, 2012.

Evans, Martin. July 28, 2012. "Phone Hacking: Full List of Charges." The Telegraph. July 28.

Ewing, Jack. 2008. "Where Newspapers Are Thriving." Businessweek. Aug. 11.

Fallows, James. 2010. "How to Save the News." Atlantic Monthly. June. 
Farhi, Jim, 2012. "New Orleans Times-Picayune to Limit Printing to Three Days per Week." Washington Post. May 24.

Fetherling, Douglas. 1990. The Rise of the Canadian Newspaper. Toronto, Oxford University Press.

Financial Post. 2012a. “Postmedia Network Announces Cost Transformation Plan. July 11 .

-2012b. "Postmedia Newspapers to expand Online Subscription Model." April 12.

Fink, Conrad C. 1996. Strategic Newspaper Management. Boston, Allyn and Bacon.

Fitzgerald, Mark. 2009. "New Study Shows Strong Newspaper Readership in Canada's Big Cities.” Editor \& Publisher. Sept. 23.

- 2010a. "Times-Picayune Super Bowl Victory Edition Sells 50,000-plus Copies." Editor \& Publisher. Feb. 8.

- 2010b: "Fireworks at Journal Register Co: 'Ben Franklin Project' Successful at All 18 dailies." Editor and Publisher. July 6.

Flam, Matthew. 200. "WSJ Publisher Calls Google 'Digital Vampire.'” www.crainsnewyork.com. June 24.

Flavelle, Dana. 2010. "Postmedia Raring to Go, Godfrey Says.” Toronto Star. July 22.

Flavelle, Dana \& Spears, John. 2010. "Shaw Buys Control of Canwest Global." Toronto Star. Feb. 12.

Flock, Elizabeth. 2012. “Are Syrian Citizen Journalists Embellishing the Truth. Washington Post. blogPOST. March 27.

Foley, Stephen, 2008. “Tribune's \$13bn Debt Sends It Spiralling into Bankruptcy." The Independent. Dec. 9.

Foremski, Tom. 2010. "The Rise of Page View Journalism." www .zdnet.com. May 25.

Franklin, Bob. 2008. "The Future of Newspapers.” Journalism Studies, Volume 9, no. 5 .

Friend, David. 2009. "Star Announces Major Restructuring." Toronto Star. Nov. 3.

- 2009. "Papers Could Fetch \$1-Billion: Analyst." Globe and Mail. Oct. 16.

Fritz, Ben. 2010. "Most Original News Reporting Comes from Traditional Sources, Study Finds.” Los Angeles Times. Jan. 11.

Garnham, Nicholas. 1992. "The Media and the Public Sphere." Habermas and the Public Sphere. Craig Calhoun ed. Cambridge, Mass., and London, MIT Press.

Gatehouse, Jonathan. 2009. "The Short End of the Canwest Stick." Macleans. Oct. 20.

Gazette, The. 2008. "Union at Journal de Québec Votes to Settle 15-Month Lockout." July 3. 
Geary, James. 2006. "In Praise of the Tabs (Sort of)." British Journalism Review. 17, no. 1.

Geary, Joanna. "Paul Dacre's Old Media Thinking Threatens Citizen Journalism." The Guardian. Feb. 8.

Gerard, Warren. 2005. "He Made His Mark on City and Nation." Toronto Star. Nov. 9.

Gitlin, Todd. 2009. "Journalism's Many Crises." www .opendemocracy.net. May 25.

Gladwell, Malcolm. 2010. "Small Change: Why the Revolution Will Not Be Tweeted." New Yorker. Oct. 4.

Glessing, Robert J. 1970. The Underground Press in America. Bloomington \& London, University of Indiana Press.

theglobeandmail.com. Accessed July 18, 2012.

Globe and Mail. 2009. "Canadian Newspapers See Rise in Readership." Sept. 24.

- 2010. "Editorial Autonomy and Financial Acumen." Sept. 10.

- 2012. "Quebecor's Sun Media Cutting 400 Jobs: Union." Mar 14.

GoJournalism.ca. Accessed July 29, 2012.

Goodale, Gloria. 2010. "Colbert-Stewart Rally Raises Question: Where is Journalism Headed." Christian Science Monitor. Oct. 21.

Gottdiener, M. 1985. "Hegemony and Mass Culture: A Semiotic Approach." American Journal of Sociology, 90, no. 5.: 979-1001.

Gramsci, Antonio. 1971. Selections From the Prison Notebooks. New York, International Publishers.

Greenslade, Roy. 2012: "Gannett's Profits Plunge by 33\% The Guardian. Feb. 2.

Greisling, David. 2008. "Tribune Co.'s Crisis Has Been Years in Making." Chicago Tribune. Dec. 9.

Gross, Daniel. 2009. “Paper Hangers.” Slate. Oct. 28.

groundreport.com. Accessed July 19, 2012.

Grueskin, Bill, Seave, Ava \& Graves, Lucas. 2011. The Story So Far: What We Know About the Business of Digital Journalism. New York, Columbia Journalism School Tow Center for Digital Journalism.

Guardian, The. 2011. "History of the Guardian: A Brief History of the Guardian Newspaper." www.guardian.co.uk. Oct. 28.

Guss, Donald L. 1991. "Enlightenment as Process: Milton and Habermas." PMLA, 106, no. 5.: 1156-1169.

Gustin, Sam. 2011. "Murdoch's News Corp. Launches the Daily for Apple's iPad." Wired. Feb. 2.

Hackett, Robert A. and Zhao, Yuezhi. 1998. Sustaining Democracy: Journalism and 
the Politics of Objectivity. Toronto. Garamond Press

Habermas Jurgèn. 1989. "The Public Sphere." Jurgën Habermas on Society and Politics. Steven Seidman ed. Boston, Beacon Press.

- 1991. The Structural Transformation of the Public Sphere: An Inquiry Into a Category of Bourgeois Society. Cambridge, Mass., MIT Press.

- 1992. "Further Reflections on the Public Sphere." Habermas and the Public Sphere. Craig Calhoun ed. Cambridge, Mass., and London, MIT Press.

Hallin, Daniel C. 1989. The Uncensored War: The Media and Vietnam. Berkeley and Los Angeles. University of California Press.

Hallman, Eugene, Oliphant, P.F. and White, R.C. 1981. The Newspaper as a Business" Research Studies on the Newspaper Industry. Royal Commission on Newspapers.

Halperin, Mark. 2010. "The Media Spiral: From O.J. to Sherrod." Time. July 26.

Hambleton, Paul. 2009. "Dealing with User-Generated Content: Is It Worth It?" The Future of Journalism: Papers from a Conference Organised by the BBC College of Journalism. Charles Miller ed. London, CoJo Publications.

Harden, 2011. "MediaNews Group to Launch Online Paywall for Papers in 5 States." Denver Business Journal. Aug. 13.

Harkness, Ross. 1963. J.E. Atkinson of the Star, Toronto, University of Toronto Press.

Hayes, David. 1992. Power and Influence: The Globe and Mail and the News Revolution. Toronto Key Porter.

Herman, Edward S. and Chomsky, Noam. 1988. Manufacturing Consent. New York, Pantheon Books.

Hermida, Alfred. 2011. "Mechanisms of Participation: How Audience Options Shape the Conversation." Participatory Journalism: Guarding Open Gates at Online Newspapers. Malden, Mass \& Oxford, Wiley-Blackwell.

- 2011. "Fluid Spaces, Fluid Journalism: The Role of the 'Active Recipient' in Participatory Journalism," Participatory Journalism: Guarding Open Gates at Online Newspapers. Malden, Mass \& Oxford, Wiley-Blackwell.

Hernandez, Marco. A., District Judge. 2011. Opinion. Obsidian Finance Group, LLC, and Kevin D. Padrick v. Crystal Cox. United States District Court, District of Oregon, Portland Division. Nov. 30.

Hiar, Corbin. 2010. "Writers explain What It's Like Toiling on the Content farm." PBS.org. July 21.

Hickens, Michael. 2009. "Internet Isn't Killing Papers, We Are." Faster Times. July 27 .

Hirschorn, Michael. 2009. "End Times." Atlantic Monthly. Jan.-Feb.

Hobbes, Thomas. 2001. The Leviathan. Classics of Moral and Political Theory, 
Michael L. Morgan ed.

Hockenberry, John. 2005. "The Blogs of War." Wired. April.

Honderich, Beland. 1999. "How One Man's Crusade Changed Our Lives.” Toronto Star. Dec. 13.

Hood, Duncan. 2008. “Could Canwest Go Bankrupt?” Maclean's. Dec. 22.

Horkheimer, Max and Adorno, Theodore W. 1972. "The Culture Industry:

Enlightenment as Mass Deception." Dialectic of Enlightenment. John Cumming trans. London, New York. Verso.

- 2002a. "The Concept of Enlightenment." Dialectic of Enlightenment. Edmund Jephcott trans. Stanford, Calif., Stanford University Press.

Houpt, Simon. 2012, “A Seasoned David Gergen Decries Today's Pop-Up Pundits. Globe and Mail. March 16.

House of Lords Select Committee on Communications (Lords). 2008. The Ownership of the News. London. The Authority of the House of Lords.

Hutchins, Robert M. et al. 1966. "A Free and Responsible Press: Report of the Commission on Freedom of the Press." The Responsibility of the Press. Gerald Gross ed. New York. Fleet.

Huxley, Joan. 2012. "The Herald to Go Tabloid as Fairfax Cuts 1900 Jobs." Sydney Morning Herald. June 19.

Iquateman. 2009. “Wiki Journalism.” New York Review of Ideas. June.

Jackson, Joseph. 1999. Newspaper Ownership in Canada: An Overview of the Davey Committee and Kent Commission Studies. Public Works and Government Services Canada, Political and Social Affairs Division.

Johnson, Gene. 2009. “Could Seattle Become a No-Newspaper Town?” Associated Press. March 14.

Jones, Alex S. 2009. Losing the News: The Future of the News that Feeds Democracy. Oxford, New York. Oxford University Press.

Kamiya, Gary. 2009. “The Death of the News.” Salon.com. Feb. 17.

Kaplan, David. 2011. "NAA: Newspapers Have Had 20 Quarters of Consecutive Ad Rev Declines." paidContent.org. Sept. 2.

Katz, Elihu and Foulkes, David. 1962. "On the Use of the Mass Media as 'Escape': Clarification of a Concept." Public Opinion Quarterly, 26, no. 3: 377-388.

Kaufmann-Osborne, Timothy. 1984. "John Dewey and the Liberal Science of Community." Journal of Politics, 46, no. 4: 1142-1165.

Kawamoto, Dawn. 2009. "Online newspaper readership climbs 16 percent." Cnet.com

Kelly, Michael. 2000. "Demystification: A Dialogue between Barthes and Lefebvre," Yale French Studies, no. 98, 79-97. 
Kent, Tom. 1981. Royal Commission on Newspapers. Ottawa: Supply and Services Canada.

- 1996 "The Times and Significance of the Kent Commission," Seeing Ourselves: Media Power and Policy in Canada, Helen Holmes and David Taras eds. Toronto: Harcourt Brace Jovanovich.

Kesterton, W.H. 1984. A History of Journalism in Canada. Ottawa, Carleton University Press.

Kinsman, Matt. 2010. "November Issue Is Biggest Revenue Generator in The Atlantic's 153-Year History." Folio. Oct. 12.

Kirchner, Laura. 2011. "John Paton's Big Bet." Columbia Journalism Review. JulyAugust.

Kirby, Jason. 2010. "A Lord Resurrected: Legal Vindication, Yes, but More Surprising, Some of Conrad Black's Harshest Critics Admit They Were Too Quick to Judge." Maclean's. Dec. 13.

Krashinsky, Susan. 2009. "Good News Hard to Find at U.S. Papers." Globe and Mail. Oct. 22.

- 2010a. "Canadian Dailies Losing Few Readers, Figures Show." Globe and Mail. April 24.

- 2010b. "Why Carnage on the Newsstand is Giving Way to Cautious Optimism." Globe and Mail. May 15.

- 2011a. "Job Cuts to Save Postmedia up to \$35 Million." Globe and Mail. Jan. 6.

- 2011 b. "Postmedia sells Victoria Times-Colonist to Glacier Media." Globe and Mail. Oct. 18.

Kurtz, Howard. 2009. "As Mainstream Exits D.C., Niche Media Tide Rises" Washington Post. Feb. 11

- 2010a. "In Journalism's Crossfire Culture, Everyone Gets Wounded." Washington Post. Aug. 2.

- 2010b. "Mindless March of the Media Herd." Washington Post. Aug. 23.

Ladurantaye, Steve. 2012a. "Postmedia Signs three-year Deal with Canadian Press." Globe and Mail, May 7.

- 2012b. "Globe to Charge Readers for Online Content. May 10.

-2012c. Postmedia Cuts More jobs, Sunday Editions." Globe and Mail, June 18.

Lakshman, Nandini . 2008. "Copyediting? Ship the Work Out to India." Businesweek. July 8.

Lanham, Richard A. 2006. The Economics of Attention: Style and Substance in the Age of Information. Chicago. The University of Chicago Press.

Lasch, Christopher. 1991. The True and Only Heaven: Progress and Its Critics. New York, W.H. Norton. 
Layton, Charles. 1999. "Tea Leaves," What Do Readers Want? State of the American Newspaper.

Levine, Josh. 2009. "Turning the Page: The News on Europe's Newspapers.” Time. Feb. 19.

Levine, D.M. 2011. "Small Papers Lead the Way on Paywalls." Adweek. June 3.

Lewis, Jemima. 2007. "There Is a Thin Line Between Respectable and Supinè, and U.S. Journalism Is on the Wrong Side." The Independent. June 30.

Lewis, Paul. 2011. "Crowdsourcing the News." Video. www.ted.com/talks/paul_lewis_crowdsourcing_the_news.html

Liedtke, Michael. 2009a. "San Francisco Chronicle in Danger of Folding." Huffington Post. Feb. 25.

- 2009b. "Small Is Becoming Beautiful for Many Newspapers in U.S." Associated Press. Aug. 15.

- 2009c. "Survey Finds America's Crumbling Trust in the News Media's Accuracy Hits a 24-Year Low." Associated Press. Sept 13.

- 2009d. "SF Chronicle Goes Glossy to Attract Readers, Ads." Associated Press. Nov. 4.

Linkins, Jason. 2009. “Online Poll: Jon Stewart Is America's Most Trusted Newsman." Huffington Post. Sept. 9.

- 2010. "Poverty Rate Report: The Day the Media Cared About the Poor." Huffington Post. Sept. 17.

Lippmann, Walter and Merz, Charles. 2007. "A Test of the News." Killing the Messenger. Tom Goldstein ed. New York. Columbia University Press. Orig. 1920.

Lippmann, Walter. 1931. "The Press and Public Opinion." Political Science Quarterly 46, no. 2: 161-170.

- 1955. Essays in the Public Philosophy. New York, New American Library.

- 1963a. "Why Should the Majority Rule?" The Essential Lippmann: A Political Philosophy for a Liberal Democracy. New York, Random House. Orig. 1926.

- 1963b. "The Higher Law" from The Good Society. The Essential Lippmann: A Political Philosophy for a Liberal Democracy. New York, Random House. Orig. 1926.

- 1978. Drift and Mastery. Westport, Conn., Greenwood Publishers. Orig. 1914.

- 1993. The Phantom Public. New Brunswick, N.J., Transaction Publishers. Orig. 1937.

- 1997. Public Opinion. New York, Free Press Paperbacks.

Orig. 1922.

- 2008. Liberty and the News. Princeton and Oxford. Princeton University Press. 
Orig. 1920.

Lodish, Emily. 2011: "Gaddafi's End: How Cell Phones Became Weapons of Choice." Global Post. Oct. 21.

Lynch, Lisa. 2010. "We're Going to Crack the World Open." Journalism Practice. Vol. 4, no. 3 .

Lyons, Daniel. 2009a. "Exterminate the Parasites: A Radical Plan to Save Old Media." Newsweek. Sept. 14.

MacAfee, Michelle. 2000. "Newspapers not keeping up with technology, analyst says." Canadian Press, May 11.

MacPhail, Wayne. 2001. "Content? No Thanks!" Rabble.ca, Oct. 22.

Maffin, Tod. 2011. Interview with the author, for the CBC Doc Zone presentation, "Are We Digital Dummies." May.

Mak, Tim. 2011. "Pew: Opinion of Media Never Worse." Politico. Sept. 23.

Manjoo, Farhad. 2009. "The Newspaper Isn't Dead Yet." Slate. June 18.

Marlow, Iain. 2010. "BCE-CTV Deal Remakes Media Landscape." Globe and Mail. Sept. 10.

Martin, Lawrence. 2003. "It's not Canadians' Who've Gone to the Right, Just Their Media." Globe and Mail. Jan. 12.

- 2009. "To Save Journalism, Bring on that Jon Stewart Outrage." Globe and Mail. March 19.

- 2011. "Has the Fourth Estate Lost Its Tenacity?" Globe and Mail. May 24.

McArthur, Keith. 2000. "It's All in the Delivery," Globe and Mail. April 29.

McCann, Nick. 2011. "Investigative Blogger Must Pay \$2.5 Million." Courthouse News Service. March 29.

McChesney, Robert. 1999. Rich Media, Port Democracy: Communication Politics in Dubious Times. Urbana, Chicago. University of Chicago Press.

McChesney, Robert and Nichols, John. 2010. The Death and Life of American Journalism: The Media Revolution that Will Begin the World Again. Philadelphia, Nation Books.

McGinniss, Joe. 2011. Rogue: Searching for the Real Sarah Palin. New York, Crown.

McGlinn, Katie. 2011. ' 'Huffbert Nation': HuffPost's Answer to the 'Colbuffington Re-Post.'" Huffington Post, Feb. 18.

McLaren, Leah. 2010. “A Globetrotting Canuck Journo Aims to Revolutionize Online News." Globe and Mail. May 7.

McNair, Brian. 2000. Journalism and Democracy: An Evaluation of the Political Public Sphere. London, New York, Routledge. 
McNish, Jacquie and Krashinsky, Susan. 2011. "The Glitch in Postmedia's Digital Switch." Globe and Mail, Sept. 29.

McPherson, James Brian. 2006. Journalism at the End of the American Century, 1965-Present. Westport, Conn., London, Praeger.

Meares, Joel. 2011. "Confidence in TV News and Newspapers (Slightly) Up. Columbia Journalism Review. June 28.

Meek, James Gordon. 2010. "FBI: ACORN Gotcha Guy Busted for Bugging Landrieu." Daily News. Jan. 26

de la Merced, Michael J. 2008. "Tribune Files for Bankruptcy." New York Times. Dec. 8

Merrill, John C., Nerone, John C. 2002. "The Four Theories of the Press Four and a Half Decades Later: A Retrospective." Journalism Studies 3, no. 1, January: 133134.

Meyer, Phillip. 1999. "Remember When the Media's Mission Was to Ferret Out Truth, Not Gossip?" USA Today. Sept. 1.

Miller, John. 1998. Yesterday's News: Why Canada's Daily Newspapers Are Failing Us. Halifax, Fernwood.

Mills, C. Wright. 2000. The Sociological Imagination. New York, Oxford University Press. Orig 1959.

Mills, Russell. 2003. "Canwest Plan a Threat to Local Independence." Globe and Mail, Jan. 22.

Milton, John. 1644. Areopagitica. darkwing.uoregon.edu.

Mindworksglobal .com. "About Us." Accessed July 7, 2012.

Minsky, Amy. 2010. "Trust in Professionals Is on the Wane: Poll-Canadians Give Soldiers Top Marks." Postmedia News. Dec. 28.

Moozakis, Chuck. 2009. "Papers Hope Web Holds Key to Future." Newspapers \& Technology. April.

Morales, Lyman. 2010. "In U.S., Confidence in Newspapers, TV News Remains a Rarity." Gallup.com. Aug. 13.

- 2012. "U.S. Distrust in Media Hits New High." Gallup.com. Sept. 21.

Moroney, James W. III. 2010. "Newspaper Companies That Survive Will Not Consider Themselves Newspaper Companies." Poynter Online. Oct. 1.

Morrison, Jennifer. 2003. "Pharmacists, Doctors, Pilots 'Most Trustworthy,' Survey Says," Ottawa Citizen, Jan. 12.

Morton, John. 2008. "It Could Be Worse." American Journalism Review. www.ajr.org

- 2011. "Costly Mistakes." American Journalism Review. www.ajr.org 
Mosco, Vincent. 1996. The Political Economy of Communication. London, Thousand Oaks, Calif, Sage.

- 2003. The Digital Sublime: Myth, Power and Cyberspace. Cambridge, Mass., MIT Press.

Moulins, Joe. 2002. A Tribe of His Own: The Journalism of P. Sainath. Documentary Film. Bullfrog Films.

Mutter, Alan D. 2009. "Mission Possible? Charging for Web Content." Reflections of a Newsosaur (newsosaur.blogspot.com). Feb. 8.

- 2011. "Newspaper Ad Sales Head to New Low: \$24B." Reflections of a Newsosaur (newsosaur.blogspot.com). Dec. 5.

- 2012a. "Newsroom Staffing Hits 34-year Low." Reflections of a Newsosaur (newsosaur.blogspot.com). April 4.

- 2012b. "Newspapers Getting Outsmarted on Mobile." Sept. 4.

Myers, Steve. 2010. "New York Times Embraces Collaborative Journalism with CUNY Hyperlocal Experiment.” Poynter Online. Jan. 16.

NADbank. 2011.2011 Study. Newspaper Audience Databank Inc.

Nader, Laura. 1997. "Controlling Processes: Tracing the Dynamic Components of Power." Current Anthropology, 38, no. 5.: 711-737.

Neil, Janice. 2011. "Quebec Journalists Approve Idea of 'Professional Journalist' Card." The Tyee. April 13.

Nerone John C. et al. 1995. Last Rights: Revisiting Four Theories of the Press. Urbana \& Chicago. University of Illinois Press.

Newspaper Guild. 2006. "Salary Info." $\mathrm{ttp}: / / \mathrm{www}$.newsguild .org/salary/2006reporterstart.php

New York. 2010. "Tom Brokaw Agrees with Tina Brown: Young People Should Just Move to India." Oct. 10.

www.nytimes.com. 2008. "Casualties of War." /ref/us/20061228_3000FACES_TAB2.html. Jan. 12.

- 2008. "The Lourdes of Twang" /packages/html/travel/20080222_MARTIN_FEATURE. Feb. 22.

- 2008. "The Collapse Sequence."

interactive/2008/03/15/nyregion/20080315_CRANE_GRAPHIC.html. March 15.

- 2011. "The Reckoning." /interactive/us/sept-11-reckoning/viewer.html. Undated.

New Republic. 2009. "MSM RIP.” March 4.

Newspapers Canada. 2012. "Ownership." www .newspaperscanada.ca/ownership. Accessed July 25, 2012.

Noelle-Neumann, Elisabeth. 1993. The Spiral of Silence: Public Opinion, Our Social 
Skin. Second edition. Chicago and London, University of Chicago Press.

Nordland, Rod. 2012. "Ghastly Images Flow from Shattered Syrian City." New York Times. Feb. 22.

Norris, Pippa et al. 1999. On Message: Communicating the Campaign. London, Thousand Oaks, Calif., Sage.

Norris, Pippa. 1997. Politics and the Press: The News Media and Their Influences. Boulder, Colo., London, Lynn Rienner.

- 2000. A Virtuous Circle: Political Communications in Postindustrial Societies. Cambridge, Cambridge University Press.

- 2001. Digital Divide: Civic Engagement, Information Poverty and the Internet Worldwide. New York, Cambridge University Press.

- 2002. Democratic Phoenix: Reinventing Political Process. Cambridge, Cambridge University press.

- 2003. "Preaching to the Converted." Party Politics 9, no.1: 21-45.

- 2004. "The Bridging and Bonding Role of Online Communities." Society Online: The Internet in Context. Philip N. Howard and Steve Jones eds. Thousand Oaks, London. Sage.

Nussbaum, Emily. 2009. "The New Journalism: Goosing the Gray Lady." New York. Jan. 11.

O'Shea, James. 2011. The Deal From Hell: How Moguls and Wall Street Plundered Great American Newspapers. New York, Public Affairs.

Olive, David. 2009. "My stubborn Faith in Newspapers." thestar.blogs.com/davidolive (Toronto Star). Oct. 19.

Oneal, Michael \& Rosenthal, Phil. 2008. "Tribune Co. Files for Bankruptcy." Chicago Tribune. Dec. 9.

OpenFile.ca. Accessed July 17, 2012.

Oppmann, Patrick. 2009. "Seattle Post-Intelligencer Prints Final Edition in Online Transition." CNN.com. March 16.

Ortiz, Christina. 2012. “Citizen Journalism App Inspired by Arab Spring. Discovery News. April 17.

Ovide, Shira \& Adams, Russell. 2009. “As Decline Grips Big U.S. Dailies, Investors Rush to the Small Towns." Globe and Mail. April 28.

Paper Cuts. 2012. "Layoffs and Buyouts at U.S. Newspapers"' (Totals: 2007-2012). newspaperlayoffs.com/maps/2007-layoffs.

Park, Robert E. 1975. "The Crowd and the Public." The Crowd and the Public and Other Essays. Chicago, University of Chicago Press. Orig. 1904.

Paton, John. 2012. "Another Tough Step." jxpaton.wordpress.com. Sept. 5.

Patterson, 2009. "Buffett Sees Unending Losses for Many Newspapers." Wall Street 
Journal, May 2.

Paulussen, Steve. 2011. "Inside the Newsroom: Journalists' Motivations and Organizational Structures." Participatory Journalism: Guarding Open Gates at Online Newspapers. Malden, Mass \& Oxford, Wiley-Blackwell.

Pérez-Peña, Richard. 2008. "Newspapers: A Hot Commodity After Obama's Win." New York Times. Nov. 6.

- 2009a. "Seattle Paper is Resurgent as a Solo Act." New York Times. Aug. 10..

- 2010a. "It's Official: 2009 Was Worst Year for Newspaper Business in Decades." New York Times. March 24.

- 2010b. "Poll Finds Pessimism Among Print and Broadcast Journalists." New York Times. April 11.

Peters, Jeremy W. 2010. "Not on His Watch: USA Today Founder Says." New York Times. Aug. 30

- 2011 a. "Carlos Slim Adds Stake in Times Company." New York Times. Aug. 23.

- 2011b. "Times's Online Pay Model Was Years in the Making." New York Times. March 20.

Peters, John Durham. 1989. "Democracy and American Mass Communication Theory: Dewey, Lippmann, Lazarsfeld." Communication II: 199-220.

- 1995. "Historical Tensions in the Concept of Public Opinion." Public Opinion and the Communication of Consent. Theodore L. Glasser and Charles T. Salmon eds.

- 2003. "Retroactive Enrichment: Raymond Williams's Culture and Society." Canonic Texts in Media Research: Are There Any? Should There Be Some? How About These? Elihu Katz, John Durham Peters et al eds. Cambridge, U.K., Polity

- 2005. Courting the Abyss: Free Speech and the Liberal Tradition. Chicago and London, University of Chicago Press.

Pew Research center. 2008. "Internet Overtakes Newspapers as News Source." pewresearch.org/pubs

- 2009. "Stop the Presses? Many Americans Wouldn't Care a Lot if Local Papers Folded." Pewresearch.org/pubs/1 147/newspapers-struggle-public-not-concerned

- 2010. "Facebook Is Becoming Increasingly Important." journalism.org/analysis_report/facebook_becoming_increasingly_important. May 9.

Pfanner, Edward. 2009a. "European Newspapers Find Creative Ways to Thrive in the Internet Age." New York Times. March 30.

- 2009b. "French Papers Aim at Younger Readers." New York Times. Oct. 28.

- 2010. "In Britain, a Laboratory for Newsprint's Future." New York Times. April 4.

Phelps, David. 2009. "Star-Tribune Files for Chapter 11 Bankruptcy." Minneapolis Star-Tribune. January 16. 
Picard, Robert G. 2008. "Shifts In Newspaper Advertising Expenditures and Their Implications for the Future of Newspapers." Journalism Studies, Volume 9, no. 5 .

- 2010. "A business Perspective on Challenges Facing Journalism." The Changing Business of Journalism and Its implications for Democracy. David A. L. Levy \& Rasmus Kleis Nielsen eds. Oxford. Reuters Institute for the Study of Journalism.

Pincus, Walter. 2009. "Newspaper Narcissism.” Columbia Journalism Review. MayJune.

Pompeo, Joe. 2010. “The Daily Is Murdoch's 'No. 1 Most exciting Project.'” Yahoo! News. Nov. 17.

- 2012. "Times Will End Partnership with NYU, CUNY." Capital. June 26.

Poniewozik, James. 2008. "Doing Less with Less: What Are You Willing to Give Up from Journalism?” Time. Dec. 16.

Popkin, Samuel L. 1991. The Reasoning Voter: Communication and Persuasion in Presidential Campaigns. Chicago and London, University of Chicago Press.

Preston, Peter. 2010. "The Mail's Online Miracle, or How to Get Paid Without a Paywall.” organgrinder blog, guardian .co.uk. July 18.

- 2011. "Will the iPad Tablet Really Be the Cure for Newspapers' Ills?" The Guardian. June 5.

Prichard, Peter. 1987. The Making of McPaper: The Inside Story of USA Today, Kansas City and New York: Andrews, McMeel \& Parker.

Project for Excellence in Journalism (PEJ). 2007. The State of the News Media. stateofthemedia.org/2007

- 2007a. Anna Nicole Smith: Anatomy of a Feeding Frenzy.

- 2008. The State of the News Media. stateofthemedia.org/2008

- 2009. The State of the News Media. stateofthemedia.org/2009

- 2010. The State of the News Media. stateofthemedia.org/2010

- 2011. The State of the News Media. stateofthemedia.org/2011

- 2012. The State of the News Media. stateofthemedia.org/2012

- 2012. "YouTube \& News: News Videos Compared with the Top Videos." July 16.

Pully Brett. 2011. “New York Times Co.'s Boston Globe Begins Charging Readers for Web Access." New York Times. Sept. 12.

Rachman, Gideon. 2009. “American Journalism Still a Model.” Financial Times. July 14.

Rainey, James and Hiltzik, Michael A. 2008. "Tribune Co. Files for Chapter 11 Bankruptcy Protection." Los Angeles Times. Dec. 9.

Rainey, James. 2010. "Freelance' Writing's Unfortunate New Model." Los Angeles 
Times. Jan. 6.

Rainie, Lee, Hitlin, Paul, Jurkowitz, Mark, Dimock, Michael \& Neidorf, Shawn. 2012. "The Viral Kony 2012 Video." Pew Internet and American Life Project. March 15.

Reader's Digest. 2010. “Top Jobs: The Professions We Trust Most." www. readersdigest.ca. April 11.

Reich, Zvi. 2011 . "User Comments: The Transformation of Participatory Space." Participatory Journalism: Guarding Open Gates at Online Newspapers. West Malden, Mass. \& Oxford, Wiley-Blackwell.

Reston, James. 1974. "His Thought and Writings Are Very Much Alive Today." New York Times, Dec. 15.

Reuters. 2011. “Major Papers Launch Online Paid News Service.” Jan. 25.

Riccio, Barry D. 1994. Walter Lippmann: Odyssey of a Liberal. New Brunswick, N.J., Transaction.

Rich, Frank. 2006. The Greatest Story Ever Sold: The Decline of the Truth from 9/11 to Katrina. New York, Penguin.

Riggio, Ronald E. 2009. "Why Jon Stewart Is the Most Trusted Man in America." Psychology Today. July 24.

"RMP." 2010. "Bigger Is Better" comment. Torontosunfamily.blogspot.com. Sept. 10.

Roberts, Jeff. 2012. "Why Warren Buffett is Buying Newspapers.” Time. May 21.

Robertson, Grant and Krashinsky, Susan. 2010. "With Salesman's Touch, Godfrey Claims Canwest." Globe and Mail, May. 11.

Robertson, Grant. 2009. “Canwest Buried Under \$4 Billion." Globe and Mail, Oct. 7.

- 2010. "Canwest Shows No Appetite for Piecemeal Bids." Globe and Mail, Jan. 19.

Robins, Peter. 2010. "The Long, Hard Fall of the Local Press." organgrinder blog, guardian.co.uk. Aug. 25.

Robinson, James. 2010. "Huffington Post Is Among 'News Parasites," says Washington Post Man.” The Guardian. Sept. 23.

Roeder, David. 2009. "Sun-Times Media Group Files for Bankruptcy." Chicago Sun Times. March 31.

Rogers, Everett M. 1997. A History of Communication Study. New York. The Free Press.

Roosevelt, Theodore. 1906. "The Man With the Muck Rake” speech. April 15. www .infoplease .com/ipa/A0900141.html.

Rosen, Jay. 1999. What Are Journalists For? Hartford, Conn., Yale University Press.

- 2006. "The People Formerly Known as the Audience. PRESSthink. journalism.nyu.edu. June 27. 
- 2009. "Audience Atomization Overcome: Why the Internet Weakens the Authority of the Press." PRESSthink. journalism.nyu.edu. Jan. 12.

- 2010. "Fixing the Ideology Problem in Our Political Press: A Reply to Atlantic's Marc Ambinder." PRESSthink. journalism.nyu.edu. July. 22.

Rubenstein, Will, Combe, Liv, Kirkland, Alegra \& Link, Samantha. 2012. "Editorial: Fearless? Not Re: the Internet." Oberlin Review. July 27.

Rusbridger, Alan. 2009. "First Read: The Mutualized Future Is Bright." Columbia Journalism Review.Oct.19. www.cjr.org

- 2010. "The Hugh Cudlipp Lecture: Does Journalism Exist?" guardian .co.uk. Jan. 25.

Saba, Jenifer. 2010. “Times-Picayune, ProPublica, Frontline Launch Joint Project.” Editor \& Publisher." Feb. 15.

Salter, Jim. "Editors See Financial Gains from Cutting Frequency." Associated Press. Oct. 29.

Schaffer, Jan. 2009. "First Read: Follow the Breadcrumbs." Columbia Journalism Review. Oct.19.

Schlesinger, Arthur M. 1959. "Walter Lippmann: The Intellectual v. Politics." Walter Lippmann and His Times. Marquis Childs and James Reston eds. New York, Harcourt, Brace.

Schugurensky, Daniel and Myers, John P. 2001. "Walter Lippmann and John Dewey Debate the Role of Citizens in Democracy." fcis.oise.utoronto.ca/ daniel_schugurensky/assignment1/1922lippdew.html

Schudson, Michael. 1978. Discovering the News: A Social History of American Newspapers. New York, Basic Books.

- 1995. The Power of News. Cambridge, Mass., Harvard University Press.

- 2003. The Sociology of News. New York, Norton.

- 2007. "Lippmann and the News." The Nation. Dec. 31.

- 2008. "The Lippmann-Dewey Debate and the Invention of Walter Lippmann as an Anti-Democrat 1986-1996." International Journal of Communication 2, 1031-1042

Seidman, Steven. Ed. 1989. Jurgen Habermas on Society and Politics. Boston, Beacon Press.

Seattletimes.nwsource.com. Accessed July 17, 2012.

Seattlepi.com. Accessed July 17, 2012

Segar, Mike. 2012. “Buffett Snaps up 63 Newspapers for \$142 million.” Reuters. May 17.

Séguin, Rhéal. 2011. "Vote by Workers Ends Bitter Lockout at Journal de Montreal." Globe and Mail. Feb. 27. 
Seitz, Matt Zoller. 2010. “Why I Like Vicious Anonymous Online Comments.” Slate. Aug. 3.

Selley, Chris. 2009. "Who Died and Made Andrew Cohen the Journalism Gatekeeper?" National Post. Dec. 4.

Shafer, Jack. 2006. "The Tipster in Wolfe's Clothing." Columbia Journalism Review. March-April.

- 2009a. "Not All Information Wants to Be Free." Slate. Feb. 18.

- 2009b. "Democracy's Cheat Sheet: It's Time to Kill the Idea that Newspapers Are Essential for Democracy." Slate. March 27.

- 2009c. “Bring Back Yellow Journalism.” Slate. Match 30.

- 2009d. "Hello Steve Brill, Get Me Rewrite." Slate. April 17.

- 2010a. "Linsky and Lammer Love Long Form. Slate. April 23.

- 2010b. "Death to the Generic News Story." Slate. Oct. 21.

- 2012a. "So Warren Buffett Likes Newspapers Again?" Reuters, May 18.

- 2012b. "How the Byline Beast Was Born.” Reuters. July 6.

Shahid, Sharon. 2011. 2011. "2011 First Amendment Survey: Public Supports Watchdog Free Press." Newseum.Org. July 12.

Shapiro, Ian. 2009. "The Death of Newspapers (Gawker Edition)." Washington Post. Aug. 2.

Shapiro, Michael. 2012. "Six Degrees of Aggregation: How the Huffington Post Ate the Internet." Columbia Journalism Review. June.

Shaw, Lucas. 2012. Newspaper Stocks Freefall in 2011, News Corp. Does Just Fine.” The Wrap Media.

Shirky, Clay. 2008. Here Comes Everybody. London. Penguin Books.

- 2009a. "Newspapers and Thinking the Unthinkable." www. shirky.com. March.

- 2009b. "Not an Upgrade - an Upheaval." www .cato-unbound.org. July 13.

Siebert, Fred S., Peterson, Theodore \& Schramm, Wilbur. 1963. Four Theories of the Press. Urbana \& Chicago. University of Illinois Press.

Simonson, Peter. 2001. "Varieties of Pragmatism and Communication: Visions and Revisions from Pierce to Peters." American Pragmatism and Communication Research. David K. Perry ed. Mahwah, N.J., and London, Lawrence Erlbaum Assoc.

Singer, Jane. 2011. "Taking Responsibility: Legal and Ethical Issues in Participatory Journalism." Participatory Journalism: Guarding Open Gates at Online Newspapers. Malden, Mass. \& Oxford, Wiley-Blackwell.

Smillie, Dirk. 2009a. “Mortimer Zuckerman's \$200 Million Gamble.” Forbes. Aug 7.

- 2009b. “Journalism's Hottest Job." Forbes. Dec. 9. 
Smith, Charlie. 2009. "Vancouver-Based Glacier Media Posts $\$ 28.3$ Million Profit." Straight.com. March 23.

Solomon, William S. (1995) "The Site of Newsroom Labor: The Division of Editorial Practices," Newsworkers: Toward a History of the Rank and File, Hanno Hardt and Bonnie Brennen eds. Minneapolis. University of Minnesota Press.

Sotiron, Minko. 1997. From Politics to Profit: The Commercialization of Canadian daily Newspapers 1890-1920. Montreal, Kingston, Ont., McGill-Queen's University Press.

Spears, Tom. 2010. “Quake Couldn't Shake Loose Government Red Tape.” Ottawa Citizen. Dec. 28.

Spears, Borden. 1984. Borden Spears: Reporter, Editor, Critic, Dick MacDonald ed., Markham, Ont. Fitzhenry \& Whiteside.

Spot.Us. Accessed July 29, 2012.

Starr, Paul. 2004. The Creation of the Media: Political Origins of Modern Communications. New York. Basic Books.

- 2009. "Goodbye to the Age of Newspapers (Hello to a New Era of Corruption)." New Republic. March 4."

- 2010. "Governing in the Age of Fox News." Atlantic Monthly. January-February.

Steel, Ronald. 1980. Walter Lippmann and the American Century. Boston, Little, Brown.

Stelter, Brian. 2011. "Protest Puts Coverage in Spotlight.” New York Times. Nov. 20.

Stephens, Mitchell. 2007. "Beyond the News." Columbia Journalism Review. Jan.Feb.

Stepp, Carl Sessions. 1999. "Paradise Lost." Then and Now, the State of the American Newspaper (the Project for Excellence in Journalism) http.//ajr.newslink.org/special

Stimson, James A., 2004. Tides of Consent: How Public Opinion Shapes American Politics. New York, Cambridge University Press.

Stoeffel, Kat. 2012. "RIP Newscore: News Corp.'s Weird News Wire Goes Dark, Sheds Staff.” New York Observer. July 11.

Storify.com. 2012. Accessed July 6.

Strupp, Joe. 2009a. "Newsday Pay Wall Debuts Today - With Most Stories Behind It." Editor \& Publisher. Oct. 28.

- 2009b. "New York Times R\&D Team Seeks Next Big Things. Editor \& Publisher, Oct. 8.

Sullivan, John. 2011. "True enough: The Second Age of PR.” Columbia Journalism Review. May-June.

Surowiecki, James. 2008. “News You Can Lose.” New Yorker. Dec. 22. 
Sweney, Mark. 2010b. "Times Paywall Goes Up Tomorrow." The Guardian. July 1.

Taras, David. 1999. Power \& Betrayal in the Canadian Media. Peterborough, Ont., Broadview Press.

Taylor, Adam. 2011. "Paywall Fail: Times of London Circulation Collapses as Company's Online Strategy Falters.” Business Insider. June 10.

Teel, Leonard Ray. 2006. The History of American Journalism: The Public Press, 1900-1945. Westport, Conn., London, Praeger.

thestar.com. 2012. Accessed July 18.

Thurber, James. 1974. "Lippman Scares Me Today." New York Times, Dec. 15. Orig. 1935.

Thornton, Emily and Grover, Ronald. 2008. "Sam Zell's Deal from Hell." Businessweek. July 30

Timmons, Heather. 2008. "Newspapers on Upswing in Developing Markets." New York Times. May 20.

Tobaccowala, Rishad. 2010. "Papers Aren't Going Anywhere. Adweek. Sept. 1.

Tofel, Richard, J. 2012. Why American Newspapers Gave Away the Future. Now \& Then iBook.

Toronto Sun Family. torontosunfamily.blogspot.ca. Accessed daily 2007-2012.

Toughill, Kelly. 2008. "Has News Become a Charity Case?” Toronto Star. June 28.

Tsai, Catherine. 2010. "Owner of Denver Post, Salt Lake Tribune Plans Prepackaged Chapter 11 Filing." Associated Press. Jan. 16.

Underwood, Doug. 1995. When MBAs Rule the Newsroom. New York, Columbia University Press.

U.S. Census Bureau. 1999: Statistical Abstract of the United States. "20th Century Statistics." www.census.gov/prod/99pubs/99statab/sec31.pdf

Veblen, Thorstein. 1953. The Theory of the Leisure Class. New York, Penguin Books. Orig. 1899.

Vega, Tanzina. 2010. "Pooling Resources, Two Newsrooms Merge." New York Times. Oct. 18.

Venugopal, Arun. 2008. "Journalist Seeking Paycheck? Try India." Salon.com. Aug. 7.

Vujnovic, Marina. 2011. "Participatory Journalism in the Marketplace: Economic Motivations Behind the Practices." Participatory Journalism: Guarding Open Gates at Online Newspapers. Malden, Mass. \& Oxford, Wiley-Blackwell.

Walton, Mary. 2010. "Investigative Shortfall." American Journalism Review. September.

Watson, Thomas. 2010. “Media War 2.0." Canadian Business. Sept. 13. 
Webbyawards.com. Accessed July 17, 2012.

Week, The. 2010. "'The Media's Risky Paywall Experiment: A Timeline." July 30.

Weingarten, Marc. 2005. The Gang that Wouldn't Write Straight. New York, Three Rivers Press.

Weisenthal, Joseph. 2008. "It's Official: Cablevision Confirms Newsday Acquisition; Acquiring 97 Percent For $\$ 632$ Million." paidContent.org.

Wellborn, Charles. 1969. Twentieth Century Pilgrimage: Walter Lippmann and the Public Philosophy. Baton Rouge, Louisiana State University Press.

Whelan, Frederick G. 1981. "Language and Its Abuses in Hobbes' Political Philosophy," American Political Science Review 75, no. 1: 59-75.

Whitman, Alden. 1974. "Walter Lippmann, Political Analyst, Dead at 85." New York Times, Dec. 15.

Whittaker, Zack. 2011. "UC Davis: Official Spin Crumbles in the Face of 'Too Many Videos.' "ZDNet. Nov. 20.

Willis, Andrew, Krashinsky, Susan and Robertson, Grant. 2010. "New Life for Canwest Newspapers, but Debt Remains." Globe and Mail. May 11.

Wemple, Erik. 2012. "Warren Buffett Buys Newspapers. Is He Nuts?" Washington Post. May 17.

Williams, Raymond. 1978. "The Press We Deserve." The British Press: A Manifesto. James Curran ed. London \& Basingstoke, Acton Society Press Group.

- 1983. Culture \& Society 1780-1950. New York, Columbia University Press.

Wilson, Jeff. 2010. “Analyst's View: Flipboard for iPad is Rupert Murdoch's Nightmare." PC World. Aug. 8.

Wilson-Smith, Anthony. 1998. "A New Embrace: Quebecor Proposes a Friendly Takeover of Sun Media and Pushes Torstar to the Sidelines." Maclean's, Dec. 21.

Wilson, Jeff. 2010. "Analyst's View: Flipboard for iPad is Rupert Murdoch's Nightmare." PC Aug 11.

Winnipeg Free Press. 2011. "Profit Falls for Newspaper Firm," Nov. 12.

Winseck, Dwayne and Cuthbert, Marlene. 1997. "From Communication to Democratic Norms: Reflections on the Normative Dimensions of International Communication Policy." Gazette 59, no 1: 1-20.

Wolfe, Tom. 1973. The New Journalism, Tom Wolfe and E.W. Johnson eds. New York, San Francisco, London, Harper \& Row.

Wolff, Michael. 2009. "Rupert to Internet: It's War." Vanity Fair. November.

World Association of Newspapers and News Publishers." 2009. "Daily News Takes Advantage of New Colour Printing Presses." www.editorsweblog.org/2009.

Wyatt, Nelson. 2002. "Canadian media biased-poll." Canadian Press. May 5. 
Wyman, Bill. 2009. "Five Key Reasons Why Newspapers Are Failing ... and Why They Don't Get Talked About Much." Splice Today. Aug. 12.

Yardley, William, and Pérez-Peña, Richard. 2009. "Seattle Paper Shifts Entirely to the Web. New York Times. March 17.

Yew, Madhavi Acharya-Tom. 2012. "Torstar Corp. Profits Rise in Q4." Toronto Star. Feb. 29.

YouTube. 2010. "'Newsday Commercial: iPad Is Not a Paper." www.youtube.. m $/$ watch?v=Rtdq87nX6EA\&feature=related. Posted Nov. 29. Accessed July 21, 2012. 